
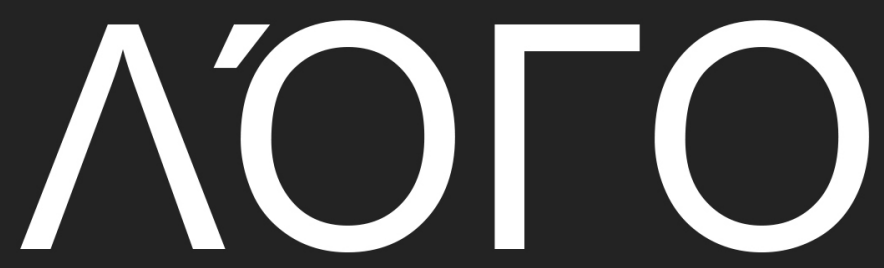

COLLECTION DE PAPIERS SCIENTIFIQUES

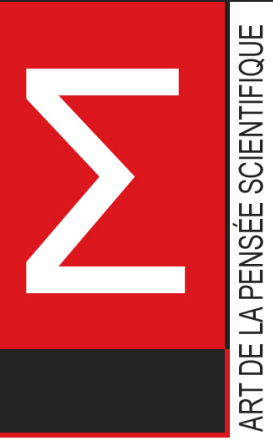

SUR LES MATÉRIAUX DE LA CONFÉRENCE SCIENTIFIQUE ET PRATIQUE INTERNATIONALE

PROBLĖMES ET PERSPECTIVES D'INTRODUCTION DE LA RECHERCHE SCIENTIFIQUE INNOVANTE 29 NOVEMBRE 2019 • BRUXELLES, BELGIQUE

\title{
VOLUME 2
}

DOI 10.36074/29.11.2019.v2

ISBN 978-617-7171-89-7

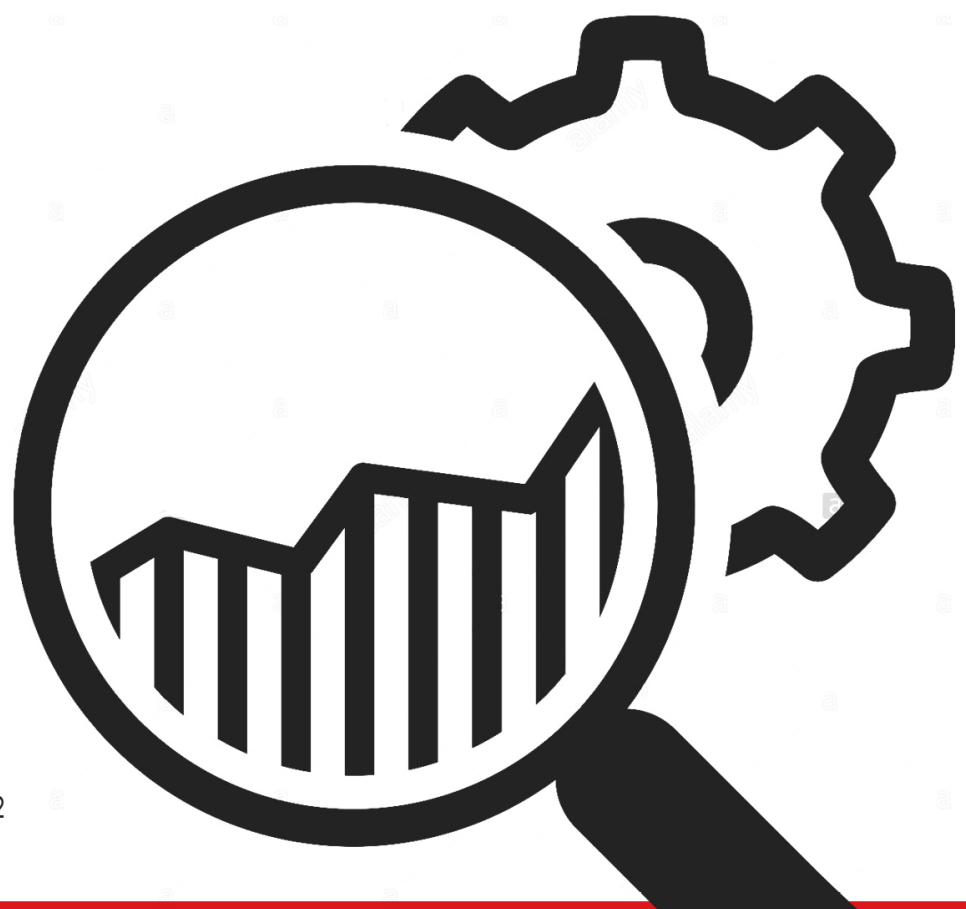



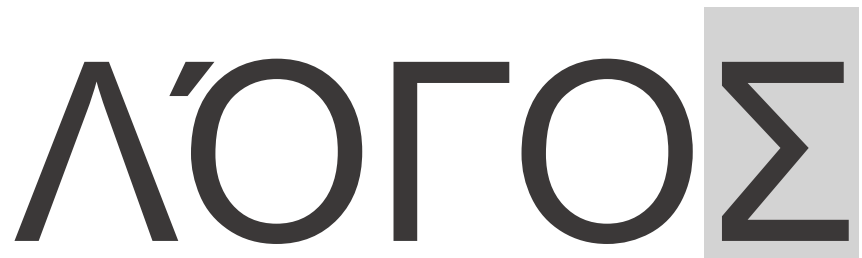

COLLECTION DE PAPIERS SCIENTIFIQUES

SUR LES MATÉRIAUX DE LA CONFÉRENCE SCIENTIFIQUE ET PRATIQUE INTERNATIONALE

«PROBLÈMES ET PERSPECTIVES D'INTRODUCTION DE LA RECHERCHE SCIENTIFIQUE INNOVANTE»

29 NOVEMBRE 2019

VOLUME 2

Bruxelles • Belgique 
P 93

Président du comité d'organisation: Holdenblat M.

Responsable de la mise en page: Kazmina $N$.

Responsable de la conception: Bondarenko I.

P 93 Problèmes et perspectives d'introduction de la recherche scientifique innovante: collection de papiers scientifiques

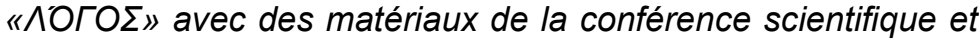
pratique internationale (Vol. 2), 29 novembre, 2019. Bruxelles, Belgique: Plateforme scientifique européenne.

ISBN 978-617-7171-89-7

DOI 10.36074/29.11.2019.v2

Les résumés et articles des participants à la conférence multidisciplinaire scientifique et pratique internationale «Problèmes et perspectives d'introduction de la recherche scientifique innovante», qui s'est tenue à Bruxelles le 29 novembre 2019, sont présentés.

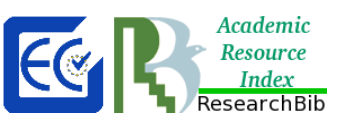

L'événement est inclus dans le catalogue des conférences scientifiques internationales, approuvé sur la plate-forme ResearchBib et certifié par Euro Science Certification Group norme scientifique SCC-2000.

Les documents de la conférence sont disponibles au public sous licence Creative Commons Attribution 4.0 International (CC BY 4.0).

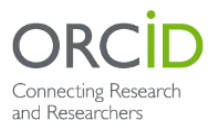

and Researchers

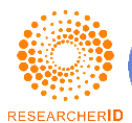

RESEARCHERID
La description bibliographique des documents de la conférence peut être téléchargée et indexée dans ORCID, Publons, Google Scholar, etc. 


\section{CONTENU}

\section{SECTION I. SCIENCES ECONOMIQUES}

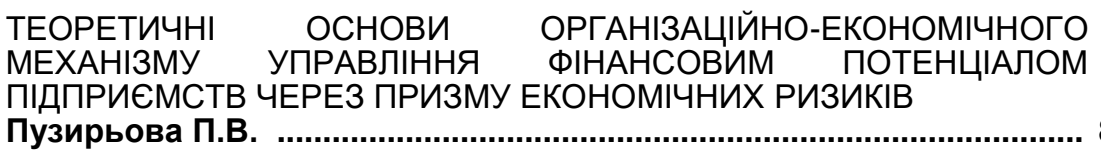

УПРАВЛІНСЬКА ЗВІТНІСТЬ ЩОДО ВИТРАТ ТРАНСПОРТНОГО ПІДПРИЄМСТВА

Мосійчук О.М.

ФІНАНСОВИЙ ПОТЕНЦІАЛ СІЛЬСЬКОГОСПОДАРСЬКИХ ПІДПРИЕМСТВ ЯК ІНДИКАТОР ЇХ СПРОМОЖНОСТІ НА РИНКУ ЗЕМЛІ

Рудик В.К., Федчишина М.В.

ФОРМУВАННЯ СИСТЕМИ ЛОГІСТИКИ ЯК УМОВА ПІДВИЩЕННЯ ЕФЕКТИВНОСТІ ДІЯЛЬНОСТІ ПІДПРИЕМСТВ ТОРГІВЛІ

Поповський О.Ю.

ЩО З ОПОДАТКУВАННЯМ РЕКЛАМ СПЛАЧЕНИХ У СОЦМЕРЕЖАХ? Омельчак В.Д.

\section{SECTION II. SCIENCES AGRICOLES}

EFFICIENCY OF USE OF LAND RESOURCES OF THE ENTERPRISE USING THE EXAMPLE OF THE FERGANA REGION

Marupov A.

LE DEVELOPPEMENT DE LA TECHNOLOGIE DE L'UTILISATION DES DECHETS DE L'INDUSTRIE BRASSICOLE AVEC LA PRODUCTION DES SAUCISSES DIETETIQUES «HAMBIR»

Research group:

Gornitch E., Soldatkina N., Kudriachov E., Gbangho G.

АКТИВНІСТЬ ФЕРМЕНТУ КАТАЛАЗА ЧОРНОЗЕМІВ ТИПОВИХ ЗА РІЗНИХ СИСТЕМ ЗЕМЛЕРОБСТВА

Рєзнік С.В., Гавва Д.В.

ПОЖИВНІСТЬ ЗЕЛЕНОЇ МАСИ РІЗНИХ СОРТІВ КОНЮШИНИ

Вихопень Ю.Б., Павкович С.Я.

ПРОДОЛЖИТЕЛЬНОСТЬ СЕРВИС-ПЕРИОДА И ИНДИФФЕРЕНС- 
4 - Problèmes et perspectives d'introduction de la recherche scientifique innovante $\bullet$ Volume 2

ПЕРИОДА У КОРОВ РАЗНЫХ ГЕНОТИПОВ В УСЛОВИЯХ МОСКОВСКОЙ ОБЛАСТИ

Мухтарова О.М., Бакай А.В.

СЕЛЕКЦІЙНА ОЦІНКА РІЗНИХ ГЕНОТИПІВ ПРИ НОВОЇ ПОПУЛЯЦІЇ МЯСНИХ СИМЕНТАЛІВ ЖУЙНИХ У ЗОНІ УКРАЇНСЬКИХ КАРПАТ

Калинка А.К.

SECTION III.

ADMINISTRATION PUBLIQUE ET ENVIRONNEMENT

APPRECIATING ECOLOGICAL DANGEROUS OF MUNICIPAL SOLID WASTE USING POLYNOMIAL APPROXIMATION

Lapyga I.

ЗАСТОСУВАННЯ КОНЦЕПЦІЇ МІЖОРГАНІЗАЦІЙНОЇ СУМІСНОСТІ І ВЗАЄМОДІЇ В ІНФОРМАЦІЙНИХ СИСТЕМАХ ОРГАНІВ ПУБЛІЧНОГО УПРАВЛІННЯ У КОНТЕКСТІ ДОСВІДУ ШВЕЦІЇ

Андрієнко А.О.

СПІНДОКТЕРІНГ - СУЧАСНА ТЕХНОЛОГІЯ В ДЕРЖАВНОМУ УПРАВЛІННІ

Адамовська В.С., Карпутенко А.І.

ТЕОРЕТИЧНІ АСПЕКТИ РЕАЛІЗАЦІЇ ІННОВАЦІЙНОЇ МОДЕЛІ УПРАВЛІННЯ ЗАКЛАДОМ ВИЩОЇ ОСВІТИ

Соколова Е.Т.

ТЕРИТОРІАЛЬНА ГРОМАДА ЯК ПЕРВИННИЙ СУБ'ЄКТ МІСЦЕВОГО САМОВРЯДУВАННЯ: СУТНІСТЬ ТА ФУНКЦІЇ

Архипенко С.В., Почужевська Ю.Л.

УДОСКОНАЛЕННЯ УПРАВЛІННЯ ПЕРСОНАЛОМ У ОРГАНАХ МІСЦЕВОГО САМОВРЯДУВАННЯ

Семеняка Т.В.

ЦИФРИЗАЦІЯ ВІДНОСИН ВЛАДИ, БІЗНЕСУ ТА ОСВІТИ В УКРАЇНІ Науково-дослідна група:

Адамовська В.С., Архипенко С.В., Голобородько Т.В., Ярова А.Б., Родіонов В.Д., Манелюк Д.А.

SECTION III. SCIENCES TECHNIQUES ET TI

ABOUT MIXING A LIQUID METAL OF A WELDING POOL IN ARC SURFACING WITH A TRANSVERSE MAGNETIC FIELD EFFECT Ahieieva M., Razmyshlyaev A. 
APPLICATIONS OF THE KALMAN FILTER TO NAVIGATION DATA Kereyev A.

COLMATANT AS MATERIAL FOR PREVENTION AND LIQUIDATION ABSORPTION OF DRILLING FLUIDS

Research group:

Diachenko Yu., Osheiko S., Kalnytskyi, N.

DEVELOPMENT OF AN OPTIMAL AIRCRAFT CONTROL SYSTEM

Research group:

Kutzhanova D., Amirzhanova Z., Satybaldina D.

DEVELOPMENT OF UNMANNED AERIAL VEHICLE CONTROL SYSTEM

Research group:

Uashov Ye., Mashtayeva A., Satybaldina D.

EFFICIENCY OF APPLICATION OF DRILLING FLUIDS WITH HIGH LUBRICATING PROPERTIES FOR DRILLING DIRECTIONAL AND HORIZONTAL WELLS

Dmytrenko V., Diachenko Yu.

FEATURES OF STRESS-STRAIN STATE MODELING OF PIPELINES WITH GAS-LIQUID CHEMICALLY ACTIVE MIXTURES

Research group:

Oliinyk A., Nezamay B., Shalamai A.

HANDLING WITH CYBERCRIME

Pecheniuk 0.

MODELING OF THE WELD POOL FORMATION DURING SURFACING WITH STRIP ELECTRODE

Ivanov V., Lavrova E.

MODERN POTENTIAL AND ECONOMIC OPPORTUNITIES OF MANAGING ALTERNATIVE ENERGY SOURCES

Kustov A.

NODEMCU ЯК ПЛАТФОРМА ДЛЯ РОЗУМНОГО БУДИНКУ

Лicorip Ю.М.

OUTLOOK «GREENING» OF HYDRAULIC FRACKING TECHNOLOGY FOR THE PRODUCTION OF UNCONVENTIONAL HYDROCARBONS Oveckiy S.

PREREQUISITES OF THE VALUE-ENTROPY APPROACH TO PROJECT ORGANIZATION MANAGEMENT

Bondar A. 91

PROSPECTS FOR THE USE DRY PLANT MILK IN THE PRODUCTION 
6 - Problèmes et perspectives d'introduction de la recherche scientifique innovante $\bullet$ Volume 2

OF DESSERTS

Research group:

Maletskyi M., Nalyvaiko A., Handuchka A., Suprunenko K.

THE LEAN MANUFACTURING SYSTEM AS A CONCEPT OF ENTERPRISE MANAGEMENT

Zotova, H., Krytsky V.

THE METHOD OF THE UNMANNED AERIAL VEHICLES DETECTION IN MULTIRADAR SYSTEM BASED ON SURVEILLANCE RADARS

Research group:

Lishchenko V., Kravchenko I., Lukianchykov A., Hnyria V.

АВТОМАТИЗАЦИЯ ТЕСТИРОВАНИЯ ПРОГРАММНЫХ СИСТЕМ

Денисенко А.А.

АВТОМАТИЗОВАНИЙ СИНТЕЗ СТРУКТУР ЗГОРТКОВИХ НЕЙРОННИХ МЕРЕЖ

Лящинський П.Б., Лящинський П.Б.

АНАЛІЗ СТРУКТУРИ ІНФОРМАЦЙНОЇ СИСТЕМ ПОШУКУ ТА ВИЛУЧЕННЯ ФАКТІВ 3 ІНТЕРНЕТ-ВІДГУКІВ ПРО ТОВАР

Науково-дослідна група:

Бабкова Н.В., Яковенко К.В., Хазієв А.В.

БІОЛОГІЧНО ЦННІСТЬ ШВИДКОЗАМОРОЖЕНОГО ДЕСЕРТУ ФУНКЦІОНАЛЬНОГО ПРИЗНАЧЕННЯ З ВИКОРИСТАННЯМ ХУРМИ Науково-дослідна група:

Заболотна А.В., Заболотний О.І., Пиркало В.В.

ВАЖНОСТЬ СИСТЕМЫ МЕНЕДЖМЕНТА КАЧЕСТВА И ЕЕ ВЛИЯНИЕ НА КАЧЕСТВО ПРОДУКЦИИ НА ПРЕДПРИЯТИЯХ РЕСПУБЛИКИ КАЗАХСТАН

Амренова А.Б., Тайманова Г.К.

ВИЗНАЧЕННЯ ФІЗИЧНИХ ХАРАКТЕРИСТИК ОПЕРАЦІІ ОБРОБЛЕННЯ СВЕРДЛІННЯМ

Біланенко В.Г.

ВИКОРИСТАННЯ ГЕНЕТИЧНИХ АЛГОРИТМІВ У МАШИННОМУ НАВЧАННI

Тимофеєва A.€.

ДОСВІД ВИКОРИСТАННЯ МОБІЛЬНИХ ТЕЛЕФОНІВ ПРИ ВИКЛАДАННІ ТЕХНІЧНОЇ МЕХАНІКИ

Мікаілова М.Л.

ДЕРЕВО ВІДМОВ - ІНСТРУМЕНТАРІЙ ОЦІНЮВАННЯ НАДІЙНОСТІ ТЕХНОЛОГІЧНИХ СИСТЕМ

Рубанніков М.A. 
ЗНЕШУМЛЕННЯ СУПУТНИКОВИХ ЗНІМКІВ ІЗ ВИКОРИСТАННЯ ІНТЕРПОЛЯЦІї ЛАНЧОСА

Шиш М.М.

ІННОВАЦІЙНІ ТЕНДЕНЦІЇ РОЗВИТКУ УСТАТКУВАННЯ В ЗАКЛАДАХ ГОТЕЛЬНО-РЕСТОРАННОГО ГОСПОДАРСТВА

Будженко А.Ю., Іваніщева О.А.

МОДЕЛИРОВАНИЕ РАБОТЫ ШПАНГОУТНОЙ ВАННЫ С ДОПОЛНИТЕЛЬНЫМ ТЕПЛОИЗОЛЯТОРОМ Мелешко И.А., Назарова Е.С. 


\section{SECTION I. SCIENCES ECONOMIQUES}

DOI 10.36074/29.11.2019.v2.01

\section{ТЕОРЕТИЧНІ ОСНОВИ ОРГАНІЗАЦІЙНО-ЕКОНОМІЧНОГО МЕХАНІЗМУ УПРАВЛІННЯ ФІНАНСОВИМ ПОТЕНЦІАЛОМ ПІДПРИЄМСТВ ЧЕРЕЗ ПРИЗМУ ЕКОНОМІЧНИХ РИЗИКІВ}

Пузирьова Поліна Володимирівна

кандидат економічних наук, доцент, доцент кафедри підприємництва та бізнесу Київський національний університет технологій та дизайну

УКРАÏHA

В сучасних умовах господарювання діяльність кожного підприємства, організації або установи спрямована на досягнення бажаних позитивних результатів, зокрема фрінансових, з урахуванням виникнення ризикових ситуацій. Ефективність діяльності та результативність підприємства визначається вихідними умовами і раціональною управлінською орієнтацією щодо їх управління [1-2, 8].

Організаційно-економічний механізм управління фінансовим потенціалом через призму економічних ризиків - це поетапний процес впливу на фінансовий потенціал 3 мінімізацією можливих збитків, уникненням можливостей недоотримання прибутку, врахуванням ступеня впливу ризику на утримання конкурентних позицій на ринку для збереження його стійкості або переходу з одного стану в інший відповідно до цілей та мети підприємства [1011]. Рівень наявного у підприємства фрінансового потенціалу визначається обсягом та якістю накопичених фрінансових ресурсів (стану активів, рівня ліквідності, можливостей та обсягів залучення кредитів). Потенційні можливості підприємства при ефективному використанні фінансових ресурсів з урахуванням можливих економічних ризиків визначають стратегічний потенціал підприємства, який залежить від низки факторів $[8,10]$.

Система стратегічного управління фрінансовим потенціалом підприємства при врахуванні економічних ризиків - це комплексна взаємопов'язана структура управління, спрямована на розробку загальних і довгострокових стратегічних фінансових завдань підприємства, заходів запобігання ризику [34], програм дій, орієнтованих на перспективу, в межах яких досягається виконання головної мети підприємства - забезпечення міцного фрінансового потенціалу підприємства й утримання його стійких позицій в конкурентному середовищі [11]. У процесі реалізації організаційно-економічного механізму управління фінансовим потенціалом підприємства під впливом економічних ризиків том-менеджмент повинен здійснювати наступні дії [5-7]:

- створювати сприятливих умови діяльності підприємства, які дозволять здійснити реалізацію стратегії, розробку стилю стратегічного управління та заходи з мінімізації можливих економічних ризиків;

- створювати корпоративну культуру, що допоможе в реалізації стратегії, наявності коштів, які забезпечують реалізацію стратегії та оцінку впливу факторів ризику на підприємство; 
- розвивати інформаційну та контролюючу системи, які допоможуть управляти фінансовим потенціалом підприємства та оптимізувати вірогідність виникнення ризиків.

Організаційно-економічний механізм управління фінансовим потенціалом підприємства під впливом економічних ризиків - це сукупність певних стратегій, методів і прийомів, цілей та засобів, які використовуються щодо управління фінансовим потенціалом підприємства з мінімізацією його ризиків $[9,10]$. Роботу з ризик-менеджменту на підприємстві доцільно здійснювати за допомогою спеціально розробленої програми управління ризиками. Для розробки такої програми і контролю за її виконанням має бути створений спеціальний підрозділ, очолюваний ризик-менеджером, в обов'язки якого мають входити всі питання щодо реалізації програми управління ризиками і розробки відповідного положення про управління ризиками підприємства. Положення має відображати фрілософію підприємства щодо управління ризиками, розмежовувати його між різними структурними одиницями. При цьому основна мета ризик-менеджменту підприємства - це забезпечення оптимального для акціонерів підприємства й інвесторів балансу між максимізацією прибутку і довгостроковою стабільністю діяльності підприємства. Для досягнення цієї мети основою системи управління ризиками повинні бути принципи комплексності, безперервності та інтеграції [11-14].

Отже, організаційно-економічний механізм управління фінансовим потенціалом підприємств через призму економічних ризиків - це поняття комплексне та багатоелементне, яке впливає на управління фінансовим потенціалом в цілому, і впливає на невизначеність і ступінь впливу факторів економічного ризику, які поділені за мінімальним, середнім і високим рівнем у процесі оцінки фінансового потенціалу підприємств. При цьому особливого значення набуває керуюча та виконавча частини забезпечення управління фінансовим потенціалом підприємств, де значну увагу приділено ризикменеджменту, який повинен розробити програму управління та контролю економічних ризиків за допомогою спеціально створеного підрозділу, очолюваного ризик-менеджером.

\section{Список використаних джерел:}

1. Боронос, В.Г. (2012). Фінансовий потенціал території у державній фінансовій політиці: методологія і практика управління (дисертація... дра. економ. наук). ДВНЗ "УАБС НБУ". Суми, Україна.

2. Буряченко, А.Є. (2016). Економічна природа фінансового потенціалу регіону. Наукові записки Національного університету "Острозька академія". Серія "Економіка", 3 (31), 96102.

3. Вітлінський, В.В., Великоіваненко, Г.І. (2004). Ризикологія в економіці та підприємництві. К. : Національний економічний університет.

4. Денисюк, О.Г. (2010). Майновий потенціал підприємства: сутність, відтворення, управління. УНДІ продуктивності АПК.

5. Домбровська, С. О. (2016). Вплив фінансового ризику на систему управління фінансовими ресурсами підприємства. Вісник соціально-економічних досліджень. 2 (61).

6. Зайчук, Т. О. (2012). Теоретичні аспекти визначення ринкового потенціалу і таргетингу вітчизняними підприємствами. Маркетинг і менеджмент інновацій. (1), 96-104.

7. Касьянова, Н. В. (2013). Потенціал підприємства: формування та використання. Київ: «Центр учбової літератури». 
10 - Problèmes et perspectives d'introduction de la recherche scientifique innovante $\bullet$ Volume 2

8. Комарецька, П. В. (2003). Теоретичні підходи щодо сутності фінансового потенціалу. Вестник Харьковского национального университета им. В.Н.Каразина "Национализация и приватизация: прошлое, настоящее, будущее”: Экономическая серия, (613), 236-241.

9. Маслак, О.І. (2013). Особливості оцінювання економічного потенціалу підприємства в умовах циклічних коливань. Вісник соціально-економічних досліджень. Вип. (1), 121-127.

10. Пузирьова, П.В.(2010). Базові методи нейтралізації фінансових ризиків у підприємницькій діяльності. Актуальні проблеми економіки. 5 (107), С.143-149.

11. Пузирьова, П. В. (2008). Оцінка економічного ризику в управлінні фінансовим потенціалом промислових підприємств України. Формування ринкових відносин в України. (10), С. 131134.

12. Свірський, В.С. (2012). Фінансовий потенціал економічного зростання в Україні: дис. на здобуття наук. ступеня канд. екон. наук: спец. 08.00 .08 гроші, фрінанси і кредит / В.С. Свірський. Тернопіль: ТНЕУ, 277 с.

13. Турчак, В. В. (2014). Методика оцінки фінансового потенціалу підприємства в сучасних умовах господарювання. Молодий вчений. 8 (11), С. 49-52.

14. Tkachenko, V., Kwilinski, A., Tkachenko, I., \& Puzyrova, P. (2019). Development and effectiveness of financial potential management of enterprises in modern conditions. Financial and credit activity: problems of theory and practice. http://fkd.org.ua/article/view/179513/180295.

\section{УПРАВЛІНСЬКА ЗВІТНІСТЬ ЩОДО ВИТРАТ ТРАНСПОРТНОГО ПІДПРИЄМСТВА}

\section{Мосійчук Ольга Миколаївна}

здобувач вищої освіти інституту економіки та менеджменту

Національний університет водного господарства та природокористування

Науковий керівник: Осадча Ольга Олексіївна

д-р. екон. наук, професор, доцент кафедри обліку і аудит

Національний університет водного господарства та природокористування

УКРАÏHA

Використання управлінської звітності щодо витрат актуально в умовах сучасного стану економіки, коли при ринковій конкуренції транспортні підприємства прагнуть мінімізувати витрати і збільшити ефективність діяльності, а через неправильно організований управлінський облік знижується ефективність прийнятих рішень, що відповідно позначається на показниках роботи підприємства. Саме тому проблема своєчасності і точності надання управлінської звітності щодо витрат та ефективного її використання в сучасних умовах набуває важливого значення.

Важливим етапом побудови управлінської звітності $є$ створення системи отримання оперативної, точної і достовірної інформації про функціонування підприємства в цілому і його структурних підрозділів, що дозволяє приймати своєчасні та ефективні управлінські рішення. Внаслідок різних потреб, що виникають у керівників, управлінська звітність щодо витрат транспортного підприємства має свою специфріку. Для формування такої звітності перш за все необхідно затвердити форму звітності, вибір якої безпосередньо впливатиме на кінцеву оцінку результатів діяльності підприємства. Від інформативності 
управлінської звітності щодо витрат залежить якість адміністративних рішень, які приймає керівництво підприємства, їх доцільність та ефективність. Тому в звітності повинні бути зазначені дані про показники, які наочно характеризують діяльність кожного підрозділу за певний період часу. В управлінських цілях важливими індикаторами ефективності процесів, що відбуваються $\epsilon$ інформація про оцінку рентабельності ресурсів в рамках конкретних підрозділів, а також порівняння цих даних за різні часові проміжки, що дозволить акцентувати увагу керівників на динаміці змін внутрішньо корпоративної ефективності.

За результатами дослідження практичного досвіду транспортних підприємств необхідно узагальнити процедуру розроблення внутрішньої управлінської звітності щодо витрат, яка включає низку послідовних етапів:

- виявити місця виникнення витрат підприємства з урахуванням специфіки господарської діяльності структурних підрозділів;

- розробити номенклатуру статей витрат підприємства, узгодити номенклатуру за сфрерами відповідальності;

- сформувати номенклатуру готової продукції та послуг, розподілити їх за сферами відповідальності;

- сформувати альбом внутрішніх звітів, необхідних для управління;

- розробити та затвердити періодичність подання внутрішніх звітів у розрізі видів звітів та сфер відповідальності, а також шифри за кожною сферою відповідальності із зазначенням відповідальної особи [1].

Ватро зазначити, що склад внутрішніх звітів залежить від потреб управління, особливостей розподілу відповідальності та діяльності підприємства. Розробка системи управлінської звітності щодо витрат залежить від багатьох чинників: від масштабів підприємства, потреб внутрішніх і зовнішніх користувачів, видів діяльності, організаційної структури, структури обліково-аналітичної системи, а найголовніше, від наявності тих видів звітності, які транспортне підприємство складає відповідно до законодавства (фрінансова, податкова і статистична звітність) і внутрішніми потребами (поточна і оперативна). Управлінська звітність акумулює в собі інформацію всіх видів звітності, що складаються на транспортному підприємстві, тобто це синтез внутрішніх і зовнішніх звітів, фрінансової та не фінансової інформації.

Незважаючи на те, що і фрінансова, і управлінська звітність $€$ інфрормаційним забезпеченням прийняття рішень, між ними існує суттєва різниця управлінська звітність має чітку адресність у межах підприємства й повинна надавати не загальну інформацію в довільному форматі, а інформацію, визначену внутрішніми регламентами, орієнтованими на конкретного користувача з визначеними цими регламентами показниками і форматом подання. Тобто складання управлінської звітності щодо витрат регламентується внутрішніми документами на підприємстві, і подається внутрішнім користувачам з певною метою.

Основне призначення управлінської звітності щодо витрат полягає в поданні показників про минулу і теперішню діяльності підприємства та використанні даних звітності для визначення параметрів майбутньої діяльності. При фрормуванні управлінської звітності використовується обліково-аналітичний підхід, який передбачає використання даних оперативного обліку, регламентованого фрінансового обліку, а також аналітичних показників, отриманих в ході обробки облікової інформації на 
основі застосування методів економічного аналізу. При веденні на підприємстві також управлінського обліку процедура складання управлінської звітності щодо витрат залежить від взаємозв'язку фрінансово-управлінської бухгалтерії.

При автономному варіанті організації показники управлінської звітності щодо витрат формуються на основі інформації управлінського обліку. При інтегрованому варіанті - управлінська звітність щодо витрат складається на взаємопов'язаних показниках фрінансового та управлінського обліку. На більшості транспортних підприємств звітність для цілей внутрішнього користування складається на основі інформації фрінансового обліку, ідентифікованої під потреби фрормування обліково-аналітичної інформації управлінської звітності.

Залежно від інформаційної бази управлінської звітності визначаються процедури побудови управлінської звітності щодо витрат та методична основа формування її показників. У разі, коли на підприємстві ведеться управлінський облік відокремлено від фінансового, при складанні управлінської звітності щодо витрат використовуються дані первинних облікових документів, які $\epsilon$ підставою здійснення тих чи інших господарських операцій на підприємстві. Цей підхід практично виключає використання інформації фінансового обліку.

Складання управлінської звітності щодо витрат на основі використання інформації фрінансово-управлінської бухгалтерії є найбільш доцільним з позиції економічного процесу фрормування інформації, що забезпечує оптимізацію інфрормаційних потоків всередині підприємства і зниження витрат на отримання показників управлінської звітності.

Третій формат управлінської звітності щодо витрат передбачає лише перегрупування показників фінансової звітності 3 метою підвищення аналітичності облікової інформації. При такому підході складання управлінської звітності щодо витрат використовуються аналітичні методи обробки даних фінансового обліку, що дозволяють здійснити перетворення фінансової звітності в формат управлінської звітності. Використання того чи іншого підходу при складанні управлінської звітності щодо витрат кожне транспортне підприємство вибирає самостійно залежно від рівня розвитку управлінського обліку і взаємодії фінансової та управлінської бухгалтерії.

Окремої уваги заслуговує проблема удосконалення управлінської звітності щодо витрат. Вона має кілька аспектів:

- розвиток теоретичних основ управлінської звітності щодо витрат, формування ії концепції, взаємозв'язків з іншими видами звітності та створення для них єдиної інформаційної бази;

- визначення форм і змісту управлінських звітів щодо витрат;

- удосконалення методики, алгоритму і техніки складання;

- уточнення організаційних засад (нормативного регулювання, порядку і строків підготовки, передачі користувачам);

- розробка та запровадження у практику сучасного програмного забезпечення для автоматизації процесу формування управлінської звітності щодо витрат та формалізації її показників [2].

Реалізація зазначених напрямів удосконалення і розвитку управлінської звітності щодо витрат має здійснюватись із урахуванням того, що на відміну від фінансового обліку і звітності (який безперервно збирає інфрормацію про всі об'єкти обліку), у системі управлінського обліку збирається і обробляється 
тільки та інформація, яка необхідна для складання конкретних форм звітності відповідно до вимог користувачів [3].

Внутрішня управлінська звітність щодо витрат, яка фрормується відповідно до внутрішніх регламентів, може містити інформацію, орієнтовану на зовнішніх користувачів. Залежно від структури обліково-аналітичної системи підприємства основою для формування внутрішньої управлінської звітності щодо витрат може виступати зовнішня фінансова звітність, а на деяких підприємствах цей вид звітності може використовуватися для прийняття рішень.

Висновки. Управлінська звітність щодо витрат на транспортних підприємствах має важливе значення, оскільки за її допомогою управлінський персонал отримує інформацію, яку не можна отримати з інших видів звітності. Розробка та формування такої звітності - це важливе рішення керівника, яке у майбутньому допоможе йому не просто витримати конкуренцію, але й збільшувати прибуток підприємства за рахунок налагодженої роботи всіх підрозділів і прискорення прийняття рішення на всіх рівнях.

\section{Список використаних джерел:}

1. Скрипник, М. І. \& Григоревська, О.О. (2016). Бухгалтерська управлінська звітність: критичний аналіз порядку складання й особливостей практичного застосування. Інтелект $X X I,(5), 111-115$.

2. Петрик, О. А. (2016). Управлінська фінансова та нефінансова звітність підприємств: концептуальний підхід та організаційні аспекти їі підготовки. Економіка, фрінанси, право, (3), 4-6.

3. Король, С. Я. (2014). Управлінська звітність: сутність і алгоритм формування. Бізнес-інформ, (7), 325-331.

\section{ФІНАНСОВИЙ ПОТЕНЦІАЛ СІЛЬСЬКОГОСПОДАРСЬКИХ ПІДПРИЕМСТВ ЯК ІНДИКАТОР ЇХ СПРОМОЖНОСТІ НА РИНКУ ЗЕМЛІ}

Рудик Володимир Касянович
д-р. екон. наук, доцент, професор кафедри фрінансів, банківської справи, страхування та електронних платіжних систем Подільський державний аграрно-технічний університет Федчишина Маргарита Вікторівна
здобувач вищої освіти економічного факультету
Подільський державний аграрно-технічний університет
УКРАїНА

У сучасній концепції соціально-економічного розвитку України поставлені принципово нові завдання досягнення передового технологічного укладу, що забезпечить стійкі темпи росту валового внутрішнього продукту. Однією 3 передумов виконання цих завдань вважається скасування мораторію на продаж сільськогосподарських земель. Водночас при цьому постає проблема 
недосконалості ринкових механізмів; зокрема, на перший план висувається пошук фінансових ресурсів на операції, пов'язані із купівлею землі. Тому дане дослідження спрямоване на з'ясування проблем у використанні фінансового потенціалу підприємств аграрної сфери.

Фінансовий потенціал галузі зумовлений тими ресурсами, які $\epsilon$ у розпорядженні підприємств та забезпечують їх конкурентоздатність. Динаміка джерел фінансування аграрних підприємств представлена у таблицях 1 та 2. Дані таблиць свідчать, що упродовж 2015 р. та 2016 р. джерела фінансування зростали високими темпами, а на кінець 2017 р. відбулось їх стрімке скорочення і вони склали проти 2016 р. лише 59,3\%. 2018 року знову спостерігалось збільшення фінансових джерел, які в цілому перевищили базисний рік у 2,5 рази.

У складі джерел фрінансового забезпечення стійкі темпи зростання характерні для власного капіталу, який 2018 року збільшився майже втричі порівняно із 2014 роком, проте слід відмітити суттєвий спад темпів його росту впродовж останніх двох років. Позитивним явищем 2018 р. є зростання довгострокових зобов'язань; короткострокові пасиви залишились майже на рівні попереднього року.

Таблиця 1

Основні показники джерел фінансування аграрних підприємств України*

\begin{tabular}{|l|c|c|c|c|c|}
\hline \multicolumn{1}{|c|}{ Показники } & \multicolumn{5}{|c|}{ на 31 грудня } \\
\cline { 2 - 6 } & 2014 р. & 2015 р. & 2016 р. & 2017 р. & 2018 р. \\
\hline Власний капітал, млн. грн. & 163931,7 & 275303,8 & 369370,9 & 436337,7 & 482978,7 \\
\hline $\begin{array}{l}\text { Довгострокові зобов'язання і } \\
\text { забезпечення, млн. грн. }\end{array}$ & 62975,4 & 68127,2 & 61898,2 & 59080,5 & 82253,9 \\
\hline $\begin{array}{l}\text { Поточні зобов'язання і } \\
\text { забезпечення }\end{array}$ & 163616,6 & 342359,0 & 1105991,9 & 416146,2 & 418283,2 \\
\hline $\begin{array}{l}\text { Зобов'язання з необоротних активів } \\
\text { та групами вибуття, млн. грн. }\end{array}$ & 83,3 & 54,9 & 58,1 & 49,7 & 77,8 \\
\hline Всього джерел, млн. грн. & 390607,0 & 685844,9 & 1537319,1 & 911614,1 & 983593,6 \\
\hline $\begin{array}{l}\text { Валовий внутрішній продукт у } \\
\text { фактичних цінах, млн. грн. }\end{array}$ & 161145,0 & 239806,0 & 279701,0 & 303949,0 & 360757,0 \\
\hline $\begin{array}{l}\text { Співвідношення власного капіталу } \\
\text { та ВВП, \% }\end{array}$ & 101,7 & 114,8 & 132,1 & 143,6 & 133,9 \\
\hline Чистий прибуток, млн. грн. & 21481,3 & 102849,1 & 90613,2 & 68858,5 & 71002,6 \\
\hline Рентабельність чистих активів, \% & 13,1 & 37,4 & 24,5 & 15,8 & 14,7 \\
\hline
\end{tabular}

Динаміка основних показників фінансування*

Таблиця 2

\begin{tabular}{|l|c|c|c|c|c|}
\hline \multirow{2}{*}{ Показники } & \multicolumn{5}{|c|}{ Темп приросту } \\
\cline { 2 - 6 } & $\begin{array}{c}2015- \\
2014 \text { pp. }\end{array}$ & $\begin{array}{c}2016- \\
2015 \text { pp. }\end{array}$ & $\begin{array}{c}2017- \\
2016 \text { pp. }\end{array}$ & $\begin{array}{c}2018- \\
2017 \text { pp. }\end{array}$ & $\begin{array}{c}2018- \\
2014 \text { pp. }\end{array}$ \\
\hline Власний капітал & 167,9 & 134,2 & 118,1 & 110,7 & 294,6 \\
\hline $\begin{array}{l}\text { Довгострокові зобов'язання і } \\
\text { забезпечення }\end{array}$ & 108,2 & 90,9 & 95,4 & 139,2 & 130,6 \\
\hline $\begin{array}{l}\text { Поточні зобов'язання і } \\
\text { забезпечення }\end{array}$ & 209,2 & 323,1 & 37,6 & 100,5 & 255,6 \\
\hline $\begin{array}{l}\text { Зобов'язання з необоротних } \\
\text { активів та групами вибуття }\end{array}$ & 65,9 & 105,8 & 85,5 & 156,5 & 93,4 \\
\hline Всього джерел & 175,6 & 224,1 & 59,3 & 107,9 & 251,8 \\
\hline
\end{tabular}

Продовження табл. 1 


\begin{tabular}{|l|c|c|c|c|c|}
\hline \multirow{2}{*}{ Показники } & \multicolumn{5}{|c|}{ Темп приросту } \\
\cline { 2 - 6 } & $\begin{array}{c}2015- \\
2014 \text { pp. }\end{array}$ & $\begin{array}{c}2016- \\
2015 \text { pp. }\end{array}$ & $\begin{array}{c}2017- \\
2016 \text { pp. }\end{array}$ & $\begin{array}{c}2018- \\
2017 \text { pp. }\end{array}$ & $\begin{array}{c}2018- \\
2014 \text { pp. }\end{array}$ \\
\hline $\begin{array}{l}\text { Валовий внутрішній продукт у } \\
\text { фактичних цінах }\end{array}$ & 148,8 & 116,6 & 108,7 & 118,7 & 223,9 \\
\hline Чистий прибуток & 478,8 & 88,1 & 76,0 & 103,1 & 330,5 \\
\hline
\end{tabular}

Тенденції у динаміці джерел фрінансування зумовили їх структурні зміни (рис. 1). Високі ризики фрінансування наприкінці 2016 р. пояснюються тим, що активи сільськогосподарських підприємств на $72 \%$ були сформовані за рахунок короткострокових фрінансових джерел. Власний капітал становив лише $24 \%$.

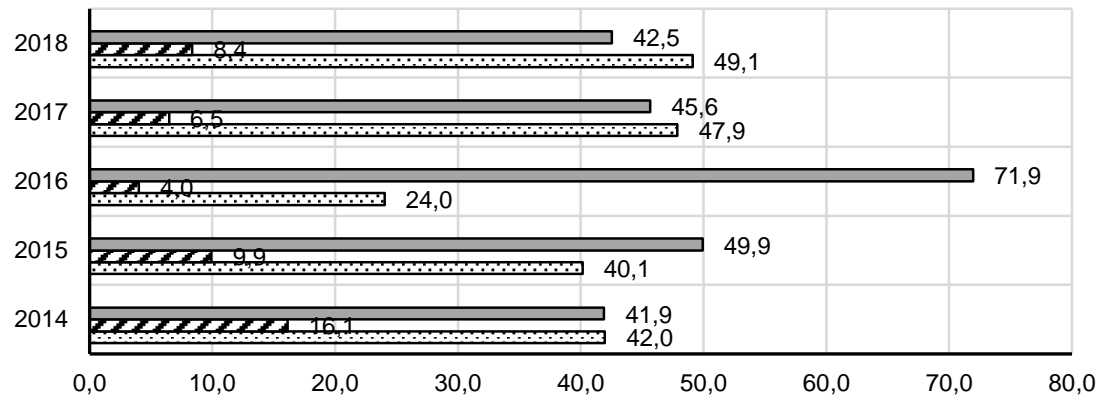

口Поточні зобовязання і забезпечення

ФДовгострокові зобовязання і забезпечення

๑Власний капітал

Рис. 1. Структура капіталу аграрних підприємств України* *Прим. Складено авторами за даними Держкомстату

Проте 2017 р. та 2018 р. структура пасивів значно покращилась, хоча власний капітал поки що не досягає $50 \%$ у фінансовому забезпеченні аграрної галузі. Отже, фрінансовий потенціал як стартова оцінка можливостей сільськогосподарських підприємств у найближчій перспективі не зможе забезпечити вивільнення власних обігових коштів для придбання земельних паїв у орендодавців. Досвід розвинених країн демонструє, що запровадження ринкового обігу земель сільськогосподарського призначення повинне підкріплюватись кредитними інструментами, доступними для всіх підприємств - потенційних покупців незалежно від їх розміру.

Проведений аналіз дає підстави для висновку, що фінансова модель аграрного сектору економіки є досить стійкою, свідченням чого є перевищення власного капіталу над номінальним валовим внутрішнім продуктом (див. табл. 1). Основним чинником зростання власного капіталу сільськогосподарських підприємств був нерозподілений прибуток. Незважаючи на те, що 2016-2017 рр. він зменшувався, 2018 року його зростання відновилось, що свідчить про зростання номінальної капіталізації і на думку Дж. Нітцана та Ш. Бічлера є однією з ознак посилення впливу капіталу 
на регулювання економіки [2]. Зауважимо, що за цим співвідношенням Україна наближається до рівня розвинених країн.

Висновки. Аналіз макроекономічних показників фрінансового забезпечення сільського господарства показав, що ця галузь має достатньо високий потенціал для використання сучасних кредитних інструментів, актуальність яких зростає у зв'язку із запровадженням ринку землі. Проте не всі підприємства знаходяться в однакових умовах доступу до фрінансових ресурсів, що потребує системної модернізації взаємодії аграрних товаровиробників із банками.

\section{Список використаних джерел:}

1. Державна служба статистики України. Вилучено з www.ukrstat.gov.ua.

2. Nitzan, J \& Bichler, Sh.(2009). Capital is power. A study of order and creorder. London and New York: Routledge, Taylor and Francis Group. ISBN 0-203-87632-6. Вилучено 3 http://bnarchives.yorku.ca/259/2/20090522_nb_casp_full_indexed.pdf

\section{ФОРМУВАННЯ СИСТЕМИ ЛОГІСТИКИ ЯК УМОВА ПІДВИЩЕННЯ ЕФЕКТИВНОСТІ ДІЯЛЬНОСТІ ПІДПРИЄМСТВ ТОРГІВЛІ}

Поповський Олег Юрійович

здобувач освітнього ступеня «магістр» факультету економіки, менеджменту та права Вінницький торговельно-економічний інститут КНТЕУ

УКPAÏHA

Одним із найважливіших аспектів діяльності торговельних підприємств в умовах ринкової економіки $є$ пошук необхідних товарних ресурсів і організація ефективної системи товаропостачання торговельних об'єктів. На жаль, у вітчизняній економічній літературі останнього десятиріччя ця проблема розглядається переважно у контексті загальної комерційної діяльності суб'єктів господарювання, а спеціальні дослідження окремих фрахівців не охоплюють всього кола проблем, зокрема питань формування ефективної системи збирання, зберігання, опрацювання та передавання інформації, необхідної для організації руху товарної маси до роздрібної торговельної мережі, для прийняття відповідних управлінських рішень та забезпечення якісного зв'язку між суб'єктами системи товаропостачання.

Взагалі питання змісту та організації логістичної діяльності в економіці були предметом розгляду в працях вітчизняних науковців (В. Апопій, Ю. Пономарьова, А. Мазаракі, Є. Крикавський, А. Кальченко, М. Окландер, Н. Чухрай, Ю. та ін.) і зарубіжних вчених (М. Крістофрер, Д. Сток, А. Гаджинський, Л. Міротін, В. Сергєєв та ін.).

Метою статті $€$ розвиток науково-теоретичних положень щодо організації логістичної діяльності підприємств торгівлі та розробка науково- практичних 
рекомендацій з фрормування систем логістики суб'єктів господарювання в окремих сегментах внутрішньої торгівлі.

Завданням статті є відображення результатів проведеного автором аналізу змісту організації логістичної діяльності підприємств торгівлі та дослідження особливостей, напрямів і проблем формування систем логістики в підприємствах торгівлі.

Товаропостачання роздрібної торговельної мережі - це комплекс комерційних і технологічних операцій, спрямованих на доведення товарів до роздрібної торговельної мережі в кількості та асортименті, що відповідають попиту населення.

Товаропостачання роздрібної торговельної мережі з погляду теорії систем потрібно розглядати як складну динамічну систему, яка має свою морфологічну та функціональну структуру, основною цільовою метою якої $€$ безперебійне доведення до роздрібної торговельної мережі товарів, необхідних для задоволення попиту населення. При цьому морфологічна структура даної системи формується сукупністю взаємозв'язаних і взаємодіючих між собою суб'єктів даної системи, якими $є$ джерела товаропостачання (і окремі постачальники товарів), транспортні підприємства й організації (перевізники товарів, які забезпечують просторове переміщування товарів у процесі товаропостачання) і роздрібні торговельні підприємства, які є кінцевими пунктами завезення товарної маси (яка виступає як основний об'єкт системи товаропостачання).

На організацію товаропостачання впливають об'єктивні і суб'єктивні фактори. Фактори ,які впливають на організацію товаропостачання роздрібної торговельної мережі :

1.Рівень організації торгово - оперативних і технологічних процесів.

2.Чисельність, склад ,розташування роздрібної торговельної мережі.

3.Характер асортименту товарів.

4.Обсяги товарообігу торговельних підприємств.

5.Чисельність, стан і розташування об'єктів складського господарства.

6.Розвиток, розташування, спеціалізація, сезонність виробництва.

7.Наявність транспортних зв'язків між магазинами і джерелами постачання товарів.

8. Стан доріг, наявність і структура транспортних засобів.

9. Достовірність комерційної інформації, яка використовується для визначення потреби в товарах.

10.Рівень управління процесом товаропостачання.

11.Кваліфікація працівників торговельних підприємств, які визначають потребу в товарах.

3 переходом до ринкових відносин значно зросла чисельність роздрібних торговельних підприємств, в інтересах господарсько-торговельної діяльності яких фрактично організовується цей процес, і кожне з яких самостійно організовує його відповідно до власних уявлень, знань, вмінь та можливостей. Так, у 2017 році в Україні діяло 17504 роздрібних торговельних підприємства зі статусом юридичної особи, які спеціалізувалися на здійсненні торгівлі: товарами споживчого призначення (крім торгівлі транспортними засобами) 16372 од. (93,5 \%), з них продовольчими товарами - 9292 од. (53,1 \%), 
18 - Problèmes et perspectives d'introduction de la recherche scientifique innovante $\bullet$ Volume 2

непродовольчими товарами - 6829 од. (39,0 \%), транспортними засобами 1383 од. $(7,9 \%)$.

Принципова схема товаропостачання роздрібного торговельного підприємства (функціональна структура системи) включає такі основні етапи:

- визначення потреби в товарах;

- пошук джерел товаропостачання;

- вибір джерел товаропостачання і постачальників товарів;

- вибір форм товаропостачання;

- формування господарських зв'язків щодо закупівлі та постачання товарів, встановлення раціональних схем постачання;

- закупівля товарів через укладення угод на постачання товарів;

- забезпечення надходження товарів до торговельних підприємств, визначення раціональної частоти доставки i оптимальних розмірів партій завезення товарів, оперативний контроль за виконанням договорів поставки;

- організація доставки товарів в магазини;

- приймання товарів і його документальне оформлення (рис. 1)

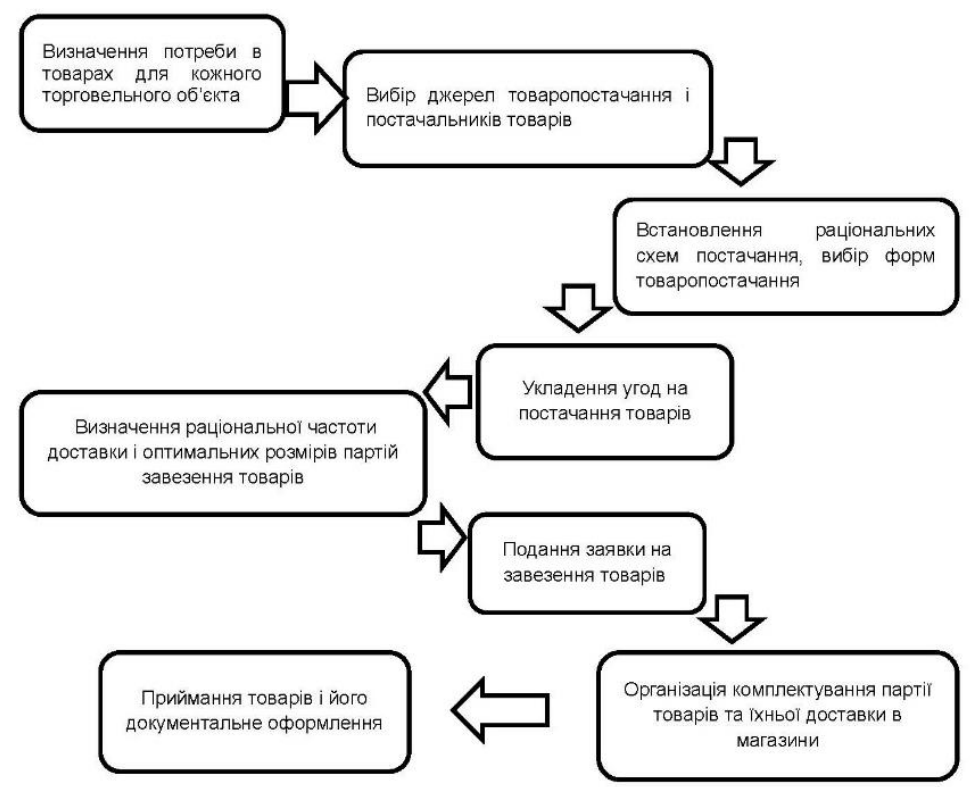

Рис. 1. Функціональна структура системи товаропостачання торговельних підприємств

Інтенсивний розвиток конкурентного середовища, що проявляється, насамперед, у формі відкриття великих супермаркетів та корпоративних торговельних мереж, негативно впливає на малі підприємства кооперативної торгівлі, діяльність яких пов'язана з великою витратоємністю і невисокою товарооборотністю; таке становище загострюється через недостатність та/або 
нераціональність використання власних оборотних коштів для забезпечення фрінансової стійкості торговельних підприємств споживчої кооперації. Водночас, через недостатньо ефеекивний менеджмент торговельні підприємства споживчої кооперації не змогли використати притаманні їм конкурентні переваги, пов'язані з наявністю власної розвинутої матеріальнотехнічної бази, можливостями економії витрат завдяки використанню кооперативного опту, багатогалузевим характером діяльності споживчої кооперації як джерела отримання власних товарних ресурсів, наявністю пайовиків як гарантованих покупців та ін.

Тому для побудови ефективної системи логістики підприємств кооперативної торгівлі в організаційних межах споживчої кооперації, перш за все, потрібно на єдиних засадах організовувати та керувати комерційними за своєю суттю процесами формування асортименту, закупівель і реалізації товарів, що означає необхідність повноцінної реалізації задекларованого раніше принципу створення централізованої служби закупівель товарів (з регіональними відділеннями, які б відповідно до прийнятої асортиментної моделі забезпечували формування асортименту кооперативних магазинів у частині товарів місцевих виробників).

Програма формування системи логістики в торгівлі споживчої кооперації повинна бути спрямована не лише на модернізацію матеріально-технічної бази, але й на ефективне інформаційне забезпечення управління роздрібним товарооборотом торговельних підприємств, що дозволить адекватно реагувати на зміни у зовнішньому середовищі їх функціонування, на будь-які підприємницькі заходи конкурентів, пристосовуватися до нестабільних умов ринкового середовища. Формування системи логістики торговельного підприємства споживчої кооперації має базуватися на широкому використанні торговельним підприємством (та його партнерами по інтегрованому логістичному ланцюгу) інформаційно-комп'ютерних технологій i сучасних програмних продуктів задля забезпечення ефрективного стратегічного, тактичного та оперативного управління процесами руху матеріальних (насамперед, товарних), а також інформаційних, фінансових та інших потоків в процесі товаропросування як в організаційних межах торговельного підприємства, так і поза ними.

Отже, враховуючи той фракт, що в умовах ринкової економіки, за наявності підприємств торгівлі різних форм власності, типів господарювання, різного рівня їхньої самостійності, істотно ускладнюється робота з формування потрібного товарного асортименту в підприємствах роздрібної торгівлі, вважаємо за доцільне рекомендувати використання ідей та інструментарію науки і практики управління логістикою в діяльності підприємств роздрібної торгівлі щодо формування системи їхнього товаропостачання та якісної системи управління процесами товаропостачання.

Операції, що виконуються у ході товаропостачання, мають певний кількісний вимір, що дає змогу широко застосовувати в управлінні і плануванні математичні методи з використанням засобів комп'ютерної техніки.

Для цього необхідно на основі принципів та методів формування логістичних інфрормаційних систем організувати чітку систему інформаційного зв'язку між виробниками, складами підприємств гуртової торгівлі, роздрібними 
торговельними підприємствами і транспортними підприємствами на підставі уніфікації форм документів та системи збирання інформації, яка б забезпечувала інфрормаційну підтримку логістичних за своєю суттю операцій 3 товарними потоками та організацію товаропостачання на основі єдиного інформаційного потоку і на базі сучасних методологій.

\title{
Список використаниз джерел:
}

1. Апопій, В. В. (2009). Організація торгівлі: Підручник. (3-е видання). Київ: Центр учбової літератури.

2. Відомості НКЦПФР. Вилучено 3 https:www.smida.gov.ua

3. Мазаракі, А. А. (2006). Торговельне підприємниитво: стратегія, політика, конкурентоспроможність. Київ: КНТЕУ.

4. Пономарьова, Ю. В. (2003). Логістика: навчальний посібник. Київ: Центр навчальної літератури.

\section{ЩО 3 ОПОДАТКУВАННЯМ РЕКЛАМ СПЛАЧЕНИХ У СОЦМЕРЕЖАХ?}

\author{
Омельчак Вікторія Дмитрівна \\ здобувач вищої освіти економічного фракультету \\ Запорізький національний університет \\ Науковий керівник: Саєнко Олена Романівна \\ канд. ек. наук, доцент кафедри обліку і оподаткування \\ Запорізький національний університет \\ УКРӒ̈̈А
}

У сучасному світі нерідко зустрічається, коли підприємства користуються рекламними послугами в соціальних мережах, що зареєстровані за межами України.

Юридична особа, що платить кошти за рекламні послуги за допомогою корпоративної платіжної картки через міжнародні платіжні системи, зобов'язані дотримуватись Положення про заходи захисту та визначення порядку здійснення окремих операцій в іноземній валюті (постанова Правління НБУ від 02.01.2019 р. № 5) та положень Інструкції, затвердженої постановою Правління НБУ від 12.11.2003 р. № 492.

Додержуючись ч.1 ст. 15 Закону України від 04.10.2014р. № 1702-VII «Про запобігання та протидію легалізації (відмиванню) доходів, одержаних злочинним шляхом, фрінансуванню тероризму та фрінансуванню розповсюдження зброї масового знищення», за допомогою корпоративної платіжної картки юридичним особам дозволено здійснювати розрахунки до 150 тис. грн. за один операційний день за зовнішньоекономічним договором.

Авансовий звіт подається довіреною особою за кошти витрачені з карти 3 додаванням роздрукованого підтверджуючого електронного документу. Виписка банку, що випустив цю платіжну картку, буде підтвердженням витрати грошових коштів при придбанні послуг юридичною 
особою на іноземних інтернет-сайтах, також підтвердженням $є$ відповідна квитанція від постачальника послуг.

Через те що на митній території України розташоване місце постачання послуг, платником ПДВ, відповідно до п. 180.2 ПКУ відповідальна особа за нарахування і сплату податку до бюджетуу разі постачання послуг нерезидентами, які не зареєстровані як платники податку, є отримувач послуг.

В такому випадку база нарахування ПДВ - договірна вартість послуг. На додачу, в національну валюту за курсом НБУ, який діяв на дату виникнення податкового зобов'язання, перераховується вартість послуг.

3 послуг нерезидента 3 місцем постачання на території України, зобов'язання з ПДВ нараховують згідно правил п. 187.8 ПКУ - на дату списання коштів з банківського рахунку платника в рахунок сплати послуг чи на дату оформлення документу, який підтверджує фракт постачання послуг нерезидентом.

В податковій накладній відображається сума нарахованих зобов'язань 3 ПДВ, що оформлена на операцію (п. 208.2 ПКУ). Ця податкова накладна, що зареєстрована у ЄРПН, є основою для відображення нарахованої суми ПДВ в складі податкового кредиту підприємства (п. 208.2, п.п «в» п. 198.1., п. 198.2 ПКУ).

Відповідно до п.п. 141.4.6 ПКУ сплачується податок за ставкою 20 відсотків суми виплат за власний рахунок, резидентами, що здійснюють виплати нерезидентам за виробництво і розповсюдження реклами.

\section{Список використаних джерел:}

1. Про затвердження Інструкції про порядок валютного нагляду банків за дотриманням резидентами граничних строків розрахунків за операціями з експорту та імпорту товарів (Постанова). Вилучено 3 http://sfs.gov.ua/zakonodavstvo/podatkovezakonodavstvo/normativno-pravovi-akti-z-pitan-kpr/postanovi-pravlinnya-nbu/73185.html

2. Про затвердження Положення про заходи захисту та визначення порядку здійснення окремих операцій в іноземній валюті (Положення). Вилучено 3 https://zakon.rada.gov.ua/laws/show/v0005500-19 


\title{
SECTION II. SCIENCES AGRICOLES
}

\section{EFFICIENCY OF USE OF LAND RESOURCES OF THE ENTERPRISE USING THE EXAMPLE OF THE FERGANA REGION}

\author{
Marupov Azizkhon Abbsoxonovich \\ Ph.D. applicant of the Department of Geodesy, Cartography and Cadasters \\ Fergana Polytechnic Institute \\ Scientific advicer: Yuldashev Gulyam \\ D.Sc. of agricultural science, deportment of «Soil Science» \\ Fergana State University \\ REPUBLIC OF UZBEKISTAN
}

Land resources are an essential prerequisite and natural basis for the creation of wealth. When land bonality scores are raised, and the role of land is truly enormous and diverse in the production of economic propensity. [1] It is a sine qua non for the existence of human society and its further habitation.

Land management is important in the agricultural economy and in the country as a whole. In industry, it functions as a foundation or spatial operating basis for placing production. In agriculture, production is related to the quality of the land, the nature and conditions of its use. Improving land fertility is an important production base without which agricultural production is unthinkable. [2]

The rational use of land ensures a steady increase in output from the same area, which is considered mixed crops. The nature of land use is due to many natural, historical, technical and economic factors.

The purpose of this work is to find methods of more efficient use of the land resources of the Fergana region. According to the objective, it is necessary to highlight several tasks:

1) To consider the essence, importance of land resources.

2) To consider the organizational and economic characteristics of the enterprise.

3) Identify ways to improve land use efficiency.

The agricultural land is an essential condition for the existence of human society, an indispensable means of meeting its diverse needs. Speaking about the use of land, in the past this implies its functioning in the sphere of public production and increase of fertility of the land according to the scales of points of bonality. $[1,2]$

Fertility means the property of the land to give the cultivated plants the necessary nutrients to produce a crop. Three types of fertility are distinguished: natural, artificial and economic. Natural (potential) fertility is seen as the result of a long soil-forming process. It is determined by nutrient reserves, their availability to plants, physical, mechanical and other properties of the soil layer formed on the original rocks in a certain climate.

Land monitoring and fertility play an important role in monitoring and monitoring in the land registry [3].

The state land registry cadaster is kept for ensuring rational use and protection of lands, by protection of the rights of owners, land users and tenants and creation of an objective basis for pricing of the earth, land tax, the rent. 
During the formation of the agricultural land inventory, the following operations are carried out:

- State registration of land use;

- Quantitative and qualitative land accounting;

- Land assessment, which includes soil rebalancing and economic valuation.

All the lands of the Republic of Uzbekistan are monitored regardless of the form of ownership, purpose and nature of use [4].

Monitoring identifies the following processes:

1) evolutionary (related to natural-historical development processes); Cyclical (daily subsistence allowance, seasonal, annual and other changes in nature);

2) anthropogenic situations (human results);

3) emergency situations (accidents, disasters, natural and environmental disasters, etc.).

Conclusions. The main tasks of land monitoring for efficient use of fertile soils of the region are:

1) timely detection of changes in the state of the land fund, their assessment, forecast and development of recommendations to prevent and eliminate the consequences of negative processes;

2) information support of the state land registry, control of land use and protection.

References:

1. Xakimova, K.R., Marupov, A.A. \& Mirzakarimova, G. M. (2019). Maintaining Cadastral Valuation for the Effective Use of Agricultural Lands of the Fergana Region. INTERNATIONAL JOURNAL OF ADVANCED RESEARCH IN SCIENCE, ENGINEERING AND TECHNOLOGY, 6-10

2. Marupov, A. A., Abdurahmanov, A. A., Ahmedov, B. B. (2019). Main Ways to Improve the Efficiency of Agricultural Land Use in the Fergana Valley Sample. INTERNATIONAL JOURNAL OF ADVANCED RESEARCH IN SCIENCE, ENGINEERING AND TECHNOLOGY, 6-10.

3. Land and cadastral works in different countries. Retrieved from http://kadastrovik.com

4. Shakirov, F. K. (2004). Organization of production at enterprises of agro-industrial complex under ed. Kolos, $62-69$.

\section{LE DEVELOPPEMENT DE LA TECHNOLOGIE DE L'UTILISATION DES DECHETS DE L'INDUSTRIE BRASSICOLE AVEC LA PRODUCTION DES SAUCISSES DIETETIQUES «HAMBIR»}

RESEARCH GROUP:

Ekaterina Gornitch

Enseignante au dépatement de la technologie de production et de transformation des produits agricoles Établissement de l'enseignement supérieur au budget de l'Etat fédéral "Yaroslavskaya Académie d'Etat d'agriculture»

Nadiègeda Soldatkina

Bachelor en 4 années Établissement de l'enseignement supérieur au budget de l'Etat fédéral "Yaroslavskaya Académie d'Etat d'agriculture» 
Problèmes et perspectives d'introduction de la recherche scientifique innovante $\bullet$ Volume 2

Evgeni Kudriachov

Bachelor en 4 années

Établissement de l'enseignement supérieur au budget de l'Etat fédéral "Yaroslavskaya Académie d'Etat d'agriculture»

Glenn Gbangho

Bachelor en 4 années

Établissement de l'enseignement supérieur au budget de l'Etat fédéral "Yaroslavskaya Académie d'Etat d'agriculture»

FÉDÉRATION DE RUSSIE

Introduction. De nos jours les industries brassicoles se developpent avec un rythme rapide, en particulier les brasseries artisanales, puisque leur demande est constante et augmente. Malgré cela les producteurs fonts face aux problèmes d'utilisations des déchets obtenus. Au moment actuel, les grandes brasseries dessechent independamment les graines d'orges écrasées pour la fabrcation de bières et les lévures qui seront ensuite utilisées pour l'alimentation du bétail, ou soit elles le font avec l'aide des firmes spécialisées dans le dessèchement de ces résidus.

A notre avis, cela est quelques peu inapproprié car par exemple les graines écrasées d'orges et les restes de protéines après la filtration de la menthe de bière ont une importante valeur nutritionnelle.

La nouveauté scientifique est qu'en ce moment il n'y a pas un produit indetique au jambon «Hambir». II n'y a pas d'infomations sur l'idée des consommateurs et des documents normatifs. Dans la composition du produit, l'on n'utilise pas la combinaison standarte de la viande comme matière première, mais l'on utilise plus concrètement les viandes de dinde et de bœuf. A l'heure actuelle, les dechets de la production de bière sont rarement utilisés dans la production des produits alimentaires. Déchet à l'aide duquel l'on peut réguler les indicateurs organoleptiques sous condition de reduction de la proportion de sel dans la recette.

Résultats. Beaucoup de gens sont d'accord, que le rythme déchainé par lequel vie moderne décolle, laisse des traces non seulement sur la ration de l'homme mais aussi sur sa santé. Le choix des produits alimentaires de mauvaises qualités avec une taux élévé de graisses, sels, produits chimiques néfastes à la santé, faible taux de protéines et de celulloses peut apporter des maladies telles que : l'hypertension, maladie gastro-intestinales, thrombose, l'accident cardio-vasculaire, crise cardique, anemie, oncologie etc ... c'est pourquoi le devellopement de la technologie de production du jambon naturel «Hambir» obtenu de la viande diététique de dinde, veaux et l'enrichissement de la cellulose est d'actualité pour le grand cercle des consommateurs : les enfants, les sportifs, les studiants, les patients des institutions médecinales. Selon TR TU 034/2013 reglèment technique union douanière " sécurité de viande et le produit à base de viande » saussisses - est un produit à base de viande, préparé à partir d'un mélange de viande hachée et des ingrédients tels que les épices et condiments écrasés, déposé dans un boyau à saussise, un paquet en forme de tube et refermé aux extrémités, exposé à un traitement thermique ou non soumis à un traitement thermique jusqu'à sa préparation. 
Comme matière première, ont été choisis la viande de dinde et celle de veau, car ces viandes sont non seulement riches en protéines mais aegalement en vitamines $B$, E, le potassium, le phosphore, acide folique, le zinc, le fer et d'autres micro-élements sauf ceux qui contiennent moins de graisse contrairement à la viande de port.

La graine écrasée d'orge est un produit précieux du point de vue de la biologique, pour $100 \mathrm{grammes}$, il existe respectivement $23 \mathrm{~g}$ de protéines, $14 \mathrm{~g}$ de celluloses, 0,205 mg de fer, 0,11 mg de zinc, outre cela, une grand nombre d'acides aminés (lysine, glycine, alanine, tréonine etc...). Dans le but de conserver les substances utiles, il a été developpé un schéma technique de la préparation du jambon «Hambir» avec l'addition des grains crus qui se résume au dessin 1 suivant:

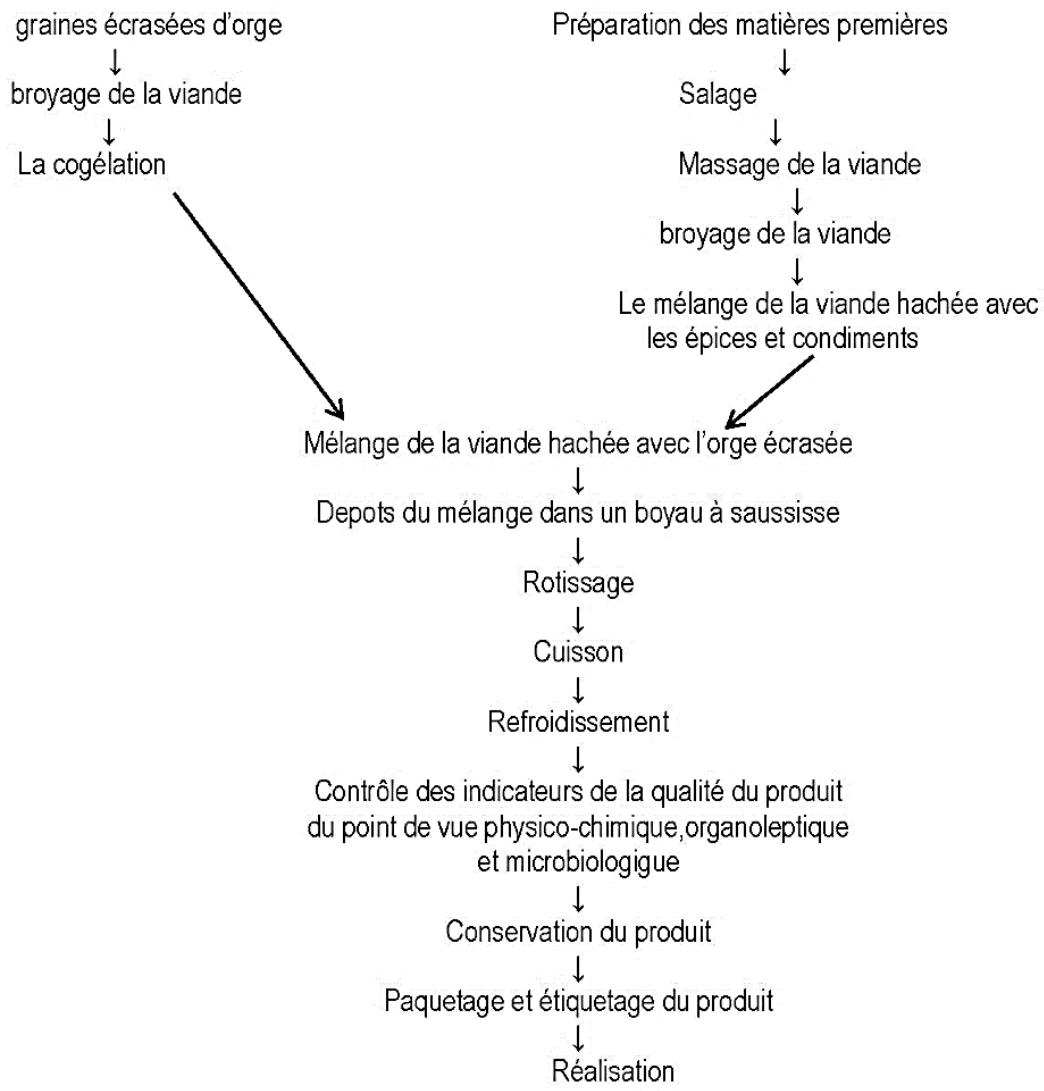

Dessin 1. Schéma technique de la réalisation du jambom «Hambir»

La description du schéma technique est présentée dans le tableau ci-dessous. 
Description des opérations techniques de production

Tableau 1

\begin{tabular}{|c|c|c|c|}
\hline Titre des opérations & Signification & Régime & Equipements \\
\hline $\begin{array}{l}1 \text { Préparation des } \\
\text { matières premières }\end{array}$ & $\begin{array}{l}\text { Enlever l'emballage, décapage de la } \\
\text { viande si nécéssaire, décongélation } \\
\text { des graines d'orges écrasées et défini } \\
\text { la quantité de matière première }\end{array}$ & $10 \pm 2^{\circ} \mathrm{C}$ & Table \\
\hline 1.1 Pressage d'orges & $\begin{array}{l}\text { Suppression à excès d'eau ou } \\
\text { d'humidité }\end{array}$ & Humidité $75 \%$ & $\begin{array}{l}\text { Machine à pressage } \\
\text { d'orge }\end{array}$ \\
\hline $\begin{array}{l}1.2 \text { Broyage des } \\
\text { graines d'orges }\end{array}$ & $\begin{array}{l}\text { Création d'une consistance visqueuse } \\
\text { et uniforme }\end{array}$ & $\begin{array}{c}\text { Niveau de } \\
\text { broyage } 1 \ldots 2 \mathrm{~mm}\end{array}$ & Moulin à orge \\
\hline $\begin{array}{l}1.3 \text { Cogélation des } \\
\text { graines broyées }\end{array}$ & \begin{tabular}{|l|} 
Augmentation de la durée de \\
vie,création de stock de matière \\
premère, assurer le travail continu de \\
l'équipement
\end{tabular} & $\begin{array}{l}\text { Température } \\
18 \pm 2^{\circ} \mathrm{C}\end{array}$ & Congelateur \\
\hline 2 Salage & $\begin{array}{l}\text { Rendre la viande salée, viscosité, } \\
\text { résistance des micro-organismes, } \\
\text { augmenter sa capacité de rention en } \\
\text { eau pendant le traitement thermique. }\end{array}$ & $\begin{array}{l}\text { Possibilité sèche } \\
2 \pm 2^{\circ} \mathrm{C} \text {, en } \\
\text { morceau } 24 \\
\text { heures }\end{array}$ & Masseur à viande \\
\hline $\begin{array}{l}3 \text { Massage de la } \\
\text { viande }\end{array}$ & Accélération du processus de salage & $\begin{array}{l}\text { 2...3 heures, } \\
8 \pm 2^{\circ} \mathrm{C}\end{array}$ & Masseur à viande \\
\hline 4 Broyage & $\begin{array}{l}\text { Destruction de la stucture des } \\
\text { celluloses de la viande et optention } \\
\text { d'une masse uniforme et visqueuse. }\end{array}$ & $\begin{array}{l}\text { Niveau de } \\
\text { broyage } 8 \ldots 12 \\
\text { mm, }\end{array}$ & Hachoir \\
\hline $\begin{array}{l}5 \text { Mélange de la } \\
\text { viande hachée avec } \\
\text { les épices et les } \\
\text { condiments }\end{array}$ & $\begin{array}{l}\text { Introduction des ingrédients } \\
\text { aromatiques }\end{array}$ & $5 . .8$ minutes & Malaxeur \\
\hline $\begin{array}{l}6 \text { Mélange de la } \\
\text { viande hachée avec } \\
\text { les graines d'orges } \\
\text { écrasées }\end{array}$ & $\begin{array}{l}\text { Melange de la viande hacchée et les } \\
\text { légumes en conformité avec la recette }\end{array}$ & $5 \ldots 8$ minutes & Malaxeur \\
\hline $\begin{array}{l}7 \text { Le dépôt de la } \\
\text { viande hachée dans } \\
\text { le boyau à saussisse }\end{array}$ & Definir une forme & $\begin{array}{c}\text { Pression } 0,4 \ldots 0,5 \\
\mathrm{mPa}\end{array}$ & $\begin{array}{l}\text { Poussoir pneumatique } \\
\text { à saussisse }\end{array}$ \\
\hline 8 Reste & $\begin{array}{l}\text { La viande hachée compactée en une } \\
\text { espèce, le produit fini obtenu est plus } \\
\text { juteux, avec une meilleure consistance }\end{array}$ & $2 . . .4$ heures & Cadres à saussisse \\
\hline 8 Rotissage & $\begin{array}{l}\text { Donner une structure d'espèce de } \\
\text { saussisse }\end{array}$ & $85 \pm 10^{\circ} \mathrm{C}$ & Four \\
\hline 9 Cuisson & $\begin{array}{l}\text { Fournir la perte à } 99 \% \text { de microflores } \\
\text { végétatives; disponibilité culinaire du } \\
\text { produit est autorisée. }\end{array}$ & $\begin{array}{l}\text { De } 75 \pm 85^{\circ} \mathrm{C}, \\
35 \ldots 45 \text { minutes, à } \\
\text { une temperature } \\
\text { interne } 70 \pm 1^{\circ} \mathrm{C}\end{array}$ & Chaudrière de cuisson \\
\hline 10 Refroidissement & $\begin{array}{l}\text { Dans le but de diminuer les perte due } \\
\text { une évaporation intensive }\end{array}$ & $\begin{array}{c}\text { A une } \\
\text { température } \\
\text { interne } 4 \pm 4^{\circ} \mathrm{C}\end{array}$ & Chambre froide \\
\hline $\begin{array}{l}11 \text { paquetage et } \\
\text { étiquetage }\end{array}$ & Présentation de l'echantillon du produi & $\begin{array}{c}\text { Température } \\
\text { avant le } \\
\text { paquetage ne doit } \\
\text { pas dépassé } \\
15^{\circ} \mathrm{C} .\end{array}$ & $\begin{array}{l}\text { Table pour paquetage } \\
\text { et étiquetage }\end{array}$ \\
\hline 12 Conservation & $\begin{array}{l}\text { Dans le but de l'optimisaton des frais } \\
\text { de transport. }\end{array}$ & $4 \pm 2^{\circ} \mathrm{C}$ & Salle de conservation \\
\hline 13 Réalisation & Mise au marcher du produit fini. & $4 \pm 2^{\circ} \mathrm{C}$ & - \\
\hline
\end{tabular}

Conclusion. Les propriétés utiles et principales de la matière première du jambon « Hambir » seront bénéfiques et le différencient des analogies présentées 
au marché dont les importantes composantes sont les viandes de bœuf et porc, aussi les producteurs utilisent le volail (poulet). Grace à l'addition de la malte de bière les saussisse seront enrichi de celluloses qui contribue à reduire la glycémie et améliore le travail du système digestif, facilite la perte de poids, élimine le risque d'attraper le diabète et les maladies oncologiques.

\section{Références:}

1. TR TU 034/2013 Le règlement technique de l'union douanère «Sur la sécurité de la viande et les produits à base de viande».

2. Zubariova, T. G., Тимакова Т. С, Сенченко М.А. (2018). Technologie de consevation et de transformation de produits animaux. Practicum pour les bachelors en 35.03.07 «Technologie de production et de transformation des produits agricoles ou agro-insdutriels». Yaroslav: Établissement de l'enseignement supérieur au budget de l'Etat fédéral Academie d'Etat de Yaroslav.

DOI 10.36074/29.11.2019.v2.15

\section{АКТИВНІСТЬ ФЕРМЕНТУ КАТАЛАЗА ЧОРНОЗЕМІВ ТИПОВИХ ЗА РІЗНИХ СИСТЕМ ЗЕМЛЕРОБСТВА}

ORCID ID: 0000-0002-2703-1021

Рєзнік Сергій Вадимович

аспірант кафедри ґрунтознавства Харківський національний аграрний університет ім. В. В. Докучаєва ORCID ID: 0000-0001-6516-7846

Гавва Дмитро Вікторович канд. с.-г. наук, доцент кафедри ґрунтознавства Харківський національний аграрний університет ім. В. В. Докучаєва УКРАЇHA

Під час дослідження біологічної активності агрогенних ґрунтів зосереджують увагу на вивченні впливу чинників на активність мікробоценозів $[1,2]$. Але поза увагою вчених залишається питання впливу гідротермічних чинників на стан активності мікробіоценозів ґрунту.

У науковій літературі відсутні дані стосовно впливу коливань температури та вологості на фрерментативну активність у ґрунтах. Оскільки температурні показники і вологість здатні вплинути на швидкість синтезу ферментів у ґрунтах через доступність субстрату та активізації мікробіологічної діяльності $[3,4]$.

Науковцями доведено підвищення активності фрерментів ґрунтів за умов зростання температури [5]. Інші дослідники встановили зниження активності ґрунтових фрерментів порівняно з холодним ґрунтом. Під час підвищення температур було зафіксовано зниження активності гідролаз, а активність оксидоредуктаз не змінюється [6, 7]. Активність фрерментів ґрунтів залежить від коливань вологості, зокрема активність гідролітичних ферментів підвищувалась з опадами, а після втрат доступної вологи у ґрунтах зменшувалась [8].

Активність фрерментів у ґрунтах розглядають як процеси, що активуються позаклітинними і внутрішньоклітинними ферментами ґрунтової біоти. 
Надходячи до ґрунту і стабілізуючись у ньому, ферменти стають не від'ємною частиною ґрунту та створюють унікальну ферментативну активність, що властива конкретним типам ґрунтів. [9, 10].

Найбільш поширеною у ґрунтах із окисно-відновних фрерментів є каталаза, яка утворюється у процесі життєдіяльності мікроорганізмів, водоростей та кореневої системи рослин. Каталаза розкладає перекис водню утворений у процесі дихання та в результаті біохімічних реакцій окислення органічних речовин (основна ланка синтезу гумусових речовин у ґрунті). Активність ферменту каталаза це сталий й інфрормативний показник для діагностики ґрунтів. Активність каталази використовують під час дослідження типів ґрунтів, характеристики біологічних властивостей та оцінці навантаження агрогенних чинників [11]. Кольцова О.М. встановила зв'язок активності ферменту та кислотності ґрунту, та підкреслила підвищення каталазної активності за умов зростання вмісту органічної речовини [12].

Активність ферменту каталаза досліджували протягом 2018 р. у чорноземах типових глибоких середньосуглинкових на лесах Лівобережжя Лісостепу України у межах Зіньківського р-ну Полтавської обл., які перебувають у різному використанні: озима пшениця (органічна система землеробства), переліг (понад 20 років без обробітку), кукурудза на зерно (органічна система землеробства) та кукурудза на зерно (інтенсивна система землеробства). Активність ферменту каталаза визначена газометричним методом за А. Ш. Галстяном [11] у 0-10, 10-20, 20-30, 30-40-сантиметрових шарах ґрунтів. Забезпеченість ґрунтів ферментом каталаза оцінювали згідно Звягінцева [10].

Аналізуючи отримані дані (рис. 1) відзначимо тренд підвищення активності ферменту каталаза з весни $\left(2,5-7,4 \mathrm{~cm}^{3} \mathrm{O}_{2}\right.$ на 1 г грунту за 1 хв.) до осені $(3,4-$ $8,1 \mathrm{~cm}^{3} \mathrm{O}_{2}$ на 1 г ґрунту за 1 хв.). Зафріксовано підвищення фрерментативної активності у ґрунтах, що задіяні в органічній системі землеробства. Найбільшу активність ферменту каталаза $\left(5,8-8,1 \mathrm{~cm}^{3} \mathrm{O}_{2}\right.$ на 1 г ґрунту за 1 хв.) зафіксовано у варіанті озимої пшениці, що висіяна після заробки у ґрунт вики ярої (сидерат). Та значне зниження активності каталази у варіанті кукурудзи на зерно $\left(2,5-4,5 \mathrm{~cm}^{3} \mathrm{O}_{2}\right.$ на 1 г ґрунту за 1 хв.), що вирощується за інтенсивної системи землеробства.

Таблиця 1

Активність ферменту каталаза та гідротермічні показники чорноземів типових агрогенного використання

\begin{tabular}{|c|c|c|c|c|c|c|c|c|c|c|}
\hline \multirow[t]{2}{*}{ Варіанти } & \multirow{2}{*}{$\begin{array}{r}\text { Глиби- } \\
\text { на, см }\end{array}$} & \multicolumn{3}{|c|}{$\begin{array}{c}\text { Каталаза, см }{ }^{3} \mathrm{O}_{2} \text { на } 1 \\
\text { г ґрунту за } 1 \text { хв. }\end{array}$} & \multicolumn{3}{|c|}{ Вологість, \% } & \multicolumn{3}{|c|}{ Температкра, ${ }^{\circ} \mathrm{C}$} \\
\hline & & весна & літо & осінь & весна & Літо & осінь & весна & літо & осінь \\
\hline \multirow{4}{*}{$\begin{array}{c}\text { Озима } \\
\text { пшениця } \\
\text { (органічна } \\
\text { система } \\
\text { земле-- } \\
\text { робства) }\end{array}$} & $0-10$ & 7,4 & 6,9 & 7,9 & 20,1 & 19,5 & 19,5 & 20,0 & 25,9 & 4,5 \\
\hline & $10-20$ & 7,0 & 6,8 & 7,5 & 22,6 & 21,8 & 18,7 & 18,0 & 26,0 & 2,2 \\
\hline & $20-30$ & 6,8 & 7,4 & 8,1 & 24,1 & 19,6 & 18,4 & 17,5 & 25,7 & 0,2 \\
\hline & $30-40$ & 5,8 & 6,2 & 6,9 & 25,1 & 14,6 & 18,9 & 16,8 & 24,0 & 0,6 \\
\hline \multirow{4}{*}{ Переліг } & $0-10$ & 5,6 & 5,8 & 7,9 & 23,2 & 13,8 & 26,1 & 18,0 & 22,5 & 3,7 \\
\hline & $10-20$ & 5,0 & 5,3 & 5,4 & 25,0 & 15,5 & 16,4 & 17,4 & 21,2 & 1,6 \\
\hline & $20-30$ & 5,3 & 5,9 & 5,6 & 26,2 & 15,7 & 16,4 & 16,5 & 20,7 & 0,4 \\
\hline & $30-40$ & 4,8 & 5,1 & 4,7 & 26,3 & 17,7 & 15,8 & 15,6 & 20,2 & 1,1 \\
\hline \multirow{2}{*}{$\begin{array}{l}\text { Кукурудза } \\
\text { на зерно }\end{array}$} & $0-10$ & 5,5 & 6,7 & 6,8 & 26,3 & 20,2 & 24,7 & 14,8 & 21,6 & 3,4 \\
\hline & $10-20$ & 5,2 & 6,4 & 6,3 & 24,5 & 19,9 & 25,7 & 15,2 & 21,5 & 2,1 \\
\hline
\end{tabular}


Продовження табл. 1

\begin{tabular}{|c|c|c|c|c|c|c|c|c|c|c|}
\hline \multirow[t]{2}{*}{ Варіанти } & \multirow{2}{*}{$\begin{array}{l}\text { Глиби- } \\
\text { на, см }\end{array}$} & \multicolumn{3}{|c|}{\begin{tabular}{|c|}
$\mid$ Каталаза, см $^{3} \mathrm{O}_{2}$ на 1 \\
г ґрунту за 1 хв.
\end{tabular}} & \multicolumn{3}{|c|}{ Вологість, \% } & \multicolumn{3}{|c|}{ Температкра, ${ }^{\circ} \mathrm{C}$} \\
\hline & & Весна & літо & осінь & весна & Літо & осінь & весна & літо & осінь \\
\hline \multirow{2}{*}{$\begin{array}{c}\text { (органічна } \\
\text { система } \\
\text { земле- } \\
\text { робства) }\end{array}$} & $20-30$ & 6,0 & 6,6 & 7,1 & 28,6 & 19,0 & 17,5 & 15,7 & 21,4 & 0,3 \\
\hline & $30-40$ & 5,6 & 5,5 & 6,7 & 27,7 & 17,8 & 16,7 & 15,2 & 21,3 & 0,8 \\
\hline \multirow{4}{*}{$\begin{array}{c}\text { Кукурудза } \\
\text { на зерно } \\
\text { (інтенсивна } \\
\text { система } \\
\text { земле-- } \\
\text { робства) }\end{array}$} & $0-10$ & 2,5 & 3,7 & 3,8 & 17,6 & 12,8 & 16,5 & 15,3 & 23,0 & 3,7 \\
\hline & $10-20$ & 2,5 & 3,5 & 3,8 & 22,2 & 14,6 & 24,6 & 15,5 & 22,5 & 2,9 \\
\hline & $20-30$ & 2,8 & 4,4 & 4,0 & 25,8 & 16,2 & 22,0 & 16,1 & 20,8 & 1,1 \\
\hline & $30-40$ & 2,6 & 4,5 & 3,4 & 26,5 & 16,0 & 17,6 & 15,5 & 20,3 & 1,9 \\
\hline \multicolumn{2}{|c|}{ HCP05 } & 0,32 & 0,26 & 0,29 & & & & & & \\
\hline
\end{tabular}

Варто зазначити, що в усіх досліджуваних варіантах зафріксовано зниження ферментативної активності у шарах $10-20 \mathrm{~cm}$ до значень $2,5-7,5 \mathrm{~cm}^{3} \mathrm{O}_{2}$ на 1 г ґрунту за 1 хв. Також відмітимо максимальні значення активності каталази у варіанті перелогу у шарі 0-10 см і коливалися в межах 5,6-7,9 $\mathrm{cm}^{3} \mathrm{O}_{2}$ на 1 г ґрунту за 1 хв, тоді як в агрогенних ґрунтах не залежно від систем землеробства найбільшу активність каталази зафріксовано у шарі 20-30 см 2,8$8,1 \mathrm{~cm}^{3} \mathrm{O}_{2}$ на 1 г ґрунту за 1 хв.

Згідно оціночної шкали (табл. 2) усі досліджувані ґрунти мають середню забезпеченість фрерментом каталаза (3-10 см 2,8-8,1 cм ${ }^{3} \mathrm{O}_{2}$ на 1 г ґрунту за 1 хв). Винятком $€$ варіант кукурудзи на зерно, що вирощувалася за інтенсивної системи землеробства, де було зафіксовано зниження активності ферменту каталази навесні до значень 2,5-2,8 см $^{3} \mathrm{O}_{2}$ на 1 г ґрунту за 1 хв., що відповідає бідному забезпеченню (1-3 $\mathrm{cm}^{3} \mathrm{O}_{2}$ на 1 г ґрунту за 1 хв.).

Таблиця 2

Шкала забезпеченості ґрунтів ферментом каталаза (за Звягінцевим, 1978)

\begin{tabular}{|c|c|}
\hline Забезпеченість ґрунтів & $\mathrm{cm}^{3} \mathrm{O}_{2}$ на 1 г ґрунту за 1 хв. \\
\hline Дуже бідні & $<1$ \\
\hline Бідні & $1-3$ \\
\hline Середня забезпеченість & $3-10$ \\
\hline Багаті & $10-30$ \\
\hline Дуже багаті & $>30$ \\
\hline
\end{tabular}

Згідно кореляційного аналізу виявлено дуже тісний взаємозв'язок показників активності ферменту каталази за порами року (весна-літо-осінь) на рівні 0,90-0,94. Також виявлено позитивний вплив вологості ґрунтів на показники активності досліджуваного ферменту влітку $(0,74)$ та температурних показників навесні $(0,60)$ та влітку $(0,49)$.

Висновки. 1.Усі досліджувані ґрунти мають середню забезпеченість ферментом каталаза. 2. Органічне виробництво, яке передбачає використання органічних добрив, призводить до підвищення активності ферменту каталаза до рівня 5,2-8,1 $\mathrm{cm}^{3} \mathrm{O}_{2}$ на 1 г ґрунту за 1 хв., тоді як за інтенсивної системи землеробства зафіксовано значне зменшення активності каталази до значень 2,5-4,5 $\mathrm{cm}^{3} \mathrm{O}_{2}$ на 1 г ґрунту за 1 хв. 3. Переліжне 
$30 \bullet$ Problèmes et perspectives d'introduction de la recherche scientifique innovante $\bullet$ Volume 2

використання чорноземів типових обумовило середні значення активності фрерменту каталаза 4,7-7,9 $\mathrm{cm}^{3} \mathrm{O}_{2}$ на 1 г ґрунту за 1 хв. 4. Активність досліджуваного фрерменту залежить від температури ґрунту, тоді як вологість ґрунтів мала найбільший вплив влітку, коли спостерігалась нестача атмоссрерних опадів.

\section{Список використаних джерел:}

1. Малиновська, І.М., Гаврилов, С.О. (2014). Вплив способу обробітку на спрямованість та напруженість мікробіологічних процесів у сірому лісовому ґрунті. Ґрунтознавство, (15), 5362.

2. Москалевська, Ю.П., Патика, М.В. \& Танчик, С.П. (2015). Особливості формування мікробного комплексу чорнозему типового в агроценозі буряка цукрового. Наук. доп. НУБіП України, (50). Вилучено із http://nbuv.gov.ua/j-pdf/Nd_2015_1_7.pdf

3. Fogarty, W.M., Kelly, C.T. (2012). Microbial enzymes and biotechnology. Springer: Science and Business Media.

4. Shukla, G., Varma, A. (2011). Soil Enzymology. Springer.

5. Bell, T.H., Henry, H.A.L. (2011). Fine scale variability in soil extracellular enzyme activity is insensitive to rain events and temperature in a mesic system. Pedobiologia, 54, 141-146.

6. Weedon, J.T., Kowalchuk, G.A., Aerts, R. [et al.]. (2011). Summer warming accelerates sub-arctic peatland nitrogen cycling without changing enzyme pools or microbial community structure. Global Change Biology, 10, 1365-2486.

7. Kardol, P.E., Cregger, M.A., Campany, C.E. [et al.]. (2010). Soil ecosystem functioning under climate change: plant species and community effects. Ecology, 91, 767-781.

8. Ladwig, L.M., Sinsabaugh, R.L., Collins, S.L. (2015). Soil enzyme responses to varying rainfall regimes in Chihuahuan Desert soils. Ecosphere, 6(3), 123-130.

9. Волкогон, В.В. (ред.), Надкернична, О.В., Токмакова, Л.М. [та ін.]. (2010). Експериментальна грунтова мікробіологія: монографія. Київ: Аграрна наука.

10. Звягинцев, Д.Г. (1978). Биологическая активность почв и шкалы для оценки некоторых еe показателей. Почвоведение, 6, 48-54.

11. Хазиев, Ф.Х. (2005). Методы почвенной энзимологии. Москва: Наука.

12. Кольцова, О.М. (2012). Биологическая диагностика состояния чернозема выщелоченого типичной лесостепи. Вестник Воронежского государственного аграрного университетата, 1, 7-11. 


\section{ПОЖИВНІСТЬ ЗЕЛЕНОÏ МАСИ РІЗНИХ СОРТІВ КОНЮШИНИ}

Вихопень Юліан Богданович

магістрант фракультету агротехнологій і екології

Львівський національний аграрний університет

Павкович Сергій Ярославович

канд. с.-г. наук, доцент, доцент кафедри тваринництва і кормовиробництва

Львівський національний аграрний університет

УKPAÏHA

Одним 3 головних завдань агропромислового комплексу України $€$ забезпечення тваринництва високоякісними кормами, що можливе за рахунок розширення площ посіву багаторічних бобових трав, у тому числі конюшини лучної. Зелена маса конюшини має високу перетравність, високий вміст протеїну, мінеральних речовин та вітамінів. Вона добре поїдається худобою і швидко відростає після випасання та скошування. Конюшина лучна поліпшує поживний, повітряний та водний режими ґрунту, відновлює його структуру та стимулює нагромадження гумусу [1].

Проте сучасне кормовиробництво вимагає таких сортів конюшини лучної, які поєднували б високий біологічний потенціал урожайності, з високою поживністю, високою адаптивною здатністю та стійкістю до хвороб і шкідників [2]. Тому дослідження, які стосуються вивчення поживної цінності зеленої маси конюшини лучної різних сортів $€$ актуальними.

У дослідженнях використовували конюшину лучну сортів Передкарпатська 6 і Трускавчанка, яку вирощували на дерново-підзолистих ґрунтах.

Середні проби зеленої маси конюшини для зоотехнічного аналізу відбирали відразу після скошування. Поживність зеленої маси визначали у вівсяних кормових одиницях.

В результаті наших досліджень встановлено, що поживність 1 кг зеленої маси конюшини сорту Передкарпатська 6 становила 0,18 кормових одиниць, а сорту Трускавчанка - 0,19 кормових одиниць (табл.).

Таблиця 1

Поживність зеленої маси конюшини лучної різних сортів

\begin{tabular}{|c|c|c|c|c|c|}
\hline Показник & Copt & Протеїн & Жир & Клітковина & БEP \\
\hline \multirow{2}{*}{ Вміст поживних речовин, \% } & Передкарпатська 6 & 3,92 & 0,62 & 4,64 & 8,95 \\
\hline & Трускавчанка & 4,14 & 0,74 & 4,31 & 9,22 \\
\hline \multirow{2}{*}{$\begin{array}{l}\text { Вміст поживних речовин в } 1 \text { кг } \\
\text { корму, г }\end{array}$} & Передкарпатська 6 & 39,2 & 6,2 & 46,4 & 89,5 \\
\hline & Трускавчанка & 41,4 & 7,4 & 43,1 & 92,2 \\
\hline \multirow{2}{*}{ Коефіцієнт перетравності, \% } & Передкарпатська 6 & \multirow{2}{*}{70} & \multirow{2}{*}{61} & \multirow{2}{*}{51} & \multirow{2}{*}{76} \\
\hline & Трускавчанка & & & & \\
\hline \multirow{2}{*}{$\begin{array}{l}\text { Вміст перетравних поживних } \\
\text { речовин в } 1 \text { кг корму, г }\end{array}$} & Передкарпатська 6 & 27,4 & 3,8 & 23,7 & 68,0 \\
\hline & Трускавчанка & 29,0 & 4,5 & 22,0 & 70,0 \\
\hline \multirow[t]{2}{*}{ Константи жировідкладення } & Передкарпатська 6 & \multirow[t]{2}{*}{0,235} & 0,474 & \multirow[t]{2}{*}{0,248} & 0,248 \\
\hline & $\begin{array}{l}\text { Трускавчанка } \\
\text { Передкарпатська } 6\end{array}$ & & 1.8 & & 167 \\
\hline Очікуване жировідкладення, г & Трускавчанка & 6,8 & 2,1 & 5,5 & 17,4 \\
\hline \multirow{2}{*}{$\begin{array}{l}\text { Очікуване відкладення жиру } 3 \\
1 \text { кг корму, г }\end{array}$} & Передкарпатська 6 & \multicolumn{4}{|c|}{30,8} \\
\hline & Трускавчанка & \multicolumn{4}{|c|}{31,8} \\
\hline
\end{tabular}


Problèmes et perspectives d'introduction de la recherche scientifique innovante • Volume 2

Продовження табл. 1

\begin{tabular}{|c|c|c|c|c|c|}
\hline Показник & Сорт & Протеїн & Жир & Клітковина & БEP \\
\hline \multirow{2}{*}{ Знижувальна дія клітковини } & Передкарпатська 6 & \multicolumn{4}{|c|}{3,8} \\
\hline & Трускавчанка & \multicolumn{4}{|c|}{3,5} \\
\hline \multirow{2}{*}{$\begin{array}{l}\text { Фактичне відкладення жиру } 3 \\
1 \text { кг корму, г }\end{array}$} & Передкарпатська 6 & \multicolumn{4}{|c|}{27,0} \\
\hline & Трускавчанка & \multicolumn{4}{|c|}{28,3} \\
\hline \multirow{2}{*}{$\begin{array}{l}\text { Вміст в } 1 \text { кг корму кормових } \\
\text { одиницц, кг }\end{array}$} & Передкарпатська 6 & \multicolumn{4}{|c|}{0,18} \\
\hline & Трускавчанка & \multicolumn{4}{|c|}{0,19} \\
\hline
\end{tabular}

Висновки. Для забезпечення тваринництва більш поживним кормом, пропонуємо на вказаних ґрунтах вирощувати сорт конюшини Трускавчанка.

\section{Список використаних джерел:}

1. Демидась, Г.І. \& Галушко, І.В. (2018). Кормова продуктивність конюшини лучної залежно від технології вирощування в Правобережному Лісостепу. Рослинництво та грунтознавство, (286), 11-17.

2. Х Харченко, Ю.В., Кочерга, В.Я. \& Холод С.М. (2013). Продуктивність зразків конюшини лучної (Trifolium pratense L.) в умовах Устимівської дослідної станції рослинництва. Корми i кормовиробниитво, (76), 54-58.

\section{ПРОДОЛЖИТЕЛЬНОСТЬ СЕРВИС-ПЕРИОДА И ИНДИФФЕРЕНС-ПЕРИОДА У КОРОВ РАЗНЫХ ГЕНОТИПОВ В УСЛОВИЯХ МОСКОВСКОЙ ОБЛАСТИ}

Мухтарова Ольга Михайловна, кандидат сельскохозяйственных наук, ассистент кафедры генетики и разведения животных имени В.Ф. Красоты Федеральное государственное бюджетное образовательное учреждение высшего образования «Московская Государственная Академия Ветеринарной Медицины и Биотехнологии - МВА имени К.И. Скрябина»

Бакай Анатолий Владимирович, доктор сельскохозяйственных наук, профессор кафедры генетики и разведения животных имени В.Ф. Красоты Федеральное государственное бюджетное образовательное учреждение высшего образования «Московская Государственная Академия Ветеринарной Медицины и Биотехнологии - МВА имени К.И. Скрябина» РОССИЙСКАЯ ФЕДЕРАЦИЯ

В практической селекции оценка воспроизводительных качеств животных является основной, поскольку главная задача зоотехнических служб направлена на получение за один учетный год - одного здорового теленка от одной коровы [4]. Голштинизированные коровы, при наличии в генотипе высокой продуктивности, повсеместно отличаются нестандартными показателями сервис-периода и межотельного периода [3]. Мы изучили продолжительность сервис-периода (периода от отела до плодотворного 
осеменения) и индиффреренс-периода (периода от отела до первого осеменения) у дочерей таких быков-лидеров голштинской породы немецкой селекции, использующихся в условиях Московской области, как Звездный 1429, Лав 7899, Неритон 398411 и Сатурн 35201 (табл. 1).

Таблица 1

Воспроизводительные качества коров разных генотипов

\begin{tabular}{|c|c|c|c|c|c|}
\hline Хозяйство & $\mid \begin{array}{c}\text { Племенной } \\
\text { бык }\end{array}$ & $\begin{array}{c}\text { Число } \\
\text { дочерей }\end{array}$ & Показатели & Сервис-период, дн. & $\begin{array}{c}\text { Индифференс- } \\
\text { период, дн. }\end{array}$ \\
\hline \multirow{4}{*}{$\begin{array}{l}\text { ОАО } \\
\text { «Вохри- } \\
\text { нка» }\end{array}$} & $\begin{array}{c}\text { 3вездный } \\
1429\end{array}$ & 31 & $\begin{array}{c}X \pm S x \\
\sigma \\
C v, \%\end{array}$ & $\begin{array}{c}176 \pm 16 \\
92 \pm 12 \\
52,2 \pm 6,6\end{array}$ & $\begin{array}{c}98 \pm 6 \\
35 \pm 4 \\
35,2 \pm 4,5\end{array}$ \\
\hline & Лав 7899 & 19 & $\begin{array}{c}\mathbf{X} \pm \mathbf{S x} \\
\sigma \\
\mathbf{C v}, \%\end{array}$ & $\begin{array}{c}292 \pm 44 \\
194 \pm 31 \\
66,5 \pm 10,8\end{array}$ & $\begin{array}{c}97 \pm 12 \\
52 \pm 8 \\
53,2 \pm 8,6\end{array}$ \\
\hline & $\begin{array}{c}\text { Неритон } \\
398411\end{array}$ & 19 & $\begin{array}{c}X \pm S \mathbf{S x} \\
\sigma \\
\mathbf{C v}, \%\end{array}$ & $\begin{array}{c}179 \pm 28 \\
126 \pm 20 \\
70,0 \pm 11,4\end{array}$ & $\begin{array}{c}122 \pm 14 \\
62 \pm 10 \\
50,6 \pm 8,2\end{array}$ \\
\hline & $\begin{array}{c}\text { Сатурн } \\
35201\end{array}$ & 71 & $\begin{array}{c}\mathbf{X} \pm \mathbf{S x} \\
\sigma \\
\mathbf{C v}, \% \\
\end{array}$ & $\begin{array}{c}153 \pm 10 \\
79 \pm 7 \\
51,5 \pm 4,5\end{array}$ & $\begin{array}{c}96 \pm 4 \\
38 \pm 3 \\
40,3 \pm 3,3 \\
\end{array}$ \\
\hline \multirow{4}{*}{$\begin{array}{c}\text { ООО } \\
\text { «Матвеевс } \\
\text { кое» }\end{array}$} & $\mid \begin{array}{c}\text { 3вездный } \\
1429\end{array}$ & 34 & $\begin{array}{c}\mathbf{X} \pm \mathbf{S x} \\
\boldsymbol{\sigma} \\
\mathbf{C v , \%}\end{array}$ & $\begin{array}{c}145 \pm 13 \\
71 \pm 9 \\
48,8 \pm 6,4\end{array}$ & $\begin{array}{c}111 \pm 11 \\
59 \pm 7 \\
53,0 \pm 6,7\end{array}$ \\
\hline & Лав 7899 & 10 & $\begin{array}{c}\mathbf{X} \pm \mathbf{S x} \\
\sigma \\
\mathbf{C v}, \% \\
\end{array}$ & $\begin{array}{c}173 \pm 27 \\
82 \pm 19 \\
47,5 \pm 11,2 \\
\end{array}$ & $\begin{array}{c}103 \pm 18 \\
57 \pm 13 \\
55,4 \pm 12,4\end{array}$ \\
\hline & $\begin{array}{c}\text { Неритон } \\
398411\end{array}$ & 30 & $\begin{array}{c}\mathbf{X} \pm \mathbf{S x} \\
\sigma \\
\mathbf{C v}, \%\end{array}$ & $\begin{array}{c}181 \pm 23 \\
119 \pm 16 \\
65,4 \pm 8,9\end{array}$ & $\begin{array}{c}111 \pm 12 \\
67 \pm 9 \\
60,1 \pm 7,9\end{array}$ \\
\hline & $\begin{array}{c}\text { Сатурн } \\
35201\end{array}$ & 20 & $\begin{array}{c}\mathbf{X} \pm \mathbf{S x} \\
\sigma \\
\mathbf{C v}, \% \\
\end{array}$ & $\begin{array}{c}138 \pm 17 \\
73 \pm 12 \\
53,1 \pm 8,6 \\
\end{array}$ & $\begin{array}{c}100 \pm 11 \\
49 \pm 8 \\
49,3 \pm 7,8\end{array}$ \\
\hline \multirow{4}{*}{$\begin{array}{c}\text { ОАО ПЗ } \\
\text { «Петровск } \\
\text { ое» }\end{array}$} & \begin{tabular}{|c|} 
3вездный \\
1429
\end{tabular} & 21 & $\begin{array}{c}\mathbf{X} \pm \mathbf{S x} \\
\sigma \\
\mathbf{C v}, \% \\
\end{array}$ & $\begin{array}{c}180 \pm 22 \\
101 \pm 15 \\
56,1 \pm 8,7\end{array}$ & $\begin{array}{c}158 \pm 20 \\
85 \pm 14 \\
53,4 \pm 9,2\end{array}$ \\
\hline & Лав 7899 & 15 & $\begin{array}{c}\mathbf{X} \pm \mathbf{S x} \\
\sigma \\
\mathbf{C v}, \%\end{array}$ & $\begin{array}{c}204 \pm 27 \\
105 \pm 19 \\
51,3 \pm 9,4\end{array}$ & $\begin{array}{c}197 \pm 44 \\
116 \pm 31 \\
58,8 \pm 15,7\end{array}$ \\
\hline & $\begin{array}{c}\text { Неритон } \\
398411\end{array}$ & 19 & $\begin{array}{c}\mathbf{X} \pm \mathbf{S x} \\
\sigma \\
\mathbf{C v}, \%\end{array}$ & $\begin{array}{c}193 \pm 31 \\
130 \pm 22 \\
67,3 \pm 11,5\end{array}$ & $\begin{array}{c}128 \pm 26 \\
96 \pm 18 \\
74,8 \pm 14,1\end{array}$ \\
\hline & $\begin{array}{c}\text { Сатурн } \\
35201\end{array}$ & 9 & $\begin{array}{c}\mathbf{X} \pm \mathbf{S x} \\
\boldsymbol{\sigma} \\
\mathbf{C v , \%}\end{array}$ & $\begin{array}{c}220 \pm 48 \\
145 \pm 34 \\
65,9 \pm 15,5\end{array}$ & $\begin{array}{c}109 \pm 22 \\
67 \pm 16 \\
61,6 \pm 14,5\end{array}$ \\
\hline
\end{tabular}

Среди всех коров наибольший сервис-период мы наблюдали у дочерей быка Лав 7899 в ОАО «Вохринка» - 292 дня, что достоверно выше чем у дочерей быков Звездный 1429, Неритон 398411и Сатурн 35201 в этом хозяйстве $(P>0,99)$ на 116, 113, 139 соответственно. При этом, средняя продолжительность сервис-периода в ОАО «Вохринка» составляет 182 дня.

Если считать, что половой цикл коров составляет 18-24 дня и, в современной зоотехнии, допустимы отклонения в продолжительности сервиспериода до 120 дней [1], то и эти величины потомки дочерей племенного быка Лав 7899 превосходят в 2 раза. Возникает вопрос о целесообразности использования таких коров, межотельный цикл которых составляет более 500 
дней. И это не одно животное, в хозяйстве 19 дочерей Лав 7899 показали такие результаты. В ООО «Матвеевское» наибольший сервис-период мы отметили у дочерей Неритона 398411 - 181 день. В ОАО ПЗ «Петровское» у дочерей Сатурна 35201 - 220 дней.

Оценивая сервис-период - как период от отела до плодотворного осеменения, дополнительно мы рассмотрели индиффреренс-период количество дней до первого осеменения. У тех же дочерей племенного быка Лав 7899 в ОАО «Вохринка» первая охота наблюдалась через 97 дней после отела. Это говорит о том, что для всех животных с такими отклонениями необходим либо индивидуальный ветеринарный подход, либо необходимо создать условия, когда животное при высокой продуктивности имело бы способность осеменяться (покрываться) в первую охоту [2]. Нами установлено, что практически все дочери высокопродуктивных племенных быков имеют проявление охоты в пределах 120 дней, однако поддержать стельность эти животные фризиологически не в состоянии. Организм этих животных требует отдыха и поэтому сервис-период достаточно высок.

\section{Список используемых источников:}

1. Державина, Г., Никитов, А., Ильин, А., Батракова, О. (2006). Продолжительность сервиспериода. Животноводство, (3), 47-48.

2. Петкевич, Н. (2005). Методы повышения воспроизводительной способности животных. Молочное и мясное скотоводство, (4), 11-12.

3. Сударев, Н. (2008). Удои и сервис-период взаимосвязаны. Животноводство России, (3), 49-51.

4. Федосеева, Н. (2007). Связь межотельного периода с молочной продуктивностью коров. Молочное и мясное скотоводство, (3), 22-23.

\section{СЕЛЕКЦІЙНА ОЦІНКА РІЗНИХ ГЕНОТИПІВ ПРИ НОВОЇ ПОПУЛЯЦІЇ МЯСНИХ СИМЕНТАЛІВ ЖУЙНИХ У ЗОНІ УКРАЇНСЬКИХ КАРПАТ}

Калинка Андрій Казимирович

канд. с.-г. наук., старший науковий співробітник

Буковинська державна сільськогосподарська дослідна станція НАAH

УКРАÏHA

Для забезпечення українського населення продуктами скотарства виконувалась програма про створення спеціалізованих порід худоби з високим генетичним потенціалом м'ясної продуктивності з отриманням дешевої та якісної яловичини у різних регіонах України.

В Західному регіоні України, зокрема на Буковині та Галичині, створюється нова популяція буковинського зонального типу м'ясного сименталу худоби 3 високим генетичним потенціалом молочної та мясної продуктивності, енергією росту в усіх фрізіологічних періодах вирощування, що є найбільш актуальним. 
Тому використовуючи досвід вітчизняної науки та досягнення закордонних практиків в нашій країні створюється українська симентальська м'ясна порода худоби, яка формується в різних ґрунтово-кліматичних зонах на материнській основі різних породних типів місцевих сименталів, обумовлених годівлею, особливостями місцевої худоби і спрямованістю відбору та пристосованістю для різних кліматичних зон Українських Карпат [1-4].

Згідно розробленої селекційної програми якісного перетворення місцевого буковинського типу симентальської породи комбінованого напрямку продуктивності з використанням вітчизняного та закордонного генофонду м'ясного сименталу різної селекції та ліній в господарствах Чернівецької області протягом 20-річної селекційної роботи (1999 - 2019 р.р.) із створенням масиву нової популяції буковинського зонального типу м'ясного сименталу худоби.

Мета роботи - селекційна оцінка нової створеної популяції м'ясних сименталів великої рогатої худоби в Карпатському регіоні України.

Основним джерелом для написання тез, послужили дані статистичної звітності, нормативні матеріали, дані власних наукових досліджень, літературні джерела, річні звіти зоотехніків селекціонерів досліджуваних базових та дочірніх господарств регіонів Буковини та Галичини.

Робота виконувалася в базових та дочірніх господарствах з розведення м'ясних сименталів нової популяції у племінному заводі ДП ДГ “ Чернівецьке " (151 корів) та в дочірніх господарствах СВПК „Перемога" (85корів) Герцаївського, ДП “Рокитне” СТОВ “Авангард” (65 корів) " ФГ «Іванківці» (31 корів), СВК «Зоря» (ЗОкорів) Кіцманського, Чернівецької та у ПФГ «Поточище» (95 корів) Городенківського, ТОВ «ТОРО» (45 корів) Галицького ТОВ Левада» (20 корів) Коломийського районів, ФГ «Заріччя» (10 корів) ПП «Богдан» (45 корів) Косівського районів Івано - Франківської областей на поголів'ї 1339 голів в тому числі 612 корів у різних зонах Карпат.

Дослідженнями визначено, що надалі селекція мясної худоби у створеному стаді ДПДГ „Чернівецьке” буде йти в напрямку консолідації 3 використанням наявного чистопородного маточного поголів'я для відтворення та розмноження тварин нової популяції створюваного буковинського зонального типу з кінцевим генотипом (СКан.3/4 САв. 1/8 СНім. $1 / 8$, САм.1/16) 3 розведення в різних кліматичних зонах Карпат. За результатами роботи визначено середню живу масу корів нової генерації сименталів худоби у племінному заводі ДП ДГ „Чернівецьке”, що у віці 5-7 років жива маса корів (121 гол.) склала у середньому 652 кг (2019 рік), що на 40 кг $(6,8 \%)$ більше за цей показник 2018 року.

Отже, при створенні нового генотипу (СКан. 3/4 САв. 1/8 СНім. 1/8 САм. 1/16) важливого значення надавали питанню формуванню структури стада за віком та живою масою тварин у племінному заводі ДП ДГ „Чернівецьке”. За результатами досліджень визначено живу масу в нащадків бугайців у найбільш продуктивному генотипі (СКан. 3/4САв. + 1/16 СНім. $1 / 8+$

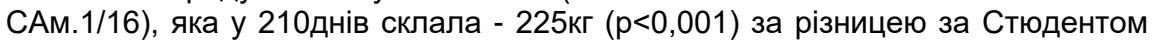
(td) у них складає - 2,92), найгірше - 3 кровністю іншою (СКан.3/4+ САв. $1 / 8+$ САм. $1 / 16)$ і менше $67 \%(\mathrm{td}=5,31)$, а нащадки з проміжним генотипом зайняли середнє положення $(\mathrm{td}=4,1)$ у стаді ДПДГ «Чернівецьке». 
Проведеними дослідженнями встановлено, що з підвищенням спадковості створюваного буковинського зонального типу м'ясного сименталу худоби нової популяції в продуктивному створеному новому генотипі (СКан. 3/4САв. + 1/16 СНім. 1/8 + САм. 1/16) збільшуються їх лінійні і масові габарити у яких жива маса зросла на $15,5 \kappa г$, висота в холці - на $3,1 \mathrm{~cm}$, обхват грудей - на $4,8 \mathrm{~cm}$, коса довжина тулуба і заду відповідно на 1,7 і 2,1, габаритні розміри - на $13,5 \mathrm{~cm}$.

При виконанні селекційної роботи виявлено, що інтенсивність росту в даному типі ремонтних телиць від народження до 7 місячного віку в новому продуктивному генотипі (СКан. 3/4САв. + 1/16 СНім. 1/8 + САм.1/16) - 15,7\%, які достовірно переважають на $3,4 \%(p<0,001)$ своїх поліпшених ровесниць генотипу (СКан. 25/32 + САв.- 1/16 +СНім.1/8 +САМ. 1/32). У проведених дослідженнях визначено кореляційний зв'язок у ремонтних телицях з кінцевим генотипом СКан. 3/4САв. + 1/16 СНім. 1/8 + САм.1/16 між живою масою у період вирощування був не високим та від'ємним - при народження $r=-0,13$ ( $>0,095) ; 7$ міс. $r=-0,02$ та у 12 місяців $r=-0,05$ ( $p>0,095)$.

У процесі виконання селекційно - племінної роботи, встановлено, що у продуктивному м'ясному стаді із створеними двома продуктивними генотипами у ДП ДГ «Чернівецьке» з віком спостерігається тенденція зниження відносних приростів живої маси тварин, що й було нами доведено. Так найнижчими вони були у нащадків 12-18 місяців у фізіологічному періоді розвитку тварин, який становив $(25,3 \%)$ у чистопорідних телиць генотипу СКан. 3/4САв. + 1/16 СНім. 1/8 + САм.1/16, що достовірно переважали на 4,5\% $(p<0,001)$ поліпшений генотип СКан. 25/32 + САв.- 1/16 +СНім.1/8 +САМ. 1/32.

В проведених дослідженнях за звітний період, визначили середню живу масу бугайців у різних лініях з дати народження до 7- місячного віку у ДП ДГ «Чернівецьке» де нащадки родоначальника бугая - плідника Фореста 0899 лінії Ахілеса 369 американської селекції, мали живу масу при відлученні від матерів годувальниць - 235 кг, що на - 24,9 кг (12,2\%) більше за ровесників Маскіта 1822 лінії Сигнала 120 австрійської селекції.

Проведення селекційної роботи у стаді племінного заводу ДП ДГ «Чернівецьке», вказує на те, що вже створені нові генотипи та їх лінійне генеалогічне поєднання найбільш трьох видатних головних продуктивних ліній буковинського зонального типу м'ясного сименталу худоби, а саме лінії Ахілеса 369, Абрікотта 58311, Сигнала 120, які мають високу продуктивність і транспортують свої природні гени комолості своїм нащадкам та збільшують енергію росту на $18-21 \%$ в умовах передгірської зони Карпатського регіону Буковини. Проведена оцінка телиць у генотипі (СКан. 3/4САв. + 1/16 СНім. 1/8 + САм.1/16), які отримані від бугаїв - плідників німецької селекції ( Мумбім 9214, Хаврош 9347, Бомбея 9212 та Матроса 9217, які характеризуються вищою скоростиглістю та віком запліднення, що на 23,5 доби коротший, ніж у доньок плідників минулого генотипу СКан.3/4+ САв.1/8САм.1/16.

Вивчили живу масу корів-первісток в базових господарствах (табл.1).

Аналіз даних (табл.1) дає підстави зробити висновок, що корови нової генерації м'ясних сименталів в господарствах за живою масою та молочністю, поступаються худобі ДП ДГ „Чернівецьке” за біометричними показниками. 
Жива маса і молочність корів-первісток

\begin{tabular}{|c|c|c|c|c|c|c|c|c|c|}
\hline \multirow{2}{*}{ № } & \multirow{2}{*}{ Господарство } & \multirow{2}{*}{ Райони } & \multirow{2}{*}{$\mathrm{n}$} & \multicolumn{3}{|c|}{ Жива маса, кг } & \multicolumn{3}{|c|}{ Молочність, кг (210днів) } \\
\hline & & & & $\mathrm{M} \pm \mathrm{m}$ & 6 & $\mathrm{CV}$ & $\mathrm{M} \pm \mathrm{m}$ & 6 & $\mathrm{CV}$ \\
\hline \multicolumn{10}{|c|}{ Чернівецька область } \\
\hline 1 & $\begin{array}{l}\text { ДПДГ “ } \\
\text { Чернівецьке ” }\end{array}$ & Герцаївський & 28 & 552 & 17,04 & 4,13 & 198,5 & 11,12 & 4,67 \\
\hline 2 & $\begin{array}{l}\text { ДП “ Рокитне " } \\
\text { СТОВ “Авангард " }\end{array}$ & Новоселицькй & 14 & 517 & 14,12 & 3,23 & 185,7 & 9,35 & 3,34 \\
\hline 3 & ФГ « Іванківці» & Кіцманський & 13 & 509 & 13,14 & 3,03 & 195,4 & 8,31 & 2,95 \\
\hline 4 & СВК « Зоря» & Кіцманський & 8 & 513 & 15,04 & 3,17 & 191,8 & 7,34 & 1,97 \\
\hline 5 & СВПК « Перемога» & Герцаївський & 15 & 495 & 14,06 & 3,56 & 187,6 & 8,75 & 2,31 \\
\hline \multirow[t]{2}{*}{6} & ТОВ « Зірка» & Заставнівський & 7 & 490 & 13,07 & 3,89 & 189,5 & 8,23 & 2,45 \\
\hline & \multicolumn{2}{|l|}{ Усього } & 85 & 512,7 & 14,41 & 3,51 & 191,4 & 8,85 & 2,95 \\
\hline \multicolumn{10}{|c|}{ Івано-Франківська область } \\
\hline 1 & TOB « Topo» & Галицький & 35 & 515 & 13,8 & 3,13 & 195,7 & 8,78 & 2,12 \\
\hline 2 & ФПГ « Поточище» & Городенківський & 18 & 500 & 12,3 & 2,89 & 195,5 & 9,12 & 1,97 \\
\hline 3 & ФГ « Заріччя» & Косівський & 10 & 495 & 15,7 & 3,15 & 187,3 & 8,92 & 2,45 \\
\hline 4 & ПП « Богдан» & Косівський & 15 & 490 & 14,3 & 2,87 & 191,5 & 8,15 & 2,56 \\
\hline 5 & АФ «Левада» & Коломийський & 7 & 500 & 11,7 & 2,31 & 197,5 & 8,75 & 1,97 \\
\hline \multicolumn{3}{|c|}{ Усього } & 85 & 502,5 & 13,37 & 2,87 & 194,1 & 8,89 & 2,12 \\
\hline \multicolumn{3}{|c|}{ У середньому } & 170 & 507,6 & 13,89 & 3,19 & 192,7 & 8,87 & 2,53 \\
\hline
\end{tabular}

За результатами досліджень росту телиць різних перспективних створених нових генотипів м'ясних сименталів худоби у яких встановлені певні відмінності, між собою у племінному заводі ДПДг „Чернівецьке” де жива маса телиць на дату народження становила у генотипі (симентал канадський 25/32 + симентал австрійський. - 1/16 + симентал німецький $1 / 8$ + симентал

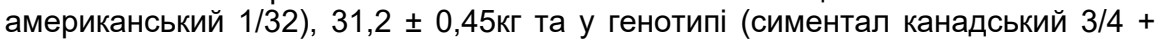
симентал австрійський $1 / 16+$ симентал німецький $1 / 8+$ симентал американський 1/16), 33,5 \pm 0,45 кг, 3-місячних - 89,2кг $\pm 1,25$ та 91,6 $\pm 1,37$ кг,

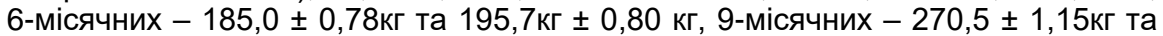

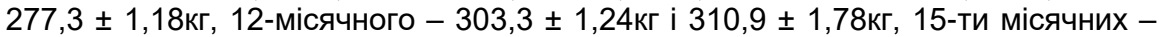
$325,5 \pm 1,35$ кг та $350,1 \pm 1,91$ кг, 18-ти місячних $-389,3 \pm 2,34$ кг та 405,8 $\pm 3,03$ кг відповідно.

У проведеній селекційній роботі було нами визначено різний відносний приріст живої маси телиць різних генотипів створюваного буковинського зонального типу м'ясного сименталу худоби у різних фрізіологічних періодах вирощування (табл.1).

Таблиця 2

Відносний приріст живої маси телиць

\begin{tabular}{|c|c|c|c|c|c|c|}
\hline \multirow{2}{*}{$\begin{array}{c}\text { Показ- } \\
\text { ник }\end{array}$} & \multicolumn{6}{|c|}{ Період, місяців } \\
\hline & $0-3$ & $3-6$ & $6-9$ & $12-15$ & $15-18$ & $0-18$ \\
\hline \multicolumn{7}{|c|}{$\begin{array}{c}\text { Генотип: симентал канадський 25/32 + симентал австрійський. - 1/16 + симентал німецький 1/8 } \\
\text { симентал американський 1/32 }\end{array}$} \\
\hline$x \overline{ \pm s} x$ & $115,2 \pm 2,35$ & $108 \pm 3,01$ & $32,5 \pm 0,65$ & $19,7 \pm 0,45$ & $9,8 \pm 0,41$ & $795,8 \pm 12,31$ \\
\hline $\mathrm{Cv}, \%$ & 24,3 & 26,7 & 18,6 & 29,8 & 41,3 & 12,8 \\
\hline \multicolumn{7}{|c|}{$\begin{array}{c}\text { Генотип:симентал канадський } 3 / 4+\text { симентал австрійський } 1 / 16 \text { + симентал німецький } 1 / 8+ \\
\text { симентал американський } 1 / 16\end{array}$} \\
\hline$X \pm S x$ & $135,6 \pm 3,45$ & $101,4 \pm 3,35$ & $30,3 \pm 0,45$ & $20,5 \pm 0,89$ & $11,4 \pm 1,06$ & $826,2 \pm 15,02$ \\
\hline $\mathrm{Cv}, \%$ & 22,6 & 25,7 & 15,7 & 40,7 & 51,6 & 11,7 \\
\hline
\end{tabular}


За відносним приростом живої маси ремонтні телиці найбільш продуктивного генотипу (симентал канадський $3 / 4+$ симентал австрійський 1/16 + симентал німецький 1/8 + симентал американський 1/16) переважали телиць генотипу (симентал канадський 25/32 + симентал австрійський. - 1/16 + симентал німецький 1/8 + симентал американський 1/32 за період від народження до 3-місячного віку на 7,3 \% (Р>0,99), від 9 - до 12-місячного - на $1,2$ \% ( $\mathrm{P}<0,95)$, від 12- до 15-місячного - на $15,4 \%$ ( $\mathrm{P}<0,95)$, від 15- до 18місячного - на $17,4 \%(\mathrm{P}<0,95)$ та від народження до 18-місячного віку - на 29,9 \% (P>0,99), лише в проміжках від 9 - до 12 - місячного віку кращі середні показники були зменшені і становили $1,2 \%(P>0,99)$ та 0,9 \% $(P<0,95)$.

Звертає на себе увагу дуже важливий виробничий показник з визначення середньодобових приростів у різних фізіологічних періодах від народження до 3-місячного віку досягали 612,1 \pm 0,0234 та 638,2 \pm 0,0286 кг, від 3 - до 6місячного - 1052,7 $\pm 0,0374$ та 1143,9 \pm 0,0311 кг, від 6- до 12-місячного - 653,6 $\pm 0,0314$ та 0,640 $\pm 0,0414$ кг, від 9 - до 12-місячного - 985,8 $\pm 0,0113$ та 960,0 $\pm 0,0241$ кг, від 12- до 15-місячного - 835,5 $\pm 0,0132$ та 808,1 $\pm 0,412$ кг, від 15до 18-місячного віку $-708,9 \pm 0,0293$ та $744,4 \pm 0,0552$ кг, а від народження до 18-місячного віку становили 795,8 \pm 0,0049 та 850,0 \pm 0,0068 кг відповідно.

За відносним приростом живої маси телиць м'ясного сименталу худоби переважав місцеву симентальську породу за період від народження до 3місячного віку на 15,1 \% ( $\mathrm{P}>0,99)$, від 9 - до 12-місячного - на $3,5 \%$ ( $\mathrm{P}<0,95)$, від 12- до 15-місячного - на 11,4 \% ( $\mathrm{P}<0,95)$, від 15- до 18-місячного - на 17,4 $\%(P<0,95)$ та від народження до 18-місячного віку - на $48 \%(P>0,99)$ та симентальську при ( $<<0,95)$ в умовах регіону Буковини.

При проведені досліджень доведено, що показники росту ремонтних телиць м'ясного комолого сименталу худоби у 18 місяців мають живу масу 395-405 кг; висоту в холці - 125-128 см; та 180,7 - 181,0 см обхвату грудей, жива маса повновікових корів становить 545-650 кг, що перевищує вагові та лінійні розроблені стандарти з індексом довгоногості, розтягнутості та грудного, при чому індекси розтягнутості і грудного були вищими - на 9,3 $(P<0,001), 3,9(P<0,001)$ та $0,7(P<0,05)$ і $7,6(P<0,001), 4,3(P<0,001)$ та $1,6 \%$ $(\mathrm{P}<0,001)$ відповідно.

Таким чином встановлено, що первістки-корови лінії Ахілеса 351 американської селекції, одержані від різних ліній мали значні відмінності за екстер'єром та величиною промірів, первістки ровесниць лінії Сигнала120 австрійської селекції за висотою в холці на 5 см $(5,6 \%)$, глибиною грудей - на 8-9 $(16,6 \%)$, широтними промірами на -3,8\%), на - $(6,1 \%)$, на - (16,9\%). У корів первісток лінії Ахілеса 351 за визначними промірами спостерігається подібна перевага над ровесниками інших ліній, які $є$ в стаді і мають, як правило досить крупні і масивні, пропорційної тіло будови й розвитку з висотою в холці $134,8 \pm 0,22$ см, з добре розвиненими глибокими $(71,3 \pm 0,15$ см) і широкими $(47,0$ $\pm 0,20$ см) грудьми при їх обхваті 195,4 \pm 0,42 см, живою масою 675,4 кг в умовах передгірської зони Карпатського регіону Буковини.

\section{Список використаних джерел:}

1. Калинка, А. К. Продуктивність нової популяції створюваного буковинського зонального типу м'ясного сименталу жуйних у Карпатському регіоні України. Таврійський науковий вісник: Науковий журнал, Вип. 105, 160-165. 
2. Ковтун С.І., Калинка А. К. \& Шпак Л. В. Продуктивність нової популяції м'ясних комолих сименталів жуйних з використанням різних селекцій та ліній в Карпатському регіоні України. Між. наук-прак. конфреренція «Аграрна наука та освіта в умовах Євроінтеграції» (20-21 березня 2019 р.), м. Кам'янець-Подільський). 2019. - С.227-231.

3. Калинка А. К. \& Шпак Л. В. М'ясні симентали нової популяції на Буковині. Problems and achievements of modern science : coll. of scientific papers "А'ГО International scientific-practical conf., Cork, May 6, 2019. Cork : NGO «European Scientific Platform», 2019, (5), 77-82.

4. Калинка А.К, Лесик О.Б., Шпак Л.В. \& Казьмірук Л.В. Популяція симентальської худоби в Карпатаx. Wiadomości o postępie naukowym $i$ rzeczywistych badaniach naukowych

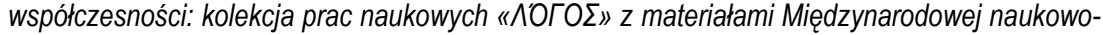
praktycznej konferencji, Kraków, 17 czerwca 2019 r. Kraków : OP «Europejska platforma naukowa», 2019, (3), 95.-100. 


\title{
APPRECIATING ECOLOGICAL DANGEROUS OF MUNICIPAL SOLID WASTE USING POLYNOMIAL APPROXIMATION
}

\author{
Ihor Lapyga \\ Ph.D. Pedagogical Sciences \\ National M.P. Dragomanov Pedagogical University
}

UKRAINE

Modern development of most world countries, more attention is paid to solving problems which appear with an increase in the number of predominantly urban population what exacerbation of many relevant environmental problems. The features of some from these problems are disclosed in previously published works $[1,2,3]$. This publication focuses attention on increasing the facts amount of insufficient accuracy ecological appreciating hazard of municipal solid waste, their impact on living organisms, the environment in urban residential areas. This problem is also relevant for Ukraine, where there is a high level of urbanization.

Literary sources analysis [4-8] showed that during years 2014-2018, the total volume of solid waste generated in Ukraine changed unevenly, but had a general tendency to decrease (Table 1).

Table 1

Municipal solid waste accumulation volume generated in Ukraine during years 2014-2018

\begin{tabular}{|l|c|c|c|c|c|}
\hline \multirow{2}{*}{ Solid Waste } & \multicolumn{5}{c|}{ Accumulation, } \\
\cline { 2 - 6 } & $\mathbf{2 0 1 4}$ & $\mathbf{2 0 1 5}$ & $\mathbf{2 0 1 6}$ & $\mathbf{2 0 1 7}$ & $\mathbf{2 0 1 8}$ \\
\hline Glass & 23,5 & 22,3 & 25,8 & 34,3 & 41,9 \\
\hline Paper and Cardboard & 234,2 & 111,0 & 184,5 & 183,5 & 146,1 \\
\hline Rubber & 25,3 & 22,9 & 20,3 & 26,4 & 21,9 \\
\hline Plastic & 43,7 & 42,9 & 51,9 & 48,6 & 47,2 \\
\hline Woody & 813,3 & 683,1 & 933,8 & 779,9 & 829,8 \\
\hline Electric Batteries & 6,3 & 7,2 & 4,0 & 4,1 & 3,8 \\
\hline Domestic & 7125,7 & 6789,2 & 9946,2 & 6183,2 & 6211,2 \\
\hline Total & 8272,0 & 7678,6 & 11166,5 & 7260,0 & 7301,9 \\
\hline
\end{tabular}

Prediction of municipal solid waste volumes, which are expected to be created in the coming years, is traditionally carried out using regression analysis methods and trends. The regression equation for the total volume of solid waste generated in Ukraine (see Table) takes the form:

$$
y=950,77 x^{4}-8 \cdot 10^{6} x^{3}+2 \cdot 10^{10} x^{2}-3 \cdot 10^{13} x+2 \cdot 10^{16} \text {, with } \mathrm{R}^{2}=1 .
$$

The trend line graphically displays the studied indicators' tendency with accuracy, which depends on the approximation reliability value, therefore it is 
important to choose the most effective approximation for each researched indicator. The linear approximation is mainly used, since it is the simplest.

In our research, to improve the accuracy amount of ecological appreciating MSW hazard was using a polynomial approximation with a degree of polynomial equal to 5 (Fig. 1).

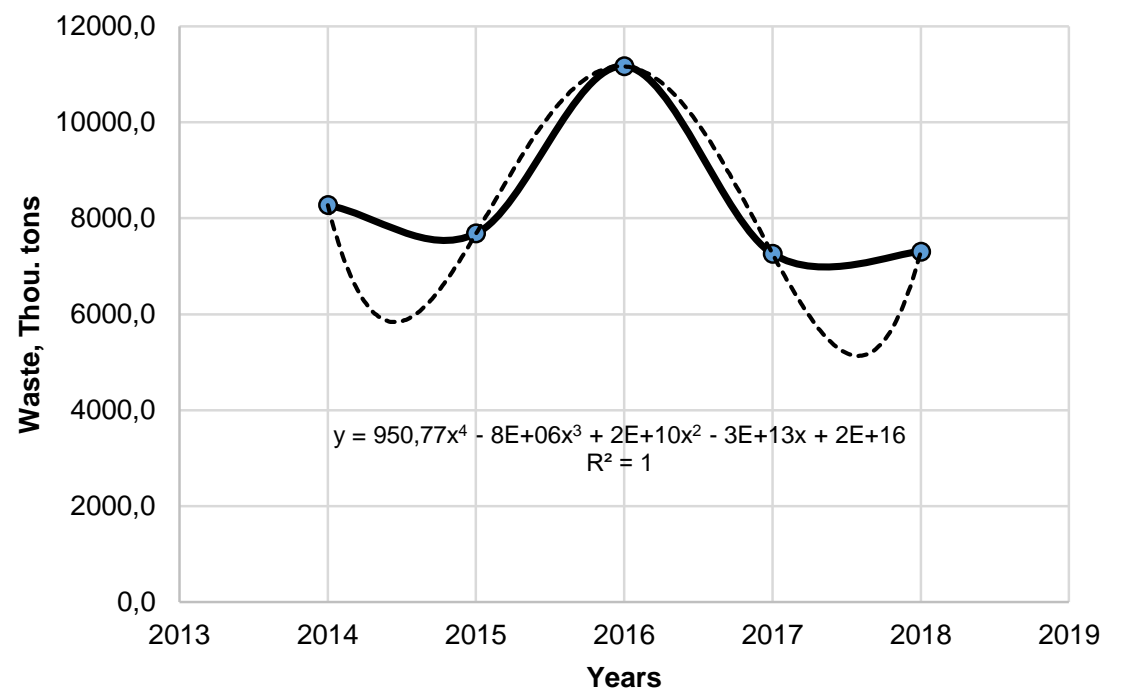

- Created wastes, thou. tons $\quad$------- Trend line

Fig. 1. Trend line total volume of municipal solid waste generated in Ukraine from the year 2014 to 2018

A comparative analysis of accuracy appreciating municipal solid waste ecological hazard using the indicated polynomial approximation showed that this approach is more effective (coefficient $R^{2}=1,0$ ), compared with the linear approximation method (coefficient $R^{2}=0,4$ ).

We believe that linear approximation it is advisable to use to reflect the values, that uniformly increase or decrease. The environmental hazard of the municipal solid waste impact can also be appreciating for indicators that change unevenly. A polynomial approximation with a degree of polynomial equal to five can provide the highest estimation accuracy.

\section{References:}

1. Lapyga, I. (2018). Condition Photosynthetic Apparatus of Acer Platanoides L. and Acer Tataricum L. on the Territory of Sanitary-Protective Zone "S. Kovalska RCS" in the City of Kyiv. In: Dev. Nat. Sci. Probl. Solut. Proc. Conf. Baltija Publishing, Brno, P. 89-93. Retrieved from https://is.gd/Ex30p3

2. Lichman, V.P., Lapyga, I.V. (2018). Status of Photosynthetic Apparatus Prunus Armeniaca L. at 
Changes of Lights Intensity on the Territories whith Higest Buldings in the City of Kyiv, 100-102. Retrieved from https://is.gd/hWsBn7

3. Hosam. M.S., Koller, M. (2019). Introductory Chapter: Municipal Solid Waste. In: Munic. Solid Waste Manag., (1). Retrieved from https://u.to/w03LFg

4. Жук, І.М. (2015). Статистичний щорічник України за 2014 рік. Державна служба статистики України.

Вилучено

https://ukrstat.org/uk/druk/publicat/kat_u/2015/zb/10/zb_2014_ukr.zip

5. Жук, І.М. (2016). Статистичний щорічник України за 2015 рік. Державна служба статистики України. Вилучено 3 https://ukrstat.org/uk/druk/publicat/kat_u/2016/zb/11/zb_2015_ukr.zip

6. Вернер, І.Є. (2017). Статистичний щорічник України за 2016 рік. Державна служба статистики України.

Вилучено https://ukrstat.org/uk/druk/publicat/kat_u/2017/zb/11/zb_seu2016_u.zip

7. Вернер, І.Є. (2018). Статистичний щорічник України за 2017 рік. Державна служба cтатистики України.

Вилучено 3 https://ukrstat.org/uk/druk/publicat/kat_u/2018/zb/11/zb_seu2017_u.pdf

8. Вернер, І.Є. (2019). Статистичний щорічник України за 2018 рік. Державна служба статистики України. Вилучено http://www.ukrstat.gov.ua/druk/publicat/kat_u/2019/zb/11/zb_yearbook_2018.pdf

\title{
ЗАСТОСУВАННЯ КОНЦЕПЦІЇ МІЖОРГАНІЗАЦІЙНОЇ СУМІСНОСТІ І ВЗАЄМОДІЇ В ІНФОРМАЦІЙНИХ СИСТЕМАХ ОРГАНІВ ПУБЛІЧНОГО УПРАВЛІННЯ У КОНТЕКСТІ ДОСВІДУ ШВЕЦІї
}

\begin{abstract}
Андрієнко Антон Олегович
аспірант

Дніпропетровський регіональний інститут державного управління Національної академії державного управління при Президентові України

УКРӒ̈̈А
\end{abstract}

Розглянемо міжорганізаційні інформаційні системи (IC) в процесі здійснення електронного урядування, зокрема, IT-комунікацій, в Швеції. Міжорганізаційні IC тут вважаються інструментами налагодження обміну інформацією між органами публічного управління всіх рівнів - від державного (центральні органи) до місцевого (місцеве самоврядування). Досвід Швеції засвідчив, що доволі ефективною протягом багатьох років поспіль $€$ практика залучення також і інших типів міжорганізаційних елементів: державні органи можуть співпрацювати на різноманітних цифрових ресурсах у широкому спектрі їх видів (спільні веб-сайти, спільні IT-компоненти, спільні бек-офісні системи).

Проте, базовими вважаються 4 типи побудови міжорганізаційних IC. Відповідно, міжорганізаційний обмін інформацією відбувається на базі концепції міжорганізаційної сумісності. Вона, в свою чергу, має чотири рівні: 
нормативно-правовий, організаційний, логічно-смисловий та технічний. Ця концепція також здобула назву «електронного співуправління», яка вписує її в рамкові межі 7 «співуправлінських» вимірів: нормативний, регуляторний, перформативний або виконавчий, реляційний, семантичний, презентаційний та технічний [5].

Таким чином, 4 типи моделей міжорганізаційного електронного уряду та 7 міжорганізаційних співуправлінських вимірів $€$ основними частинами концептуальної основи електронного уряду Швеції.

Управління міжорганізаційною взаємодією, обміну документами та іншою інформацією на рівні органів публічного управління вважається багаторівневим та багатовимірним завданням. Для пошуку кращих організаційних і технічних рішень в цій сфері працюють та взаємодіють одразу декілька державних агенцій та громадських організацій, що співпрацюють між собою заради «модернізації та постійного оновлення системи використання спільного цифрового ресурсу» органами влади [5]. Налагодження співробітництва між державними агенціями та громадськими організаціями щодо спільної розробки цифрових продуктів у вигляді електронних ресурсів вважається однією з найважливіших вимог у здійсненні належного публічного управління Швеції [2; 3].

Важливою передумовою розробки програмних продуктів для обміну інфрормацією між державними органами Швеції $\epsilon$ налагодження роботи системи обміну інформацією між державними агентствами та доступ до цих ресурсів для громадських організацій [2; 6]. Установи і організації взаємодіють між собою через загальні веб-сайти або програмні IT-компоненти різних видів. При цьому, здійснюється розмежування між ресурсами фронт-офрісу та бекофрісу як двома основними категоріями цифррових ресурсів. Так, фронт-офрісні цифрові ресурси призначені для безпосереднього використання зовнішніми користувачами (громадські організації та громадяни), бек-офрісні - для внутрішнього використання в межах державного органу чи органів (тільки внутрішніми працівниками).

Відповідно, існує чотири категорії міжорганізаційних цифрових ресурсів:

- спільний веб-сайт (функціональний компонент фронт-офісу, що складає загальну цифрову ресурсну систему для органів-учасників. Його розроблення та підтримка вимагають співпраці між залученими органами. На ньому різні види інформації та пропонованих послуг розміщуються на ресурсі спільного доступу та $\epsilon$ доступними для всіх користувачів за умов досягнення максимального ступеню інтеграції діяльності різних органів публічної влади на одному веб-сайті [6]);

- спільний цифровий компонент веб-сайтів (вбудовані IT-компоненти, які $\epsilon$ загальними / спільними цифровими ресурсами для кількох державних установ. Наприклад, компоненти загальної аутентифрікації користувачів, які використовуються декількома органами публічної влади);

- обмін інформацією між інституціями (коли в державній установі центрального рівня або між двома установами існує цифровий зв'язок, між цими установами виникає «спільний цифровий інтерес». Якщо мова йде про одну чи 2 установи, які обмінюються інформацією, координація відносно проста. Але якщо задіяно декілька установ-учасників такої взаємодії, ситуація щодо координації роботи зі спільної розробки та управління цифровими ресурсами ускладнюється. Цифрровий обмін інформацією може здійснюватися 
різними способами: «машина - машина», тобто прямий зв'язок між ITсистемами різних інституцій, або «людина - машина», тобто залучення людини через цифровий інтерфейс користувача, яка надсилає інфрормацію або отримує інформацію з ІТ-системи іншої інституції);

- загальна IT-система (як зазначено, є приклади загальних веб-сайтів та веб-компонентів. У цих випадках між інституціями налагоджена співпраця щодо приймання фронт-рішень. Однак $є$ кілька прикладів подібних цифрових функцій у внутрішньоорганізаційних операціях (бек-офріс). Особливо це характерно для органів місцевого самоврядування. У них існують подібні практичні завдання, засновані на загальній місії та загальному наборі правил. Стандартний режим роботи означає, що доцільно використовувати подібні, або навіть спільні IT-системи) [5].

Перші 2 категорії мають фронт-офрісний характер, останні 2 - бек-офісний. Далі перейдемо від названих чотирьох рівнів сумісності до семи аспектів співпраці. Сумісність в цифровій взаємодії означає здатність організацій / систем працювати разом. Чотири рівні інтероперабельності зазвичай включають: правову, організаційну, семантичну та технічну [1; 3; 4]. Правова сумісність означає, що взаємодія може відбуватися в межах спільних законодавчих норм. Організаційна сумісність означає, що взаємодії можна досягти за рахунок ефективних робочих процесів та чіткого розподілу відповідальності між сторонами (учасниками обміну інформацією). Семантична сумісність - це сумісність шляхом загальної визначеної мови. Технічна сумісність означає, що взаємодія може відбуватися в безпечний і точний спосіб за допомогою технічних компонентів (табл. 1).

Таблиця 1

Типи сумісних взаємоінтегрованих цифрових ресурсів, що використовуються органами публічного управління Швеції

\begin{tabular}{|c|c|c|}
\hline Цифровий ресурс & Тип ресурсу e-gov & Галузь \\
\hline $\begin{array}{c}\text { Загальна система, що використовується } \\
\text { для документообігу та обміну інформацацією } \\
\text { в академічних закладах } \\
\end{array}$ & $\begin{array}{l}\text { Загальна бек-офісна } \\
\text { система }\end{array}$ & $\begin{array}{l}\text { Вища освіта i } \\
\text { наука }\end{array}$ \\
\hline Національний портал охорони здоров'я & Спільний веб-сайт & \multirow[b]{2}{*}{$\begin{array}{l}\text { Охорона } \\
\text { здоров'я }\end{array}$} \\
\hline $\begin{array}{c}\text { «Електронний рецепт» - обмін } \\
\text { інформацією } \\
\text { між медичними закладами (безпосередньо } \\
\text { лікарі) та аптеками } \\
\end{array}$ & $\begin{array}{l}\text { Обмін інформацією, } \\
\text { спільна бек-офісна } \\
\text { система }\end{array}$ & \\
\hline $\begin{array}{l}\text { Обмін інформацією в системі закладів } \\
\text { надання соціальної допомоги }\end{array}$ & $\begin{array}{c}\text { Обмін інформацією, } \\
\text { спільна бек-офісна } \\
\text { система }\end{array}$ & $\begin{array}{l}\text { Соціальна } \\
\text { допомога }\end{array}$ \\
\hline $\begin{array}{c}\text { Спільна система прийому до } \\
\text { закладів середньої освіти }\end{array}$ & $\begin{array}{c}\text { Спільний веб-сайт, } \\
\text { інформаційний обмін, } \\
\text { спільна відкрита система }\end{array}$ & Освіта \\
\hline $\begin{array}{c}\text { Спільна система передачі повідомлень та } \\
\text { забезпечення зворотного зв'язку з } \\
\text { громадянами } \\
\end{array}$ & $\begin{array}{c}\text { Спільний веб-сайт, } \\
\text { загальний цифровий } \\
\text { компоненти на веб-сайтах }\end{array}$ & Різні галузі \\
\hline $\begin{array}{c}\text { Платформи для муніципальних } \\
\text { електронних послуг (за заявами від } \\
\text { громадян). } \\
\end{array}$ & $\begin{array}{l}\text { Спільні цифрові } \\
\text { компоненти }\end{array}$ & $\begin{array}{l}\text { Муніципальні } \\
\text { служби }\end{array}$ \\
\hline
\end{tabular}


Продовження табл. 1

\begin{tabular}{|c|c|c|}
\hline Цифровий ресурс & Тип ресурсу e-gov & Галузь \\
\hline & $\begin{array}{c}\text { веб-сайтів муніципальних } \\
\text { служб, офрісів за принципом } \\
\text { «єдиного вікна» }\end{array}$ & \\
\hline $\begin{array}{c}\text { Національний портал посилань та ресурсів } \\
\text { для бізнесу }\end{array}$ & Спільний веб-сайт & $\begin{array}{c}\text { Галузь підтримки } \\
\text { бізнесу }\end{array}$ \\
\hline
\end{tabular}

Таким чином, шведський досвід демонструє застосування концепції міжорганізаційної сумісності і взаємодії в інфрормаційних системах органів публічного управління різного рівня та галузей діяльності. Виділяються чотири типи міжорганізаційних ресурсів електронного уряду: спільні веб-сайти, спільні цифрові компоненти веб-сайтів, обмін інформацією між інституціями, загальні IT-системи. Завдяки ним міжорганізаційне електронне управління та електронний документообіг $€$ досконалішим та більш функціональним, ніж просто обмін інформацією. Міжорганізаційне електронне врядування та обмін інформацією слід розглядати як спільний інтерес до спільних цифрових ресурсів, тобто «спільних цифрових проблем», що мають злагоджено вирішуватися публічною владою.

Якість процесу обмін інформацією в Швеції характеризується поняттям сумісності в ії різнорівневості. Концепція міжорганізаційної сумісності і взаємодії або інтероперабельності в інформаційних системах органів публічного управління розглядається в 7 вимірах: цілі та значення взаємодії (нормативний вимір), загальні правила (нормативний вимір), ролі учасників та їх відносини (реляційний вимір), робочі процеси та процедури (перформативний вимір), мова та значення (смисловий вимір), організація та репрезентація на інтерфейсах користувача (презентаційний вимір), структура та відносини між цифровими компонентами (технічний вимір).

Ця шведська концепція міжорганізаційної сумісності і взаємодії в інформаційних системах органів публічного управління може бути застосована в Україні, зокрема, в системах електронного документообігу та інформаційного обміну в органах публічної влади як державного, так і місцевого рівнів.

\section{Список використаних джерел:}

1. Bigdeli, Z., Kamal, M. \& deCesare, S. (2013). Inter-Organisational Electronic Information Sharing in Local G2G Settings: A Socio-Technical Issue. 19th European Conference on Information Systems, Helsinki.

2. Swedish Government Official Report SOU 2013:75. (2013). E-Government Delegation: Organisering av framtidens e-förvaltning. [in Swedish].

3. European commission. (2010). European Interoperability Framework (EIF) for European public services.

4. Goldkuhl, G., Eriksson, O., Persson, A. \& Röstlinger, A. (2014). Offentliggemensamma digitala resurser: Utmaningar i samstyrning och samanvändning inom svensk e-förvaltning. RESONANS slutrapport, Department of Management \& Engineering, Linköping University. [in Swedish]

5. Goldkuhl, G. \& Röstlinger, A. (2015). Inter-organisational e-government: From four levels of interoperability to seven dimensions of co-governance. The 12th Scandinavian Workshop on E- 
46 • Problèmes et perspectives d'introduction de la recherche scientifique innovante $\bullet$ Volume 2

government, February 3-4, 2015, Copenhagen. Retrieved from https://pdfs.semanticscholar.org/6704/aa2512e100a609f6ba01ce679afebc149481.pdf.

6. Klievink, B. \& Janssen, M. (2009). Realizing joined-up government - Dynamic capabilities and stage modelsfor transformation, Government Information Quarterly, (26), 275-284.

\section{СПІНДОКТЕРІНГ - СУЧАСНА ТЕХНОЛОГІЯ В ДЕРЖАВНОМУ УПРАВЛІННІ}

Адамовська Вікторія Сергіївна канд. екон. наук, доцент, доцент кафедри обліку, оподаткування, публічного управління та адміністрування Криворізький національний університет

Карпутенко Анастасія Ігорівна здобувач вищої освіти фракультету економіки та управління бізнесом Криворізький національний університет

УКPÄ̈HA

На сьогодні, на ринку праці відбуваються стрімкі зміни, які потребують сучасних та перспективних професій. Такі зміни супроводжуються швидким розвитком глобальних технологій: новітні професії приходять на зміну старим, які відповідають вимогам сучасного світу.

Для того, щоб дослідити дану тему, необхідно почати з визначення поняття «спіндокторінг». 3 англійської, слово «spin» означає «вертіння», «кружляння», a doctor - «лікування» [1]. Спіндокторінг - технологія маніпуляцій громадською думкою з арсеналу чорного піару, що застосовує підтасовування відомостей, спотворення фактів, масові публікації в авторитетних виданнях завідомо неправдивого подання реальних подій [2].

Частина фрахівців зв'язків із громадськістю використовують поняття «спіндокторинг» як окремо взяту запропоновану послугу, інші використовують такі терміни як «трансформація стратегії» або «перетворення зображення».

Виходячи з цього, ми можемо обґрунтувати актуальність вибраної теми тим, що продуктивне фрункціонування політичної організації залежить від того, як демонструються новини про неї в засобах масової інформації. На сучасному етапі, мас-медіа виступають найпотужнішим чинником впливу на розуміння людини опублікованої інформації. Кожна людина має можливість швидко ознайомитись з інформацією, проаналізувати ії та скласти власне бачення про іï зміст. Саме таке інформування впливає на імідж і репутацію організації. Політики, часто звинувачувані опонентами в нечесності, використовують тактику «спіна», щоб маніпулювати громадською думкою. Одна із найпоширеніших назв спеціалістів, які розвивають спіндокторінг, «спіндоктори».

Специфріка діяльності спіндокторів полягає у тому, що вони використовують інформацію як головний засіб впливу на громадськість. Тобто контролюючи інформаційні потоки, спіндоктори управляють новинами. У своїй діяльності спіндоктор може використовувати такі стратегії: 
1. Тоталітарну (варіант радянської системи) - введення повного контролю за інформацією в засобах масової інформації (далі - 3Мl), починаючи 3 найвищого рівня й до нижчих.

2. Демократичну (варіант західної системи) - за допомогою інтелектуальних 3MІ та їхньої динамічності. У цій моделі заборонені заходи використовують лише в певних випадках (війна, тероризм) [3].

Таким чином, діяльність спіндокторів можна визначити як технологію коригування новин, які отримали негативне сприймання громадськістю або як засіб маніпулювання інформацією.

При коректному використанні спіндокторінга можна виділити такі типи організації комунікації: ефективні та результативні. У публічному управлінні така технологія займає особливе місце. Із розвитком демократії паралельно розвивається таке явище як прозорість влади, воно дає можливість доступу кожному громадянину до інформації, яка стосується особистих інтересів громадянина або $є$ суспільним інтересом; дає можливість кожному контролювати виконання своїх обов'язків державними органами, посадовими особами тощо.

Проаналізувавши вітчизняну літературу, можемо дійти висновку, що в Україні не широко використовується сучасна технологія менеджменту інформацією як спіндокторінг. Досить часто вона застосовується як засіб коригування інфоомації у ЗМІ після того, як вона отримала негативне сприймання громадськістю. Зазвичай, діяльність спіндокторів застосовується у публічному управлінні, під час співпраці з державними органами влади та фокусується на особистому професіоналізмі спеціаліста (авторитет, особисті знайомства з журналістами, тощо).

Таким чином, 3 огляду на проведені дослідження пропонуємо використовувати зарубіжний досвід роботи спіндокторів. Наприклад, досвід роботи американських спіндокторів. Вже досить довго їхні державні установи, при контролі зовнішньої політики країни застосовують технологію спіндокторінгу, якою керуються в своїй роботі спеціальні ПР-підрозділи. До структури Держдепартаменту США відносять кілька офрісів та бюро, головною метою яких є захист інтересів власної держави, а також піклування про її авторитет. Досягають своєї мети за допомогою різних інструментів, методів та способів.

Отже, можна дійти висновку, що в Україні потрібно розширювати використання технології спіндокторінгу, адже за допомогою технології спіндокторінга можуть розширюватися можливості PR-менеджменту, який спеціалізується в галузі контролю над відображенням новин. До його функцій належать виправлення висвітлених подій у $3 \mathrm{MI}$ та надання потрібного сенсу новин і забезпечення позитивного ставлення до них. Усе це дозволить збільшити довіру громадян до органів державного управління завдяки прозорості інформації, її повноти та достовірності.

\section{Список використаних джерел:}

1. Spindoktor.

Retrieved from https://uk.wikipedia.org/wiki/\%D0\%A1\%D0\%BF\%D1\%96\%D0\%BD\%D0\%B4\%D0\%BE\%D0\%B $\mathrm{A} \% \mathrm{D} 1 \% 82 \% \mathrm{D} 0 \% \mathrm{BE} \% \mathrm{D} 1 \% 80$ [in Ukrainian]. 
2. Spindoktoring. Retrieved from http://promo-sa.ru/seoterms/spindoktoring [in Ukrainian].

3. Kotler, F. (2010). Spindoktor - likar chernogo PR [Spindoctor - doctor black PR]. Retrieved from http://www.bci-marketing.aha.ru/content/spindoktor-vrach-chernogo-pr [in Ukrainian].

DOI 10.36074/29.11.2019.v2.04

\section{ТЕОРЕТИЧНІ АСПЕКТИ РЕАЛІЗАЦІЇ ІННОВАЦІЙНОЇ МОДЕЛІ УПРАВЛІННЯ ЗАКЛАДОМ ВИЩОЇ ОСВІТИ}

Соколова Ельміра Тельманівна

аспірант 1 курсу за спеціальністю «Публічне управління та адміністрування»

КЗВО «Дніпровська академія неперервної освіти»

Науковий керівник: Братаніч Борис Володимирович доктор філософських наук, професор кафедри психології

КЗВО «Дніпровська академія неперервної освіти»

УКРАÏHA

Забезпечення інноваційної орієнтації розвитку закладів вищої освіти гарантує ефективну підготовку випускників, підвищення рівня інтегрованості освітніх послуг у сучасний ринок праці. Відповідно до актуальних соціальноекономічних умов стратегія публічного управління закладами вищої освіти має реалізовуватися з урахуванням інноваційного потенціалу конкретної установи. Актуальність проблеми реалізації інноваційної моделі управління закладом вищої освіти визначається постійним зростанням вимог суспільства до освіти в цілому, бурхливим розвитком високих і тонких технологій, взаємної інтеграції теоретичних і прикладних завдань відповідно до глобалізаційних тенденцій.

Основними функціями управління інноваційної моделі закладу вищої освіти науковці називають інформативну, мотиваційну, розвивальну, координаційну. Сучасний освітній процес неможливий без інноваційного оновлення, залучення нових технологій, апробації й адаптації відповідно до змісту освіти. Аналіз освітніх систем закладів вищої освіти з погляду розвивального потенціалу і проєктування всіх складових освітнього простору - один із найважливіших напрямів і ресурсів якості сучасної освіти. Особливу роль на сучасному етапі реформування управління освітою відіграє механізм подолання труднощей у досягненні цілей модернізації відповідно до загальноєвропейських та світових стандартів. Подолання протиріччя між масовим характером освіти та її особистісно-зорієнтованим змістом, між стандартами навчання та цінностями самовираження в самореалізації майбутніх випускників, їхньої конкурентоспроможності на ринку праці.

На діагностико-концептуальному етапі дослідження здійснено аналіз понятійно- категоріального апарату й термінології. Так, відповідно до Закону України «Про інноваційну діяльність» та положення «Про порядок здійснення інноваційної освітньої діяльності» термін «інноваційне управління навчальними закладами» визначається через поняття «інновація» та «освітня інновація». Термін «інновація» вперше був введений Й.Шумпетером у 1912 році у праці «Теорія економічного розвитку», тобто визначено економічною 
категорією. Найбільш доцільним в контексті взаємозв'язку управлінських освітніх процесів з інноваційною діяльністю є використання поняття «інновації» як форми керованого розвитку та цілеспрямованих змін, які вносять в середовище впровадження нових стабільних елементів. Таким чином під «інноваційним управлінням» слід розуміти нові та (або) вдосконалені організаційно-технічні рішення адміністративного характеру, які здатні істотно поліпшити функціонування усієї освітньої організації.

До внутрішніх чинників застосування інноваційного управління слід віднести необхідність у підвищення ефективності та результативності роботи закладу вищої освіти, застосування оперативних управлінських рішень, швидкого коригування планів, управління освітньою організацією як відкритою соціально-економічною системою, залучення інвестицій, забезпечення стабільного функціонування та сталого розвитку [1].

Рівень інноваційного управління слід визначати в залежності від змін та їхніх масштабів До основних завдань впровадження інноваційного шляху розвитку управління закладом вищої освіти відносять розробку і реалізацію оновленої корпоративної стратегії, оволодіння сучасними управлінськими технологіями, реалізацію заходів щодо підвищення ефективності працівників закладів вищої освіти, створення нових організаційних форм управління, прогнозування стратегічного розвитку та сталого функціонування закладу вищої освіти.

Наразі у науковій літературі досить широко висвітлено сутність і зміст основних теорій, концепцій і моделей організації управління, що задіяні в реалізації державної політики та широко застосовуються у світовій управлінській практиці. Результати дослідження концептуальних засад сучасного менеджменту виявили низьку ефективність і слабкість авторитарних методів управління, які ще домінують у діяльності організаційних формувань на постсоціалістичному просторі, де Україна не є винятком. До інноваційних для української освіти, а також таких, що мають певну перспективу на теренах нашої держави, на нашу думку, належать наступні концепти: ліберальна парадигма управління освітою, аксіологічна парадигма управління освітою (В. В. Крижко); синергетична парадигма управління освітою (В. Г. Буданов, В. Г. Кремень); саморегуляційна парадигма освіти (В.П. Бех) [2].

Таким чином, здійснений теоретичний аналіз свідчить про те, що реалізація інноваційної моделі управління полягає у визначенні перспективних напрямів розвитку відповідно до конкретних умов та особливостей закладу вищої освіти, у приведенні в дію інноваційного потенціалу, у розробці і впровадженні оновленого змісту, форм і засобів освітнього процесу. Поява нових навчальних систем, зокрема кредитно-трансферної, ступеневої, розвивальної, профільної) і впровадження інноваційних компонентів безпосередньо до змісту освіти здатні гарантувати сталий розвиток для закладів вищої освіти.

\section{Список використаних джерел:}

1. Кірдан, О. Л. Управління вищими навчальними закладами на зламі тисячоліття: генезис поглядів Управління навчальними закладами: досвід, проблеми, перспективи: збірник матеріалів Міжнародної науково-практичної конфреренції (с. 79-81). 2012, Одеса, Україна.

2. Антохов, О. А. \& Саєнко, О.С. (2013). Розвиток управління освітніми інноваціями у системі підготовки студентів. ВНЗ Вісник ОНУ ім. І.І. Мечникова (18), 172-177. 


\section{ТЕРИТОРІАЛЬНА ГРОМАДА ЯК ПЕРВИННИЙ СУБ'ЄКТ МІСЦЕВОГО САМОВРЯДУВАННЯ: СУТНІСТЬ ТА ФУНКЦІЇ}

Архипенко Світлана Вікторівна
канд. екон. наук, доцент, доцент кафедри обліку, оподаткування,
публічного управління та адміністрування
Криворізький національний університет

Почужевська Юлія Леонідівна магістрант фракультету економіки та управління бізнесом Криворізький національний університет

УКPAÏHA

Соціально-економічний розвиток України значною мірою залежить не лише від ефективної діяльності центральних органів влади, а й від діяльності регіональної державної влади та органів місцевого самоврядування. Місцеве самоврядування в цьому аспекті заслуговує на особливу увагу, бо саме на цьому рівні $€$ можливим поєднання інтересів держави (влади) і суспільства (народу). Саме на місцевому рівні реалізуються завдання державної політики та здійснюється власна політика територіальних громад [1].

Конституцією України проголошено, що «місцеве самоврядування в Україні - це гарантоване державою право та реальна здатність територіальної громади - жителів села чи добровільного об'єднання у сільську громаду жителів кількох сіл, селища, міста - самостійно або під відповідальність органів і посадових осіб місцевого самоврядування вирішувати питання місцевого значення в межах Конституції та законів України» [2].

Носієм місцевого самоврядування $€$ колектив людей, об'єднаний за територіальною ознакою, тобто територіальний колектив. У Конституції України 1996 р. територіальний колектив названо територіальною громадою.

Територіальна громада є первинним суб'єктом місцевого самоврядування, основним носієм його функцій і повноважень, тобто найбільш повноважним елементом системи місцевого самоврядування. Територіальна громада жителі, об'єднані постійним проживанням у межах села, селища, міста, що є самостійними адміністративно-територіальними одиницями, або добровільне об'єднання жителів кількох сіл, що мають єдиний адміністративний центр.

Значний відрізок часу громадське самоврядування здійснювалося на основі звичаєвого права. Нинішня територіальна громада в Україні не $є$ аналогом її історичного прообразу. На відміну від простої територіальної одиниці, поселення, що має статус територіальної громади, наділяється певними правами. Насамперед, це право на самоврядування.

Законодавством України закріплені такі основні ознаки територіальної громади [1]:

1. Територіальна - спільне проживання осіб, які входять у громаду на певній території;

2. Інтегративна - територіальна громада виникає на основі об'єднання всіх жителів, які мешкають на певній території незалежно від того, чи є вони громадянами даної держави, тобто членами територіальної громади можуть 
бути громадяни даної держави, а також іноземні громадяни, особи без громадянства, котрі постійно мешкають на певній території. Можливе включення до територіальної громади біженців і переміщених осіб;

3. Інтелектуальна - в основі формування територіальної громади лежать спільні інтереси жителів, які мають специфічний характер системних індивідуально-територіальних зв'язків;

4. Майнова - територіальна громада $€$ суб'єктом права комунальної власності. Їй належить рухоме і нерухоме майно, прибутки місцевих бюджетів, інші кошти, земля, природні ресурси, що перебувають у власності відповідних територіальних громад (ч.1 ст. 142 Конституції України);

5. Фіскальна - члени територіальної громади є платниками місцевих податків і зборів (ст. 67 Конституції України; Податковий кодекс України).

Діапазон функцій, які здійснюють територіальні громади дуже широкий. Система функцій територіальних громад аналогічні функціям держави, і властиві виключно або переважно суб'єктам місцевого самоврядування.

До основних функцій територіальних громад відносять такі [1]:

1. Політичну функцію - виявляється в забезпеченні реалізації громадянами конституційного права брати участь в державних і суспільних справах. До відання самоврядування відносяться лише ті функції, які держава може делегувати без загрози її політичної єдності.

2. Економічну - спрямована на створення локального сектору економіки. Полягає у вирішенні економічних питань місцевого значення, у т.ч. у виконанні програм соціально-економічного розвитку; управлінні комунальної власності, місцевих фінансів тощо;

3. Соціально-культурну - вирішення соціально-культурних питань місцевого значення. До відання місцевого самоврядування віднесено управління установами освіти, охорони здоров'я, культури, які належать територіальному колективу.

4. Екологічну - створення місцевих програм а також участь у загальнодержавних i регіональних програмах охорони навколишнього середовища.

Зокрема, економічна функція передбачає, що територіальна громада, здійснюючи свою діяльність, утворює економічну та фінансову систему.

\section{Список використаних джерел:}

1. Гуторова, О. (2017). Територіальне управління. Харків: ХНАУ.

2. Конституція України. № 254к/96-ВР. (2019). Вилучено 3 https://zakon.rada.gov.ua/laws/main/254\%D0\%BA/96-\%D0\%B2\%D1\%80. 


\section{УДОСКОНАЛЕННЯ УПРАВЛІННЯ ПЕРСОНАЛОМ У ОРГАНАХ МІСЦЕВОГО САМОВРЯДУВАННЯ}

\section{Семеняка Тетяна Володимирівна}

асистент

Криворізький національний університет

УКРÄ̈HA

На теперішній час діяльність кадрових служб органів місцевого самоврядування не в повній мірі відповідає сучасним вимогам. Це зумовлено тим, що кадрові служби не мають достатніх повноважень, відповідальності, нормативно-правового та методичного забезпечення своєї діяльності, можливостей впливати на ситуацію у кадровій сфері в органі влади, відчувають брак спеціалістів з кадрової роботи, які пройшли необхідну підготовку та мають відповідний досвід роботи. Зазначене відображається на якості роботи кадрових служб, наслідком чого $€$ непоодинокі порушення правил проведення конкурсу на заміщення вакантних посад, атестації, порядку проходження служби в органах місцевого самоврядування, накладання дисциплінарних стягнень тощо.

На сьогодні, майже усі кадрові служби органів місцевого самоврядування стикаються з однаковими проблемами при здійсненні кадрового забезпечення виконкомів міських рад, зокрема це: плинність кадрів, «старіння» кадрів, відсутність реального матеріального стимулювання і системи кадрового росту, що не дозволяють створювати ефективно діючий кадровий резерв і готувати компетентних фахівців, відсутність відповідної підготовки та досвіду тощо.

Як уже зазначалось, однією із проблем в управлінні персоналом органів місцевого самоврядування $є$ плинність кадрів. Однією із головних причин цього факту $є$ недостатнє матеріальне стимулювання посадових осіб, але існують і інші причини, зокрема напружений клімат в колективі або авторитарний стиль управління керівника відділу. Тому вважаємо, що кадровій службі необхідно надати повноважень вимагати пояснень у письмовій формі від керівників відділів і управлінь, де велика плинність кадрів та повідомляти вище керівництво про існуючу проблему.

Загалом, при здійсненні роботи з кадрами кадровим службам органів місцевого самоврядування пропонуємо керуватися наступним:

- професіоналізм та морально-етичні якості вважати єдиними критеріями відбору посадовців;

- підбирати кадри до конкретних сфер або галузей, спираючись на колегіальну думку осіб, які працюють у них;

- до складу конкурсної комісії включати психолога, який оцінюватиме саме морально-етичні і психологічні якості посадової особи;

- заздалегідь формувати кадровий резерв на відповідні посади, користуючись у тому числі послугами кадрових та рекрутингових агентств;

- запрошувати для участі у конкурсі на зайняття посад випускників вищих навчальних закладів за спеціальністю «Публічне управління та адміністрування» або «Державне управління»; 
- розробляти та впроваджувати спеціальні професійні програми адаптації та навчання для осіб, які раніше не перебували на службі в органах місцевого самоврядування.

Таким чином, з метою підвищення ефективності управління персоналом в органах місцевого самоврядування необхідно: упровадження ефрективних технологій і сучасних методів управління персоналом, спрямованих на підвищення професійної компетентності, мотивації посадовців; комплексний підхід до планування роботи з кадрами з урахуванням діяльності відповідного органу місцевого самоврядування.

\section{ЦИФРИЗАЦІЯ ВІДНОСИН ВЛАДИ, БІЗНЕСУ ТА ОСВІТИ В УКРАÏHI}

\section{НАУКОВО-ДОСЛІДНА ГРУПА:}

Адамовська Вікторія Сергіївна канд. екон. наук, доцент, в.о. завідувача кафедри обліку, оподаткування, публічного управління та адміністрування

Криворізький національний університет

Архипенко Світлана Вікторівна

канд. екон. наук., доцент, доцент кафедри обліку, оподаткування, публічного управління та адміністрування

Криворізький національний університет

Голобородько Тетяна Василівна

канд. екон. наук, старший викладач кафредри обліку, оподаткування, публічного управління та адміністрування

Криворізький національний університет

Ярова Алла Борисівна

канд. екон. наук, доцент, доцент кафедри обліку, оподаткування, публічного управління та адміністрування Криворізький національний університет

Родіонов Володимир Дмитрович здобувач вищої освіти за спеціальністю "Публічне управління та адміністрування" Криворізький національний університет

Манелюк Денис Анатолійович здобувач вищої освіти за спеціальністю "Публічне управління та адміністрування" Криворізький національний університет

УKPÄ̈HA

Сучасні виклики ставлять перед Україною нові вимоги щодо швидкості взаємодії органів влади з громадянами та між собою, швидкості реакцій на 
нововведення та зміни через розвиток техніки і технологій, готовності пристосуватись, адаптуватись до цих нововведень тощо.

Своєчасним кроком на виклики сьогодення в Україні стало створення 2 вересня 2019 року Міністерства цифрової трансформації як центрального органу виконавчої влади, що відповідає за фрормування та реалізацію державної політики у сфері цифровізації, відкритих даних, національних електронних інформаційних ресурсів та інтероперабельності, впровадження електронних довірчих послуг та ін. Також до сфери впливу нового Міністерства увійшли питання щодо розвитку цифрових навичок громадян, широкосмугового доступу до інтернету, телекомунікаційних мереж та ITіндустрії в цілому.

Нове Міністерство відкрите до пропозицій та проектів і знаходиться в постійному пошуку шляхів вдосконалення цифрового життя українців.

Тож науково-дослідною групою у складі викладачів та студентів кафедри обліку, оподаткування, публічного управління та адміністрування Криворізького національного університету розроблений ряд заходів задля реформування системи надання адміністративних, інших публічних та електронних послуг населенню. Зокрема, для удосконалення функціонування публічної служби у сфері надання електронних послуг пропонується:

1. Створення віртуального HUB'у «Влада-громадськість» у хмарному середовищі $з$ базою практичних ситуацій щодо функціонування та розвитку публічної служби з можливістю зворотного зв'язку зі сторони громадськості щодо їх вирішення.

2. Для визначення та підвищення рівня професійної компетентності державного службовця, а також для інформування громадськості з пріоритетів державної політики у відповідній сфері, удосконалити методику оцінювання ефективності роботи державного службовця за показниками KPI шляхом встановлення кожному державному службовцю завдання: наявності фахових наукових публікацій на період, що підлягає оцінюванню, в сфері публічного управління; з подальшим створенням на базі цих матеріалів публікацій віртуальної бібліотеками для підвищення професійних компетенцій (soft\&hardskills) державних службовців.

3. Для інформаційної синергії влади, бізнесу та освіти створити комплексну програму їх взаємодії у віртуальному (вебінари, онлайн та офрайн трансляції лекцій, курсів, тренінгів тощо з використанням віртуальної та доповненої реальності) та реальному середовищі (круглі столи, форуми, тематичні зустрічі, тренінги, дебати, спільна науково-дослідна робота тощо).

4. Нові тенденції е-урядування в публічному управлінні та особливості підготовки майбутніх фахівців з публічного управління та адміністрування. Наприклад:

- створення послуги з єдиного автоматизованого процесу відновлення втрачених документів (паспорт громадянина України, студентський квиток, посвідчення водія тощо);

- створення центру надання консультацій та оформлення віз, що активізує та полегшить процес організації студентського закордонного стажування; 
- створення електронних кабінетів громадян за принципом організаційної єдності усіх бюрократичних процедур (з можливістю отримання консультацій, довідок тощо);

- створення електронного реєстру виборців для формування повних та достовірних списків;

- створення додатку для громадян 3 питань створення бізнесу, оподаткування, можливостей отримання пільг за статусом особи (студент, одинока матір, сирота тощо), можливостей участі в програмах міста та закордонних програмах, можливостей працевлаштування тощо.

Вказані заходи дадуть змогу спростити процес обміну інформацією між владними структурами, закладами освіти та бізнесом, щоб на виході мати висококваліфікованого спеціаліста в галузі публічного управління та адміністрування, який отримав у закладі вищої освіти якісні знання, засновані на практичному досвіді ефективних державних управлінців та менеджерів різних рівнів управління з бізнесу з глибокими знаннями е-урядування.

Таким чином впровадження запропонованих заходів дасть змогу в Україні готувати спеціалістів з публічного управління, які готові до викликів майбутнього, які сьогодні повсякчас пов'язані з використанням досягнень техніки та технологій. 


\section{SECTION III. SCIENCES TECHNIQUES ET TI}

DOI 10.36074/29.11.2019.v2.05

ABOUT MIXING A LIQUID METAL OF A WELDING POOL
IN ARC SURFACING WITH A TRANSVERSE MAGNETIC
FIELD EFFECT

Marina Ahieieva

$\mathrm{PhD}$, Associate Professor, Department of Equipment and

Technologies for Welding Production

Donbass State Engineering Academy

Aleksandr Razmyshlyaev

Doctor of Technical Sciences, Professor, Department of Automation and Mechanization of Welding Production

State Higher Educational Institution «Priazovskiy State Technical University»

UKRAINE

The use of an external transverse magnetic field (TMF) at submerged arc surfacing and welding allows to increase the wire melting productivity and to control the depth and area of the penetration zone of the base metal. The TMF use at arc surfacing and welding also allows to mix the molten liquid metal of the weld pool and to grind the structure of the weld or surfaced bead [1]. As the grinding of structural components in the surfaced bead is due to the movement of the flows of liquid metal in the weld pool under the action of TMF, it is necessary to determine the value of the speed of this movement. There are no works in the literature to determine the parameters of alternating TMF, providing movement and mixing of the molten liquid metal in the bath during submerged arc surfacing.

A calculation method is proposed for determining the interrelation between induction and the frequency of alternating TMF, which ensure effective mixing of liquid metal along the entire length of the pool at submerged arc surfacing (welding).

Due to the fact that determining the velocity of liquid metal flows in a pool using the Navier-Stokes equations is a difficult task [2,3], the Euler equation for laminar flow was used. Considering the coordinates that characterize the process of arc surfacing (welding) with the TMF action and the fact that the Lorentz bulk forces arising in the melt are balanced by the gradient of the hydrodynamic pressure field, an equation is obtained for determining the velocity of metal flows in the pool.

For an alternating TMF in the form of rectangular impulses, taking the minimum value of the pause duration $t_{p}=0.01 \mathrm{~s}$, we obtained an approximate value of the TMF frequency $f$ at a given level of TMF induction in the head of the pool:

$$
f=\frac{1}{2 t_{i}+2 t_{p}} \approx \frac{1}{2 t_{i}}
$$

where:

$f$ - TMF frequency; 
$t_{i}$ - impulse duration, $s$;

$t_{p}$ - pause duration, $s$.

In the process of arc surfacing (welding) in TMF, the movement of liquid metal is excited and it decelerates as it moves into the tail of the weld pool. It is accepted that the average flow velocity is equal to half the flow velocity in the head of the pool.

All the necessary parameters for further calculations were determined for submerged arc surfacing by a wire with a diameter of $5 \mathrm{~mm}$ on plates with a thickness of $20 \mathrm{~mm}$ from mild steel: the geometric dimensions of the weld pool, the thickness of the liquid layer of metal under the arc, the depth of the crater of the weld pool, the height of the gain and the area of the surfaced metal. The performed flow velocity calculations showed that the average flow velocity increases with increasing surfacing current and TMF induction. Impulses duration and TMF frequency were calculated. It was stated that with increasing surfacing current, the values of the frequency of the alternating TMF at a given level of TMF induction decrease. The values of the TMF frequency, which necessary for mixing the liquid metal, increase with increasing TMF induction. It was stated that a TMF frequency of the order of $1 \ldots 1.5 \mathrm{~Hz}$ is required at an induction level of $25 \mathrm{mT}$ for complete mixing of the liquid metal (along the entire length of the tail part of the pool). The calculations showed that if the TMF induction is increased to $100 \mathrm{mT}$, the optimal frequency values are $2 \ldots 3 \mathrm{~Hz}$.

Conclusions. Thus, the calculation method allows to determine the flow velocity in the pool at submerged arc surfacing and welding with the effect of alternating TMF. The values of the induction and frequency of the alternating TMF are determined, which ensure the mixing of liquid metal along the entire length of the pool at submerged arc surfacing and welding.

\section{References:}

1. Razmyshlyaev A. D. Ahieieva M.V. (2018). TMF Influence on Weld Structure at the Welding of 12H18N9T. Materials Science Forum, (927), 1-5. Retrieved from https://doi:10.4028/www.scientific.net/MSF.927.1

3. Benilov M.S. (2008) Understanding and modeling plasma-electrode interaction in high-pressure arc discharges: a rewie. Journal of Physics D: Applied Physics, (41), 144001 (30 pp). Retrieved from https://doi:10.1088/0022-3727/41/14/144001.

4. Fan H.G., Kovacevic R. (2004) A unified model of transport phenomena in gas metal arc welding including electrode, arc plasma and molten pool. Journal of Physics D: Applied Physics. (37), 2531-2544. Retrieved from https://doi.org/10.1088/0022-3727/37/18/009. 


\title{
APPLICATIONS OF THE KALMAN FILTER TO NAVIGATION DATA
}

Kereyev Adilzhan

$\mathrm{PhD}$ doctoral student of the faculty of information technology L.N. Gumilyov Eurasian National University

Scientific advisor: Atanov Sabirzhan Doctor of technical Sciences, Professor of computer engineering Department L.N. Gumilyov Eurasian National University

REPUBLIC OF KAZAKHSTAN

\begin{abstract}
The paper deals with the actual problem of filtering the data collected by the operator during the observation and analysis of the movements of equipment provided by GPS-trackers. In particular, the paper considers the problems of using filtering mechanisms, during the movements of robotics as part of the production management system.

The novelty of the study is that for the first time a comparative analysis of the methods used in the process of data filtering is presented. The main methods of data filtering from non-stationary objects are analyzed, the main advantages and disadvantages are revealed. The authors chose the Kalman method as the leading method of filtering, which is suitable for filtering data in the online system, which is based not only on obtaining data in real time, but also on their processing with the correction of the received signal and sending it back. The author defines a mathematical model that becomes applicable to determine the qualitative choice of the method used.

The practical application of the study is determined by the fact that the design of forms and methods of application of methods of filtering navigation data can be used not only as a control system, but also an outsourcing service for testing in another area that require real-time processing.
\end{abstract}

\section{Introduction.}

Currently, widely used services using GPS-tracking, whose task is to track the routes of the observed objects in order to save them and further playback and analysis [1]. However, due to the error of the GPS-sensor caused by certain reasons, such as: loss of signal from the satellite, changing the geometry of the satellites, signal reflection, computational errors and rounding errors - the final result is not true [2].

There are both minor deviations (within $50 \mathrm{~m}$ ), which do not complicate the perception of visual information about the route and its analysis, and very significant (up to $0.5 \mathrm{~km}$, in the case of loss of satellite signal and the use of base stations up to several $\mathrm{km}$ ) [3]. To demonstrate the result of the above method, a route containing deviations from the actual location exceeding several hundred meters is used. In order to correct such errors, an algorithm is developed that performs the transformation of the coordinate sequence [4]. To filter out data that may arise due to imperfect algorithms, it is necessary to use calculations that gradually filter out false data and provide interpolation of the data to obtain a complete picture of the action. In this case we are talking about data continuity and smoothing. That is, we 
are also talking about how to reduce the possible loss of data when broadcasting in real time. In accordance with this, we will consider the problems.

\section{Literature review.}

The literature traditionally uses several data sets to provide the ability to filter data based on the selected method. We give an overview of the literature data that can contribute to the comparison of the methods used.

The standard method, which is often used by default, is the method of fast data flow filtering [5]. In this method, the main task is defined for the object, which has the ability to send both initial and final geopositional data. In other words, you need to know the start and end points to apply. All this should be indicated in the microcontroller, which necessarily becomes part of the object under study. The use of filtering on the final data is carried out with a floating point, which sharply increases the cost of the complex, which is required for the accumulation of such data [6]. In addition, a significant amount of data is based on the application of the original GPS data validation technique, which is not always interpreted correctly. The first step of the pre-filtering algorithm is to check the GPS-samples coming from the receiver. The undoubted advantages are that it is possible to reduce the amount of data transmitted and the implementation of the system on a separate microcontroller. But this can also be attributed to the disadvantages, as a significant amount of data can be closed from the operator and the final analysis system.

An alternative is the method of processing the flow of navigation data based on the method of diagnostic filtering. This method can be attributed to heuristic, as it collects data from almost all known satellite systems [7] and analyzes the level of accuracy of individual coordinates, which gradually leads to the inability to work on individual controllers and limits the speed of data processing [8]. The method is more applicable to objects that do not affect the area of accurate calculations and can be used as a basis for recording industrial operations.

Block-time filtering algorithm of geolocation data is based on the method of algorithmic search of Ramer-Douglas-Peker. It is also called the nearest-point iteration algorithm or its differentiation algorithm. This method is intended for the simplest forms of traffic accounting within a strictly defined area [9]. Its main advantages are simplicity of implementation, high efficiency and low computational complexity [10]. However, since the number of geolocation parameters includes not only the position in space, but also time, the use of only this algorithm entails the loss of information about the idle point of the object, as well as the speed of its movement [11]. Therefore, independent use of this algorithm is unacceptable for filtering geolocation data. However, this algorithm can be effectively used in conjunction with others, performing filtering of acceptable quality.

The most appropriate method for our tasks should be able to process and analyze data in the mode of their real receipt. That is, to be able to form a dynamic management and take adjustments directly from the center of the Board. In other words, it should be implemented mathematical apparatus. The basic conditions of this kind are observed in the Kalman method [12]. When controlling a dynamic system, first of all, it is necessary to fully know its phase state at each time. But it is not always possible to measure all the variables that need to be controlled, and in these cases the Kalman filter is the tool that allows you to recover the missing information using the available inaccurate (noisy) measurements [13]. 
During the analysis of various methods, we found that the filtering of geolocation data can be tested on the basis of modeling the overall structure of the closest to the ideal conditions of filtration based on the Kalman method. And this connection is necessary to develop a mathematical model that could be used not only with the dynamic (which is the standard for this method), but also with the condition of its geographical distribution, which is a complicating element.

\section{Materials and methods.}

The input data for the algorithm is a sequence of GPS coordinates. Each coordinate contains the following information from the sensor:

- latitude;

- longitude;

- azimuth in degrees;

- instantaneous speed of the object at a particular point in $\mathrm{m} / \mathrm{s}$;

- possible deviation of object coordinates from the true value in meters;

- time of receiving the coordinates of the sensor.

The paper used methods that are often considered as the basis for a holistic direction and improve the accuracy of processing of geolocalized data. If we consider the increase in reliability, we should first increase the ability to filter unnecessary information and improve the accuracy of the original data [15].

Data filtering is the elimination of redundant data that does not provide any useful information about the location of the moving object, as well as the selection of values that lead to data distortion and interference in determining the location.

\section{Results and discussions.}

To use the Kalman filter, it is necessary that the process under study is described as follows

$$
\begin{gathered}
S_{k}=A_{k} S_{k-1}+B_{k} U_{k-1}+W_{k} \\
Z_{k}=H_{k} S_{k}+V_{k}
\end{gathered}
$$

In the formula $1 S_{k} \in R^{n}$ - the state vector of the process, A - matrix of dimension $\mathrm{nm}$, which describes the transition of the observed process from the state $S_{\mathrm{k}-1}$ to the state $S_{k}$. Vector $U_{k} \in R^{l}$ describes the control effect on the process. Matrix B of dimension $\mathrm{nl}$ displays the vector of control actions $\mathrm{u}$ in the state change s. $W_{k} \in R^{n}$ is a random variable describing the error of the process under study, with $p(w) \sim N(0, Q)$, where $Q$ is the covariance matrix of the process errors.

Formula 2 describes the changes in the random process. $Z_{k} \in R^{m}$ - vector of the measured state of the process, the matrix $\mathrm{H}$ with dimension $\mathrm{mn}$ reflects the state of The $S_{k}$ process in the process change, $Z_{k} V_{k} \in R^{m}$ - random value characterizing measurement errors, with $p(v) \sim N(0, P)$, where $P$ - is the covariance matrix of process errors.

Since the process of motion of the object is studied, the equation of state is determined based on the equation of motion of the body $\overline{r_{k}}=\overline{r_{k-1}}+\overline{v_{k-1}} d t_{k}+\overline{a_{k-1}} \frac{d t_{k}^{2}}{2}$. 
In addition, there is no additional information about the process of movement, so it is considered that the control action $\mathrm{B}_{\mathrm{u}}$ equal to 0 .

For the state of the process taken vector $S_{k}=\left[x_{k} y_{k} v_{k}^{x} v_{k}^{y}\right]^{T}$, where $\mathrm{x}, \mathrm{y}-$ are the coordinates of the object, $v_{k}^{x} v_{k}^{y}-$ is the projection of velocity of object.

где х,y - координаты объекта, $v_{k}^{x} v_{k}^{y}$ - проекция скорости объекта. Thus, for the considered process equation 1 takes the following form:

$$
\begin{gathered}
S_{k}=A_{k} S_{k-1}+G_{k} A_{k} \\
A_{k}=\left[\begin{array}{cccc}
1 & 0 & d t_{k} & 0 \\
0 & 1 & 0 & d t_{k} \\
0 & 0 & 1 & 0 \\
0 & 0 & 0 & 1
\end{array}\right] \\
a_{k}=\left[\begin{array}{c}
a_{k}^{x} \\
a_{k}^{y}
\end{array}\right] \\
G_{k}=\left[\begin{array}{cc}
d t_{k}^{2} & d t_{k} \\
2 & \frac{d t_{k}^{2}}{2} \\
d t_{k} & 0
\end{array}\right]
\end{gathered}
$$

In this model, the acceleration of the object is considered as a random error of the process. We made the following assumptions:

1. Accelerations along different axes are independent random variables.

2. $p\left(a_{k}^{x, y}\right) \sim N\left(0, \sigma_{a}\right)$ - acceleration is normally distributed with zero expectation and some standard deviation $\sigma_{a}$, which is considered known.

These assumptions are made for the following reasons:

1. There is no reason to believe that the value of one component of the acceleration vector can be concluded about the value of other components.

2. Most of the time, the object moves evenly. Robotics objects are considered as possible sources of coordinates. Non-zero acceleration is usually associated either with a change of direction of movement, which occurs in a short period of time 
(from 5 to 15 seconds), or with a stop or start of movement, and acceleration or braking to the required speed also occur relatively quickly (within 10-15 seconds). Acceleration that occurs in other situations (such as overtaking or slowing down to assess the environment) also differs from zero for short periods of time.

Thus, in the formula (3) member $G_{k} A_{k}$ plays the role of a member $W_{k}$ of the formula (1).

For further calculations it is necessary to obtain the value of the matrix $\mathrm{Q}$.

$$
Q_{k}=\operatorname{cov}\left(W_{k}\right)=E\left(W_{k} W_{k}^{t}\right)-E\left(W_{k}\right) E\left(W_{k}^{t}\right)=E\left(G_{k} A_{k} A_{k}^{t} G_{k}^{t}\right)=G_{k} E\left(A_{k} A_{k}^{t}\right) G_{k}^{t}
$$

Since the components of the vector $A k$ are independent random variables,

$$
E\left(A_{k} A_{k}^{t}\right)=\left[\begin{array}{cc}
\sigma_{a}^{2} & 0 \\
0 & \sigma_{a}^{2}
\end{array}\right]
$$

Accordingly, the formula (5) has the following form

$$
Q_{k}=G_{k} G_{k}^{t} \sigma_{a}^{2}
$$

The measurement vector $Z_{k}$ for this problem is represented as follows:

$$
Z_{k}=\left[\begin{array}{c}
x_{k} \\
y_{k} \\
\vartheta_{k}^{x} \\
\vartheta_{k}^{y}
\end{array}\right]
$$

where, $x_{k}, y_{k}$-coordinates of the object received from the sensor, $\vartheta_{k}^{x}, \vartheta_{k}^{y}-$ speed of the object received from the sensor. The matrix $\mathrm{H}$ in the formula (2) is taken to be equal to the unit matrix of dimension $4 \times 4$, since in the framework of this problem it is considered that the measurement is a linear combination of the state vector and some random errors. The covariance matrix of measurement error $R$ is considered to be given. One of the possible variants of its calculation is the use of data on the expected measurement accuracy obtained from the sensor.

\section{Conclusion.}

As a result of the review of modern methods of filtering of geolocation data, it is possible to conclude that filtering is advisable to carry out first on the data source, and then on the consumer of information. Pre-filtering allows you to get rid of redundant and erroneous data, thereby reducing the load on the data channel. The final filtration must be performed on high-performance systems in order to obtain the most efficient filtration.

\section{References:}

1. Merkel, Benjamin. (2016). A Probabilistic Algorithm to Process Geolocation Data. Movement Ecology, 4(1): 26. https://doi.org/10.1186/s40462-016-0091-8.

2. Ferreira, Marta Campos, Teresa, Galvão Dias \& João Falcão e Cunha. (2019). With Whom Transport Operators Should Partner? An Urban Mobility and Services Geolocation Data Analysis. 
In Intelligent Transport Systems, From Research and Development to the Market Uptake. Cham: Springer International Publishing, 133-43.

3. Li, Xinrong \& Nayef Alsindi. 2013. Recent Advances in Indoor Geolocation Techniques. International Journal of Wireless Information Networks 20(4): 243-45. https://doi.org/10.1007/s10776-013-0235-3.

4. Kim, Jaeyoung, Yan Cui \& Kartik B Ariyur. (2018). Using Topography to Aid Smart Phones Geolocation. Wireless Networks, 24(7):2735-48. https://doi.org/10.1007/s11276-017-1500-7.

5. Rakhimberdiev, Eldar. (2015). A Hidden Markov Model for Reconstructing Animal Paths from Solar Geolocation Loggers Using Templates for Light Intensity. Movement Ecology 3(1): 25. https://doi.org/10.1186/s40462-015-0062-5.

6. Mansfield, T.O, B V Ghita \& Ambroze M.A.( 2017). Signals of Opportunity Geolocation Methods for Urban and Indoor Environments. Annals of Telecommunications, 72(3): 145-55. https://doi.org/10.1007/s12243-016-0559-y.

7. Deng, Ruoyu. (2019). SpamTracer: Manual Fake Review Detection for O2O Commercial Platforms by Using Geolocation Features. In Information Security and Cryptology, eds. Fuchun Guo, Xinyi Huang, and Moti Yung. Cham: Springer International Publishing, 384-403.

8. Huang, B. \& K. M. Carley. (2017). On Predicting Geolocation of Tweets Using Convolutional Neural Networks. In Social, Cultural, and Behavioral Modeling, eds. Dongwon Lee, Yu-Ru Lin, Nathaniel Osgood, and Robert Thomson. Cham: Springer International Publishing, 281-91.

9. Shaffer, S. A. (2005). Comparison of Light- and SST-Based Geolocation with Satellite Telemetry in Free-Ranging Albatrosses. Marine Biology 147(4): 833-43. https://doi.org/10.1007/s00227005-1631-8.

10. Thygesen, U. H. \& Anders, N. (2009). Lessons from a Prototype Geolocation Problem. In Tagging and Tracking of Marine Animals with Electronic Devices: Springer Netherlands, 257-76. https://doi.org/10.1007/978-1-4020-9640-2_16.

11. García, F., Juan Antonio, Antonio Jurado-Navas, Mariano Fernández-Navarro \& Carlos Úbeda. (2017). A Comparative Study between Iterative Algorithms for TDOA Based Geolocation Techniques in Real UMTS Networks. Mobile Networks and Applications. https://doi.org/10.1007/s11036-017-0952-4.

12. Tang, Haina, Xiangpeng Zhao, and Yongmao Ren. (2019). A Multilayer Recognition Model for Twitter User Geolocation. Wireless Networks. https://doi.org/10.1007/s11276-018-01897-1.

13. Han, Kyung Min, and Guilherme N DeSouza. (2011). Geolocation of Multiple Targets from Airborne Video Without Terrain Data. Journal of Intelligent \& Robotic Systems 62(1): 159-83. https://doi.org/10.1007/s10846-010-9442-7. 
DOI 10.36074/29.11.2019.v2.06

\section{COLMATANT AS MATERIAL FOR PREVENTION AND LIQUIDATION ABSORPTION OF DRILLING FLUIDS}

RESEARCH GROUP:

Yuliia Diachenko

lecturer, highest category

Poltava Oil and Gas College National University "Yuri Kondratyuk Poltava Polytechnic»

Serhii Osheiko

student

Poltava Oil and Gas College National University «Yuri Kondratyuk Poltava Polytechnic»

Nazar Kalnytskyi

student

Poltava Oil and Gas College National University «Yuri Kondratyuk Poltava Polytechnic»

UKRAINE

Drilling fluids, which, depending on the composition of the reagents, solve certain technical problems, make the drilling process more efficient and safer.

Some complications may occur during drilling. The most common is the absorption of mud. In this complication, the flushing fluid, which is pumped into the well, is partially or completely absorbed by the formation. This phenomenon is characteristic of porous layers with high permeability. As they pass, the pressure of the wash liquid column exceeds the reservoir pressure. Drilling fluid absorption is a difficult complication that is time consuming and time consuming.

In the oil and gas industry, when drilling wells, a preventative measure to prevent water from seeping into the well cavity is the use of clogging fillers, which, depending on the drilling conditions of a particular well, is added to the circulating drilling fluid. This task is achieved by treating the walls of the well with a special reagent - colmatant, a material for the prevention and elimination of the mud absorption, the resulting in the pores inside the rock clogged.

The main mission of the colmatants is to keep the drilling fluid in the well by stopping crack propagation. Most filler allow for cracks not larger than $6 \mathrm{~mm}$ in size.

The size and quantity of colmatant are selected based on individual geological and technical drilling conditions: reservoir permeability, pressure, pore channel size. These substances have an impact on the quality and efficiency of the opening of productive rock layers.

Colmatants are special fillers, which are powder mixtures with optimally selected components, have a variety of shape, size, physical and chemical properties. Depending on the density of the solution, different colmatants are used: fibrous, scaly, granular, and columnar.

Colmatant is chalk, wood, paper, nut shell and many other substances. They are all used in certain mining and geological conditions, but in general, their main task is to prevent the drilling fluid from entering the reservoir. 
The main function of these fillers is the formation on the surface of the filtration well of a permeable cake, which can later be removed. Accordingly, colmatants are subdivided into acid, oil and water soluble.

Acid-soluble fillers include granular carbonates of calcium, magnesium, iron. Particles of acid-soluble materials such as asbestos, siderite, marble, limestone, chalk and the like can easily be shaped and sized to contribute to the temporary colmatation of the formation pores. In addition, the rate of dissolution of calcium carbonate in hydrochloric acid is 30 times higher than siderite. Calcium lignosulfonate is used as an acid-soluble supplement that further reduces the permeability of the filtration cakes.

However, during the hydrochloric acid treatment in the bottom zone there are volumes in which the acid does not come into contact with the solid particles of colmatant; acid treatment is not the same throughout the range of the treated wellbore by the volume and duration of contact required to complete the reaction; it may cause partial destruction of the formation matrix with the release of insoluble solids.

Therefore, water soluble fillers are considered to be better and safer colmatants, that is, solely sized solids of mineral salts that do not dissolve in the killing fluid due to the near saturation of the brine, or, otherwise, ground salts as water soluble fillers supersaturated. Such fillers are easily dissolved by formation water, which is the guarantee of complete restoration of permeability. After completion of the repair work, the removal of the filtration cake from such material is carried out by flushing the well with fresh water or washing with water contained in the production of the well. The salts for the preparation of the killing fluid and the water-soluble saltcolmatant are selected from the group of sodium chloride and potassium, calcium chloride, sodium sulfate, sodium carbonate, sodium bicarbonate, calcium bromide, potassium carbonate and mixtures thereof. Recently, sodium chloride has been used as a colmatant.

As oil-soluble fillers of colmatants use oil-soluble rubber and resin. Formed in the bottom zone, the filter cake is removed by washing the bottom with hydrocarbon solvents or oil.

It should be noted that virtually all colmatants are used in combination with polymer viscosity regulators and filtration properties of brines. At the same time, only thixotropic fluid can be used as the basis for such systems, which is a difficult problem to obtain in the absence of a clay component completely. The combination of hydroxyethyl cellulose and calcium carbonate, which forms a non-thixotropic polymer solution, is most commonly used. Polymer solutions containing xanthenes gum are related to structured systems.

The most commonly used acid-soluble colmatant. It is a natural mineral substance of calcium carbonate (often marble ground), which is subjected to repeated mechanical grinding, as it is easily dissolved by acid.

The effectiveness of the use of colmatant calcium carbonate in the role of colmatant depends on its fractional composition and the pore size of the permeable layers that open. The obtained marble cake, falling with the solution into the well cavity, naturally cements the inner cavity of the wellbore. It strengthens the inner 
walls, protecting the well and equipment from damage and breakage. The solution, enriched with colmatant, having a higher specific gravity, is better able to withstand mechanical pressure from the downhole soil layers.

Colmatants act as inhibitors of the deposition of solid sediment, resulting in the pores in the soil are sealed and the process of penetration of liquids into the cavity is stopped. In addition, the use of colmatant is necessary to weigh the working solution that fills the well to equalize the internal pressure.

The negative effects of colmatation are mudsliding, so after the completion of the work they perform decolmation of the well. For the decolmation of the well after completion of the work, a solution of hydrochloric acid is used, which completely neutralizes the action of colmatant.

The most important quality of colmatant is its ability to dissolve in hydrochloric acid. Therefore, for colmatation, no ground dolomite is used, but only microcalcite is calcium carbonate, $98 \%$ soluble in mineral acids.

Thus, the main advantages of using colmatant can be distinguished. By natural cementation, it creates a filtering protective layer on the inner surface of the wells, which prevents groundwater particles from entering the working solution with groundwater. This greatly increases the efficiency of productive collectors and protects them from unnecessary contamination.

The effect of using colmatant is maintained throughout the required time. The benefits of colmatant make it a sought after material to combat drilling fluid absorption.

Therefore, colmatation (blocking) is an integral part of a set of preventive measures to maintain the well performance at the required level and is necessary to prevent the destruction of the area immediately adjacent to the well.

The effect of using colmatant is, in most cases, positive.

\section{References:}

1. Abrams, A.. (1977). SPE 58793 Optimizing the Selection of Bridging Particles for Reservoir Drilling Fluids Mud Design to Minimize Rock Impairment Due to Particle Invasion. JPT.

2. Kaeuffer, M. (1973). Determination de L'Optimum de Remplissage Granulometrique et Quelques Proprietes S'y Rattachant. Congres de l'A.F.T.P.V., Rouen.

3. Stephen, Vickers, Martin, Cowie, Tom \& Jones, Baker. Hughes Drilling Fluids. AADE-06-DF-HO16 A New Methodology that Surpasses Current Bridging Theories to Efficiently Seal a Varied Pore Throat Distribution as Found in Natural Reservoir Formations, (16).

4. Gray, Darley. Composition and properties of drilling agents (washing liquids). (D. Stolyarov, translation from English).

5. Mihalik, P., Lundie, P., Growcock, F., Calloni, G.\& Davidson, E. SPE/IADC 52815 New Permeability Plugging Apparatus Procedure Addresses Safety and Technology Issues. Baroid Drilling Fluids. 


\section{DEVELOPMENT OF AN OPTIMAL AIRCRAFT CONTROL SYSTEM} RESEARCH GROUP:
Kutzhanova Dina Spartakkyzy
$1^{\text {st }}$ year master's degree

Eurasian national university after L.N. Gumilev

Amirzhanova Zinara Bekbolatovna

$1^{\text {st }}$ year doctoral student

Eurasian national university after L.N. Gumilev

Satybaldina Dana Karimtaevna

Associate professor, candidate of technical sciences

Eurasian national university after L.N. Gumilev

REPUBLIC OF KAZAKHSTAN

Modern airplanes and helicopters are equipped with a wide variety of equipment and automatic systems. Avionics makes up most of the cost of manufacturing an aircraft [1].

First of all, on manned aircraft normal conditions should be created for the life and work of the crew. Various on-board equipment can be used by the crew to control the aircraft, to carry out economic and scientific research work, or to monitor the technical condition of all on-board devices, systems and assemblies.

Due to the increase in flight speeds, the crew does not have time to adjust the flight mode according to instrument readings and to effectively use various on-board equipment. Therefore, the processes for controlling the flight and operation of most units are automated $[2,3,4,5]$.

The perturbed lateral motion of the aircraft relative to a steady horizontal flight can be described by a system of fifth-order equations:

$$
\left\{\begin{array}{c}
\dot{\beta}=\omega_{y}+\frac{z^{\beta}}{m_{0} V_{0}} \beta+\frac{g}{V_{0}} \gamma, \\
\dot{\omega}_{x}=\frac{J_{x y}}{J_{x}} \dot{\omega}_{y}+\frac{1}{J_{x}}\left[\frac{\partial M_{x}}{\partial \beta} \beta+\frac{\partial M_{x}}{\partial \omega_{x}} \omega_{x}+\frac{\partial M_{x}}{\partial \omega_{y}} \omega_{y}+\frac{\partial M_{x}}{\partial \delta_{\mathrm{B}}} \delta_{\mathrm{B}}\right], \\
\dot{\omega}_{y}=\frac{J_{x y}}{J_{y}} \dot{\omega}_{x}+\frac{1}{J_{y}}\left[\frac{\partial M_{y}}{\partial \beta} \beta+\frac{\partial M_{y}}{\partial \omega_{x}} \omega_{x}+\frac{\partial M_{y}}{\partial \omega_{y}} \omega_{y}+\frac{\partial M_{y}}{\partial \delta_{n}} \delta_{n}\right], \\
\dot{\gamma}=\omega_{x}, \\
\dot{\psi}=\omega_{y},
\end{array}\right.
$$

where $\beta$ - glide angle, $\psi$ - yaw angle, $\gamma$ - lurch angle, $\omega_{y}$-angular velocity of yaw, $\omega_{x}$ - angular velocity of lurch, $\delta_{\mathrm{B}}, \delta_{n}$ - deflection angles of aileron and elevator, respectively.

The aircraft is controlled by deflecting the ailerons and the elevator $\left(\delta_{\mathrm{B}}, \delta_{n}\right.$ angles). The minimized functional of the quality is defined as follows [6]:

$$
J=\lim _{\left(T-t_{0}\right) \rightarrow \infty} \frac{1}{2} \int_{t_{0}}^{T}\left[\left(\frac{\delta_{\mathrm{B}}}{\delta_{\mathrm{B}_{0}}}\right)^{2}+\left(\frac{\delta_{n}}{\delta_{n_{0}}}\right)^{2}+\left(\frac{\gamma}{\gamma_{0}}\right)^{2}+\left(\frac{\beta-\psi}{\varepsilon_{0}}\right)^{2}\right] d t .
$$

Functional $J$ is presented in the form $\int_{t_{0}}^{T}\left(x^{\prime} Q x+u^{\prime} R u\right) d t$, where 


$$
Q=\left(\begin{array}{ccccc}
1 & 0 & 0 & 0 & -2 \\
0 & 0 & 0 & 0 & 0 \\
0 & 0 & 0 & 0 & 0 \\
0 & 0 & 0 & 1 & 0 \\
0 & 0 & 0 & 0 & 1
\end{array}\right), R=\left(\begin{array}{ll}
1 & 0 \\
0 & 1
\end{array}\right), \delta_{\mathrm{B}_{0}}=\delta_{n_{0}}=\gamma_{0}=\varepsilon_{0}=1 .
$$

Assume that all elements of the state vector are accessible to measurement instrument:

$$
y=E x, \text { where } x=\left(\beta, \omega_{x}, \omega_{y}, \gamma, \psi\right) .
$$

If full information about the parameters and state of the system is known, the optimal control is described by the formula $[7,8]$ :

$$
\delta(t)=-R^{-1} B^{T}(t) S_{1}(t) x(t),
$$

where $S$ is from a Riccati type equation:

$$
\left\{\begin{array}{l}
\dot{S}_{1}(t)+S_{1}(t) A(t)+A^{T}(t) S_{1}(t)+S_{1}(t) B(t) R^{-1} B^{T}(t) S_{1}(t)+Q=0, \\
S_{1}(T)=S
\end{array}\right.
$$

Moreover, $S$ satisfies an equation of the Riccati-Lurie type:

$$
S A=A^{T} S+S B R^{-1} B^{T} S+Q=0,
$$

The results of modeling the behavior of system (1) with control (3)-(5) are presented in Figure 1 [9].

The output is the state vector $x(t)$. Figure 1 shows the transient graphs of the glide angle, angular velocity of yaw, angular velocity of lurch, lurch angle and yaw angle respectively. The period of operation of the system is selected $50 \mathrm{~s}$. As can be seen from the graphs, the controller copes with its task and, given the initial values of the object at the angles $\beta$ and $\gamma$, displays the system in its original position. To satisfy the initial conditions of the system, it is necessary to reject the components $\omega_{x}$ and $\omega_{y}$.
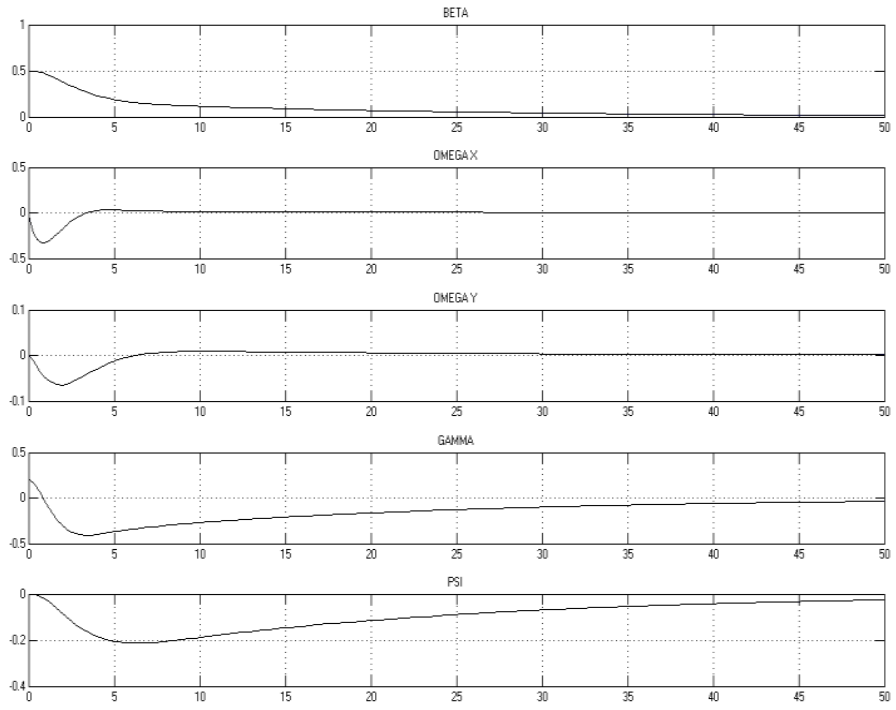

Fig. 1. Object transient graphs 


\title{
References:
}

1. Raspopov, V. Y. (2010). Mikrosistemnaya avionika. Tula. [in Russian].

2. Bodner, V. A. (1973). Sistemy upravleniya letatel'nymi apparatami. M.: Mashinostroenie. [in Russian].

3. Denisov, V. G. (1963). Navigatsionnoe oborudovanie letatel'nyh apparatov. M.: Oborongiz. [in Russian].

4. Kuzovkov, N. T. (1976). Sistemy stabilizatcii letatel'nyh apparatov. M.: Vysshaya shkola. [in Russian].

5. Pavlov, V. A., Ponyrko, E.A. \& Hovanskiy, U.M. (1964). Stabilizatsiya letatel'nyh apparatov $i$ avtopiloty. M.:Vysshaya shkola. [in Russian].

6. Braison, A. \& Ho Yu-Shi. (1972). Prikladnaya teoriya optimal'nogo upravleniya. (A.M. Letova., perevod $s$ angl., red.). M.: Mir. [in Russian].

7. Brodskiy, S. A., Nebylov, A. V. \& Panferov, A. I. (2006). Kontrol' parametrov $i$ stabilizatsii uprugih kolebaniy slozhnyh ob'ektov i konstruktsiy. Giroskopiya i navigatsiya. [in Russian].

8. Satybaldina, D. K., Shigirova, A. M. \& Daukenova, N. N. (2017). Development of an optimal control system of aerial vehicle. Vysokiye tekhnologii i modernizatsiya ekonomiki: dostizheniya, i novye vektory razvitiya: sbornik nauchnyh trudov po materialam I Mezhdunarodnyi nauchnoprakticheskoi konferentsii (279-284 p). Ekaterinburg. [in Russian].

9. Lazarev, Z. H. (2005). Modelirovanie protsessov i sistem v MATLAB. Piter. [in Russian].

\section{DEVELOPMENT OF UNMANNED AERIAL VEHICLE CONTROL SYSTEM}

\author{
RESEARCH GROUP: \\ Uashov Yerbolat Kabimollauly \\ 1st year master's degOree \\ Eurasian national university after L.N. Gumilev \\ Mashtayeva Aida Asyl'khanovna \\ 1st year doctoral student \\ Eurasian national university after L.N. Gumilev \\ Satybaldina Dana Karimtaevna \\ Associate professor, candidate of technical sciences \\ Eurasian national university after L.N. Gumilev
}

REPUBLIC OF KAZAKHSTAN

The development of reconnaissance and targeting systems based on unmanned aerial vehicles (UAVs) is currently carried out by virtually all industrialized countries of the world.

The main advantages of UAV helicopter type are maneuverability, the ability of vertical takeoff and landing, as well as the implementation of the hovering mode in the air. These advantages allow you to perform many tasks, such as monitoring, cargo delivery, fire fighting, field processing, etc. The ability of vertical takeoff helps to solve the problem with the implementation of the takeoff of the aircraft from small- 
sized take-off sites, roofs of buildings and from the ship. Hovering mode allows longterm monitoring of the object. The maneuverability of a helicopter-type UAV is convenient for solving tasks in which it is necessary to make quick decisions to achieve the goal [1].

In this article, a model of a helicopter-type UAV, the structure of the control system are developed and the parameters of the autopilot settings are calculated $[2,3,4,5]$.

The helicopter can be modeled by combining five subsystems: the main rotor, fuselage, tail (consist of horizontal stabilizer and vertical keel), tail rotor and engine. $m r$ is main rotor, $t r$ is tail rotor, $g$ is gravity, $d$ is resistance

$$
\begin{gathered}
F_{x}=X_{m r}+X_{t r}+X_{g} \\
F_{y}=Y_{m r}+Y_{t r}+Y_{g} \\
F_{z}=Z_{m r}+Z_{t r}+Z_{g} \\
L=L_{m r}+L_{t r}+L_{d} \\
M=M_{m r}+M_{t r}+M_{d} \\
N=N_{m r}+N_{t r}+N_{d}
\end{gathered}
$$

where $X, Y, Z$ are the external aerodynamic forces on the connected axes, $L, M, N$ are external aerodynamic moments through the axes.

Matrix equation of the system:

$$
\begin{gathered}
F_{x}=-T_{m r} \sin \sin \left(a_{1}\right)-\sin \sin (\theta) m g \\
F_{y}=T_{m r} \sin \sin \left(b_{1}\right)+T_{t r}+\sin \sin (\phi) \cos \cos (\theta) m g \\
F_{z}=-T_{m r} \cos \cos \left(b_{1}\right) \cos \cos \left(a_{1}\right)+\cos \cos (\phi) \cos \cos (\theta) m g \\
\tau_{x}=Y_{m r} h_{m r}-Z_{m r} y_{m r}+Y_{t r} h_{t r}+Q_{m r} \sin \sin \left(a_{1}\right) \\
\tau_{y}=-X_{m r} h_{m r}-Z_{m r} l_{m r}-Q_{m r} \sin \sin \left(b_{1}\right) \\
\tau_{z}=X_{m r} y_{m r}-Y_{m r} l_{m r}-Y_{t r} l_{t r}+Q_{m r} \cos \cos \left(a_{1}\right) \cos \cos \left(b_{1}\right)
\end{gathered}
$$

Now let's move from the nonlinear view to the linear one [6].

For steady-state flight systems, the equations of spatial motion can be linearized by usual methods. With the help of Taylor series expansion, the external forces acting on the platform will become linear functions of perturbed states, according to the method of small perturbations $x=x_{e}+\Delta x$ and write the equations as

$$
\begin{gathered}
F_{x}=X=X_{e}+\frac{d x}{d u} \Delta u+\frac{d x}{d w} \Delta w+\frac{d x}{d q} \Delta q+\frac{d x}{d \theta} \Delta \theta+\frac{d x}{d v} \Delta v+\frac{d x}{d p} \Delta p+\frac{d x}{d \phi} \Delta \phi+\frac{d x}{d r} \Delta r \\
+\frac{d x}{d \theta_{0 m r}} \Delta \theta_{0 m r}+\frac{d x}{d a_{1}} \Delta a_{1}+\frac{d x}{d b_{1}} \Delta b_{1}+\frac{d x}{d \theta_{0 t r}} \Delta \theta_{0 t r}
\end{gathered}
$$

where $u, w, v$ are the projections of the helicopter velocity vector on the connected axes, $p, q, r$ are the projections of the angular velocity vector on the connected axes, $\phi, \theta, \psi$ are the Euler angles of roll, pitch and yaw, respectively.

Now let's simplify

$$
\begin{gathered}
X=X_{e}+X_{u} \Delta u+X_{w} \Delta w+X_{q} \Delta q+X_{\theta} \Delta \theta+X_{v} \Delta v+X_{p} \Delta p+X_{\phi} \Delta \phi+X_{r} \Delta r \\
+X_{\theta_{0 m r}} \Delta \theta_{0 m r}+X_{a_{1}} \Delta a_{1}+X_{b_{1}} \Delta b_{1}+X_{\theta_{0 t r}} \Delta \theta_{0 t r}
\end{gathered}
$$

Let's represent the system in vector form

$$
\dot{x}=A x+B u
$$

where $x=(u w q v p \phi)$ is the state vector; $U=\left(\theta_{0 m r} a_{1} b_{1} \theta_{0 t r}\right)$ is the control vector, the elements of the matrix $A$ are the linearization coefficients of the original nonlinear system. 
In our case, the standard autopilot model was taken on four control channels: pitch, roll, yaw, speed. The control system consists of two feedback loops. The internal loop (static feedback output) provides stability and increasing of decoupling. The external loop (PI regulators) provides the required productivity of the tracking installation.

The controller is set using the setting commands in Simulink [7].

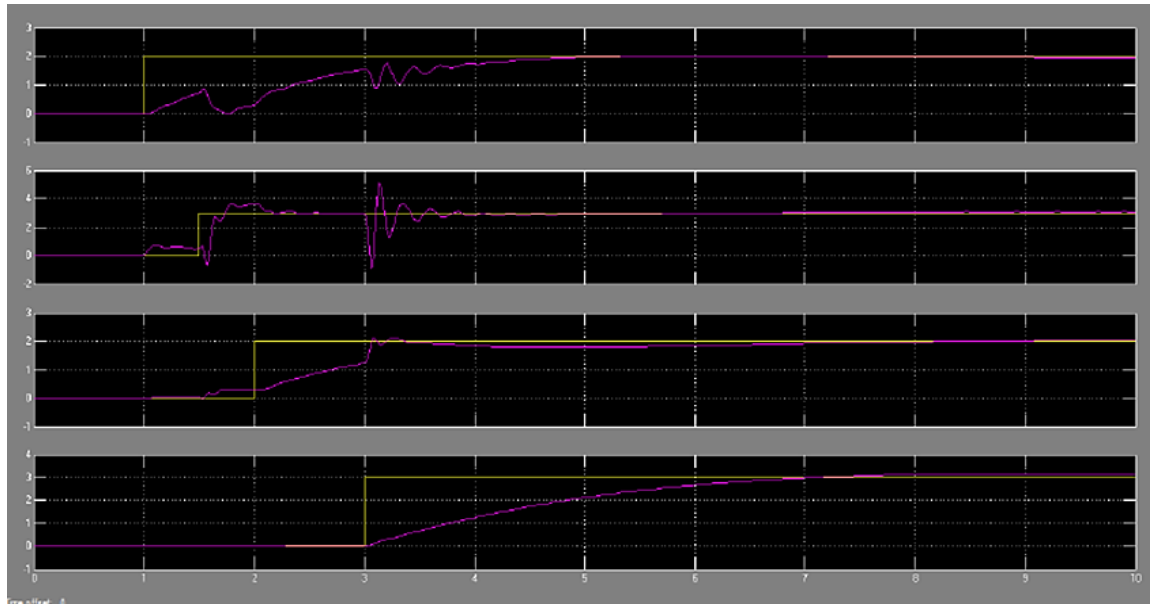

Fig. 1. Transients

\section{References:}

1. Bogoslovskiy, S. V. \& Dorofeev, A. D. (2002). Dynamica poletov letatel'nykh apparatov. SPb: GUAP. [in Russian].

2. Krasil'shchikova, M. N. \& Sebryakova, G. G. (2003). Upravlenie i navedenie bespilotnykh manevrennykh letatel'nykh apparatov na osnove sovremennykh informatsionnykh tekhnologiy. M.: FIZMATLIT. [in Russian].

3. Anderson, John D. (2008). Vvedenie v polety (shestoe izdanie). McGrawHill. ISBN 0-07-1263187. [in Russian].

4. Andrievskiy, B. R. \& Fradkov, A. L. (2004). Sovremennye napravleniya sinteza sistem avtomaticheskogo upravleniya letatel'nymi apparatami. Sankt-Peterburg: Institut problem mashinoveden'ya RAN. [in Russian].

5. Bodner, B. A. (1973). Sistemy upravleniya letatel'nymi apparatami. M.: Mashinostroenie. [in Russian].

6. Miroshnik, I. V. (2005). Teoriya avtomaticheskogo upravleniya. Lineynye sistemy. SPb. [in Russian].

7. Lazarev, Z. H. (2005). Modelirovanie protsessov i sistem v MATLAB. Piter. [in Russian]. 
DOI 10.36074/29.11.2019.v2.07

\title{
EFFICIENCY OF APPLICATION OF DRILLING FLUIDS WITH HIGH LUBRICATING PROPERTIES FOR DRILLING DIRECTIONAL AND HORIZONTAL WELLS
}

\begin{abstract}
Victoriia Dmytrenko
PhD in Technical science, Doctor of Philosophy, Associate Professor National University "Yuri Kondratyuk Poltava Polytechnic»

Yuliia Diachenko

highest category lecturer

Poltava Oil and Gas College National University "Yuri Kondratyuk Poltava Polytechnic»
\end{abstract}

UKRAINE

Drilling of directional and horizontal wells covers an extremely wide range of issues, which are almost impossible to solve given the specificities of each geological region.

Many works of domestic and foreign scientists are devoted to the study of problems at drilling wells of and their solution, in particular, M. Aliyeva, V. Askerov, H. Ahaeva, D. Baldenka, R. Bitto, N. Bezukhova, A. Bulatova, I. Vaska, V. Hlushich, A. Hryhoryan, R. Ioanesian, A. Kalinina, H. Carrison, K. Krause, V. Krylov, Y. Kuntsyak, A. Kozlova, Y. Kotskulich, G. Lehnitsky, O. Messer, M. Myslyuk, V. Mori, O. Ohanova, H. Ohanova, A. Povalikhina, E. Sakovicha, M. Sevela, Sh. Takhutdinova, D. Furmentro, B. Chernova, V. Yasova etc. On the basis of scientific researches they have developed the latest technologies and technical means for efficient construction of directional and horizontal wells [1].

In Ukraine, the drilling of horizontal wells was started in 1957 at the Boryslavsky field at well depths of $2800-2900 \mathrm{~m}$. However, discharge was of the nature of an industrial experiment and was terminated as too high-cost, not prepared in terms of technical and human resources and in the absence of sophisticated technologies [2].

At the same time, the leading oil and gas producing countries of the world - the USA, Canada, France, Russia, China in 1980 - 1990 reached high rates of horizontal drilling. Thus, in the USA during the fifteen-year period (1988 - 1992), 4529 horizontal wells were drilled, in Canada over 5000 horizontal wells and side horizontal barrels were drilled during this period, in Russia in the first half of the 90s more than 230 horizontal wells were drilled $[3,4]$.

The experience of leading Western European and American companies shows that the most favorable mining and geological conditions for the drilling of directional and horizontal wells are hydrocarbon deposits, which are confined to massive and powerful thicknesses of limestone, dolomite, sand [3,4] . For the Ukrainian oil and gas regions - the Dnieper-Donetsk Basin (DDB) - geological conditions are much more complicated [2].

A large number of oil and gas fields in Ukraine are in the late final stages of development, the increase of which is possible with the incision of the side trunks in the operational wells of the inactive fund. Thanks to this technology, the so-called 
"stagnant zones of the reservoir", as well as heavy oil and gas reserves, which were previously impossible to extract, are involved in the development. Therefore, issues related to the recovery of such deposits are relevant.

Horizontal well drilling is one of the effective methods of forming an optimal system for the development of oil and gas fields, increasing the oil and gas extraction rate from reservoirs, as well as restoring the productivity of wells at latestage fields. The opening of the productive layer with a horizontal barrel increases the productivity of the well due to the increase in the filtration area, the degree of extraction of hydrocarbons, eliminates the possibility of water flow during the operation of the well, which is important for low-permeability horizons, as well as for reservoirs with vertical fracture [5].

The urgency of this problem increases with enhancing horizontal drilling volumes and amplifying in the depth of drilling.

For qualitative drilling of horizontal wells, additional lateral shafts, where there are potentially high energy costs for overcoming axial and axial friction between the pipe column and the well wall, a prerequisite is the use of drilling fluids with high lubricating properties [6,7].

In modern drilling conditions, characterized by the diversity of geological structure of the fields, the intense growth of depths of wells, high temperatures, high environmental requirements for materials, complex structures of wells, and the layout of the bottom of drilling columns are great importance is attached to the development and application of drilling fluids with improved lubrication (tribotechnical) properties. Tribotechnical properties determine the ability of drilling fluids to reduce the friction force between the contacting surfaces.

One of the most important areas of technology improvement is the use of highly effective synergies with the components of the mud solution lubricants with a given multifunctional effect.

Currently, the market of products and services has a fairly large selection and range of lubricants, technologies for their application and methods of quality control of friction properties of drilling fluids. The proposed compositions of lubricant additives are characterized by multifunctional of action, so when they are selected, taking into account the effectiveness in specific geological and technical conditions, it is necessary to distinguish special requirements for their quality.

Increasing the lubricant capacity of the drilling fluid not only improves the antitheft properties, but also favorably affects all components of the technological process of deepening of the well: increases the wear resistance and durability of the friction units of the drilling equipment, downhole motors and leveling, lowering; prevents additional wetting of clay rocks by hydrophobization and reducing the permeability of the filter crust etc.

When conducting directional and horizontal wells, the high pressure value of the drill string on the walls of the well. This causes considerable resistance to movement of the drill string, increased torque and energy consumption. The magnitude of these efforts is determined by the type of rock, the surface roughness of the column and the type of drilling mud. The friction forces can be minimized by removing the sludge, reducing the thickness of the clay crust, eliminating sharp variations in curvature, but more efficiently by improving the lubricating properties of the mud. 
Compositions of lubricant additives, along with increasing the durability and wear resistance of the friction units of drilling equipment and rock-destroying tools, environmental cleanliness, must function effectively in complex mining and geological conditions characterized by, for example, poly-mineral and hydrogen sulfide aggression, high temperatures and high temperatures, hydrophobic, anticorrosive and other beneficial properties.

Thus, the development and widespread introduction of effective and environmentally friendly lubricants that have useful multifunctional properties in various drilling mud systems is one of the topical areas for improving drilling technology. Of particular importance is the maintenance of a certain level of lubricating properties of the drilling mud during the construction of directional and horizontal wells of great length.

Therefore, today lubricants are important drilling reagents. Drilling fluids that successfully perform their function when drilling ordinary directional wells are the basis that needs modification to drill a horizontal section.

\section{References:}

1. Kuntsyak, R. (2011). Improvement of drilling technology of directional and horizontal wells in unstable rocks (on the example of deposits of the Dnieper-Donetsk basin). Ivano-Frankivsk.

2. Kuntyak, Ya. (2011). Experimental and industrial researches and prediction of stability of horizontal wells in unstable rocks. Exploration and development of oil and gas fields.

3. Mensa-Wilmot, G., Krepp, T. \& Stephen, I. Dual Torque Concept Enhances PDS Bit Efficiency in Directional and Horisontal Drilling Programs. Paper SPE/IADC 52879 presented at the SPE/IADC Drilling Conference. 9 - 11 March, 1999, Dallas. Texas. Amsterdam. Netherlands.

4. Shults P.K. \& Gobb C. (1992). Fiber optic improve down hole video. Oil and gas Journal, (5), $46-51$.

5. Lazarenko, O., Livinskii, A. (2014). The Experience of Drilling Horizontal Wells in the Gnidintsev Field. Rock-destroying and metal-working tools - technique and technology of its production and application. K .: ISM, NAS of Ukraine, (17), $47-52$.

6. Gavrylenko, N., Davydenko, A. \& Doodle, N. (1990). Surface-active antifriction additives during well drilling. Kiev: Scientific Thought.

7. Scientific Bulletin IFNTUNG. (1975). Drilling fluids with improved lubricating properties. Oil and gas engineering. $\mathrm{M}$.: Nedra. 
DOI 10.36074/29.11.2019.v2.08

FEATURES OF STRESS-STRAIN STATE MODELING OF PIPELINES WITH GAS-LIQUID CHEMICALLY ACTIVE MIXTURES

RESEARCH GROUP:

Andrij Oliinyk

Doctor of Technical Sciences, profesor in the Department of Applied Mathematics Ivano-Frankivsk National Technical University of Oil and Gas

Boris Nezamay

Candidate of Technical Sciences, lecturer in the Department of Applied Mathematics Ivano-Frankivsk National Technical University of Oil and Gas

Artur Shalamai

Student of the Institute of information Technology Ivano-Frankivsk National Technical University of Oil and Gas

UKRAINE

Defining the parameters of the stress-strain state of the objects of the known information about the changes in their spatial configuration - usually such information are data on the surface of the moving points of the body, based on which one can construct a mathematical representation [1] the position vector of any point of the body to control at times. For an object having a cylindrical shape (pipes for various purposes, wells with gas-liquid flow, etc.), the presentation can be written as:

$$
\begin{aligned}
& \overrightarrow{\mathrm{r}}(\mathrm{s}, \varphi, \mathrm{r}, \mathrm{t})=\vec{r}_{l}(\mathrm{~s}, \varphi, \mathrm{r}, \mathrm{t})+\rho(\mathrm{s}, \varphi, \mathrm{r}, \mathrm{t}) \cdot \\
& \left(\cos \omega(\mathrm{s}, \varphi, \mathrm{r}, \mathrm{t}) \overrightarrow{\mathrm{b}}_{1}+\sin \omega(s, \varphi, \mathrm{r}, \mathrm{t}) \overrightarrow{\mathrm{n}}_{1}\right)+, \\
& +\psi(\mathrm{s}, \varphi, \mathrm{r}, \mathrm{t}) \vec{\tau}_{1}-\frac{\mathrm{D}}{2} \vec{n}_{l}
\end{aligned}
$$

where: $s, \varphi, r, t$ - associated with the curved cylindrical body coordinates respectively along the axis of the body $0<S<L, 0 \leq \varphi \leq 2 \pi$ and the radius of the object $R_{\text {leak }<r<=} R_{\text {zovn }}, L$ - the length the investigated object; $\vec{r}_{l}$ - radius vector of a point on the generating facility; $D$ - its diameter; $\rho(s, \varphi, r, t) ; \omega(s, \varphi, r, t)$; $\psi(s, \varphi, r, t)$ - features that characterize the studied body movement points respectively in the radial, polar and longitudinal directions, $\overrightarrow{\tau_{l}}, \overrightarrow{b_{l}}, \overrightarrow{n_{l}}$ - tangent vectors, binormal and normal to the generatrix object. Setting functions 
$\rho(s, \varphi, r, t)$; and $\psi(s, \varphi, r, t)$ based on the movement of points on the control surface allows time to make calculations strain tensor components $\varepsilon_{j}^{i}$.

$$
\varepsilon_{i j}\left(s, \varphi, r, t_{k}\right)=\frac{1}{2}\left(g_{i j}\left(s, \varphi, r, t_{k}\right)-g_{i j}\left(s, \varphi, r, t_{0}\right)\right),
$$

where $g_{i j}$ - the components of the metrical tensor matrix, when the elastic deformation considered, recalculation of these components produced by Hooke's law.

For isotropic body (using (2)):

$$
\sigma_{i j}=\lambda I_{1}(\varepsilon) g_{i j}\left(s, \varphi, r, t_{0}\right)+2 \mu \varepsilon_{i j}(s, \varphi, r, t),
$$

where $I_{1}(\varepsilon)=\sum_{i=1}^{3} \sum_{j=1}^{3} \varepsilon_{i j}(s, \varphi, r, t) g_{i j}\left(s, \varphi, r, t_{0}\right)$ - the first strain invariant strain tensor; $\lambda, \mu$-Lame parameters material , related to the Young's modulus $E$ and Poisson's ratio $\sigma$ of the material relations:

$$
\mu=\frac{E}{2(\sigma+1)} ; \lambda=\frac{E \sigma}{(1+\sigma)(1-2 \sigma)} ;
$$

For the anisotropic model using relations (3) and (4) shall be replaced by the formula:

$$
\sigma_{i j}(s, \varphi, r, t)=\sum_{k, l=1}^{3} C_{i j k l} \varepsilon_{k l}(s, \varphi, r, t),
$$

where $C_{i j k l}$ - elastic modules tensor components of the material.

The method presented and substantiated in detail in [1], its peculiarity is that the finding of stress - strain state of the object is on the basis of certain integrated indicators - displacements of the body surface without detailing the causes of these movements. Based on the change of the stress - strain state of the object it manages to track down potentially dangerous areas where tensions are taking the critical level, or change the stress is such that can cause depressurization of the object as well, and potentially dangerous environmental effects.

For the estimation of annular stresses, systems of differential equations of equilibrium are used for toroid and quasi-rectilinear sections, taking into account the reduction of wall thickness due to the transport of gas-liquid mixtures with aggressive components. For a quasi-straight section, a system for determining the components of a displacement vector takes the form (6). Taking into account that the shape of the deformed cross-section differs little from the shape of the circle, due to the averaging of the solutions of systems (6) and (7), formulas were obtained for the approximate estimation of the ring stresses (9). 


$$
\left\{\begin{array}{l}
(\lambda+2 \mu)\left(\frac{\partial^{2} \omega}{\partial r^{2}}+\frac{1}{r} \frac{\partial \omega}{\partial r}-\frac{\omega}{r^{2}}\right)-\lambda\left[\frac{\partial v}{\partial \theta} \frac{2}{r^{3}}-\frac{1}{r} \frac{\partial^{2} v}{\partial r^{2}}\right]+ \\
+\mu\left[\frac{\partial^{2} v}{\partial r \partial \theta} \frac{1}{r^{2}}+2 \frac{\partial^{2} \omega}{\partial \theta^{2}} \frac{1}{r^{2}}-\frac{4}{r^{3}} \frac{\partial \omega}{\partial \theta}-2 \frac{\partial v}{\partial \theta} \frac{1}{r^{4}}\right]=0 \\
-4 \mu\left[\frac{1}{2}\left(\frac{\partial v}{\partial r}+\frac{\partial \omega}{\partial \theta}-2 \frac{v}{r}\right) \frac{1}{r^{3}}\right]+\frac{2 \mu}{r^{2}}\left[\frac{1}{2}\left(\frac{\partial^{2} v}{\partial r^{2}}+\frac{\partial^{2} \omega}{\partial \theta^{2}}-2 \frac{\partial v}{\partial r} \frac{1}{r}-\frac{2 v}{r^{2}}\right)\right]+ \\
+2 \mu\left(\frac{1}{2} \frac{\partial^{2} v}{\partial r \partial \theta}+\frac{\partial^{2} \omega}{\partial r \partial \theta}-\frac{2}{r} \frac{\partial v}{\partial r}\right) \frac{1}{r^{2}}+\frac{3 \mu}{r^{3}}\left(\frac{\partial v}{\partial r}+\frac{\partial \omega}{\partial \theta}-\frac{2 v}{r}\right)=0
\end{array}\right.
$$

for the toroidal area, a similar system is written as:

$$
\left\{\begin{array}{l}
(\lambda+2 \mu)\left[\frac{\partial^{2} u}{\partial r^{2}}+\frac{\partial u}{\partial r} \frac{1}{r}-\frac{u}{r^{2}}\right]+\frac{\partial^{2} u}{\partial \theta^{2}} \mu \frac{1}{r^{2}}+\frac{\partial^{2} v}{\partial r \partial \theta}\left(\lambda \frac{1}{r^{2}}+\mu \frac{1}{r^{2}}\right)+(\lambda+2 \mu) \frac{\partial u}{\partial r} \frac{\cos \theta}{(R-r \cos \theta}+ \\
+\mu \frac{\partial u}{\partial \theta} \frac{\sin \theta}{r(R-r \cos \theta)}+\frac{\partial v}{\partial r}(\lambda+2 \mu) \frac{\sin \theta}{r(R-r \cos \theta)}-2 \frac{\partial v}{\partial \theta}(\lambda+2 \mu) \cdot \frac{1}{r^{3}}+ \\
+u\left(-\frac{1}{r^{2}}(\lambda+2 \mu)-(\lambda+2 \mu) \frac{\cos ^{2} \theta}{(R-r \cos \theta)^{2}}\right)+v\left[(\lambda+2 \mu) \frac{\sin \theta \cos \theta}{r(R-r \cos \theta)^{2}}-\frac{\sin \theta(\lambda+2 \mu)}{r^{2}(R+r \cos \theta)}\right]=0 \\
\frac{\partial^{2} u}{\partial r \partial \theta}(\lambda+\mu) \frac{1}{r^{2}}+\frac{\partial^{2} v}{\partial r^{2}} \mu \frac{1}{r^{2}}+(\lambda+2 \mu) \frac{\partial^{2} v}{\partial \theta^{2}} \frac{1}{r^{4}}+\frac{\partial u}{\partial \theta}\left(3 \mu \frac{1}{r^{3}}+\lambda \frac{1}{r^{3}}-\frac{(\lambda+\mu) \cos \theta}{r^{2}(R+r \cos \theta)}\right)+ \\
+\frac{\partial v}{\partial r}\left(-\mu \frac{1}{r^{3}}-\mu \frac{1}{r^{2}} \frac{\cos \theta}{R-r \cos \theta}\right)+(\lambda+2 \mu) \frac{\partial v}{\partial \theta} \frac{\sin \theta}{r^{3}(R-r \cos \theta)}+u\left((\lambda+\mu) \frac{1}{r^{2}} \frac{R \sin \theta}{(R-r \cos \theta)^{2}}\right)+ \\
+\frac{v(\lambda+2 \mu)}{r^{3}} \frac{R \cos \theta-r}{(R-r \cos \theta)^{2}}=0
\end{array}\right.
$$

with boundary conditions

$$
\begin{gathered}
\left\{\begin{array}{l}
\left.\sigma^{22}\right|_{r=R \text { int }}=P_{\mathrm{int}} ; \\
\left.\sigma^{22}\right|_{r=\operatorname{Re} x t}=P_{\text {ext }},
\end{array}\right. \\
\sigma_{r g}=\frac{R_{\mathrm{int}}^{2}(\theta) P_{\mathrm{int}}}{R_{\text {ext }}^{2}-R_{\mathrm{int}}^{2}(\theta)}\left(1+\frac{R_{e x t}^{2}}{r^{2}}\right)-\frac{R_{e x t}^{2}}{R_{e x t}^{2}-R_{\mathrm{int}}^{2}(\theta)}\left(1+\frac{R_{\mathrm{int}}^{2}(\theta)}{r^{2}}\right),
\end{gathered}
$$

In the formula (9) it is considered that the inner radius of the pipeline is a function of the polar angle, calculations are made, which allow to conclude that the change 
in the magnitude of the ring stresses is $10-12 \%$, which does not pose a threat to the structural strength.

\section{References:}

1. Olijnik A. P. (2010). Mathematical models of quasi-stationary deformation of pipeline and industrial systems when changing their spatial count configuration. Ivano-Frankivsk, Ukraine: IFNTUOG.

\section{HANDLING WITH CYBERCRIME}

\section{Oleksandr Pecheniuk}

Specialty: Cyber defence Faculty of IT and Computer Engineering Vinnitsa National Technical University

Cybercrime continues to be an ongoing threat for last few years. Today, cybercrime is a large-scale problem, and malware is written with the aim of illegally obtaining money. The development of the Internet has become one of the key factors determining these changes. Companies and individual users can no longer imagine their lives without it, and financial transactions are carried out via the Internet. Cybercriminals have realized the enormous potential for making money using malicious code in recent times, and many of the current fraudulent programs were written for sale to other criminals.

It should be emphasized that professional computer criminals choose local networks and servers of large companies as the crime object, in turn, "amateurs" encroach on the information of individuals' computers and less often "break" Internet service providers, as a rule, for "free" access to the Internet. It is not completely right to think that there is only one form of cybercrime to worry about (fraudsters stealing financial information). The list of concerns is far wider than that.

First of all what is cybercrime? Cybercrime is any type of fraud that takes place online, usually it targets computer networks or devices and can range from security breaches to identity theft. These methods can apply as to an individual user as well as to companies.

Knowing about the range of possible cybercrime commitment might force some corporations to hire an IT security officer to handle the cyber defence of firm, which would be smart idea as the threat behind cybercriminals is considerable.

The following types of cybercrime activities are possible and can occur:

A) Identity theft:

- Phishing: Attempting to access the user's personal data via fake emails, web pages or short messages, especially access to bank accounts and passwords;

- CEO-Fraud: Unknown people pretend to be bosses and try to get employees to send money or information;

- Counterfeit invoices: Fake invoices are sent by email;

- Preceded insolvency of business partners;

- Commercial register. 
B) Malware:

- Attached files via email that look harmless but contain malicious software. Mostly packaged in archive files.

- C) Network and Infrastructure attacks:

- DDoS attacks or botnet;

- Man-in-the-Middle attacks (type of attack when fraudster can read and edit messages, sent by any user, while they are not even aware of this).

Implementing a position of IT security officer is necessary to prevent an important data from stealing by cybercriminals. IT users in companies using the internet should be instructed about some basic precautions to be resistant to cyberattacks. All employees, who deal with different IT devices, have to confirm getting work instructions concerning cyber policy in writing. The objective of these guidelines is therefore the identification, analysis, avoidance and handling of fraud over the Internet, so with cybercrime in the financial sectors.

These documentaries contain detailed description of possible cyberattacks as well as possible measures for preventing them. Major activities are:

1) Accurate control of the sender's email address and phone number.

Often a scammer is already recognizable. Please go to the email address with the mouse pointer and check whether the display name and the email address match. Complying with safe Internet practices such as refraining from downloading from unknown sources and visiting sites with a low reputation is common sense in the prevention of cybercrime. A careful attitude to credentials and personal data can also significantly contribute to protection against intruders. However, the most effective protection method is still the use of a modern and high-quality anti-virus solution.

2) Using strong passwords.

It is advisable not to repeat passwords on different sites and make them complex (use a combination of at least 10 letters, numbers, symbols and cases). In addition, an encryption canbe used for password enhancement, which will decrease the hack probability significantly. Cybercriminals can use several ways to hack passwords and gain access to the account or device. The most common ways of password cracking are:

- Brute force (password crack method that lies in complete exhaustive search of all possible options to succeed);

- Dictionary attack (an attack on defence system that uses brute force method of assumed passwords, used for authentication and lies in consecutive overlook of all words in dictionary of certain length and view to hack the system and gain access to classified information);

- Social engineering (The psychological manipulation of people into performing actions of divulging confidential information).

3) Keeping software updated.

This is especially important with operating systems and internet security software. Cybercriminals frequently use known exploits, or flaws, in software to gain access to system. Patching those exploits and flaws can make an attack less likely to happen.

4) Manage social media settings. 
80 • Problèmes et perspectives d'introduction de la recherche scientifique innovante $\bullet$ Volume 2

Keep personal and private information locked down. Social engineering cybercriminals can often get personal information with just a few data points, so do not share this kind of information publicly. For instance, if you post pet's name or reveal your mother's maiden name, might expose the answers to two common security questions.

5) Defense of company network.

It is recommended to start with a strong encryption password as well as a virtual private network. A VPN will encrypt all traffic leaving devices until it arrives at its destination. If cybercriminals do manage to hack communication line, they will not intercept anything but encrypted data.

Besides, these guidelines for IT users include a prescribed work behavior for definite kinds of companies' staff (IT users, their direct supervisors IT departments and IT security officers).

\title{
References:
}

1. Cybercrime and cybersecurity strategies in the Eastern Partnership region. (2018). Updated report, European Union.

2. IDG Contributor

Network.

(2019).

Retrieved

from

https://www.csoonline.com/article/3403657/forthright-handling-of-cybercrime-essential-to-

improved-results.html 15.11.2019.

DOI 10.36074/29.11.2019.v2.09

\section{MODELING OF THE WELD POOL FORMATION DURING SURFACING WITH STRIP ELECTRODE}

\begin{abstract}
Vitaliy Ivanov
$\mathrm{PhD}$, Associate Professor of the Department of Automation and Mechanization of Welding Production State Higher Educational Institution «Priazovskiy State Technical University»

Elena Lavrova

$\mathrm{PhD}$, Associate Professor of the Department of Automation and Mechanization of Welding Production State Higher Educational Institution «Priazovskiy State Technical University»
\end{abstract} UKRAINE

To build an improved model for the formation of a penetration zone during strip welding and surfacing, it is necessary to take into account the influence of convection flows of liquid metal in the weld pool and introduce into the system of equations of the model quantitative dependences of the effect of convection heat, mass and momentum transfer on the temperature distribution in the base metal depending on the spatial location of the considered point and time of action of the heating source.

It is convenient to consider the formations of the weld pool when using a strip electrode as an example of comparison with the case of multi-electrode surfacing 
by electrode wires arranged in a row with a common current supply. In both cases, the welding arc is formed alternately at the ends of the strip or wire electrodes, which leads to an uneven distribution of heat input and penetration depth across the width of the bath at each individual time [1,2]. This also explains the uneven penetration along the width of the roller so that the parameters of the arc burning differ depending on its location along the width of the pool. So, in most cases, at the edges of the bead, the base metal is melted to a greater depth, respectively, in the outside electrodes a greater amount of flux is melted. This is confirmed by macro sections of deposited beads and fractures of the slag crust in them [3-5].

In multi-electrode arc welding, it is difficult to provide the same melting conditions for all electrodes. For strip electrodes, this situation persists for various reasons - potential distribution, uneven arc length at the edges and in the middle of the strip, conditions for heating the electrode with current, a larger temperature gradient, etc.

In this case, the non-uniform penetration through the width and volume of the weld pool can be explained by the fact that the melting region of a strip or several wire electrodes should not be considered as a single zone of molten metal with a common distribution of forces and flows, but as a combination of individual local pools formed by short-term arc burning and electrode metal transfer, but form a common interaction zone, which is characterized by uneven heat input not only in length but also in width. Therefore, the pattern of formation in the weld pool during strip welding and surfacing can be represented as a set of axisymmetric electrodes alternately existing along the line of the tape profile (Fig. 1).

Such batch melting of the electrode in each section, which is also distributed across the width, leads to a significant decrease in both the depth and the area of the penetration zone (for each section) with an increase in the total values of the areas of penetration and surfacing. Accordingly, with this process, a decrease in the melting rate of the strip (wire) electrode is observed, which confirms the thesis about the determining influence of the feed rate (melting) on the penetration depth of the base metal.
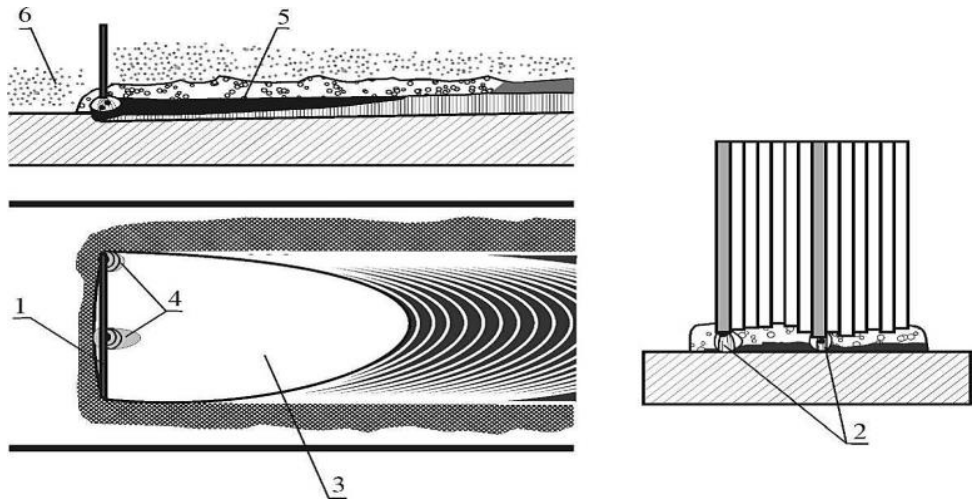

Fig. 1. The scheme of the weld pool formation during surfacing with a strip electrode:

1 - strip electrode; 2 - arc; 3 - weld pool; 4 - local weld pool; 5 - slag pool; 6 - flux 
Conclusions. The influence of the feed speed of the strip electrode on the penetration depth of the base metal is confirmed. It is proved that with an increase in the total values of the areas of penetration and surfacing leads to a significant decrease in both the depth and the area of the penetration zone.

\title{
References:
}

1. Lavrova E.V., Ivanov V.P. (2018). Controlling the Depth of Penetration in the Case of Surfacing with a Strip Electrode at an Angle to the Generatrix. Materials Science Forum, (938), 27-32.

2. Ivanov V.P., Lavrova E.V. (2014). Improving the Efficiency of Strip Cladding by the Control of Electrode Metal Transfer. Applied Mechanics and Materials, (682), 266-269.

3. Kumar V., Lee C., Verhaeghe G., Raghunathan S. (2010.) CRA Weld Overlay - Influence of welding process and parameters on dilution and corrosion resistance. Stainless Steel World America, 64-71.

4. Jingnan Peng, Lixin Yang. (2016). The Mathematical Model Research on MIG Groove Welding Process. Retrieved from https://doi.org/10.1016/j.proeng.2016.08.377

5. Wenzhe Chen, Xipeng Xu, Pinqiang Dai, Yonglu Chen, Zhengyi Jiang (2012). The Mathematical Model of Welding Process Comparative Study of Identification Method. Advanced Materials Research, (472-475), 2241-2244.

\section{MODERN POTENTIAL AND ECONOMIC OPPORTUNITIES OF MANAGING ALTERNATIVE ENERGY SOURCES}

\author{
Alexander Kustov \\ Master's student \\ Lipetsk State Technical University \\ RUSSIAN FEDERATION
}

As you know, there are traditional and unconventional electricity sources. The traditional method of generating electricity is to use of thermal power stations (TPS), hydroelectric power stations (HPS), nuclear power stations (NPS). In turn, unconventional methods use the energy of the sun, wind, biomass and water. Having analyzed the data for the previous two years (Fig. 1), we can see that alternative energy is actively developing. In 2018, renewable energy sources (RES) already accounted for $47 \%$ of the annual increase in electricity generation $(\sim 442$ Tw).

If we compare the share of RES in the power balance by states, we can see that Russia is only sixth in the development and introduction of alternative energy sources (Fig. 2). Leading place belongs to Germany. The amount of energy generated by RES already exceeds more than $30 \%$ of all electricity generated in the country. 

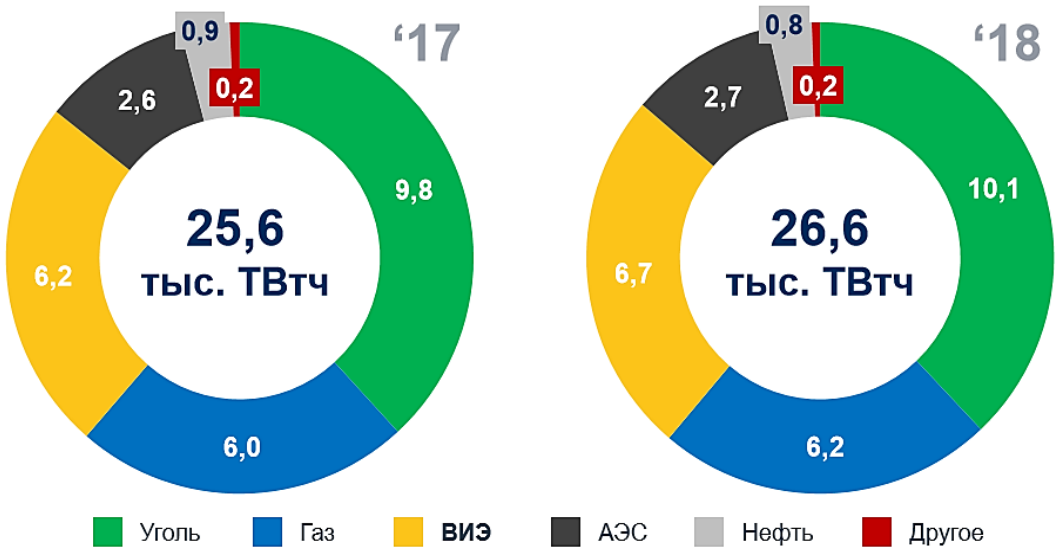

Fig. 1. Share of renewable energy in the world

Recently, Russia has been actively trying to expand and support the development trend of this industry, introducing support programs [1]. Due to the active development in this industry, there is competition between investors. As a result, the cost of projects is steadily decreasing. If you pay attention to the government's plans for 2024, you can see the following data on wind farms and solar power station (SPS) shown in fig. 3 and 4.

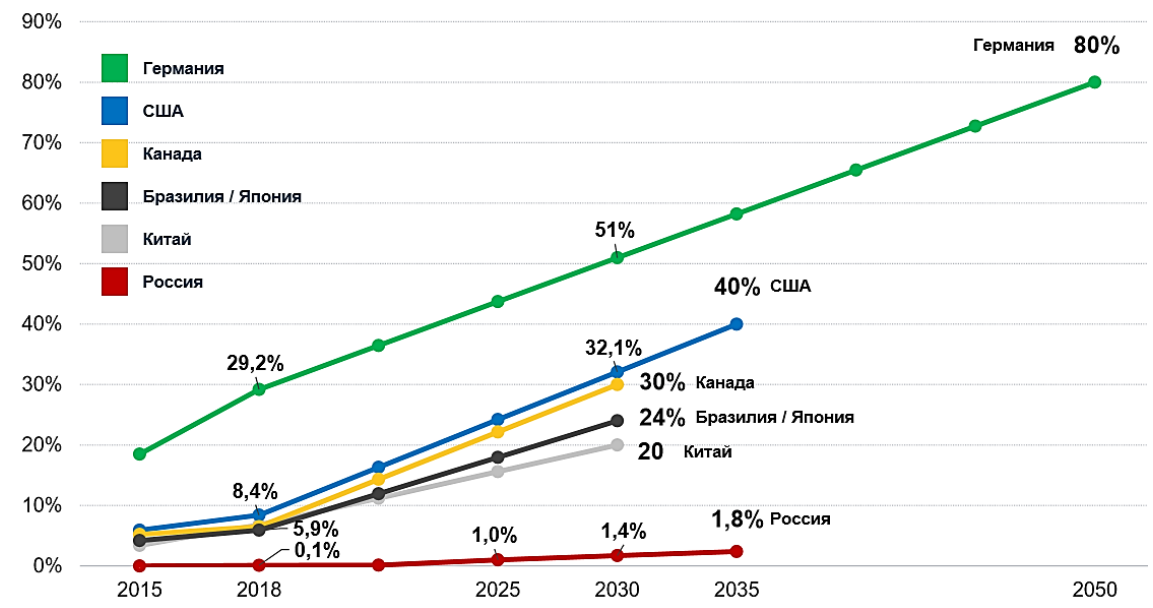

Fig. 2. The percentage of RES to traditional energy sources from 2015 to 2035 


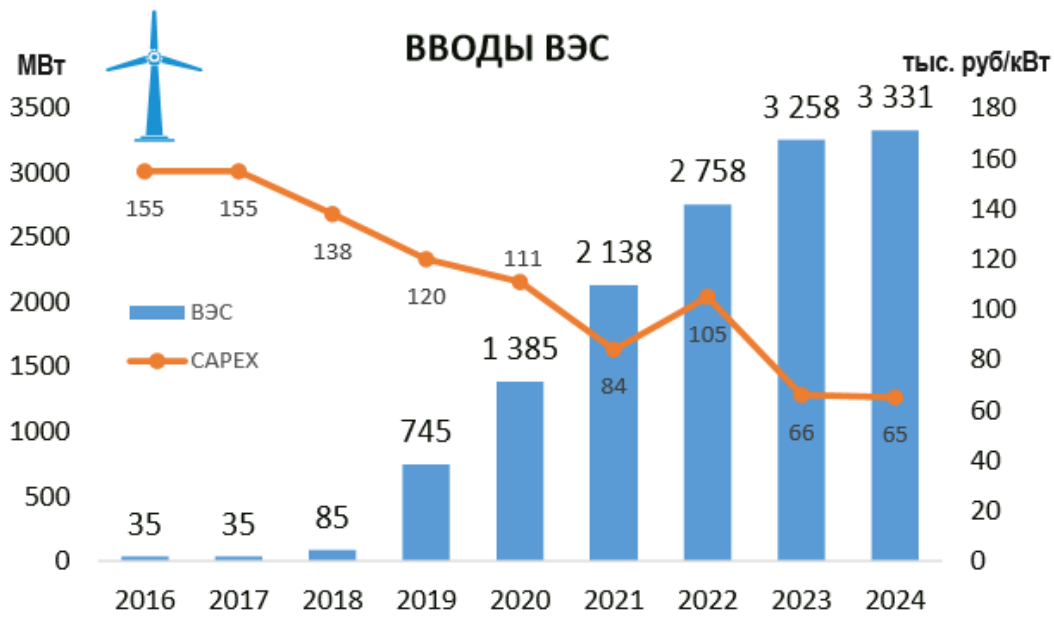

Fig. 3. Parameters of the wind farm cluster by 2024

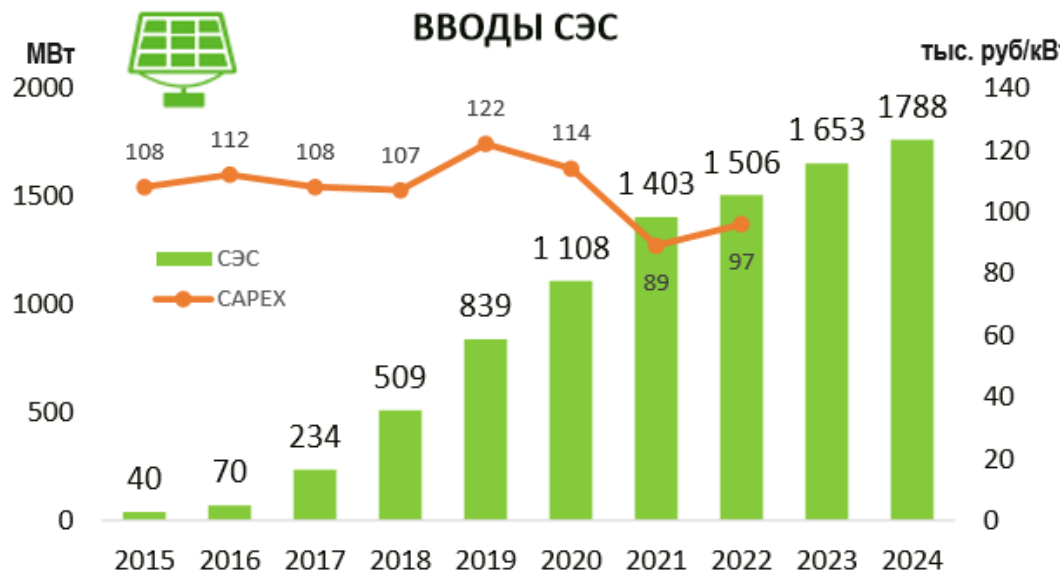

Fig. 4. Parameters of the SPS cluster by 2024

You can see the economic effect from the above graphs. It consists in reducing CAPEX (CAPital EXpenditure) and achieving parity LCOE (Levelised Cost of Energy RES with traditional generation) [2, 3].

RES support system is divided into three stages:

- Renewable energy supply contract 1.0 - calculated by the state for the period 2013-2024. This stage implies a mechanism for a power supply contract (PSC), localization requirements, support in the retail market;

- Renewable energy supply contract 2.0 - calculated by the state for the period 2024-2035. This stage involves the PSC mechanism, "Green" certificates, 
improving support in the retail market and isolated electricity systems;

- Achieving parity LCOE RES and traditional generation. This stage involves increasing the depth of localization, supporting the export of equipment, stimulating voluntary demand among consumers and finding ways to reduce credit rates.

According to the calculation results, taking into account the first and second planned stages (RES supply contract 1.0 and 2.0), the normalized average cost of electricity production over the entire life cycle of a power plant (LCOE RES) will decrease (Fig. 5 and 6).

$$
\mathrm{LCOE}=\frac{\sum\left(\mathrm{Cap}_{\mathrm{t}}+\mathrm{O} \& \mathrm{M}_{\mathrm{t}}+\mathrm{F}_{\mathrm{t}}+\mathrm{Carb}_{\mathrm{t}}+\mathrm{D}_{\mathrm{t}}\right) \cdot(1+\mathrm{r})^{-\mathrm{t}}}{\sum \mathrm{MWh}_{\mathrm{t}} \cdot(1+\mathrm{r})^{-\mathrm{t}}}
$$

$\mathrm{MWh}_{\mathrm{t}}$ - the amount of electricity generated for the year $\mathrm{t} ;(1+\mathrm{r})^{-\mathrm{t}}-$ the coefficient of discounting for the year $\mathrm{t}$; $\mathrm{Cap}_{\mathrm{t}}$ - the total capital costs incurred for the year $t ; \quad O \& M_{t}$ - the operational expenditures for the year $t ; F_{t}$ - the fuel costs for the year $\mathrm{t}$; Carb $\mathrm{t}_{\mathrm{t}}$ - the greenhouse gas costs for the year $\mathrm{t} ; \mathrm{D}_{\mathrm{t}}$ - the costs of solving waste-disposal problem for the year $t$.

Thanks to support programs and high competition in this market, this direction will be actively developing, and as it was indicated earlier in the forecasts, the share of alternative sources will increase, which in turn will mean a decrease in electricpower generation in the traditional way, this will entail a reduction in $\mathrm{CO} 2$ emission (Fig. 7).

The decrease in LCOE RES (SPS / wind farm) in Russia is in line with global dynamics. Achievement of the competitiveness in cost of RES (SPS / wind farm) with traditional generation is forecasted by 2035 .

\section{LCOE BЭC, руб./КВТ·ч}

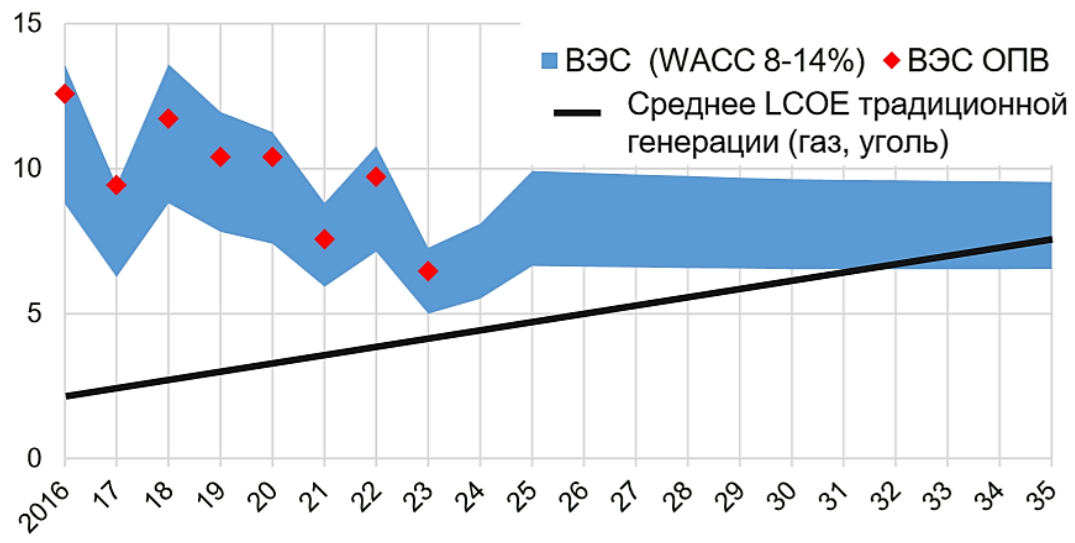

Fig. 5. Standardized cost of electricity LCOE wind farm 


\section{LCOE CЭC, руб./кВт·ч}

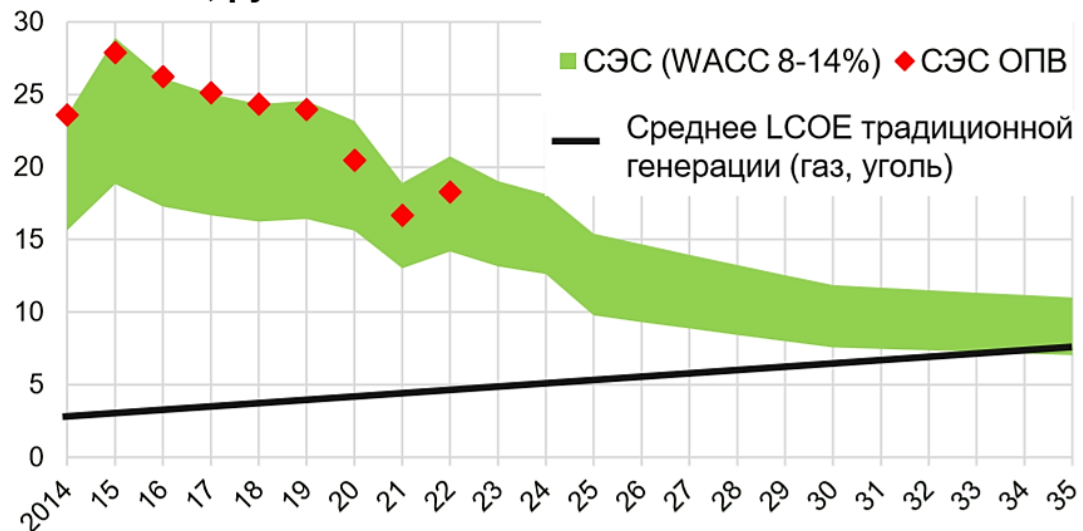

Fig. 6. Standardized cost of electricity LCOE SPS

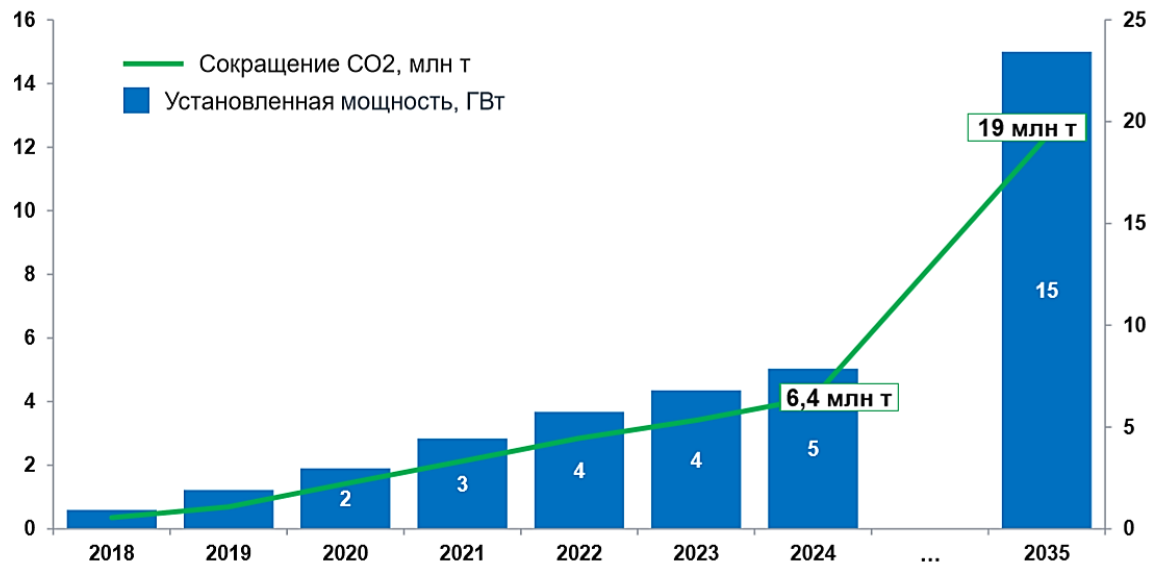

Fig. 7. The impact of renewables on reducing $\mathrm{CO} 2$ emissions

If we consider the prospects for the development and implementation of alternative sources in the Lipetsk region (based on the resolution of the administration of the Lipetsk region dated November 7, 2013 №499 «On approval of the state program of the Lipetsk region" Energy Efficiency and Energy Development in the Lipetsk Region"» (as amended on January 18, 2019)), you can see that street lighting is actively reconstructed to introduce solar modules in the region, active monitoring of solar activity and wind load. In the near future, all this will allow more efficient placement of wind installations (wind farm), as well as give prospects for the wider introduction of solar modular installations $[4,5,6,7]$. The implementation of this project will allow the region to become less dependent on traditional power sources, reduce $\mathrm{CO} 2$ emissions and maintenance costs of the 
electric grid complex.

Conclusion:

- the introduction of alternative sources will entail the intensive development of the scientific and technical potential of the renewable energy industry;

- increasing the competitiveness of the industry in domestic and foreign markets;

- development of high-tech export of renewable energy engineering;

- a significant reduction in CO2 emissions;

- Decrease in LCOE RES (SPS / wind farm);

- increased economic effect in reducing CAPEX.

\title{
References:
}

1. Kustov, A. N., Zatsepina, V. I. (2019). «Improving efficiency in the electric grid complex». Energysaving and efficiency in technical systems, 1, 252-253.

2. RUSNANO. (2019). Annual reports. Retrieved from https://www.rusnano.com.

3. BP Stat Review of world energy. (2019). Annual reports. Retrieved from https://www.bp.com.

4. The development of alternative energy and energy conservation in the world tion. (2009). Moskow: All-Russian Market Research Institute.

5. On the development of wind energy of the Russian Federation. (2009). Moskow: All-Russian Market Research Institute.

6. On the development of solar energy in the world. (2009). Moskow: All-Russian Market Research Institute.

7. On the development of alternative energy sources in the countries of the Near and Middle East. (2009). Moskow: All-Russian Market Research Institute.

\section{NODEMCU ЯК ПЛАТФОРМА ДЛЯ РОЗУМНОГО БУДИНКУ}

\begin{abstract}
Лісогір Юлія Миколаївна
здобувач освіти молодшого спеціаліста

відділення комп'ютерно-інтегрованих технологій Машинобудівний коледж Донбаської державної машинобудівної академії

Науковий керівник: Сагай Ольга Володимирівна

Викладач вищої кваліфікаційної категорії, методист

Машинобудівний коледж Донбаської державної машинобудівної академії

УКРӒ̈HA
\end{abstract}

У світі сучасних технологій, що динамічно розвиваються, актуальне питання розумних будинків. Ця система створена для покращення умов проживання та полегшення щоденних клопотів у побуті, економії часу і коштів. «Розумний будинок» - це високотехнологічна система, яка може об'єднати всі комунікації вашого дому, і керувати ними одним натисканням кнопки. Освітлення, опалення, сигналізація, відеонагляд - це далеко не всі системи, якими можна керувати з допомогою «розумного будинку». 
88 • Problèmes et perspectives d'introduction de la recherche scientifique innovante $\bullet$ Volume 2

Розумний будинок це вже не новинка, але пропозиції та технології, які зараз $€$ на ринку доволі не дешеве задоволення. Тому в ході дослідження нашою метою буде обрати кращу версію модуля як дешеву альтернативу розумного дому.

Розглянемо модуль NodeMCU. Це платфрорма з відкритим вихідним кодом ІоT. Він включає прошивку, яка працює на ESP8266 Wi-Fi SoC від Espressif Systems і апаратне забезпечення, засноване на модулі ESP-12. Термін «NodeMCU» за замовчуванням ставиться до прошивки, а не до комплектів розробки. Прошивка використовує мову сценаріїв Lua. Biн заснований на проекті eLua і побудований на Espressif Non-OS SDK для ESP8266. Також використовує багато проектів з відкритим вихідним кодом, таких як lua-cjson, I spiffs.

Технічні характеристики модуля наступні:

- підтримує Wi-Fi протокол $802.11 \mathrm{~b} / \mathrm{g} / \mathrm{n}$;

- підтримувані режими Wi-Fi - точка доступу, клієнт;

- вхідна напруга 3,7 B - 20 B;

- робоча напруга 3В-3,6;

- максимальний струм 220мА;

- вбудований стек ТСР / IP;

- діапазон робочих температур від -40С до 125C;

- 80МГц, 32-бітний процесор;

- час пробудження і відправки пакетів 22МС;

- наявність підсилювачів потужності, регуляторів, систем управління живленням.

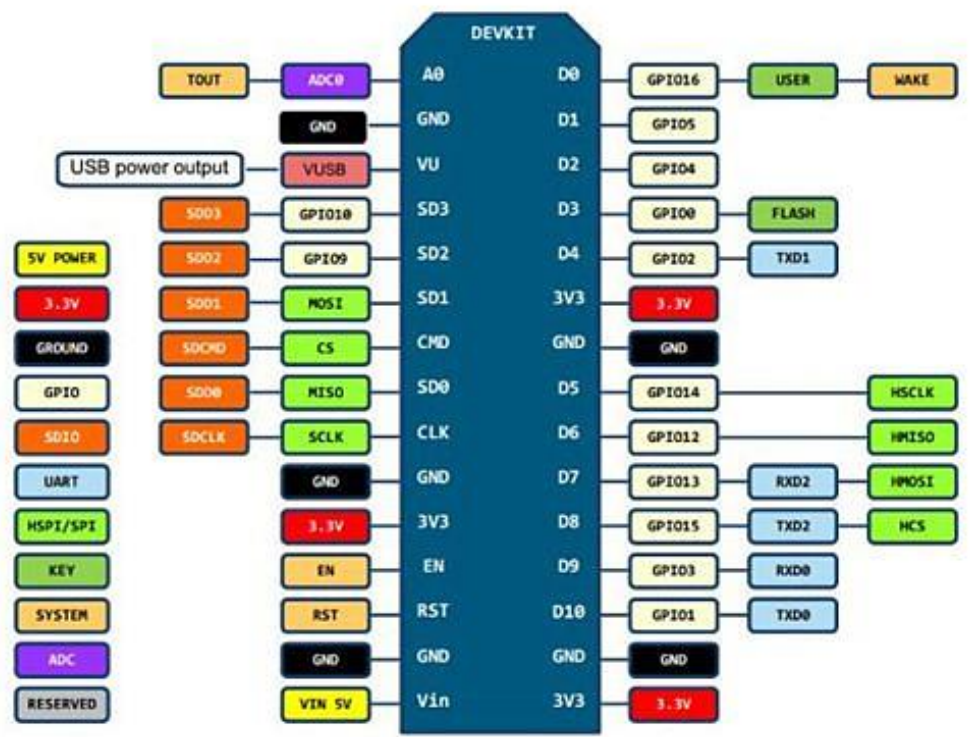

Pис. 1. Pinout NodeMCU 
Існує кілька поколінь плат NodeMCU - V1 (версія 0,9), V2 (версія 1.0), і V3 (версія 1.0). Позначення V1, V2, V3 використовуються при продажу в інтернетмагазинах. Нерідко буває плутанина в платах - наприклад, У3 зовні ідентична V2. Також всі плати працюють за принципом open-source, тому їх можуть виробляти будь-які фірми.

Модуль V3 має 11 контактів введення-виведення загального призначення. Крім цього деякі з висновків володіють додатковими функціями:

- D1-D10 - висновки з широтно-імпульсною модуляцією;

- D1,D2 - висновки для інтерфейсу I²C/TWI;

- D5- D8 - висновки для інтерфейсу SPI;

- D9, D10 - UART;

- АО - вхід з АЦП.

Висновки. Отже в ході дослідження було обрано кращу версію модуля, яка має ряд переваг:

- наявність інтерфейсу UART-USB з роз'ємом micro USB дозволяє легко підключити плату до комп'ютера;

- наявність фрлеш-пам'яті на 4 Мбайт;

- можливість оновлювати прошивку через USB;

- можливість створювати скрипти на LUA і зберігати їх в файлової системі.

Тому саме цей модуль $є$ найкращою альтернативою дорогим аналогам модулів для розумного будинку.

\section{Список використаних джерел:}

1. NodeMCU. Retrieved from https://ukr.segodnya.ua/lifestyle/science/umnyy-dom-v-ukraine-vseplyusy-i-minusy--1101886.html.

2. «Розумний будинок». Вилучено з http://journals.uran.ua/atbp/article/download/32920/29533.

3. NodeMCU. Вилучено з https://ru.wikipedia.org/wiki/ESP8266.

4. Pinout NodeMCU. Вилучено 3

5. https://arduinomaster.ru/wp-content/uploads/2017/12/nodemcu-pin.jpg.

\section{OUTLOOK «GREENING» OF HYDRAULIC FRACKING TECHNOLOGY FOR THE PRODUCTION OF UNCONVENTIONAL HYDROCARBONS}

Sergiy Oveckiy $\mathrm{PhD}$, Associate Professor, Senior Lecturer at Department of Production of Oil and Gas Institute of Petroleum Engineering Ivano-Frankivsk National Technical University of Oil and Gas UKRAINE

The sustainable development strategy of the world in general, and of Ukraine in particular, envisages the formation of principles of a "green" economy. The green economy is a practical mechanism for the implementation of a sustainable development strategy, which involves reducing the negative impact on the 
environment by forming new green industries and greening existing ones. Among the existing ones, the resource sector, namely the oil and gas component, is one of its environmental hazards and importance for economic growth. Due to the reduction of extraction of energy resources from traditional fields, humanity is increasingly paying attention to the extraction of fossil fuels from so-called unconventional deposits. Among the unconventional ones, tight hydrocarbons, shale rocks, and gas of coal seams are considered to be particularly promising. These fuel resources are an important source of achieving the Sustainable Development Goals of Ukraine, in particular, Goal 7.2.1, reducing the share of oil and gas imports by 2025 from 40 to $12 \%$ [1]. It should also be remembered that the extraction of unconventional oil and gas is often impossible without the use of hydraulic fracturing technology (fracking), which can adversely affect other goals related to environmental sustainable development of Ukraine, namely [1]:

1. The proportion of rural people who have access to safe drinking water (Goal 6.1.1) should increase from 50 to $100 \%$. The use of fracking can not lead to the loss of drinking water while observing the necessary technological parameters for cementing the surface and the protection casing, as well as the fact that most unconventional hydrocarbons can be extracted from depths significantly exceeding the depth of underground freshwater reservoirs (up to $400 \mathrm{~m}$ ).

2. It is necessary to achieve a neutral level of land degradation by 2030 (Goal 15.3.1). Unconventional fields use shrub-boring of horizontal wells, which allows the use of a minimal number of drilling and production sites, even compared to traditional mining. In addition, there is only one known case of soil subsidence, not during but after fracking [2], due to improper disposal of waste water and failure to account for existing geological faulting. This process was accompanied by slight fluctuations in the crust of up to 2 points, although usually during fracking fluctuations are recorded as microseismic and can not cause the destruction of buildings.

3. To reduce the level of the reservoir of GDP (Goal 6.4.1) from 3.6 to $2.5 \mathrm{~m}^{3}$ per $1000 \mathrm{UAH}$ of GDP. When extracting hydrocarbons from unconventional fields using fracking technology, $10-15 \%$ less water is used than when using similar technology for traditional hydrocarbons (this is due to greater water absorption of traditional fields), and several times less than when rapeseed is grown ( to produce biodiesel per 1 ton of fuel).

4. The share of polluted water discharges in the total discharges should be reduced (Goal 6.3.2) from $15.7 \%$ to $5.0 \%$. In addition to water and proppant (97$99 \%$ of the composition of fracking fluid), which is usually used sand, $1-2 \%$ of other substances are also used, which are also used in agriculture, food and light industry. One of the few exceptions to these substances is lubricants for fracturing fluids.

Therefore, the development of environmentally friendly lubricants should be the main focus of greening fracking technology for unconventional hydrocarbons.

\section{References:}

1. Міністерство економічного розвитку і торгівлі України. (2017). Цілі сталого розвитку: Україна. Національна доповідь. Вилучено 3 https://menr. gov.ua/files/docs/НаціональнадоповідьЦСРУкраїни_липень2017ukr.pdf.

2. Рябцев, Г. Л., Сапегин, С. В., Кривогуз, М. И. (2014). Нетрадиционные углеводороды: настоящее и будущее. Киев: Психея. 


\title{
PREREQUISITES OF THE VALUE-ENTROPY APPROACH TO PROJECT ORGANIZATION MANAGEMENT
}

\author{
Alla Bondar \\ Cand. tech. sciences, Associate Professor, \\ Department of logistics systems and projects management \\ Odessa National Maritime University
}

UKRAINE

Today's science has two global trends - the transfer of concepts and methodologies from different fields of knowledge and the dissemination of individual categories at different levels and objects within the same field of knowledge. Modern science blurs the boundaries between the fields of knowledge and their levels, forming a unity of conceptually-methodological approaches to the study of different objects, processes or phenomena. It should be noted that the project methodology, originally inherent in project organizations, has successfully proven itself in practice in managing diverse organizations, in their essence and scale. This gave a powerful impetus to the development of the theory of project-oriented organizations. Thus, the methodology and tools of project management are being disseminated, developed and advanced, covering all types of enterprises, companies and organizations. Today, project methodology is becoming a leading management concept that provides appropriate tools for organizations of various fields of activity, both commercial and non-commercial, transforming them into project-oriented.

It should also be noted that one of the mainstream in project management is the value category, which is currently used to characterize projects. This category is widely used in the theory and practice of project management due to its versatility, as it allows you to evaluate projects regardless of their nature and subject area. Thus, "project value" is a universal category that can be transformed into classic economic efficiency, giving monetary or any other assessment of the effect of implementation, such as social or environmental projects. Following the logic of systematicity, the constituents of any organization can also be characterized by value, with both resources in the aggregate and each individual entity.

A prime example of concept transfer is entropy and its use in managing organizations. Thus, examples of publications that have considered entropy in this context are $[1,2]$.

However, most studies do not provide clearly structured postulates of an "entropy" approach to managing organizations. This is because the "intuitive" understanding that everything happening in our world is subject to the same global laws requires time for clear awareness, identification and research.

Conclusion. Today there is a need for further development of ideas of value and entropy approach. Since the categories of entropy and value are systematically interrelated, then their integral consideration is applied to project-oriented organizations. 


\title{
References:
}

1. Busheyev S. D. \& Busheva N. S. (2009). Formation of value in the activities of project-oriented organizations. Project Management and Production Development, (3.31), 5-14. [in Ukrainian]

2. Molokanova V. M. (2012). Research of project-oriented development on the basis of evolutionary theory of value. Project Management and Production Development, (2.42), 11-17. [in Ukrainian]

3. Shakhov A. V. (2014). Entropy model of portfolio management of a project-oriented organization. Project Management and Production Development, (2.50), 87-95. [in Russian]

4. Likhonosova G. S. (2018). Entropy balancing: a tool for eliminating socio-economic exclusion in the enterprise. Journal of Economic Reform, (2,30), 43-51. [in Ukrainian]

\section{PROSPECTS FOR THE USE DRY PLANT MILK IN THE PRODUCTION OF DESSERTS}

\author{
RESEARCH GROUP: \\ Maksym Maletskyi \\ student of the Department of Food Technologies \\ Oles Honchar Dnipro National University \\ Anastasiia Nalyvaiko \\ student of the Department of Food Technologies \\ Oles Honchar Dnipro National University \\ Anastasiia Handuchka \\ student of the Department of Food Technologies \\ Oles Honchar Dnipro National University \\ Katerina Suprunenko \\ assistant of the Department of Food Technologies \\ Oles Honchar Dnipro National University \\ Scientific advisor: Nataliia Kondratiuk \\ Candidate of Engineering Sciences, Associate Professor, \\ Head of the Department of Food Technologies \\ Oles Honchar Dnipro National University \\ UKRAINE
}

Plant milk is a protein-fat emulsion which manufactured from plant raw materials. Organoleptic characteristics of the plant milk are as close as possible to dairy milk. Feature of plant milk is lack of lactose. This fact is very important for peoples with lactose intolerance. It should be noted, plant milk is important source of proteins for vegans and for peoples who fast.

This type of products can classify by raw materials used: wheat

- Grains: barley, fonio, maize, millet, oat, rice, rye, sorghum, teff, triticale, spelt,

- Pseudocereals: amaranth, buckwheat, quinoa

- Legumes: lupin, pea, peanut, soy

- Nuts: almond, brazil, cashew, hazelnut, macadamia, pecan, pistachio, walnut 
- Seeds: chia seed, flax seed, hemp seed, pumpkin seed, sesame seed, sunflower seed

- Other: coconut (fruit; drupe), potato (tuber), tiger nut (tuber) [1].

Plant milk has a similar chemical composition with dairy milk. This explains high popularity nondairy milk from plants.

Based on amino acid composition data of plant milk, was concluded that it sufficiently satisfies the need for essential amino acids.

Milk pudding is a popular dessert. It differs from other types of desserts for soft texture, delicate consistency and low fat. But this type of desserts contains a lot of sucrose. The presence of sucrose determines the density and stability of the whipped mass.

Nowadays there are technologies for making puddings which base on different kinds of plant milk such us coconut milk, hazelnut milk, oat milk [2, 3]. There are also semi-finished products in the form of a dry mixture for the preparation of pudding.

The composition of the dry mixture for the preparation of the pudding includes sugar, starch for thickening and milk powder. The presence of these ingredients does not allow recommending this product to people with diabetes and obesity. The existing technology for the production of pudding from plant milk is focused on use in the restaurant business and cannot be adapted for the production of dry semifinished products of a high degree of readiness.

Based on the existing technology for the production of dry semi-finished products for the preparation of puddings, a formulation of a dry mixture based on vegetable milk was developed. kappa-carrageenan has been used as a thickener in the food system. (представитель семейства линейных сульфатных полисахаридов), получаемых из красных морских водорослей, позволяющих получить плотные гели за счёт малого содержания сульфатных групп (одна сульфатная группа на две молекулы галактозы).

A mixture of erythritol and a sweet extract of stevia leaves were used instead of sugar. The ratio of the components of the mixture was $6: 1$. This mixture does not have a bitter aftertaste from stevia. Samples of the new product were made on the basis of dried coconut milk, rice milk and their mixture 1:1. Rice and coconut pudding is very popular among people in Western Europe and South America.

Table 1 shows the formulation of food concentrate for the preparation of puddings.

Table 1

Formulation of food concentrates for the preparation of puddings

\begin{tabular}{|c|c|c|c|}
\hline \multirow{2}{*}{ Name of ingredient } & \multicolumn{3}{|c|}{ Share in the finished mixture g/100 g of finished product } \\
\cline { 2 - 4 } & Sample № 1 & Sample № 2 & Sample № 3 \\
\hline Kappa carrageenan & 4 & 4 & 4 \\
\hline Dry rice milk & 0,6 & - & 0,3 \\
\hline Dry coconut milk & - & 0,6 & 0,3 \\
\hline «Sweet extract of stevia» & 0,5 & 0,5 & 0,5 \\
\hline Erythritol & 3 & 3 & 3 \\
\hline Natural flavor «Cream+» & 0,1 & 0,1 & 0,1 \\
\hline
\end{tabular}

To reduce calorie content the absence of sugar and starch in the mixture allows. to obtain the finished product, add $100 \mathrm{~g}$ of water, mix, boil the mixture until a thick mass is formed. The resulting product can also be baked. 
The developed technology allows the making of a range of products for people suffering from type 2 diabetes, obesity, overweight, lactose intolerance.

\section{References:}

1. Swati, Sethi, Tyagi,S.K., Rahul, K. Anurag/ (2016). Plant-based milk alternatives an emerging segment of functional beverages: a review. J Food Science Technology. №53 (9), 3408-3423.

2. Panacota with raspberries and coconut milk Sweet Fantasy 120 г, Russia (2019). Азбука вкуса. Retrieved from https://av.ru/i/403696/

3. Cashew and Coconut Milk Pudding. (2019) Vegeterian: Retrieved from https://vegetarian.ru/recipes/puding-na-moloke-iz-keshyu-i-kokosa

\section{DOI 10.36074/29.11.2019.v2.10}

\section{THE LEAN MANUFACTURING SYSTEM AS A CONCEPT OF ENTERPRISE MANAGEMENT}

Helen Zotova

the Head of Operation Department, economic disciplines lecturer, Poltava Oil and Gas College National University "Yuri Kondratyuk Poltava Politechnic»

Volodymyr Kryts'kyy special disciplines lecturer

Poltava Oil and Gas College National University «Yuri Kondratyuk Poltava Politechnic»

UKRAINE

Lean (lean production, lean manufacturing) - the concept of production enterprise management, based on the constant desire to eliminate all kinds of losses. Reliable production involves engaging every employee in the business optimization process and maximizing customer focus [1].

Lean manufacturing is a management concept based on the enterprise's constant desire to reduce all kinds of losses, that is, nothing extra. Lean - means doing more with less effort.

Lean is based on the Toyota production system developed in the 1950s. The use of lean manufacturing has helped Toyota achieve significant business success.

Leading global and domestic companies are actively introducing lean manufacturing practices in the energy and other industries.

The goal of lean manufacturing is to maximize the share of value-creating actions and the reduction of loss and forced labor.

In each production process there are from 1 to 8 types of losses that reduce its efficiency: overproduction, expectations, transportation, over-processing, inventories, refinement of defects, unnecessary movements or displacement, untapped potential.

$5 \mathrm{C}$ is a Lean tool that allows you to maintain an efficient workspace in the manufacturing and office space that lays the foundation for a productive culture.

The $5 \mathrm{C}$ system derives its name from 5 classic principles, each beginning with the letter "C":

1. Sorting.

2. Creating a workplace. 
3. Creating purity.

4. Standardization.

5. Systematic improvement.

Consider the principles of rational organization of the workplace:

- Get rid of unnecessary: unnecessary items lead to loss space, time and money.

- Every thing in its place: Arrange the objects so that they are there easy to find and use.

- Keep your workplace clean: Make your place comfortable and clean.

- Create a standard of workplace, operations: standardize everything improvements.

- Continually improve your workplace: Build a system an integral part of the workflow.

Thus, the leader in the implementation of Lean production system in the oil and gas industry is JSC "Ukrgasvydobuvannya", whose mission is to ensure energy security and energy independence of Ukraine by developing its own gas resource potential, developing internal technological competence and a reliable ecosystem of the industry.

The basic principles of lean manufacturing are:

- respect your colleagues;

- continually improve yourself.

The lean production is aimed at improving the key performance indicators of Ukrgazvydobuvannya in all directions.

$\mathrm{UHV}$ is constantly seeking to reduce all types of losses. Therefore, the company continues to actively implement the Lean proven business organization and management system [2].

The main task of implementing $1 \mathrm{C}$ : sorting - to divide everything in the work area into three categories: constantly used for basic tasks, not used at all, rarely used, but may be required. If in doubt about an item, remove it immediately from the work area.

Options to help you assess the need for the item:

- the necessity of the subject when performing the current activity: if the item is not needed, it must be removed from the work area;

- the frequency with which the item is used: if the item rarely used, it can be stored outside the workplace;

- the number of items required for current activity: if a limited amount is required, then the excess is removed or stored outside the workplace.

Implementing 2C: Creating a Workplace - it is about locating and placing the necessary things so that they are easy to use, find, and return.

Creating a workplace is inextricably linked to sorting - when all the items are sorted, only those that are really needed for the current job are left. That is, the workplace must ensure maximum efficiency.

Implementation of 3C: creating cleanliness - means finding problematic places in the workplace cleaning process, as well as keeping it clean in order to get a clean and tidy workplace that is enjoyable to work with; keeping everything you need to accomplish your current production tasks in the perfect order, minimizing the time spent locating losses.

4C implementation: standardization - is to establish the principles and standards for adhering to the first three stages of $5 \mathrm{C}$. The purpose is to identify and visualize clear and simple rules that are required to support and further improve the workplace. 
$96 \bullet$ Problèmes et perspectives d'introduction de la recherche scientifique innovante $\bullet$ Volume 2

The standard is the basis of the lean manufacturing and continuous improvement system.

Implementation of 5C: systematic improvement - means maintaining discipline, constantly improving standards. That is, responsibility should be established for the fact that "everything must be done the way it should be done" - creating a quality workplace should become a habit.

Systematic training on lean production is ongoing at UHV. Employees of the branches of joint-stock company JSC: Ukrburgaz, Ukrgaspetsbudmontazh, Shebelynkagazvydobuvannya, Lvivgazvydobuvannya, Poltavagasvydobyvaniya gain new knowledge [3].

Thus, one of the first steps towards the deployment of lean production is the introduction of a system of workplace organization - system $5 \mathrm{C}$ on the basis of HPU "Poltavagazovydobuvannya". At the HPU, trainings are held for management, employees of all branches on the basic goals and principles of Lean, namely:

- increase of productivity of basic processes;

- increase of reliability of the basic equipment;

- reduction of operating expenses;

- raising the level of production culture;

- standardization of business processes;

- reduction of labor costs [2].

The trainings are part of a large-scale project implemented by specialists of operational efficiency departments with the support of HR department [3].

Students of Poltava Oil and Gas College National University «Yuri Kondratyuk Poltava Politechnic» also participated in the study of Lean Production system 5C.

Future experts in the oil and gas industry listened to a theoretical course on the topic: "Introduction of lean production system", which was presented by leading experts of the operational efficiency department of the HPU "Poltavagazvydobuvannya" and UHV-Service.

During the training, students learned about the basic ideas and tools of Lean: (5C system, visualization, standardization, comprehensive approach to equipment care, modern approaches to business process organization) and gained new knowledge that will allow them to apply their professional skills in production, will improve the level of professional training and make them competitive in the labor market.

Therefore, the concept of lean production is now widely used not only in oil and gas, but also in other sectors of the national economy, because it is necessary to change the approach to production activities of manufacturing enterprises in order to maintain competitiveness.

\section{References:}

1. Інновації. Вилучено 3 https://www.it.ua/knowledge-base/technology-innovation/leanmanufacturing

2. Укргазвидобування.

Вилучено

3

https://www.facebook.com/Ukrgasvydobuvannya/posts/843576999100452/

3. We study Lean together. Energy of Independence: Corporate Edition of JSC "Ukrgasvydobuvannia", (19-20), 63-64. [in English] 


\section{THE METHOD OF THE UNMANNED AERIAL VEHICLES DETECTION IN MULTIRADAR SYSTEM BASED ON SURVEILLANCE RADARS}

RESEARCH GROUP:

Vitaliy Lishchenko

PhD student of Radar Troops Tactic Department Ivan Kozhedub Kharkiv national Air Force University

Ivan Kravchenko

Senior Engineer of Data-Processing Computer Centre Ivan Kozhedub Kharkiv national Air Force University

Lukianchykov Andrii

Research Assistant of Air Force Scientific Center Ivan Kozhedub Kharkiv national Air Force University

Hnyria Volodymyr

Chief Deputy of University in Logistics Ivan Kozhedub Kharkiv national Air Force University

Academic Advisor: Hennadii Khudov Doctor of Technical Sciences, Professor, Chief of Radar Troops Tactic Department Ivan Kozhedub Kharkiv national Air Force University

UKRAINE

It is known that the only effective means of air radar surveillance in airspace is using radars of radar troops. The conduction of air surveillance is accompanied by a decrease in radar visibility of aircrafts in recent years. This is due to an increasing of the number and intensity of the using of small-size unmanned aerial vehicles (UAVs) that can be used throughout the range of altitudes [1].

Under such conditions, a qualitative improvement in the efficiency of air radar surveillance will be possible not so much due to the increase of the radar field, but to a greater extent by complexing the radar information of the individual autonomous existing radars of the fleet of radar surveillance in various systems using modern information technologies and the latest advances radar [2].

We will analyse the possibilities of increasing the efficiency of detection of UAVs by complexing several autonomous surveillance radars into a synchronous coherent multi-radar system.

In order to ensure the possibility of using multi-position methods for detecting and determining the location of UAVs during the integration of autonomous radar surveillance stations in the multi-radar system with a compatible reception, it is necessary to observe the conditions of observation of the aircraft simultaneously for all radars [3]. The number of radars in the multi-radar system is in the work we will restrict it to four. In fig. 1 shows an example of the location and procedure for scanning space with one-type surveillance radars located at a distance $d$, their detection zones at a specified height, and the formation of areas of space with the coefficient of overlapping detection zones $\mathrm{K}$. 


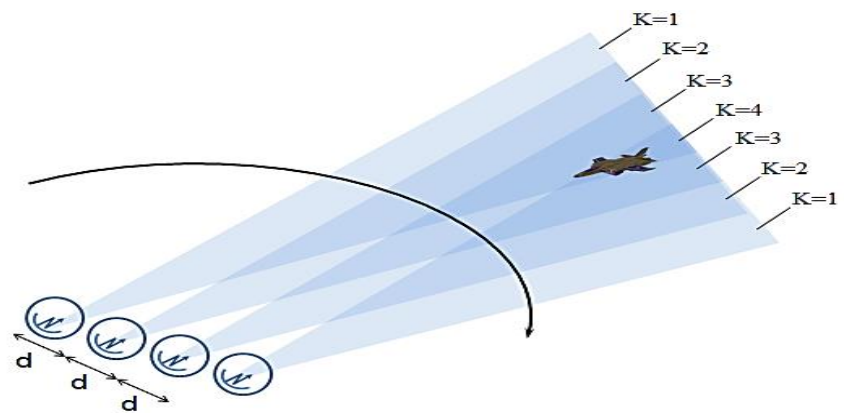

Fig. 1. The spatial location synchronous multi-radar system

From the mathematical modelling of the multiradar system, we can conclude that the complexing of several autonomous radars into a multi-radar system will provide an opportunity to increasing the range of detection of UAVs in certain ranges from 1.4 to 2.7 times depending from the level of implementation of coherence in the system. This is due to an increasing in the energy potential and the using of rarefied antenna array properties.

\title{
References:
}

1. Banasik, M. (2015). How to understand the Hybrid War. Securitologia, (1), 19-34.

2. Hudov, H., Zvonko, A., Kovalevskyi, S., Lishchenko, V. \& Zots, F. (2018). Method for the detection of small-sized air objects by surveillance radars. Eastern-European Journal of Enterprise Technologies, (2, issue 9 (92)), 61-68.

3. Chernyak, V. (1998). Fundamentals of Multisite Radar Systems. Amsterdam, Netherlands: Gordon and Breach Science Publishers.

DOI 10.36074/29.11.2019.v2.11

\section{АВТОМАТИЗАЦИЯ ТЕСТИРОВАНИЯ ПРОГРАММНЫХ СИСТЕМ}

\author{
Денисенко Алексей Александрович \\ разработчик програмного обеспечения \\ ЧП Денисенко \\ УКРАИНА
}

Грамотная организация процесса тестирования программного обеспечения (ПО) является важнейшей составляющей при его разработке и существенно влияет на качество программного продукта $[1,2]$.

Современное ПО часто представляет собой сложные программные системы, состоящие из множества взаимосвязанных элементов (подсистем и модулей). При разработке к таким системам предъявляется большое число различных фрункциональных и нефункциональных требований. 
Поэтому неотъемлемой составляющей процесса тестирования ПО на первой фразе его выполнения является планирование, в ходе которого определяется, в частности: оценка объема и сложности работ; определение необходимых ресурсов (человеческих, программных, аппаратных); определение расписания, сроков и ключевых точек; оценка рисков; распределение обязанностей и ответственности.

В 2011 году А.С. Станкевич в своей диссертации [1] рассмотрел подобные тестирующие системы, их применение в олимпиадах по программированию. Он также подчеркнул значение использования систем автоматического тестирования программ в образовательном процессе.

Олег Годовых в статье [2] рассмотрел типовую структуру систем автоматического тестирования программ, технические особенности её реализации.

Ашлеша Патил в рамках магистерского проекта [3] разработал онлайн приложение Javabrat для автоматического оценивания программ студентов на языке Java и Scala. Автор также отмечает, что автоматическая проверка заданий по программированию имеет свои недостатки, но всё равно подобные системы значительно облегчают процесс проверки.

Известно, что для создания хорошего программного обеспечения (ПО) требуется правильная организация всех этапов процесса разработки, основанная на применении технологических принципов, и, в частности, грамотная организация этапа тестирования как неотъемлемого, наиболее устоявшегося средства современной системы обеспечения качества программного продукта [1].

С целью уменьшения трудоемкости процесса тестирования разрабатываются и применяются различные средства автоматизации [2], обладающие как большим количеством преимуществ, так и рядом недостатков.

Далее представлены результаты исследования проблем автоматизации тестирования ПО на примере разработки прототипа системы для автоматизации тестирования методом, основанным на построении диаграмм причин-следствий.

Диаграммы причинно-следственных связей используются для проектирования тестовых вариантов и обеспечивают формальную запись логических условий и соответствующих действий $[1,3]$. При этом тестируемая программа рассматривается как «черный ящик», поведение которой можно определить только исследованием его входов и выходов.

Метод тестирования ПО, основанный на построении диаграмм причинследствий, включает следующие шаги $[3,4]$ :

1) для тестируемой программы (или отдельного тестируемого модуля) выявляются причины (условия ввода или классы эквивалентности условий ввода) и следствия (действия или условия вывода); каждой причине и следствию присваивается свой идентификатор;

2) разрабатывается граф причинно-следственных связей;

3) граф преобразуется в таблицу решений;

4) столбцы таблицы решений преобразуются в тестовые варианты; 
$100 \bullet$ Problèmes et perspectives d'introduction de la recherche scientifique innovante $\bullet$ Volume 2

5) осуществляется сравнение реальных и ожидаемых результатов работы программы.

Существует множество средств автоматизации тестирования ПО -от небольших программ, решающих частные задачи, до мощных инструментальных средств. Примеры наиболее известных продуктов $[3,5]$ :

1) JUnit - библиотека для модульного тестирования программного обеспечения на языке Java;

2) Selenium - фреймфорк для автоматизации процесса тестирования вебприложений;

3) Katalon Studio - инструмент для автоматизации процесса тестирования веб-приложений, мобильных приложений и веб-сервисов;

4) Watir - инструмент с открытым исходным кодом для автоматизации тестирования веб-приложений, использующий библиотеки Ruby.

Важным недостатком существующих программных продуктов для автоматизации тестирования является то, что многие сложные интеллектуальные задачи (например, разработка тест-кейсов) остаются фактически возложенными на человека - специалиста по тестированию.

В частности, при тестировании ПО-методом, основанным на построении диаграмм причин-следствий, с помощью перечисленных выше средств шаги №1-4 будут выполняться вручную человеком. Требуется автоматизация этих действий для повышения производительности работы специалиста по тестированию.

С целью устранения указанных недостатков разработан прототип системы для автоматизации тестирования ПО на основе построения диаграмм причинследствий. Сформулированы функциональные требования к системе:

1) пользователь задает количество причин и следствий;

2) система создает текстовые поля для заполнения причин и следствий;

3) пользователь создает граф причин-следствий (в прототипе граф строится на основе заполнения экранных форм);

4) система должна отобразить таблицу решений;

5) система показывает пользователю тестовые варианты, по которым будет осуществляться поверка ПО, и на основе этих тестовых вариантов сравнивает реальные и ожидаемые результаты выполнения программы.

Прототип системы является веб-приложением, построенным на основе технологий HTML. CSS, JavaScript в среде разработки NetBeans IDE [6].

Рассмотрим пример автоматизации тестирования ПО с помощью созданного прототипа. Требуется протестировать программу расчета числа аккумуляторных батарей для обеспечения бесперебойного электроснабжения в зависимости от времени и частоты отключения электричества. Для случая, когда частота отключения электричества не более 1 раза в месяц:

1) если среднее время отключения электричества меньше или равно 1 часу, то достаточно К батарей;

2) если среднее время отключения электричества больше 1 часа и меньше 12 часов, то достаточно 1,5К батарей;

3) если среднее время отключения электричества больше или равно 12 часам, то достаточно 2 К батарей. 
Для случая, когда частота отключения электричества больше 1 раза в месяц, полученное значение увеличивается на $50 \%$.

Изначально пользователь вводит количество причин и следствий (рис. 1). После чего нажимает кнопку «Подтвердить количество причин и следствий».

\section{Шаг 1. Определение причин и следствий:}

\section{Примечание:}

Буквой "С" с номером будут обозначаться причины.

Буквой "Е" с номером будут обозначаться следсвия.

Введите кол-во причин (C):

5

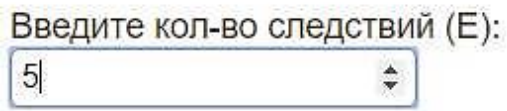

\section{Подтвердить кол-во причин и спедствий}

Рис. 1. Пользователь вводит количество причин и следствий

Далее пользователь заполняет в созданных текстовых полях названия причин (рис. 2) и следствий (рис. 3).

Причины:

\begin{tabular}{|c|c|c|}
\hline № & $\begin{array}{c}\text { Условное обозначение } \\
\text { причины }\end{array}$ & Название причины \\
\hline 1 & С1 & Частота отключения электричества НЕ более 1 раза в месяц \\
\hline 2 & С2 & Частота отключения электричества больше 1 раза в месяц \\
\hline 3 & С3 & Среднее время откпючения электричества меньше или равно часу \\
\hline 4 & С4 & Среднее время отключения электричества больше 1 часа и меньше 12 часов \\
\hline 5 & С5 & Среднее время опключения электричества больше или равно 12 часов \\
\hline
\end{tabular}

Рис. 2. Заполенение информации о причинах

Следствия:

\begin{tabular}{|l|c|l|}
\hline № & $\begin{array}{c}\text { Условное обозначение } \\
\text { следствия }\end{array}$ & Название следствия \\
\hline 1 & E1 & Достаточно К батарей \\
\hline 2 & E2 & Достаточно $1.5^{*} \mathrm{~K}$ батарей (Понснение: это Е1 увеличенное на $\left.50 \%\right)$ \\
\hline 3 & E3 & Достаточно $2^{*} \mathrm{~K}$ батарей \\
\hline 4 & E4 & Достаточно $\left(1.5^{*} \mathrm{~K}\right)+\left(1.5^{*} \mathrm{~K}\right) / 2$ батарей. (Пояснение: это Е2 увеличенное на $\left.50 \%\right)$ \\
\hline 5 & Е5 & Достаточно $\left(2^{*} \mathrm{~K}\right)+\left(2^{*} \mathrm{~K}\right) 2$ батарей. (Пояснение: это Е3 увеличенное на $\left.50 \%\right)$ \\
\hline
\end{tabular}

Рис. 3. Заполенение информации о следствиях 
102 Problèmes et perspectives d'introduction de la recherche scientifique innovante $\bullet$ Volume 2

После чего пользователь устанавливает количество связей (рис. 4) и нажимает на кнопку «Подтвердить количество связей».

\section{Шаг 2. Установка причинно-следственных связей:}

\section{Введите кол-во связей:}

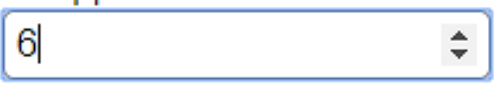

\section{Подтвердить кол-во связей}

Рис. 4. Установка количества связей

Далее пользователь описывает графр причин-следствий с помощью раскрывающихся списков (рис. 5). После установки связей нажимает кнопку «Подтвердить связи».

\begin{tabular}{|c|c|c|c|c|c|c|}
\hline № & \multicolumn{2}{|c|}{ 1-я причина } & \multicolumn{2}{|c|}{ 2-я причина } & \multicolumn{2}{|c|}{ Следствие } \\
\hline 1 & $\mathrm{C} 1$ & $*$ & C3 & 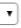 & E1 & $\checkmark$ \\
\hline 2 & C1 & $*$ & C5 & 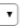 & E3 & V \\
\hline 3 & C1 & $\pi$ & C4 & + & $\mathrm{E} 2$ & $\checkmark$ \\
\hline 4 & $\mathrm{C} 2$ & $*$ & C3 & 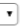 & E2 & 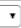 \\
\hline 5 & $\mathrm{C} 2$ & $*$ & C4 & 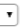 & E4 & V \\
\hline 6 & C2 & $\pi$ & C5 & $T$ & E5 & 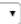 \\
\hline
\end{tabular}

\section{Рис. 5. Создание графра причин-следствий}

Система на основе вышеописанных входных данных генерирует и отображает на экране таблицу решений (рис. 6) и тестовые варианты (рис. 7).

Шаг 3. Создание таблицы решений:

\begin{tabular}{|c|c|c|c|c|c|c|c|}
\hline & & TB1 & TB2 & TB3 & TB4 & TB5 & TB6 \\
\hline \multirow{5}{*}{ Причины } & C1 & 1 & 1 & 1 & 0 & 0 & 0 \\
\hline & $\mathrm{C} 2$ & 0 & 0 & 0 & 1 & 1 & 1 \\
\hline & $\mathrm{C} 3$ & 1 & 0 & 0 & 1 & 0 & 0 \\
\hline & $\mathrm{C} 4$ & 0 & 0 & 1 & 0 & 1 & 0 \\
\hline & C5 & 0 & 1 & 0 & 0 & 0 & 1 \\
\hline \multirow{5}{*}{ Следствия } & E1 & 1 & 0 & 0 & 0 & 0 & 0 \\
\hline & E2 & 0 & 0 & 1 & 1 & 0 & 0 \\
\hline & E3 & 0 & 1 & 0 & 0 & 0 & 0 \\
\hline & E4 & 0 & 0 & 0 & 0 & 1 & 0 \\
\hline & E5 & 0 & 0 & 0 & 0 & 0 & 1 \\
\hline
\end{tabular}

Рис. 6. Таблица решений 
Шаг 4. Тестовые варианты:

\begin{tabular}{|c|c|c|}
\hline № TB & Исходные данные & Ожидаемые результаты \\
\hline TB1 & $\begin{array}{c}\text { Частота отключения электричества НЕ более } 1 \text { раза в месяц } \\
\text { Среднее время опиюючения электричества меньше или равно часу }\end{array}$ & Достаточно К батарей \\
\hline TB2 & $\begin{array}{c}\text { Частота откпючения электричества НЕ более } 1 \text { раза в месяц } \\
\text { Среднее время отключения электричества больше или равно } 12 \text { часов }\end{array}$ & Достаточно 2* К батарей \\
\hline TB3 & $\begin{array}{l}\text { Частота откпючения электричества } \mathrm{HE} \text { более } 1 \text { раза в месяц } \\
\text { Среднее время опслючения электричества больше } 1 \text { часа и меньше } 12 \text { часов }\end{array}$ & Достаточно $1.5^{*}$ К батарей (Пояснение: это Е1 увеличенное на 50 \%) \\
\hline TB4 & $\begin{array}{l}\text { Частота отключения электричества больше } 1 \text { раза в мөсяц } \\
\text { Среднее время оплюючения электричества меньше или равно часу }\end{array}$ & Достаточно 1.5 ^ К батарей (Пояснение: это Е1 увеличенное на 50 \%) \\
\hline TB5 & $\begin{array}{l}\text { Частота отключения электричества больше } 1 \text { раза в месяц } \\
\text { Среднее время откпючения электричества бопьше } 1 \text { часа и меньше } 12 \text { часов }\end{array}$ & Достаточно $\left(1.5^{*} \mathrm{~K}\right)+\left(1.5^{*} \mathrm{~K}\right) / 2$ бятарей. (Пояснение: это Е2 увеличенное на 50 \%) \\
\hline TB6 & $\begin{array}{c}\text { Частота отключения электричества больше } 1 \text { раза в месяц } \\
\text { Среднее время откпючения электричества больше или равно } 12 \text { часов }\end{array}$ & Достаточно (2* К) + (2* К)/2 батарей. (Пояснение: это Е3 увеличенное на $50 \%)$ \\
\hline
\end{tabular}

\section{Рис. 7. Тестовые варианты}

Дальнейшее развитие созданного прототипа:

- добавление возможности визуального построения графа причинследствий (визуальное представление графа для рассмотренной выше задачи показано на рис. 8.);

- применение математических функций для описания следствий;

- автоматизация сравнения реальных и ожидаемых результатов работы программы на основе полученных тестовых вариантов.

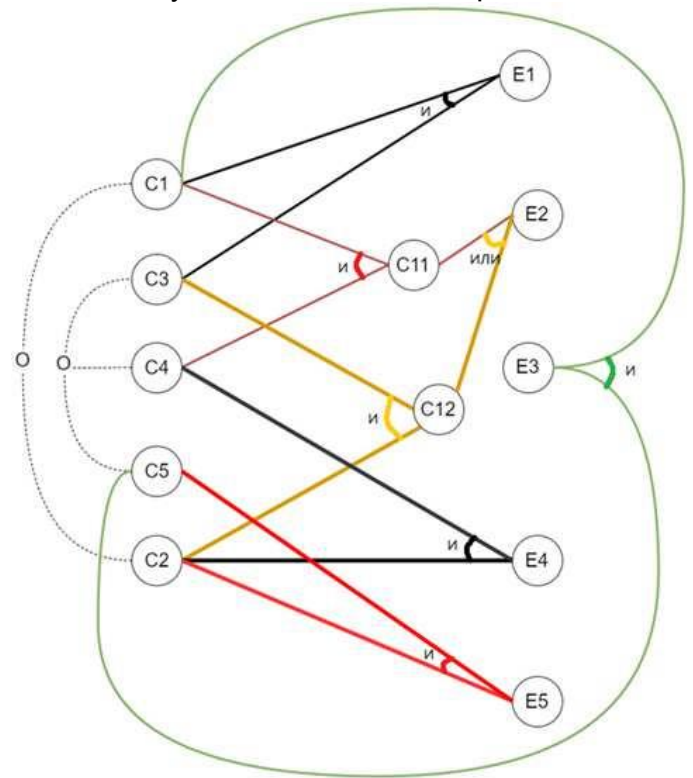

Рис. 8. Граф причин-следствий 
Таким образом, разрабатываемый программный продукт позволит уменьшить временные затраты в ходе тестирования на основе построения диаграмм причин-следствий.

\section{Список используемых источников:}

1. Станкевич, А.С. (2011). Методология и технические решения для проведения олимпиад по информатике и программированию: автореф. дис. ... канд. техн. наук. СПб.

2. Олимпиады по программированию, взгляд из НГУ. Статья 2 - Тестирующая система. Изьято из http://habrahabr.ru/post/63005/ [На русском языке]

3. Patil A. Automatic Grading of Programming Assignments: Master's Projects. Retrieved from $\mathrm{http}: / /$ scholarworks.sjsu.edu/cgi/viewcontent.cgi?article $=1050 \&$ context=etd_projects

4. Куликов, С.С. (2017). Тестирование программного обеспечения. Базовый курс. Минск: Четыре четверти.

5. Полевщиков И. С. (2017). Тестирование программного обеспечения: метод. указания. Пермь: Изд-во Перм. нац. исслед. политехн. университета.

6. Полевщиков, И.С., Кондратович, М.А. \& Селиванова, О.И. (2012). Разработка методического пособия на тему «Способ диаграмм причинследствий» (для студентов и магистрантов направления «Информатика и вычислительная техника»). Педагогика и современность, (2), 79-84.

7. Ton 10 инструментов автоматизации тестирования 2018. Изъято из http://habrahabr.ru/post/342234

8. Web-технологии. Изъято из http://intuit.ru/studies/courses/485/341/info

\section{АВТОМАТИЗОВАНИЙ СИНТЕЗ СТРУКТУР ЗГОРТКОВИХ НЕЙРОННИХ МЕРЕЖ}

Лящинський Павло Борисович

здобувач освітнього рівня «магістр» факультету комп'ютерних інформаційних технологій

Тернопільський національний економічний університет

Лящинський Петро Борисович

здобувач освітнього рівня «магістр» факультету комп'ютерних інформаційних технологій

Тернопільський національний економічний університет

УКРАÏHA

Згорткові нейронні мережі (CNN) $€$ вдалою серединою між біологічно правдоподібними мережами і звичайним багатошаровим перцептроном. На сьогоднішній день кращі результати в розпізнаванні зображень отримують з їх допомогою. В середньому точність розпізнавання таких мереж перевершує звичайні штучні нейронні мережі (ШНМ) на 10-15\%. Згорткові нейронні мережі $(3 \mathrm{HM})$ - це ключова технологія машинного навчання [1].

Більшість сучасних архітектур згорткових нейронних мереж побудовані експертами машинного навчання.

На сьогоднішній день кількість завдань, які можна вирішити за допомогою згорткових нейронних мереж зростає, і спроектувати хорошу мережу стає довгим, повільним та дорогим процесом. 
Типова архітектура згорткової нейронної мережі складається 3 декількох згорткових шарів, шарів субдискретизації та повнозв'язних шарів, які чергуються між собою [2].

Під час проектування архітектури нейронної мережі експерт повинен вибрати кількість шарів кожного типу (згортка, субдискретизація, повнозв'язний шар тощо), послідовність шарів, гіперпараметри для кожного шару тощо.

Нами було розроблено програмний модуль для синтезу структур згорткових нейронних мереж на основі методу Grid Search (повний перебір).

Програма генерує структури згорткових нейронних мереж для всіх комбінацій, після чого, кожна з отриманих мереж навчається на цитологічних зображеннях.

Для кожної моделі виводиться точність та ROC-крива (рис. 1). Після завершення навчання всіх моделей, користувачу виводиться комбінація параметрів, що показали найкращі результати.

\section{Model 1}

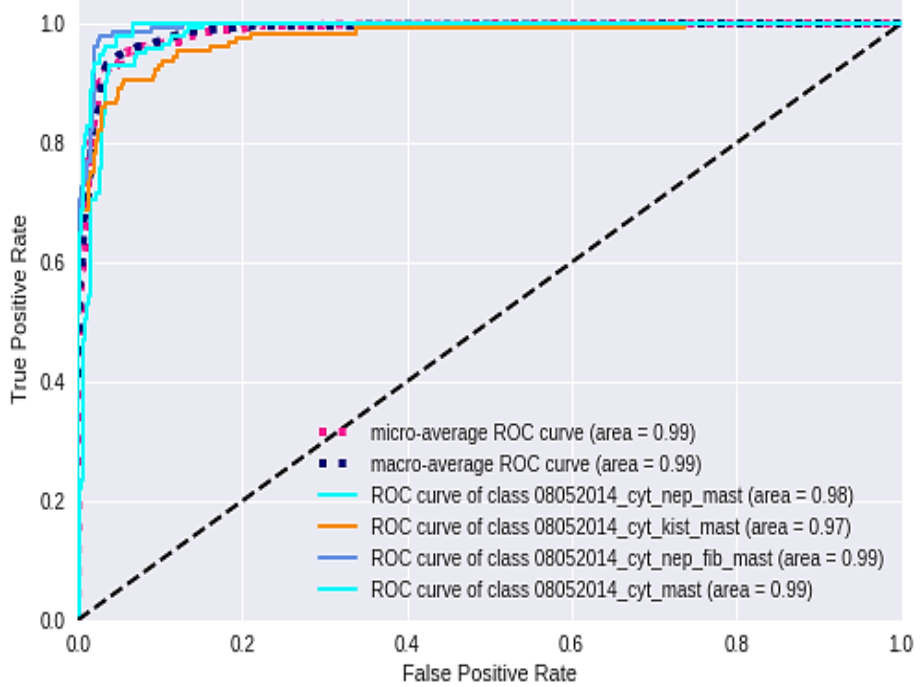

Рис 1. ROC-крива базової моделі

Точність базової моделі становить $85 \%$. Точність моделі, згенерованої розробленим алгоритмом становить $96 \%$.

Висновки. Програмно реалізовано автоматизований синтез структур згорткових нейронних мереж, що дало змогу синтезувати структури нейронних мереж з мінімальним втручанням користувача.

\section{Список використаних джерел:}

1. Elsken, T., Metzen, J. H. \& Hutter, H. F. (2018). Multi-objective Architecture Search for CNNs. ArXiv. Вилучено 3 https://arxiv.org/pdf/1804.09081v1.pdf.

2. Elsken, T., Metzen, J. H. \& Hutter, H. F. (2019). Neural Architecture Search: A Survey. Journal of Machine Learning Research, (20), 1-21. 


\title{
АНАЛІЗ СТРУКТУРИ ІНФОРМАЦІЙНОЇ СИСТЕМ ПОШУКУ ТА ВИЛУЧЕННЯ ФАКТІВ 3 IНТЕРНЕТ-ВІДГУКІВ ПРО ТОВАР
}

\author{
НАУКОВО-ДОСЛІДНА ГРУПА:
}

Бабкова Надія Вікторівна

канд. техн. наук, доцент кафедри інтелектуальних комп'ютерних систем Національний технічний університет «Харківський політехнічний інститут»

Яковенко Карина Валеріївна

асистент кафедри програмної інженерії та інформаційних технологій управління Національний технічний університет «Харківський політехнічний інститут»

Рогинський Олексій Вячеславович

здобувач вищої освіти факультету соціально-гуманітарних технологій Національний технічний університет "Харківський політехнічний інститут»

Хазієв Арсеній Вадимович

здобувач вищої освіти фракультету соціально-гуманітарних технологій Національний технічний університет «Харківський політехнічний інститут»

УKPAÏHA

На даний час широкого поширення отримала практика написання відгуків про отриманий товар або послугу на сайтах, які присвячені е-комерції. Розглянемо можливості використання інформаційних технологій для виявлення фрактів з такого виду текстів. По-перше, розглянемо існуючу класифікація життєвого циклу інформаційної системи (IC) - сукупності стадій і етапів, які система проходить у своєму розвитку від моменту прийняття рішення про ії створення до моменту припинення функціонування.

Існує велика кількість стандартів та методик, які регламентують як життєвий цикл IC у цілому, так і окремі його етапи [1]. Будемо вважати, що життєвий цикл IC складається з таких етапів:

1. Виявлення й аналіз вимог - системний аналіз. Здійснюються дослідження й аналіз існуючих систем, виявляються вимоги до IC, формуються техніко-економічне обґрунтування і технічне завдання на розробку IC.

2. Проектування (технічне і логічне). Відповідно до вимог фоормуються переліки функцій системи (функціональна архітектура) і підсистем (системна архітектура), оформляється технічний проект IC.

3. Реалізація (робоче і фрізичне проектування, кодування). Розробка та налаштування програм, формування і наповнення баз даних, складання робочих інструкцій для персоналу, оформлення робочого проекту.

4. Упровадження (дослідна експлуатація). Комплексне налаштування підсистем IC, навчання персоналу, поетапне впровадження IC в експлуатацію по підрозділах організації, офрормлення нормативних документів про впровадження в експлуатацію IC. 
5. Експлуатація IC (супровід, модернізація). Збирання рекламацій і статистики функціонування IC, виправлення помилок і недоробок, виявлення вимог до модернізації IC і її виконання (повторення етапів 2-5).На всіх етапах життєвого циклу IC як розробникам, так і персоналу потрібно вирішувати задачі інформаційного пошуку: пошук джерел знань і виявлення знань предметної області (ПО) [2] (етапи 1-2); виявлення інформації для фрормування і наповнення баз даних IC (етап 3); пошук і аналіз змін нормативно-правового й інформаційного забезпечення IC (етапи 4-5) тощо. Існує велика кількість методів інформаційного пошуку, аналізу інформації, виявлення даних i знань [3; 4].

Розроблені інструментальні засоби, у тому числі інформаційно-пошукові системи Інтернету, що можуть бути використані для вирішення окремих задач життєвого циклу IC [5; 6]. Але на сьогодні відсутні інструментальні засоби і методики, які б дали змогу вирішувати ці задачі комплексно, на всіх етапах життєвого циклу IC, тобто склалася ситуація, коли в Інтернеті і корпоративних мережах міститься величезна кількість інфрормації у вигляді текстів на природній мові.

Отже, $€$ можливість отримувати спеціалізовані видання і книги в електронному вигляді, але за існуючих інструментальних засобів обробки таких документів доводиться витрачати багато часу і зусиль для того, щоб здобути знання, необхідні для вирішення практичних завдань. Парадоксальність ситуації полягає в тому, що чим більші обсяги інформації в електронному вигляді отримує людина, тим більш недоступними стають знання. За відсутності адекватних і ефеетивних засобів обробки текстів на природній мові користувач змушений прочитувати великі масиви текстових документів, що досить складно. Отже, виникає необхідність скорочувати масив документів за рахунок виключення малоінформативних, повторюваних, неактуальних текстів. При цьому зростає ризик відбраковування корисних інформативних або навіть ключових документів.

Для вирішення цієї проблеми потрібно мати технології й інструменти виявлення даних і знань з масивів текстів на природній мові. Специфрічним для України є те, що джерела даних і знань можуть бути подані як українською, так і російською мовами. У зв'язку з цим необхідно відмітити декілька фрактів, які були нами виявлені, зокрема:

- інструментальні засоби обробки текстових документів, складених українською мовою, практично відсутні, за винятком інформаційно-пошукових систем Інтернету;

- публікацій в Інтернеті стосовно комп'ютерної обробки текстів українською мовою вкрай мало;

- україномовні ресурси в електронному вигляді, у вільному доступі (словники, корпуси текстів тощо) практично відсутні. Такий стан речей можна пояснити як відсутністю вказаних засобів і ресурсів, так і слабким поданням їх в Інтернеті.

На основі аналізу потреб в інформаційному забезпеченні етапів життєвого циклу IC та існуючих підходів до пошуку і аналізу інформації запропоновано найбільш оптимальну структуру системи пошуку інформації та виявлення знань з інформаційних ресурсів (рис.1). 


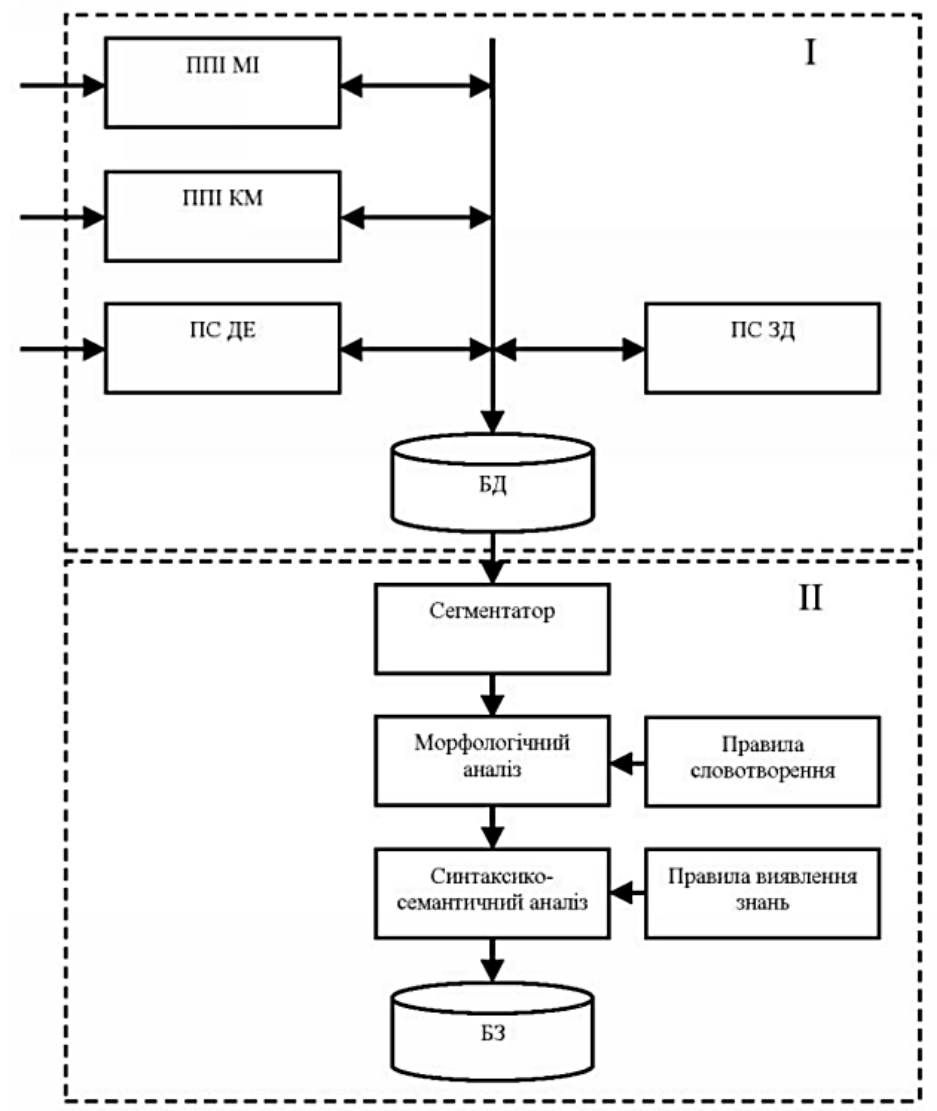

Рис 1. Актуальна структура системи пошуку та вилучення фактів 3 інтернет-відгуків

Система складається з двох основних частин: пошукової машини (I) та системи аналізу текстів і виявлення знань (II). Пошукова машина (ПМ) складається з наступних підсистем: пошуку інформації в Інтернеті (ППІ МІ); пошуку інформації в корпоративній мережі (ППІ КМ); спостереження за діями експерта (ПС ДЕ); спостереження за змінами документів предметної області (ПС ЗД); база даних (БД).

Підсистема аналізу текстів і виявлення знань, складається 3 таких підсистем: сегментатор [6]; морфологічний аналізатор; синтаксикосемантичний аналізатор; база знань (БЗ).

Основною відмінністю системи, що пропонується, від аналогічних [5] $є$ наявність підсистеми спостереження за діями експерта. Це дає можливість отримувати первинний набір текстів предметної області, необхідний для налаштування і навчання системи, без чого ії робота буде неможлива. Слабким місцем при розробці і впровадженні IC є взаємодія між аналітиками й 
експертами, але наявність підсистеми спостереження дозволить поліпшити їхню взаємодію.

Згідно 3 класифікацією система, що розробляється, належить до автоматизованих систем управління знаннями. У перспективі намічається отримати базу знань предметної області, яка може бути використана як на етапі розробки IC, так і на етапі експлуатації як складова частина IC; скоротити час проведення етапу аналізу предметної області, у тому числі і за рахунок скорочення часу спілкування між основними учасниками процесу; підвищити якість розробки і функціонування IC за рахунок більш точного виявлення вимог до системи; накопичувати знання і дані під час роботи над різними проектами.

\section{Список використаних джерел:}

1. Кочуєва, 3. А. (2014) Методи і моделі інтелектуальної обробки інформаційних об'єктів у сучасних бібліотечних системах (автореф. дис. ... канд. техн. наук). Національний технічний університет "Харківський політехнічний інститут, Харків, Україна.

2. Коханова, І. О. (2014). Проблеми та похибки методів автоматизованого реферування документів. Вісник Книжкової палати, (9), 31-32.

3. Снитюк, В. Е. \& Юрченко, К. Н. (2013) Интеллектуальное управление оцениванием знаний. Черкассы.

4. Даревич, Р. Р. (2005) Підвищення ефективності інтелектуального аналізу тесту шляхом зважування понять моделі онтології. Штучний інтелект, (3), 571-577.

5. Бармак, О. В. \& Мазурець О. В. (2015) Інформаційна технологія автоматизованого визначення термінів у навчальних матеріалах. Вимірювальна та обчислювальна техніка в технологічних процесах, (2), 94-102

6. Автоматическая генерация осмысленных уникальных текстов. (2015). Вилучено $з$ https://habr.com/company/meanotek/blog/259355/

\section{БІОЛОГІЧНО ЦІННІСТЬ ШВИДКОЗАМОРОЖЕНОГО ДЕСЕРТУ ФУНКЦІОНАЛЬНОГО ПРИЗНАЧЕННЯ 3 ВИКОРИСТАННЯМ ХУРМИ}

Заболотна Альона Вадимівна канд. с.-г. наук, ст. викладач кафедри технологій харчових продуктів Уманський національний університет садівництва

Заболотний Олександр Іванович канд. с.-г. наук, доцент кафедри біології Уманський національний університет садівництва

Пиркало Віталій Васильович викладач кафедри технологій харчових продуктів Уманський національний університет садівництва УKPÄ̈HA

Характерною ознакою сучасного ринку плодоовочевих товарів $\epsilon$ збільшення у асортиментній структурі частки продуктів з високим ступенем їх готовності до споживання, у тому числі швидкозаморожених напівфабрикатів та готових страв. 
Позитивна динаміка виробництва та споживання швидкозаморожених плодоовочевих продуктів у зарубіжних країнах (40 - 50 кг на одну особу) підтверджує відповідність вищезазначених продуктів потребам споживачів та сучасним концепціям харчування. На відміну від світових тенденцій, в Україні щорічне споживання швидкозамороженої плодоовочевої продукції на одну особу становить лише 0,5 кг. На ринку України вищезазначені продукти на $70 \%$ представлені продукцією зарубіжних виробників, за рахунок якої переважно задовольняється попит споживачів. Це спричинено неузгодженістю інтересів вітчизняних виробників та споживачів щодо асортименту, якості та ціни на швидкозаморожені плоди і овочі. Значне відставання споживної вартості вітчизняної продукції від цінової зумовлено порушенням цілісності холодильного ланцюга, відсутністю критеріїв ідентифікації якості продукції на етапах її виробництва, зберігання, транспортування та реалізації.

Встановлено, що в Україні та країнах зарубіжжя наукові дослідження, спрямовані на формування і стабілізацію якості швидкозаморожених плодів і овочів, проводяться за значною кількістю напрямів, основними з яких $є$ сортопридатність рослинної сировини до заморожування, способи попередньої обробки плодів і овочів перед заморожуванням, способи заморожування, пакування та розморожування продукції. Водночас слід зазначити, що комплексні дослідження формування асортименту й збереження споживних властивостей швидкозаморожених плодоовочевих продуктів з урахуванням потреб споживачів, що забезпечує узгодженість попиту та пропозиції на ринку швидкозаморожених плодоовочевих продуктів, у рамках одного експерименту не проводились.

Метою і завданням дослідження є: розширення асортименту десертних страв функціонального призначення. Обєкти дослідження: гарбуз сорту Арабатський, хурма сорту Шарон, яблука сорту Сніговий кальвіль. Предметом дослідження $є$ зміни фрізико-хімічних показників сировини та готового продукту; безпечність готових видів продукту. Методи досліджень. Стандартні методи дослідження фрізико-хімічних та органолептичних показників.

Новизна. Вперше розроблено та досліджено якісні показники десертної страви функціонального призначення на основі гарбуза з додаванням.

Одним з найефективніших способів перероблення плодів і овочів, який забезпечує максимальне збереження споживних властивостей, $€$ заморожування [1]. Швидкозаморожені плоди та овочі, порівняно 3 продуктами, отриманими іншими способами консервування, мають низку переваг. Високий рівень збереження вихідних властивостей сировини під час заморожування, має суттєве значення для виробництва продуктів дитячого та дієтичного харчування. В заморожених плодах і овочах краще зберігаються смакові та споживні властивості. Так, втрати вітаміну С при заморожуванні плодів складають 20\%, при виробництві конфітюру - 33, компоту - 34, мармеладу - 58, сиропів - 75, сушінні - 83\% [2].

Недостатня забезпеченість вітамінами, мінеральними речовинами та іншими біологічно активними речовинами знижує працездатність людини, опірність до захворювань, посилює негативну дію шкідливих умов зовнішнього середовища. Такі різноманітні прояви дефіциту біологічно активних речовин пов'язані насамперед з порушенням специфічних функцій вітамінів, що беруть участь у біохімічних реакціях. 
За хімічним складом гарбуз - цінний овоч для дитячого та дієтичного харчування. Вміст каротину у гарбузі вищий, ніж в інших овочах (від 3.2 до 17.3 мг/100 г). Основну масу його сухих речовин становлять вуглеводи, крохмаль у деяких сортах майже відсутній, а в інших досягає 5 вміст пектинових речовин становить 2.6-3.9\%; клітковини (0.5-1.3\%).

Яблука $€$ не тільки одним 3 найбільш затребуваних фрруктів серед споживачів України, але і цінна технологічна сировина для отримання ряду продуктів харчування. Не дивлячись на невисоку енергетичну цінність, вони $€$ одним з основних джерел вітамінів, мінеральних солей, органічних речовин і, в значній мірі, легко засвоюваних вуглеводів. Яблука містять, \%: цукрів - 8-15, органічних кислот - 0,2-1,7, пектинових речовин - 0,5-1,2, дубильних - 0,0161,0, мінеральних - 0,5, вітаміну C - 4,2-21,1 мг; є також вітаміни В1, B2, B6, PP, Е, каротин.

Хурма відноситься до дієтичних продуктів, які містять зовсім мало калорій, але чудово вгамовують голод, незамінна при розладі травлення завдяки наявності пектину. Принциповою відмінністю запропонованих продуктів $€$ використання в рецептурах сировини з високим вмістом природних антиоксидантів - вітаміну C, $\beta$-каротину, поліфенольних речовин, раціональне поєднання яких гарантує повноцінне забезпечення поживними і біологічно цінними речовинами всіх життєво важливих систем організму, включаючи імунну.

Дослідження проводили згідно методик, що рекомендовані ДСТУ.

В сировині та готовому продукті визначались наступні показники:

- вміст сухих розчинних речовин визначали рефрактометричним методом за ДСТУ ISO 2173:2007[3];

- вміст титрованих кислот (в перерахунку на яблучну кислоту) - за ДСТУ 4957:2008[4];

- вміст цукрів - фероціанідним методом за ДСТУ 4954:2008 [5];

- вміст аскорбінової кислоти - йодометричним методом [6].

Дослідженнями було встановлено, що дана сировина є біологічно цінним матеріалом для переробної галузі та містить достатньо біологічно активних речовин для створення з неї продуктів функціонального призначення (табл. 1).

Таблиця 1

Хімічний склад вихідної сировини для приготування десерту

\begin{tabular}{|c|c|c|c|c|c|}
\hline Сировина & $\begin{array}{c}\text { Сухі розчинні } \\
\text { речовини, } \%\end{array}$ & Цукри, \% & $\begin{array}{c}\text { Титрована } \\
\text { кислотність, \% }\end{array}$ & $\begin{array}{c}\beta \text {-каротин } \\
\text { мг/100г }\end{array}$ & $\begin{array}{c}\text { Аскорбінова } \\
\text { кислота, мг/100 г }\end{array}$ \\
\hline Хурма сорту Шарон & 6,5 & 14,9 & 0,14 & 1,2 & 15 \\
\hline Гарбуз сорту Арабатський & 9,6 & 6,6 & 0,3 & 22,5 & 7,5 \\
\hline $\begin{array}{c}\text { Яблука сорту Сніговий } \\
\text { кальвіль }\end{array}$ & 12,0 & 9,0 & 0,7 & 0,03 & 13 \\
\hline
\end{tabular}

На основі рецептури «Десерт гарбузово-яблучний» нами розроблено новий вид десерту функціонального призначення - «Десерт з гарбуза та хурми». На наш погляд, в рецептурі страви замість яблук доцільно використовувати хурму. Для запобігання серцево-судинних захворювань регулярне вживання хурми більш корисне, ніж вживання яблук. У складі хурми високий відсоток харчових волокон, мінералів і поліфенолів, особливо дубильних речовин, які $\epsilon$ потужними антиоксидантами. Перераховані речовини відіграють важливу роль 
в боротьбі 3 атеросклерозом як основною причиною серцево-судинних захворювань, інфарктів і інсультів. Це навело діячів науки на думку зробити порівняльний аналіз двох корисних для серця фруктів. У хурмі міститься в два рази більше харчових волокон, ніж у яблуках, більше антиоксидантів фенольної природи, калію, магнію, кальцію, заліза і марганцю.

Так, згідно наших досліджень, запропонований десерт має більший вміст біологічно активних речовин, що перевищує десерт взятий за основу в 1,5-2 рази. Також в ньому збільшується вміст сухих розчинних речовин. А за рахунок заміни цукру на натуральний цукрозамінник значно знижується калорійність страви.

Отже використання плодів хурми сприяє збагаченню десертної страви макро-, мікронутрієнтами та біологічно активними речовинами, а заморожування дозволяє зберегти їх протягом тривалого часу.

\section{Список використаних джерел:}

1. Птичкин, И.И. \& Птичкина, Н.М. (2012). Пищевые полисахариды: структурные уровни и функциональность. Саратов: ГУП «Типография № $6 », 96$ с.

2. Барская, И.Э., Ладыжанский, И.А. \& Федоренко, В.Т. (1989). Эфффектиивность производства быстрозамороженной плодоовощной продукции. М.: Агропромиздат.

3. Продукти з фрруктів та овочів. Визначення розчинних сухих речовин рефрактометричним методом: ДСTУ ISO 2173:2007 (ISO 2173:2003, IDT). (2008). K. : Міністерство аграрної політики України.

4. Продукти переробляння фрруктів та овочів. Методи визначення титрованої кислотності: ДСТУ 4957:2008. (2008). К.: Міністерство аграрної політики України, 2009.

5. Продукти переробляння фруктів та овочів. Методи визначення иукрів: ДСТУ 4954:2008. (2009). К: Міністерство аграрної політики України, 2009.

6. Фрукти, овочі та продукти їх перероблення. Визначення вмісту аскорбінової кислоти. Частина 1. Контрольний метод: ДСТУ 6557-1:2015 (ISO 6557-1:1986, IDT) (2016). К.: Міністерство аграрної політики України, 2016. 16 с

\section{ВАЖНОСТЬ СИСТЕМЫ МЕНЕДЖМЕНТА КАЧЕСТВА И ЕЕ ВЛИЯНИЕ НА КАЧЕСТВО ПРОДУКЦИИ НА ПРЕДПРИЯТИЯХ РЕСПУБЛИКИ КАЗАХСТАН}

Амренова Анель Бауыржанкызы
магистрант транспортно-энергетического факультета,
Евразийский национальный университет

Тайманова Гульнара Кабжановна канд. техн. наук, доцент

Евразийский национальный университет

РЕСПУБЛИКА КАЗАХСТАН

В условиях активизации деятельности по внедрению международных стандартов ИСО 9000 версии 2015 года особую актуальность приобретает проблема улучшения системы менеджмента качества (СМК) в организациях. 
При этом важно выявить, собрать и проанализировать соответствующие данные для подтверждения результативности СМК.

Качество продукции оценивают количественным определением показателей качества продукции. Чтобы сделать вывод о качестве продукции, необходимо сравнить показатели ее качества с базовыми. Относительная характеристика качества продукции, основанная на сравнении группы показателей ее качества соответствующей группой базовых показателей, называется уровнем качества продукции [1,2].

Чтобы определить важность СМК и ее эффеективность на предприятиях, приведем в качестве примера завод по ремонту горно-транспортного оборудования ТОО «Курылысмет». Основная задача завода - обеспечение предприятий корпорации запасными частями и оборудованием машиностроительного назначения.

На предприятии ТОО «Курылысмет» внедрена и поддерживается в рабочем состоянии система менеджмента качества с 2012 в соответствии с требованиями стандартам ИСО серии 9000. Основной целью внедрения СМК было постоянное улучшение, повышение результативности предприятия. В 2018 году был проведен внутренний аудит на предприятии ТОО «Курылысмет». В результате которого аудиторами зарегистрировано 64 несоответствия (таблица 1) и остальные замечания носили рекомендательный характер.

Таблица 1

Количество несоответствий согласно пунктам стандарта CT PK ISO 9001-2016

\begin{tabular}{|l|c|}
\hline Пункты стандарта СТ РК ISO 9001-2016 & Количество несоответствий \\
\hline 5.2 Политика & 3 \\
\hline 6.3 Планирование изменений & 4 \\
\hline $\begin{array}{l}\text { ж.1 Планирование и управление деятельностью на стадиях } \\
\text { жизенного цикла продукции и услуг }\end{array}$ & 5 \\
\hline 8.3 Проектирование и разработка продукции и услуг & 5 \\
\hline $\begin{array}{l}\text { 8.4 Управление процессами, продукцией и услугами, } \\
\text { поставщиками }\end{array}$ & 7 \\
\hline 8.5 Производство продукции и предоставление услуг & 21 \\
\hline 9.1 Мониторинг, измерение, анализ и оценка & 7 \\
\hline 9.2 Внутренний аудит & 11 \\
\hline 9.3 Анализ со стороны руководства & 1 \\
\hline Итого: & 64 \\
\hline
\end{tabular}

взято с [авторская разработка]

По итогам внутреннего аудита наибольшее количество несоответствий имеет процесс 8.5 «Производство продукции и предоставление услуг». В связи с этим были проведены мероприятия по их устранению, а также рассмотрены все риски возможного повторного появления. После проведения внутреннего аудита процент вероятности брака упал на $3 \%$, что в свою очередь повлияло на рост продаж всего предприятия.

Система менеджмента качества на предприятиях Республики Казахстан дает возможность увеличить конкурентные преимущества предприятия, доказать заинтересованным сторонам высокое качество продукции, а также экологическую и промышленную безопасность производств [3]. 
114 - Problèmes et perspectives d'introduction de la recherche scientifique innovante $\bullet$ Volume 2

\title{
Список используемых источников:
}

1. Крылова, Г. Д. (2006). Основы стандартизации, сертификации, метрологии. (3-е изд.). М.: ЮНИТИ.

2. Жунусова, А. Ш., Гейдан, И.А. (2007). Технология разработки стандартов и нормативной документации. Караганда: КарГТУ.

3. Кохтев, А.А. (2011). Основы стандартизации. (2-е изд.) М.: Высшая школа.

DOI 10.36074/29.11.2019.v2.13

\section{ВИЗНАЧЕННЯ ФІЗИЧНИХ ХАРАКТЕРИСТИК ОПЕРАЦІЇ ОБРОБЛЕННЯ СВЕРДЛІННЯМ}

\author{
Біланенко Віктор Григорович \\ канд. техн. наук, доцент кафедри технології машинобудування \\ Національний технічний університет України \\ «Київський політехнічний інститут ім. Ігоря Сікорського» \\ УКРӒ̈HA
}

Оброблення різанням сучасних конструкційних матеріалів включає універсальні методи формоутворення робочих поверхонь деталей машин, які за обсягом практичного застосування складають біля 85\% всіх процесів розмірного оброблення, що використовуються в машинобудуванні і за технічними прогнозами спеціалістів на протязі найближчих десятиліть будуть залишатись основними ефективними методами виготовлення деталей машин [1].

Важливими конструктивними елементами деталей машин є отвори, які в залежності від службового призначення виробу та вимог до їх характеристик якості можуть використовуватись для забезпечення таких технологічних завдань:

- виконувати функцію основних конструкторських баз, які визначають положення деталі в складальній одиниці або вузлу;

- допоміжних конструкторських баз, які визначають задане положення деталей, які приєднуються, наприклад головні отвори корпусних деталей, які використовуються для заданого просторового розміщення валів разом 3 підшипниковими вузлами, робочих поверхонь циліндрів гідравлічних та пневматичних циліндрів та інше:

- кріпильних поверхонь, які можуть бути наскрізними для розміщення болтів та з нарізами для загвинчування шпильок, гвинтів та інше;

- вільних поверхонь, які виготовляються у виробах великих габаритних розмірів переважно для зменшення їх загальної маси без втрати характеристик міцності та жорсткості конструкції виробу або забезпечення доступу до елементів конструкції, які використовуються для виконання налагоджувальних та регулювальних робіт.

У відповідності до службового призначення конструкції виробу визначаються вимоги до характеристик якості виготовлення таких отворів. Узагальнені вимоги 
до точності розмірів отворів, які виготовляються в деталях машинобудування практично складають квалітети (IT5-IT14), вимоги до параметрів шорсткості обробних отворів в діапазоні $R_{a}=(0,16-20)$ мкм.

Для отворів, які за службовим призначенням повинні забезпечувати необхідну точність просторового розташування деталей, що приєднуються, важливою вимогою $€$ точність їх просторового розташування, тому при конструюванні деталей машин з урахуванням їх службового призначення, необхідно встановлювати комплексні вимоги до точності координатних розмірів, що визначають точність їх просторового розташування, точності розмірів отвору, точності форми отвору у поперечному та поздовжньому перерізах та визначати узгоджені з точністю отворів вимоги до параметрів шорсткості обробних поверхонь.

Проектування технологічних операцій оброблення отворів передбачає послідовне вирішення типових технологічних завдань:

- у відповідності до заданих креслеником характеристик якості оброблення отвору визначити типові послідовності оброблення, які в підсумку їх послідовного виконання повинні їх забезпечити;

- визначити інструментальні матеріали, які можуть забезпечувати ефективне оброблення заданого конструкційного матеріалу;

- визначити конструкції різальних інструментів та геометричні параметри різальної частини;

- визначити раціональні, а краще оптимальні режими різання, які повинні забезпечити найбільшу продуктивність виконання кожного технологічного переходу.

Оброблення отворів в суцільному матеріалі передбачає обов'язкове застосування першого технологічного переходу свердління, для реалізації якого використовують свердла різноманітних конструкцій, кінематична схема оброблення якими передбачає наявність головного обертального руху різання та руху подачі, вектор швидкості якої співпадає з віссю свердла. Сучасні інструментальні фірми, наприклад німецька фірма GUHRING, виготовляють спіральні свердла в діапазоні розмірів (0,5-80)мм, що практично може забезпечити оброблення свердлінням та розсвердлюванням отворів таких розмірів. Фірма Walter та Walter Titex пропонують повний асортимент різальних інструментів для оброблення отворів в діапазоні діаметрів (0,05-100)мм.

Необхідно приймати до уваги, що осьові різальні інструменти є розмірними інструментами, що обумовлює обмеженість їх застосування, а розширення технологічних можливостей сучасних систем управління металорізальними верстатами з ЧПУ створює нові технологічні прийоми оброблення отворів фрезеруванням 3 круговою інтерполяцією. Оброблення отворів фрезеруванням $€$ більш універсальним, а часто і більш продуктивним, оскільки фрезу одного розміру можна використовувати для оброблення отворів в широкому діапазоні зміни їх розмірів, особливо в діапазоні розмірів $\varnothing D \geq 30 \mathrm{Mm}$.

Оброблення свердління отворів в суцільному матеріалі має просту кінематичну схему, яка включає обертальний головний рух різання та поступальний рух подачі, але процес різання характеризується складними фрізичними та технологічними особливостями, які значною мірою обумовлені конструктивними особливостями різального інструменту. Для виготовлення 
різальної частини сучасних конструкцій свердел використовують швидкорізальні сталі (HSS) та металокерамічні тверді сплави HW та HC.

Конструкції свердел значною мірою залежать від розмірів отворів, які необхідно обробляти. Для оброблення отворів розмірами $\varnothing \leq 15 \mathrm{mм}$ використовуються спіральні свердла традиційних конструкцій, які виготовляються з швидкорізальних сталей та суцільно твердосплавні свердла 3 металокерамічних твердих сплавів. Додатково, для підвищення роботоздатності різальної частини свердла в заданих умовах оброблення, використовують градієнтні зносостійкі покриви на базі TiC, TiN, TiCN, Al $2 \mathrm{O}_{3}$ та комбінації на їх основі, що забезпечує підвищення продуктивності оброблення та стійкості різальної частини інструменту (рис.1).

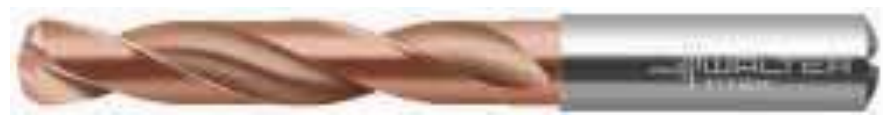

\section{Рис.1. Конструкція спірального суцільно твердосплавного свердла зі зносостійким покривом робочої частини свердла}

Важливою вимогою до технологічних операцій оброблення різанням є зменшення витрат на різальний інструмент, що при обробленні отворів $\varnothing D \geq 12$ мм досягається за рахунок використання нових конструкцій свердел, в яких 3 інструментальних матеріалів виготовляють тільки змінну різальну частину, яку за рахунок вибору фрізико-механічних характеристик інструментального матеріалу та спеціальних форм загострювання адаптують для ефективного оброблення певних груп оброблюваних матеріалів. В таких конструкціях різальна частина виготовляється 3 металокерамічних твердих сплавів, а закріпна частина 3 канавками для видалення стружки 3 інструментальної конструкційної сталі (рис.2).

Конструкції таких свердел мають більш високу жорсткість, що обумовлює підвищення точності оброблення, а твердосплавна різальна частина забезпечує підвищення продуктивності оброблення. При втраті роботоздатності різальної частини свердла, твердосплавна вставка досить просто змінюється на нову. В конструкціях таких свердел заміна здійснюється безпосередньо в закріпному патроні. Вставка затискається в гнізді стрижня свердла за допомогою спеціального байонетного кріплення. Точність установки вставок не потребує будь-яких допоміжних дій для підналагодження положення різальних кромок свердла після заміни вставки. Корпус свердла дозволяє установку змінної різальної частини в певному діапазоні зміни розмірів, що за традиційних конструкцій свердел є неможливим.

Додатково така конструкція різальної вставки зменшує інтенсивність зношування корпусу свердла стружкою, яка видаляється з зони різання.

Для оброблення отворів $\varnothing D \geq 12$ мм найбільш досконалою конструкцією свердел $є$ свердла, різальна частина яких утворена змінними багатогранними пластинами (рис.3). 

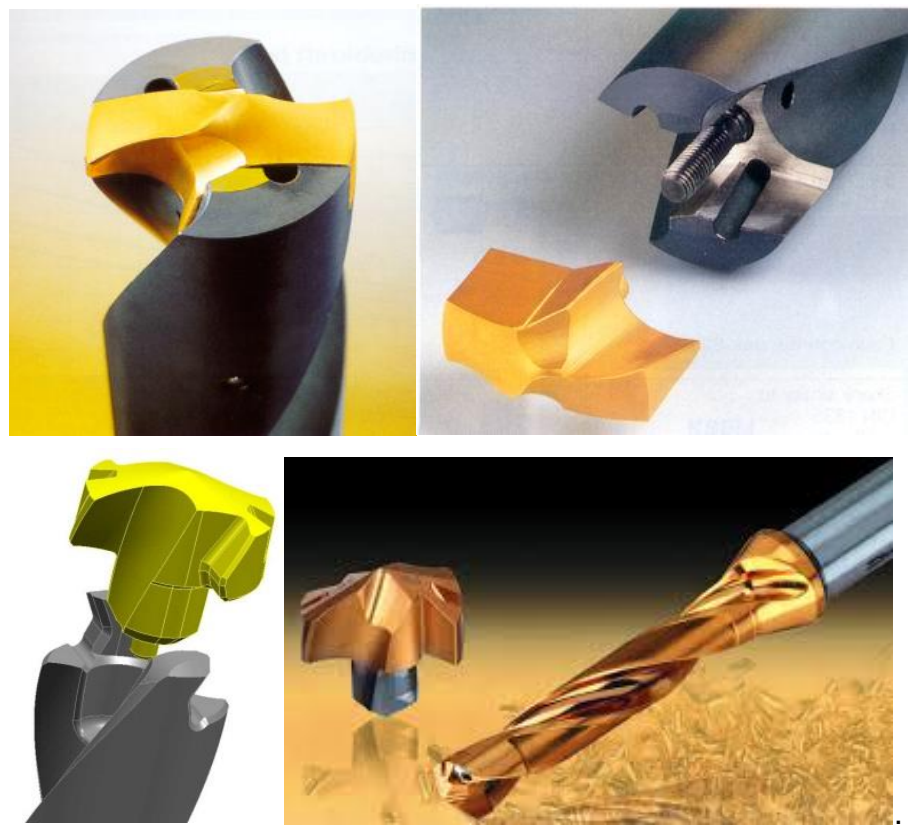

Рис. 2. Конструкції свердел зі змінними різальними частинами

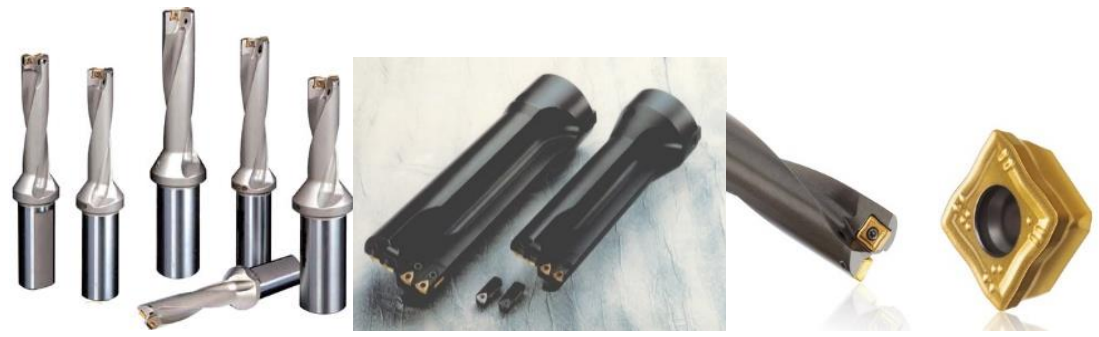

Рис.3. Конструкція свердла зі змінними багатогранними пластинами

Проектування технологічних операцій оброблення отворів спіральними свердлами потребує урахування особливостей геометричних параметрів їх різальної частини, які мають значний вплив на фрізичні умови процесу оброблення. Важливою особливістю конструкції спірального свердла $\epsilon$ необхідність забезпечення симетричності розміщення різальних кромок відносно осі свердла, що в підсумку повинно забезпечувати врівноваження радіальних складових сили різання $P_{y}$, які діють на парні різальні кромки та прямолінійність осі обробленого отвору. 
Геометричні параметри різальної частини свердла, а саме передній кут $\gamma$, задній кут $\alpha$ та кут підйому гвинтової канавки $\omega €$ змінними впродовж головних різальних кромок, що обумовлює зміну фізичних умов процесу оброблення на різних ділянках різальних кромок. Так передній кут різальної кромки в головній січній площині для точки різальної кромки, яка розглядається визначається за формулою:

$$
\tan \gamma_{i}=\frac{r_{i}}{r} \cdot \frac{\tan \omega}{\sin \varphi}
$$

де $r_{i}$-радіус точки різальної кромки, яка розелядається, мм; $r$-радіус свердла, мм; $\omega$ кут підйому гвинтової канавки свердла, який може змінюватися в діапазоні (10-45) $; \varphi$ половина головного кута в плані, величина якого залежить від характеристик оброблюваного матеріалу.

В свою чергу кут підйому гвинтової поверхні в заданій точці різальної кромки $r_{i}$ визначається за фрормулою:

де І-крок гвинтової канавки.

$$
\tan \omega_{i}=\frac{2 \cdot \pi \cdot r_{i}}{l}
$$

Крок гвинтової канавки спірального свердла для діаметрів в діапазоні розмірів свердла Ø(5-30)мм визначається стандартом ГОСТ 22735-77.

За рекомендаціями стандартів ISO виготовляють три типи свердел:

- тип Н для оброблення крихких матеріалів з кутом підйому гвинтової поверхні $\omega=(10 \ldots 16)^{\circ}$;

- тип N для оброблення пластичних конструкційних матеріалів з кутом підйому гвинтової поверхні $\omega=(25 \ldots 35)^{\circ}$;

- тип W для оброблення кольорових матеріалів та сплавів (алюмінієві та мідні пластичні сплави) з кутом підйому $\omega=(35 \ldots 45)^{\circ}$.

На основі практичного досвіду оброблення різних конструкційних матеріалів в довідниковій літературі для вибору величини кута в плані при вершині $2 \varphi$ наводять наступні рекомендації:

- для обробленні вуглецевих конструкційних сталей $2 \varphi=(118-120)^{\circ}$;

- для оброблення корозійностійких та високоміцних сталей та сплавів $2 \varphi=(125-150)^{\circ}$;

- оброблення чавунів та бронзи $2 \varphi=(90-100)^{\circ}$;

- чавунів високої твердості $2 \varphi=(120-125)^{\circ}$;

- кольорових матеріалів та сплавів $2 \varphi=(125-140)^{\circ}$;

3 аналізу формули (1) $є$ очевидним, що передній кут залежить від кута підйому гвинтової поверхні та його величина зменшується від стрічки до поперечної різальної кромки. Задній кут $\alpha$ на головних різальних кромках змінюється в залежності від зміни переднього кута для забезпечення в певному діапазоні незмінності величини кута загострення $\beta$. Задня поверхня свердла може бути площиною, конічною поверхнею або гвинтовою. Для забезпечення сприятливих умов оброблення величину кінематичного заднього кута $\alpha_{\mathrm{K}}$, який визначають у кінематичній системі координат між продовженням розгортки гвинтової лінії траєкторії результуючого руху різання та дотичною до задньої поверхні свердла в точці, яка розглядається і визначається за формулою: 


$$
\alpha_{k}=\alpha_{\mathrm{cT}}-\eta
$$

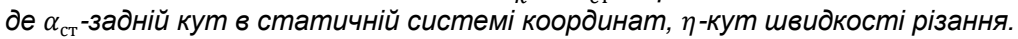

Кут швидкості різання залежить від точки різальної кромки і визначається за співвідношенням:

$$
\tan _{i}=\frac{s}{\pi \cdot d_{i}}
$$

де S-поздовжня подача інструмента, мм/об; $d_{i}$-діаметр свердла в точці, яка розелядається.

Для забезпечення ефективної величини кінематичних кутів, величина статичного заднього кута $€$ змінною і на стрічці складає $\alpha_{\text {ст }}=(9-12)^{\circ}$ а біля поперечної різальної кромки $\alpha_{\text {ст }}=(20-25)^{\circ}$.

Для ефективного оброблення отворів свердлінням необхідно визначати складові режиму різання, які включають глибину різання $h$, поздовжню подачу $S_{o}$ та швидкість різання $V$. Для їх визначення необхідно розраховувати силові навантаження на свердло, а саме момент свердління $M_{\text {св }}$ та осьову силу $P_{o}$. Технологічні довідники [2,3] для їх визначення рекомендують узагальнені степеневі моделі, які можуть бути використані для всіх видів осьового оброблення, свердління, розсвердлювання, зенкерування та розвертання:

$$
\begin{gathered}
M_{\mathrm{cB}}=C_{m} \cdot D^{z m} \cdot h^{x m} \cdot S^{y m} \cdot V^{n m} \cdot K_{m} \\
P_{o}=C_{p} \cdot D^{z p} \cdot h^{x p} \cdot S^{y p} \cdot V^{n p} \cdot K_{p}
\end{gathered}
$$

Невідомими параметрами таких моделей $€$ показники степені та коефіцієнти пропорціональності, які для конкретних умов оброблення можуть бути визначені за результатами експериментальних досліджень. На етапі проектування технологічних операцій оброблення свердлінням для визначення моменту свердління та осьової сили традиційно використовують рекомендації технологічних довідників, які, на жаль, є застарілими і значною мірою не відповідають сучасним технологічним умовам оброблення. Використання нових конструкційних матеріалів, впровадження сучасних верстатів з ЧПУ вимагає пошуку більш надійних рекомендацій для визначення силових навантажень для визначення оптимальних режимів різання.

Для аналізу особливостей процесу свердління отворів в суцільному матеріалі розділимо глибину різання на дві складові, а саме різання головною різальною кромкою разом зі стрічкою та поперечною різальною кромкою. Глибина різання для головної різальної кромки буде визначатись за формулою:

$$
h_{\Gamma}=h-h_{\Pi}=\frac{d_{c}}{2}-\left(\frac{k \cdot d_{c}}{2}\right) \cdot \cos \psi
$$

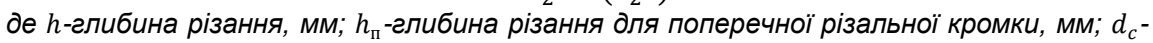
діаметр свердла, мм; $k$-коефріцієнт, який визначає співвідношення діаметру серцевини свердла та діаметра свердла; $\psi$-кут положення поперечної різальної кромки відносно головної.

Загальна довжина поперечної різальної кромки дорівнює діаметру серцевини свердла, яка залежить від конструктивних параметрів свердла і встановлюється в границях $\emptyset d_{\text {п }}=(0,20-0,25) \cdot \emptyset d_{c}$ для свердел розмірами в діапазоні $\varnothing d_{c}=(6-10)$ мм та $\emptyset d_{\Pi}=(0,13-0,16) \cdot \emptyset d_{c}$ для свердел розмірами 
$d_{c} \geq 10$ мм. Кут нахилу поперечної різальної кромки в конструкціях спіральних свердел змінюється не суттєво, є практично постійним і дорівнює $\psi=55^{\circ}$.

Головну складову сили різання $P_{z}$, яка діє на головній різальній кромці визначаємо за формулою:

$$
P_{\mathrm{Z \Gamma}}=p \cdot f_{\mathrm{\Gamma}}=p \cdot h_{\mathrm{r}} \cdot \frac{s_{o}}{2}
$$

де р-питома сила різання, яка $\epsilon$ фрізичною характеристикою конкретного оброблюваного конструкційного матеріалу.

Для заданих умов оброблення її визначають за формулою:

$$
p=p_{1.1} \cdot \frac{1-0,01 \cdot \gamma}{a^{m}}
$$

де $p_{1.1}$-одинична питома сила різання, $\frac{H}{\text { мм² }^{2}} ;$ а-товщина шару, що зрізується, мм; $m$ показник степені, який визначає вплив товщини шару, що зрізується на питому силу різання.

В довіднику [4] німецька фірма GARANT наводить величину одиничної питомої сили різання та показники степені $m$ для широкої гами конструкційних матеріалів, що забезпечує надійними вихідними даними для розрахунку моменту свердління та осьової сили різання для свердління. Момент свердління, який створюється на головних різальних кромках визначається за формулою:

$$
M_{\mathrm{cB \Gamma}}=P_{\mathrm{Z \Gamma}} \cdot \frac{l_{1 \mathrm{r}}}{2}=p \cdot h_{\mathrm{r}} \cdot \frac{S_{O}}{2} \cdot\left(\frac{k \cdot d_{c}}{2} \cdot \cos \psi+\frac{l_{\mathrm{r}}}{2}\right)
$$

де $l_{1 г}$-точка головної різальної кромки, де діє зосереджена складова сили різання $P_{z г}$.

За результатами експериментальних досліджень встановлено, що момент свердління, який діє на головних різальних кромках та стрічках свердла складає $M_{\text {свг }}=0,92 \cdot M_{\text {св }}$. Відповідно, момент свердління свердла для заданих умов оброблення дорівнює:

$$
M_{\mathrm{CB}}=1,09 \cdot M_{\mathrm{CBг}}
$$

Потужність різання для свердління розраховується за формулою:

$$
N_{\mathrm{CB}}=\left(M_{\mathrm{CB}} \cdot \frac{2 \cdot V}{d_{c}}\right) \mathrm{BT}
$$

де $M_{\mathrm{cв}}$-момент свердління, H·м; V-швидкість різання, м/c; $d_{c}$-діаметр свердла, м.

Для розрахунку осьової сили свердління використовуємо встановлені експериментальними дослідженнями співвідношення складових сили різання при обробленні лезовими інструментами, а саме $P_{x}=(0,2-0,4) \cdot P_{z}$. Для розрахунку осьової сили, яка діє на головних різальних кромках свердла приймаємо співвідношення $P_{x}=0,25 P_{z}$. Відповідно, величину осьової сили, що діє на головні різальні кромки визначаємо за формулою:

$$
P_{o \Gamma}=2 \cdot 0,25 \cdot P_{\mathrm{Z \Gamma}}=0,5 \cdot p \cdot h_{\mathrm{\Gamma}} \cdot \frac{s_{o}}{2}=0,25 \cdot p \cdot h_{\mathrm{\Gamma}} \cdot S_{o}
$$

Експериментальними дослідженнями процесів свердління встановлено, що частина осьової сили різання, що діє на головних різальних кромках складає:

$$
P_{\text {ог }}=0,4 \cdot P_{o}
$$

Відповідно до прийнятого співвідношення (13), осьову силу при обробленні свердлінням розраховуємо за співвідношенням: 


$$
P_{o}=2,5 \cdot P_{\text {ог }}
$$

Висновок. Наведений алгоритм розрахунку силових навантажень на осьовий різальний інструмент при свердлінні отворів виключає необхідність використання степеневих математичних моделей, для яких необхідно мати надійні чисельні значення показників степені та коефріцієнтів пропорціональності для заданого конструкційного матеріалу.

Для практичного використання наведеного алгоритму вихідні дані для розрахунку включають тільки величину питомої сили та показника степені, який враховує вплив товщини шару, що зрізується на питому силу різання. Такі дані наводять світові інструментальні фрірми, наприклад, SECO, Sandvik Coromant, GARANT.

\section{Список використаних джерел:}

1. Старков, В.К. (2009). Физика и оптимизация резания материалов. Москва: Машиностроение.

2. Дальский, А.М., Косилова, А.Г., Мещеряков, А.Г. \& Суслов, А.Г. (ред.). (2003). Справочник технолога-машиностроителя. (Т. 1-2); Москва: Издательство машиностроение-1.

3. Панов, А.А, Аникин, В.В. \& Бойм Н.Г. (2004). Обработка металлов резанием. Справочник технолога. Панов А. А. (ред.). Москва: Машиностроение.

4. GARANT. Справочник по обработке резанием. Изъято из www.garant-tools.com.

\section{ВИКОРИСТАННЯ ГЕНЕТИЧНИХ АЛГОРИТМІВ У МАШИННОМУ НАВЧАННI}

Тимофєєва Анастасія Євгенівна здобувач вищої освіти математичного фракультету Запорізький національний університет УКРAÏHA

Генетичний алгоритм - це евристичний алгоритм пошуку, який використовується для вирішення завдань оптимізації та моделювання шляхом послідовного підбору, комбінування і варіації шуканих параметрів з використанням механізмів, що нагадують біологічну еволюцію. Відмінною особливістю генетичного алгоритму $€$ акцент на використанні оператора «схрещування», який виробляє операцію рекомбінації рішень - кандидатів, роль якої аналогічна ролі схрещування в живій природі.

Прикладом такого завдання може служити навчання нейромережі, тобто підбору таких значень ваг, при яких досягається мінімальна помилка. При цьому в основі генетичного алгоритму лежить метод випадкового пошуку. Основним недоліком випадкового пошуку $€$ те, що нам невідомо скільки знадобиться часу для вирішення завдання. Для того, щоб уникнути таких витрат часу при виконанні завдання, застосовуються методи, що проявилися в біології. При цьому використовуються методи, відкриті при вивченні еволюції і походження видів. 
Класичний генетичний алгоритм складається з ряду найбільш важливих етапів. Фактично дані етапи можна розташувати в хронологічному порядку:

1. Ініціалізація - формування вихідної популяції;

2. Оцінка пристосованості - обчислення функції придатності для кожної особини;

3. Селекція - вибірка на основі оцінки пристосованості найбільш пристосованих хромосом, яким буде надано право участі в операціях кросинговеру;

4. Кросинговер - схрещування двох особин;

5. Мутація - навмисна штучна зміна певних генів в хромосомах особини;

6. Формування нової популяції - зниження кількості особин на основі оцінки пристосованості разом з вибором «найкращої» особини;

7. Перевірка критерію зупинки алгоритму - якщо необхідна умова пошуку досягнута - вихід, в іншому випадку - перехід до етапу № 3;

8. Витяг найкращого рішення - найкращим рішенням вважається особина з максимальним значенням функції придатності.

Оцінка пристосованості особин в популяції полягає в обчисленні значення функції придатності для кожного члена популяції.

Етап селекції передбачає вибір тих особин, генетичний матеріал яких братиме участь у формуванні наступної популяції рішень, тобто в створенні чергового покоління. Описуваний вибір проводиться відповідно до принципу природного відбору, завдяки якому максимальні шанси мають особини 3 найбільшими значеннями функції придатності.

Наступним етапом генетичного алгоритму є рекомбінація або кросинговер. Основним завданням операції кросинговеру є отримання в кінцевому підсумку найбільш функціональних ознак, які були присутні в наборах вихідних рішень.

Етап мутації передбачає зміну, яка призводить до прояву якісно нових властивостей генетичного матеріалу. Мутації відбуваються випадковим чином і викликають стрибкоподібні зміни в структурі генотипу.

Переваги генетичного алгоритму полягають у наступному:

1. Не потрібно застосування додаткових алгоритмів;

2. Ініціалізація виконується швидко і не завантажує ЕОМ;

3. Зменшено шанси потрапляння в локальний оптимум.

Недоліком можна відзначити відсутність в алгоритмі накопичених знань про налаштовані коефіцієнти. Таким чином, в результаті етапу ініціалізації є готова популяція рішень.

Найчастіше, вибір параметрів генетичного алгоритму і конкретних генетичних операторів проводиться на інтуїтивному рівні, так як поки не існує об'єктивних доказів переваги тих чи інших налаштувань і операторів. Однак, не потрібно забувати, що сама суть ГА полягає в динаміці і "м'якості" алгоритму і вироблених обчислень.

Список використаних джерел:

1. Introduction to Genetic Algorithms. Вилучено 3 https://towardsdatascience.com/introduction-togenetic-algorithms-including-example-code-e396e98d8bf3.

2. Генетический алгоритм. Вилучено з http://www.codenet.ru/progr/alg/smart/geneticalgorithms.php. 


\title{
ДОСВІД ВИКОРИСТАННЯ МОБІЛЬНИХ ТЕЛЕФОНІВ ПРИ ВИКЛАДАННІ ТЕХНІЧНОÏ МЕХАНІКИ
}

\author{
Мікаілова Маргарита Леонідівна \\ викладач-методист вищої кваліфікаційної категорії \\ Коледж ракетно-космічного машинобудування \\ Дніпровського національного університету ім.О. Гончара
}

УКРÄ̈HA

Сучасний світ так влаштований, що зараз мобільні телефони, зазвичай смартфони, планшети $є$ у кожного. В повсякденні і викладачі, і студенти широко їх використовують. Мобільний телефон, по своїй суті, $€$ досить потужним комп'ютером тому, що має безліч різноманітних функцій. Основні функції-це можливість дзвонити іншим абонентам, писати і передавати smsповідомлення, будильник, вібро сигнал, телефонну книгу, органайзер. Додаткові опції - можливість бездротового виходу в інтернет, може взаємодіяти практично з будь-якими електронними пристроями. Останні моделі мобільних телефонів додатково обладнуються сенсорними кнопками або дисплеєм. Ця опція знайшла багатьох прихильників, тому що це дуже зручно і дозволяє легко і швидко набирати тексти або знайти необхідну інформацію. Все це різноманіття необхідних опцій розташовано в зручному і зрозумілому меню. Зараз існує багато мультимедійних моделей телефонів, в яких основний акцент ставиться на першокласне відтворення музики і відео. Обов'язково такі телефони оснащуються камерами здатними створювати якісні, яскраві та чіткі фотографії.

Ще однією додатковою функцією сучасного телефону є можливість виходу в Інтернет. Дуже зручним буде наявність декількох браузерів, для більш комфортної роботи в інтернеті. Останнім віянням сучасності $€$ установка в телефон пристрою, здатного працювати в інтернеті на 3G-4G швидкостях. Це скорочує час, проведений в інтернеті даремно, просто чекаючи відкриття сторінок.

Все це розмаїття функцій говорить про те, що мобільний телефон можна використовувати не тільки як засіб спілкування і зв'язку, а й як засіб навчання. Адже ці функції відкривають нам широкі можливості в реалізації навчальної діяльності.

Використання мобільних телефонів на заняттях з Технічної механіки почалося несподівано. Почався семестр, студентам другого курсу було прочитано лекції і видано розрахунково-графічні завдання для самостійного розв язку, студентам третього курсу було видано завдання на курсове проектування, складено графік консультацій, призначено дати захисту курсового, і т.д. Студенти, як студенти, поволі виконували задане, іноді з'являючись на консультації, мовляв, ще $є$ час і все встигнеться. Аж раптом сімейні обставини вимусили мене взяти відпустку на кілька тижнів і поїхати на Кавказ, де занедужала свекруха. Написала про це своїм студентам у групи в VIBERi і додала, що графік здачі завдань залишається незмінним, незважаючи 
на мою відсутність. I ще я запропонувала писати мені y VIBER, якщо будуть проблеми в розрахунках. I далі почалися дива... Студенти почали надсилати фотографої чернеток 3 розрахунково-графічними завданнями і просити підказати в якому рівнянні $€$ помилка, що зроблено невірно. Писали в різний час: хто пізно увечері, хто вдень. Я також відповідала, коли вдавалося відірватися від справ. Відповідати було не важко, адже в телефронах $є$ функція голосового повідомлення. Все робилося досить просто. Іноді, коли виникали питання щодо курсового проекту, робила потрібні ескізи, фотографувала і надсилала адресату. Коли виникли у багатьох студентів проблеми з одним і тим же розділом курсового проекту я записала на відео детальний коментар до цього розділу, розмістила в YouTube i надіслала студентам посилання. Потім я зробила записи розбору прикладів розв'язку розрахунково-графрічних завдань (РГЗ). І отримала позитивні відгуки моїх студентів. Кожного дня я отримувала повідомлення про нові й нові виконані розділи курсового проекту $і$ зроблені креслення, про зроблені РГЗ. Дехто з студентів писав, що готовий захищати розрахунки, коли вже я повернуся? Це питання спонукало мене вдатися до використання чудового інтернет-інструменту оцінювання знань студентів - Quizizz. Я давно про нього чула, але працювала за звичним порядком - тести на папері, потім їх перевірка вручну за кодами. Але життя внесло корективи і не хотілося відкладати всю роботу на час мого повернення. Та й студентам нетерпілося швидше захистити розраховані завдання (їх на той час було вже чотири! видано). Сервис Quizizz зрозумілий і легкий у використанні. Довелося витратити час, щоб створити тести по різним темам для захисту розрахунково-графрічних завдань на своєму комп'ютері. Коли було все готово. Я надіслала в студентські групи у VIBERi посилання на Quizizz з пропозицією до бажаючих захистити свої розрахунки, відповідаючи на питання тесту зі своїх мобільних пристроїв. Студенти мали можливість приєднатися до вікторини, перейшовши за посиланням і ввівши код, присвоєний грі в будь-який зручний для них час протягом доби (цей термін я встановила, надсилаючи тести в якості домашнього завдання).

Всі студенти отримали однакові завдання, але кожен з них на своєму мобільному пристрої бачив випадкову послідовність питань і працював 3 тестом у властивому для себе темпі. На дисплеї студента з'являлося все питання із зображенням, яке при бажанні можна було збільшити, а також символи відповідей. Бали нараховувалися за правильні відповіді. Я, знаходячись за дві тисячі кілометрів від коледжу, мала можливість відстежувати роботу кожного студента. Бачила, коли хто приєднався до роботи з тестом і отримувала повну картину роботи групи. Сервис Quizizz дозволяє зберегти результати опитування в таблиці ехcel, в якій фіксуються всі дані по учасників - час, витрачений на відповіді, кількість правильних-неправильних відповідей. Мені залишалося результати опитування перевести в оцінку. Мої студенти також мали можливість відразу бачити результати тестування екрані свого гаджета і зробити висновок чи відбувся захист роботи чи треба краще підготуватися.

Так пройшли два тижні моєї відсутності в коледжі. Але я повернулася 3 повною відсутністю почуття форс-мажору з приводу накопичених незданих РГЗ та гальмування графріку виконання курсового проекту. 
Я виставила отримані студентами дистанційно оцінки в журнал успішності та в студентські бланки з оформленими РГЗ. Коли оцінки було проставлено, мене чекав сюрприз: такого прориву ще не було - 1-2 боржники! В групах 3 курсовим проектом також не було суттєвого відставання від графіку здачі розділів і креслень. Висновок напрошувався лише один: мобільні телефони стають невід'ємною частиною системи навчання та розвитку. Вони не витісняють традиційні методи і засоби навчання, а інтегруючись 3 ними, відкривають всі нові можливості підвищення ефективності педагогічного процесу. Мобільні телефони допомагають забезпечити великий обсяг самостійної роботи студента, підвищують інтерес до навчальної діяльності, підвищують самоорганізацію і відповідальність, вміння ставити перед собою цілі і організовувати свою діяльність. А це в свою чергу благотворно позначається на знаннях студентів. Навчання стає гнучким, не пов'язаним жорстким навчальним планом і обов'язковими аудиторними заходами, що особливо важливо для сучасних студентів, котрі намагаються і навчатися i заробляти «власні» гроші після занять.

\section{ДЕРЕВО ВІДМОВ - ІНСТРУМЕНТАРІЙ ОЦІНЮВАННЯ НАДІЙНОСТІ ТЕХНОЛОГІЧНИХ СИСТЕМ}

Рубанніков Михайло Анатолійович здобувач вищої освіти факультету електроніки та комп'ютерної техніки Дніпровський державний технічний університет

Науковий керівник: Ялова Катерина Миколаївна канд. техн. наук, доцент, доцент кафедри програмного забезпечення систем Дніпровський державний технічний університет УKPÄ̈HA

Технологічна система - це сукупність фрункціонально пов'язаних засобів технологічного оснащення, предметів виробництва, технологічних процесів або операцій. Найважливішою властивістю системи $є$ надійність їі функціонування, заснована на безперебійності роботи з мінімізацією виникнення небажаних подій [1]. Завдання зниження ризику аварій і відмов технологічних об'єктів є одним із пріоритетних завдань управління промисловою безпекою. Багатофакторний аналіз ризиків виникнення аварійних ситуацій ускладняється недостатністю обсягу і невизначеністю вхідної інформації. До методів оцінювання надійності технологічних систем відносяться методи теорії випадкових процесів та експертних оцінок, евристичного прогнозування, логіко-імовірнісні, асимптотичні, аналітикостатистичні методи.

Дерево відмов (fault tree) - це графічне представлення причинних взаємозв'язків, отриманих у результаті відстеження небезпечних станів системи в зворотному порядку (від кінцевої небажаної події до початкових, із метою встановлення причини її виникнення) [2]. Дерево відмов лежить в основі 
логіко-ймовірнісного аналізу надійності системи. Для побудови дерева відмов застосовуються певні поняття, правила і графічні нотації. Основні елементи дерева відмов - це події системи, які впливають на переході між ії станами; логічні операції «ТА» і «АБО» для формування ланцюга технологічних операцій і подій системи. Математично структуру дерева відмов описують засобами алгебри логіки. Булева логіка дозволяє врахувати лише два стани: «робочий» і «неробочий», це ускладнює врахування часткової відмови системи із складними контурами регулювання, що $€$ суттєвим недоліком дерева відмов.

Алгоритм побудови дерева відмов для оцінювання надійності технологічної системи складається з наступних етапів:

1. Визначення всіх подій технологічної системи і рівня ії деталізації. Всі події розподіляються на групи, де виділяється головна подія, до якої, у різних комбінаціях, призводять всі події групи, і яку необхідно попередити. Встановлюються головна та всі можливі небажані події в системі.

2. Формування ланцюга технологічних подій: використовуючи логічні операції, для кожної події описуються вхідні та результуючі події.

3. Створення графрічного відображення дерева відмов.

4. Виконання кількісного аналізу з розрахунком ймовірностей подій. Для цього для кожної події встановлюється відносна частота її появи. Ймовірності виникнення складних подій розраховуються за формулами, які можуть містити додавання та добуток ймовірностей з урахування їх логічних взаємозв'язків. У кінцевому рахунку для всіх небажаних подій системи розраховуються ймовірності їх виникнення.

Висновки. Застосування дерева відмов забезпечує ретельний аналіз причин відмов та аварійних ситуацій, дозволяє розглядати альтернативні заходи, націлені на зменшення ймовірності виникнення головної небажаної події. Цінність дерева відмов полягає у можливості наочного відображення ненадійних місць системи і проведення кількісного аналізу надійності системи.

\section{Список використаних джерел:}

1. Шарай, В.А., Бурангулова, О.С. \& Андриуца, М.В. (2011). Мониторинг состояния надежности и безопасности структурно-сложных систем на основе логико-числовых моделей. Известия ЮФУ. (2), 35-49.

2. Серебровский, А. Н., Ситниченко, Л. П. \& Пилипенко, В. Г. (2009). Алгоритм формирования и минимизации логического представления дерева отказов. Математичні машини $i$ системи. (1), 165-172. 


\section{ЗНЕШУМЛЕННЯ СУПУТНИКОВИХ ЗНІМКІВ І3 ВИКОРИСТАННЯ ІНТЕРПОЛЯЦІЇ ЛАНЧОСА}

Шиш Микола Миколайович

здобувач вищої освіти факультету фізики, електроніки та комп'ютерних систем Дніпровський національний університет імені Олеся Гончара

Науковий керівник: Долгов Валерій Михайлович канд. ф.-м. наук, доцент кафедри комп'ютерних наук та інформаційних технологій Дніпровський національний університет імені Олеся Гончара

УКРÄ̈HA

Моніторинг земельних ділянок за допомогою супутникових знімків може використовуватися для вирішення багатьох проблем в сільськогосподарській сфрері. Використання знімків для задач розпізнавання і виділення об'єктів дозволяє визначати реальні контури полів і корегувати їх межі на картах при необхідності, виявляти які сільськогосподарські культури були посаджені.

При використанні часових рядів супутникових знімків можна проводити аналітику якості врожаю, визначати стадії росту рослин, розпізнавати захворювання. Актуальна інформація щодо стану полів після стихійних лих може використовуватися страховими агентствами при роботі зі страхуванням сільськогосподарських угідь. Також при порівнянні знімків за певний діапазон дат можна визначати місце та інтенсивність вирубки лісу, розорення ґрунтів при видобуткові бурштину, чи шкоди від лісових пожеж [1].

При обробці супутникових знімків які мають високу роздільну здатність постає проблема зашумлення зображень, оскільки в такому маштабі шум може може значно вплинути на розпізнавання і зміщення навіть на пару пікселів може бути важливим. Тому перед подальшою обробкою знімків спочатку потрібно провести процедуру знешумлення.

В результаті процедури знешумлення ми хочемо отримати зображення в яких зменшений рівень шуму і при цьому збережені контури наявні на вхідних знімках. При використанні цифррових фільтрів часто виникає проблема затирання контурів. В даній роботі використовується реалізація алгоритму адаптивного фільтру, при якому інтенсивність пікселів на виході залишається близькою до вхідної. Залучаючи інтерполяційні поліноми Ланчоса ми обираємо такий поліном з такою областю визначення в околі заданого пікселя при якому прогноз в заданому поліномі найкраще наближається до реального значення в цьому пікселі.

Для кожного пікселя береться 8 векторів (прямі що проходять крізь центральний піксель з кроком 22.5 градусів) і з 6 сусідніх пікселів і на їх основі обчислюється метрика $L$ за якою визначається який вектор може дати кращий результат. Потім на основі цих пікселів обчислюється нове значення пікселя. В даному випадку використовується 3 фільтри для обчислення нового значення пікселя: середній, медіанний і фільтр Ланчоса. Метрика вираховується як:

$$
M=\left|S_{-2}-S_{-1}\right|+\left|\mathrm{S}_{-1}-\mathrm{S}_{0}\right|+\left|\mathrm{S}_{1}-\mathrm{S}_{2}\right|+\left|\mathrm{S}_{2}-\mathrm{S}_{3}\right|
$$

де $S_{-2}, S_{-1}, S_{0} i S_{1}, S_{2}, S_{3}$ значення пікселів з різних боків від поточного. 
128 - Problèmes et perspectives d'introduction de la recherche scientifique innovante $\bullet$ Volume 2

Для перевірки роботи алгоритму було взято вирізане зображення полів із супутникового знімку(рис.1) і зашумлене 3 видами шумів: salt\&pepper, gaussian, speckle. Також алгоритм застосовувався в 2 варіантах: безпосередньо до растрової матриці вхідного зображення(рис.2) і до HL, LH і НН каналів його вейвлет-перетворення(рис.3). Одна з переваг останнього підходу в тому, що він дозволяє знешумити зображення і без помітного погіршення якості вихідного зображення [2].

Original Image

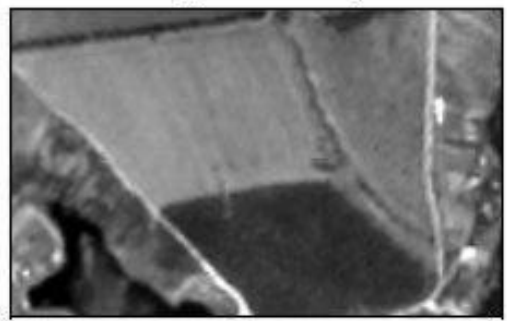

Canny edge detection

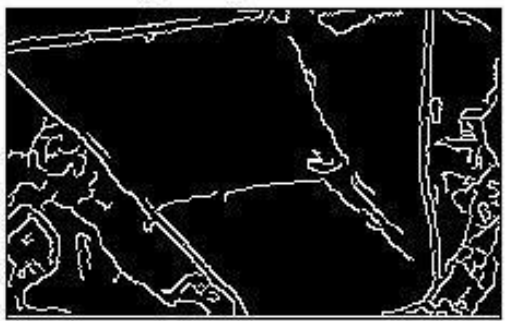

Рис. 1. Приклад оригінального незашумленого зображення та виділення контурів за допомогою детекції Кенні
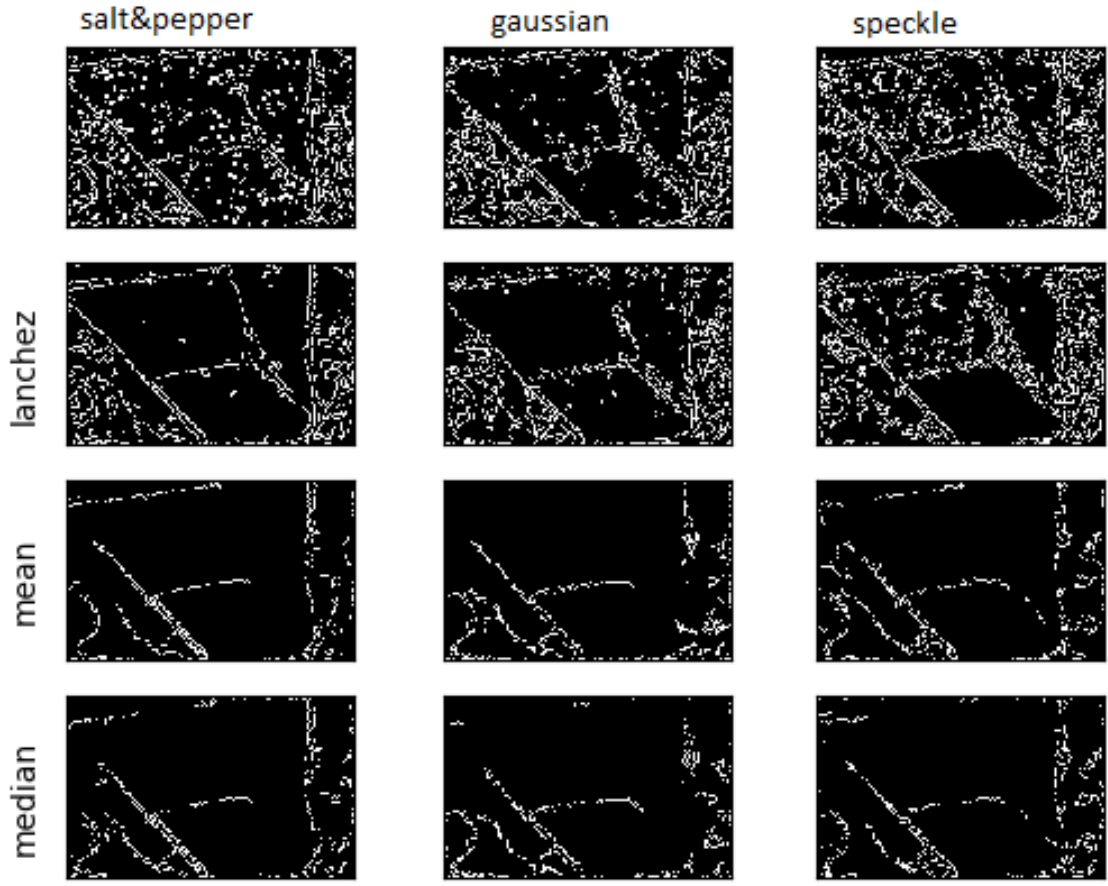

Рис. 2. Приклади детекції Кенні знешумлених зображень при роботі із растровою матрицею 
salt\&pepper
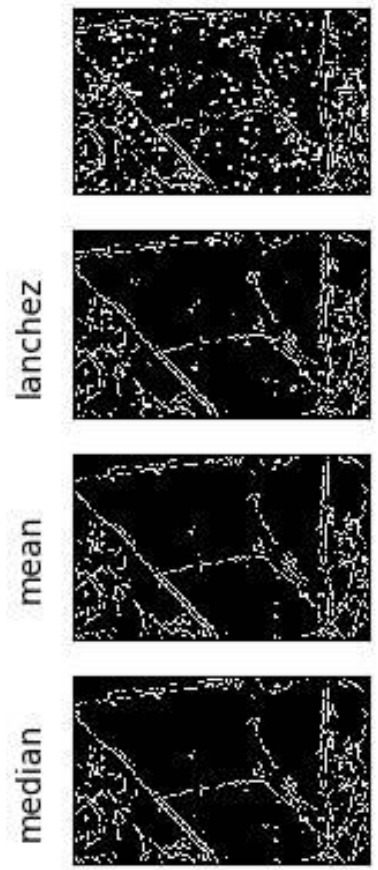
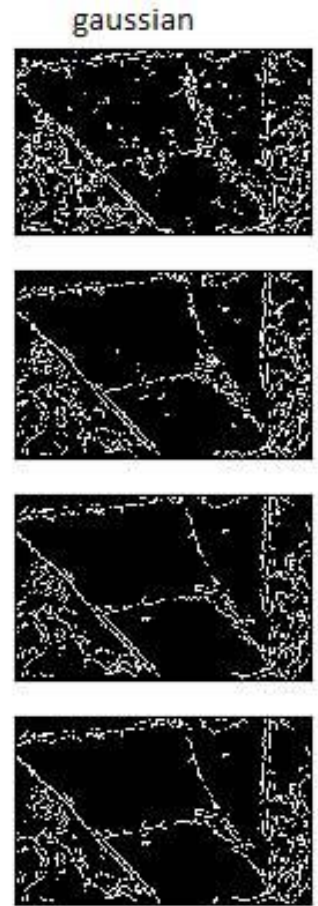

speckle
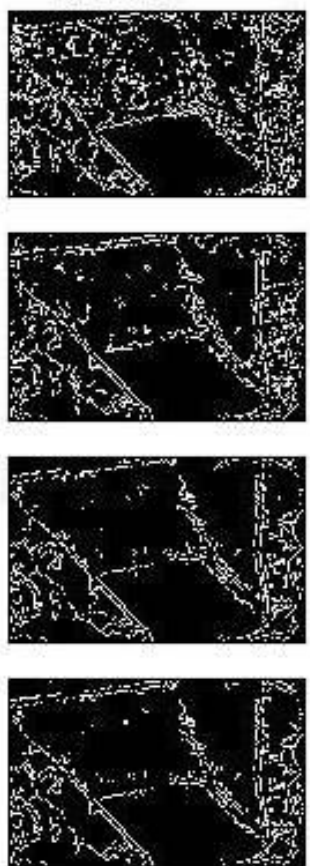

Рис. 3. Приклади детекції Кенні знешумлених зображень при роботі із каналами вейвлет-перетворення

Як видно з рис.2 в порівнянні з результатами рис.3 підхід із використанням вейвлет-перетворення показав кращі результати ніж при роботі безпосередньо із растровою матрицею. В другому випадку, при використанні фільтру Ланчоса шум прибирається добре для salt-pepper, але гірше для інших видів шумів, середній та медіанний фільтр добре усувають шум але разом 3 тим зменшують інтенсивність пікселів контурів і вони гірше розпізнаються.

В підсумкові можна сказати що підхід із використанням вейвлетперетворення працює краще для знешумлення зі збереженням контурів i медіанний фільтр показує трохи кращі результати для тестових зображень 3 поміж інших, але при цьому все рівно наявні залишки шуму.

\section{Список використаних джерел:}

1. Куссуль, Н.М., Скакун, С.В. \& Шелестов А. Ю.. (2014). Геопросторовий аналіз ризиків стихійних лих. К.: Наукова думка.

2. Narayan Bhosale Image Denoising based on Wavelet for Satellite Imagery: A review. Вилучено 3 https://www.researchgate.net/publication/304326042_Image_Denoising_based_on_Wavelet_for_ Satellite_Imagery_A_review. 


\section{ІННОВАЦІЙНІ ТЕНДЕНЦІЇ РОЗВИТКУ УСТАТКУВАННЯ В ЗАКЛАДАХ ГОТЕЛЬНО-РЕСТОРАННОГО ГОСПОДАРСТВА}

Будженко Альона Юріївна

Вінницький торговельно-економічний інститут КНТЕУ

Іваніщева О.А.

старший викладач

Вінницький торговельно-економічний інститут КНТЕУ

УКРАÏHA

Для будь-якого закладу готельно-ресторанного господарства основним завданням $є$ утримання клієнта. Для досягнення цієї мети заклади проводять безліч різних акцій, удосконалюють інтер'єр та обслуговування, а особливо вводять інноваційні тенденції в устаткування. Вони не тільки приваблюють клієнтів, а й спрощують роботу персоналу.

Кожного дня власники готелів та ресторанів шукають та впроваджують тренди для устаткування, щоб вижити серед жорсткої конкуренції. Технічна досконалість проявляється від традиційних машин ручного використання до повної автоматизації технологічного процесу [1].

Найбільшого удосконалення зазнали всім відомі теплові апарати - плити. Вони оснащенні жарильною поверхнею, яка виконана 3 композитних матеріалів. Це дозволяє використовувати різні температури для приготування різноманітних страв одночасно. Дані плити можуть підтримувати температуру від -20 до -10 градусів С.

На даний момент, розробляється впровадження гелевих холодильників. Така машина буде охолоджувати продукти за допомогою спеціальних біороботів, які функціонують в гелевій субстанції. Для того щоб охолодити продукт, вам потрібно помістити його в гель і через спеціальний телефон зазначити потрібно температуру. Така інновація дозволяє підбирати різну температуру для кожного продукту. Холодильник майже не використовую електроенергію.

Ще одним проривом в удосконаленні устаткування $€$ пароконвектомати. Нещодавно компанія Rational презентувала розробку апарату Self Cooking Center 5 Senses. Вона особлива тим, що може розпізнавати колір, розмір та кількість продуктів, також обладнання індивідуально підбирає температуру та вологість для кожної страви. Пароконвектомат продумує приготування їжі від початку і до кінця, запам'ятовує всі зазначені команди та побажання кухаря. Це надзвичайно прискорює приготування страв, а термін окупності, за розрахунками, не перевищує 1 рік.

Доволі популярним в сфрері ресторанного бізнесу $\epsilon$ впровадження маринаторів. Дане устаткування скорочує роботу працівників в 50 разів. Адже за допомогою панелі управління ви можете зазначити потрібну температуру та час маринування.

Каво-машини також займають важливе місце в підвищенні рейтингу закладів. Адже тепер вони автоматично очищаються після приготування будь- 
якого напою, а технічний рівень машини дозволяє їй визначити, чи смачно був приготовлений лате.

За кордоном набуває популярності така інновація, як інтерактивні сенсорні столи, барні стійки та меню. Для оформлення замовлень вам не потрібен офріціант, адже ви можете спокійно ознайомитись з меню і зробити замовлення, а також внести в нього будь-які корективи та побажання. Інтерактивні барні стійки дозволяють клієнтам замовляти напої і залишати відгуки про обслуговування та якість приготування страв [3].

В готельному бізнесі власники облаштовують будівлю новітніми панелями Grow, які контролюють температуру та вологість в приміщенні. Така новітня технологія надзвичайно проста в керуванні, адже всю систему можна підтримувати за допомогою гаджета.

Важливим також є забезпечення затишного відпочинку для гостя. Для цього біля номеру встановили спеціальні датчики, які повідомляють персонал про наявність клієнта в номері. Це дозволяє покоївкам не турбувати вас під час відпочинку, адже вони просто можуть просканувати ситуацію в номері.

В Америці вже за обов'язкове надають гостеві IPad, який під'єднаний до інформаційної бази підприємства. Він несе в собі всі важливі повідомлення, акції та карти. Також він контролює температуру в номері та допомагає вам зробити замовлення.

Наприклад готель Element Hotels в Америці створив для гостей автоматичний відпочинок у всьому. Навіть коли ви приймаєте душ, спеціальна система контролю дозволяє витрачати менше води. А дзеркала 3 інтерактивною поверхнею допомагають вам дізнатись потрібну інформацію і ніколи не запотівають.

Ще один готель, який йменує себе «Готель електронного мистецтва» став популярний через свій інноваційний дизайн. Він представлений відео інсталяцією, яку спроектував Рафаель Лозано-Хаммер. Навколо інсталяції побудований весь дизайн будівлі [2].

Інноваційне устаткування все більше й більше впроваджується в заклади готельно-ресторанної індустрії. І це $є$ надзвичайно корисно, оскільки дані технології спрощують роботу працівників та допомагають влаштувати якісний відпочинок гостеві.

\section{Список використаних джерел:}

1. Принципи впровадження інноваційних технологій в готелях та їх переваги. Вилучено $з$ http://tourlib.net/statti_ukr/sanenko.htm.

2. ТОП-10 НАЙБІЛЬШ ВИСОКОТЕХНОЛОГІЧНИХ ГОТЕЛІВ СВІТУ. ВиЛУчено 3 https://tsn.ua/nauka_it/top-10-naibilsh-visokotehnologichnih-goteliv-svitu.html.

3. Туристична бібліотека. Вилучено 3 http://tourlib.net/statti_ukr/tarasenko.htm. 


\title{
МОДЕЛИРОВАНИЕ РАБОТЫ ШПАНГОУТНОЙ ВАННЫ С ДОПОЛНИТЕЛЬНЫМ ТЕПЛОИЗОЛЯТОРОМ
}

\author{
Мелешко Ирина Анатольевна \\ аспирант кафедры Электропривода и автоматизации промышленных установок \\ Национальный университет «Запорожская политехника» \\ Назарова Елена Сергеевна \\ кандидат технических наук, доцент, доцент кафедры \\ Электропривода и автоматизации промышленных установок \\ Национальный университет «Запорожская политехника»
}

УКРАИНА

Для повышения технико-экономических показателей и увеличения срока службы электролизёра, необходимо соблюдать технологию электролиза, а также учитывать физико-химические свойства процесса электролиза расплавленных солей и конструкционные элементы электролизера, одним из которых является футеровка [1]. Шпангоутная конструкция катодного кожуха имеет ряд преимуществ, так как характеризуется упрощенным монтажом и высокой ремонтопригодностью [2].

При построении модели электролизера, рассмотрим возможность применения теплоизоляционного элемента, в качестве которого принимается вермикулитовая плита, толщиной 130 мм на днище катодного кожуха шпангоутного типа.

Для расчётной модели электролизёра приняты следующие параметры:

Конструкция катодного узла: 8-ми оконный катодный кожух шпангоутного типа; катодный стержень шириной 115 мм и высотой 180 мм; размер подового угольного блока $450 * 480 * 3000$ мм; боковой угольный блок - прямоугольный размерами 550*600*200мм; содержание графита в подовом блоке - $50 \%$; глубина шихты электролизёра - 400 мм; тип теплоизолятора - вермикулит; расположение теплоизолятора - днище катодного кожуха, боковая поверхность катодного кожуха.

Основные технологические параметры: уровень расплава жидкого алюминия - 22см; уровень расплава электролита - $16 \mathrm{cm;} \mathrm{криолитовое}$ отношение - 2,25; содержание $\mathrm{CaF}_{2}-7 \%$; содержание $\mathrm{MgF}_{2}-1,5-2,0 \%$, перегрев электролита $1-5 \circ \mathrm{C}$.

Конструкция футеровки расчетной модели электролизёра.

В фрутеровке торцевых и продольных сторон модели электролизёра проведены следующие изменения: трапециевидные боковые угольные блоки по торцевым сторонам электролизёра заменены на прямоугольные, размерами $550^{*} 600^{\star} 200$ мм; по торцевым сторонам электролизёра применена дополнительная углеграфитовая вставка размерами 200*130*550 мм; проведено дополнительное утепление боковых сторон шпангоутного кожуха на высоту 180 мм от верхней поверхности подового блока. 


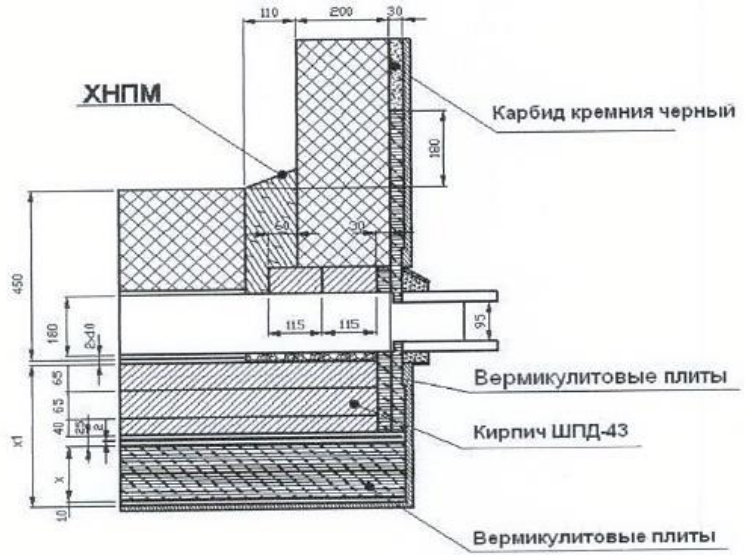

Рис.1 Схема катодной футеровки продольной стороны электролизёра

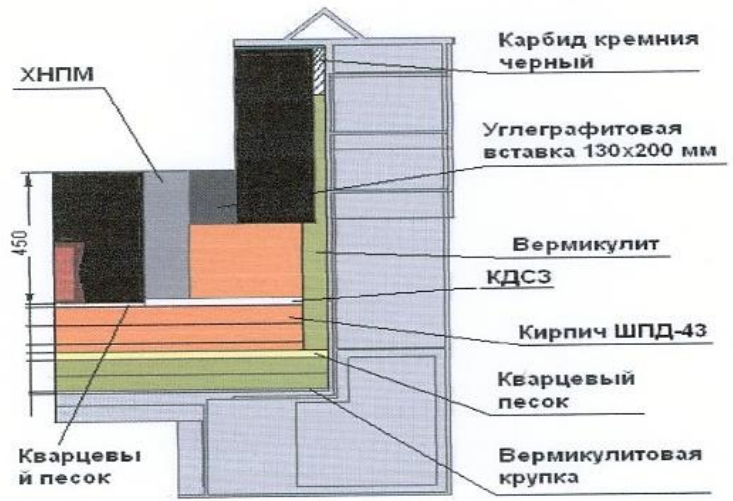

Рис.2 Схема катодной футеровки торцевой стороны электролизёра

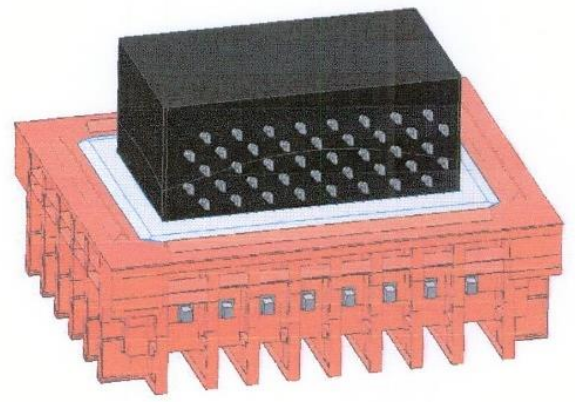

Рис.3 Модель электролизёра 
134 - Problèmes et perspectives d'introduction de la recherche scientifique innovante $\bullet$ Volume 2

Расчётная температура начала кристаллизации составила 924,4C, расчётная температура процесса электролиза с учётом заданного перегрева $(15 \circ \mathrm{C})$ составляет 939,4 ॰C. Низкая температура процесса электролиза уменьшает потери тепла конструктивными элементами расчётного электролиза. Расчётное удельное сопротивление составляет 0.49 Омсм

Моделирование температурных полей расчётного электролизёра.

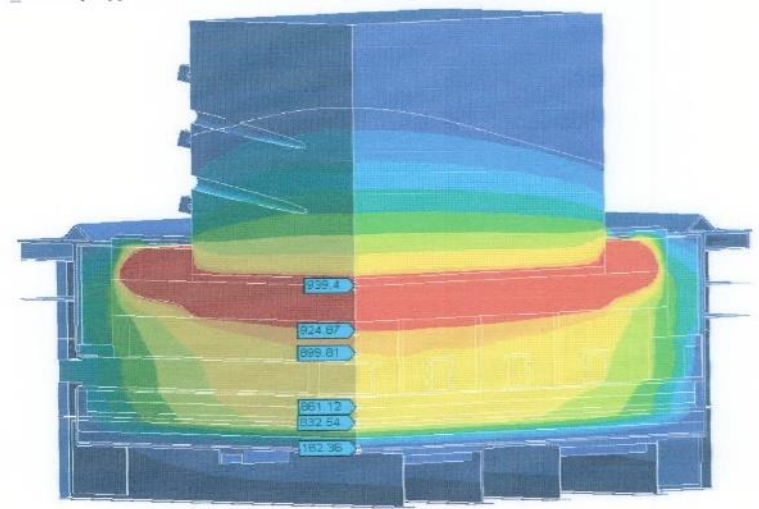

\section{Рис.4 Температуры в слоях катодной футеровки при толщине теплоизолятора 130 мм}

Критерий оптимальности работы электролизера, применяемый при моделировании в качестве основного параметра - нахождения изотермы температур 820-860॰C в слое огнеупорного кирпича при толщине вермикулитовой плиты 130 мм в качестве теплоизолятора на днище кожуха. В таблице 1 представлены значения температур в слое огнеупорного кирпича и на днище кожуха при толщине применяемого теплоизолятора 130 мм.

Таблица 1

Значения температур

\begin{tabular}{|c|c|c|c|c|c|c|}
\hline $\begin{array}{c}\text { Тип } \\
\text { изолятора }\end{array}$ & $\begin{array}{c}\text { Толщина } \\
\text { слоя } \\
\text { теплоизо- } \\
\text { лятора, мм }\end{array}$ & $\begin{array}{c}\text { Температура } \\
\text { под слоем } \\
\text { огнеупорного } \\
\text { кирпича, ॰C }\end{array}$ & $\begin{array}{c}\text { Температу } \\
\text { ра на } \\
\text { днище } \\
\text { кожуха, }{ }^{\circ} \mathrm{C}\end{array}$ & $\begin{array}{l}\text { Тепловой } \\
\text { поток } \\
\text { через } \\
\text { днище , } \\
\text { ккал } / \mathrm{M}^{2} \cdot \mathrm{c}\end{array}$ & $\begin{array}{c}\text { Длина } \\
\text { подовой } \\
\text { настыли от } \\
\text { бокового } \\
\text { блока по } \\
\text { торцевой } \\
\text { стороне, см }\end{array}$ & $\begin{array}{c}\text { Длина подовой } \\
\text { настыли от } \\
\text { бокового блока } \\
\text { по продольной } \\
\text { стороне, см }\end{array}$ \\
\hline ПВНТ-600 & 130 & 837,83 & 182,83 & 850 & 45,1 & 57,1 \\
\hline
\end{tabular}

[авторська розробка]

Таблица 2

Энергобаланс расчётной модели при толщине теплоизолятора на днище кожуха 130 мм

\begin{tabular}{|c|c|c|c|}
\hline $\begin{array}{c}\text { Толщина слоя } \\
\text { теплоизолятора, мм }\end{array}$ & $\begin{array}{c}\text { Удельный расход } \\
\text { электроэнергии, } \\
\text { кВт*ч/т }\end{array}$ & $\begin{array}{c}\text { Энергетический КПД, } \\
\%\end{array}$ & $\begin{array}{c}\text { Рабочее } \\
\text { напряжение, В }\end{array}$ \\
\hline 130 & 15390 & 52,94 & 4,583 \\
\hline
\end{tabular}

[авторська розробка] 
Выводы: В результате моделирования установлена взаимосвязь толщины теплоизолятора в конструкционных элементах шпангоутных ванн и длины подовой настыли при применении дополнительного теплоизолятора. Установка вермикулитовой плиты толщиной 130 мм приводит к уменьшению длины подовой настыли под проекцией анода до продольных сторон электролизера на 4 см, до торцевых сторон электролизера на 8,5см. Данное технологическое улучшение снижает удельный расход электроэнергии с $15434 \mathrm{\kappa BT}^{*} 4 / \mathrm{T}$ до $15390 \mathrm{\kappa Вт} 4 / \mathrm{T}$. В технико-экономических показателях прогнозируется снижение потребления электроэнергии на 44 кВт*ч на каждой тонне расплава.

\section{Список используемых источников:}

1. Ермаков, А. В. (2006). Катодные кожуха шпангоутного типа для серийных электролизёров. Весник ИрГТУ (4), 115-116

2. Курохтин, А.Н. (1973). Электролизёры с боковым токоподводом и их обслуживание. Москва: Металлургия. 


\section{$\Lambda \mathrm{O} \mathrm{O} \mathrm{O}$}

COLLECTION DE PAPIERS SCIENTIFIQUES

\section{SUR LES MATÉRIAUX DE LA CONFÉRENCE SCIENTIFIQUE ET PRATIQUE INTERNATIONALE «PROBLÈMES ET PERSPECTIVES D'INTRODUCTION DE LA RECHERCHE SCIENTIFIQUE INNOVANTE» 20 novembre 2019 • Bruxelles, Belgique}

\section{VOLUME 2}

Ukrainien, russe, français et anglais

Les matériaux sont imprimés dans le texte de l'auteur Le comité organisateur ne partage pas toujours la position des auteurs Pour l'exactitude de ce matériel, les auteurs portent la responsabilité

Signé pour impression le 29.11.2019. Format $60 \times 84 / 16$.

Papier offset. Arial type. Impression numérique

Feuilles imprimées conditionnées 8,02.

Un tirage de 100 exemplaires.

Imprimé à partir de la mise en page originale finie.

Coordonnées du comité d'organisation:

21037, Ukraine, Vinnytsia, st. Zodchih, 18, bureau 81

Plateforme scientifique européenne

Téléphones: +38 098 1948380; +38098 1956755

E-mail: info@ukrlogos.in.ua

www.ukrlogos.in.ua | www.ojs.ukrlogos.in.ua 